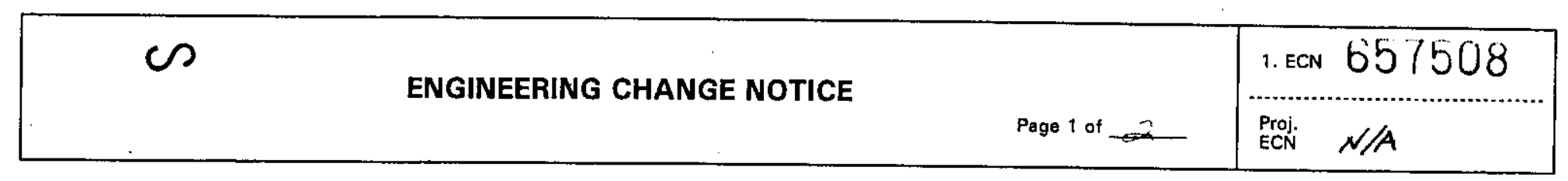

\begin{tabular}{|c|c|c|c|c|c|}
\hline \multirow{3}{*}{$\begin{array}{l}\text { 2. ECN Category (mark one) } \\
\text { Supplemental } \\
\text { Direct Revision } \\
\text { Change ECN } \\
\text { Temporary } \\
\text { Standby } \\
\text { Supersedure } \\
\text { Cancel } N \text { Noid }\end{array}$} & \multicolumn{3}{|c|}{$\begin{array}{l}\text { 3. Originator's Name, Organization, MSIN, and Telephone No. } \\
\text { CE Wills, WRAP Engineering, } \\
\mathrm{T} 4-52,373-9844\end{array}$} & $\begin{array}{l}\text { 4. USQ Required? } \\
\text { Yes } \bigcirc \text { No }\end{array}$ & $\begin{array}{l}\text { 5. Date } \\
03 / 07 / 00\end{array}$ \\
\hline & $\begin{array}{l}\text { 6. Project Title/No. Work } \\
\text { TRU Waste/101692 }\end{array}$ & $\begin{array}{l}\text { der No. } \\
\text { AJ70 }\end{array}$ & 7. Bldg./Sys./F & c. No. & $\begin{array}{c}\text { 8. Approval Designator } \\
\mathrm{Q}\end{array}$ \\
\hline & $\begin{array}{l}\text { 9. Document Numbers Ch } \\
\text { sheet no. and rev.) } \\
\text { HNF-5148, Rev. } 1\end{array}$ & nged by this ECN (includes & $\begin{array}{l}\text { 10. Related EC } \\
\qquad \mathrm{N} / \mathrm{A}\end{array}$ & $\mathrm{N} \mathrm{No(s).}$ & $\begin{array}{l}\text { 11. Related PO No. } \\
\text { N/A }\end{array}$ \\
\hline $\begin{array}{l}\text { 12a. Modification Work } \\
\text { Yes (fill out Blk. 12b) } \\
\text { No (NA Blks. 12b, } \\
\text { (2c, 12d) }\end{array}$ & $\begin{array}{l}\text { 12b. Work Package No. } \\
\qquad \text { N/A }\end{array}$ & $\begin{array}{l}\text { 12c. Modification Work Cor } \\
\mathrm{N} / \mathrm{A} \\
\text { Design Authority/Cog. En } \\
\text { Date }\end{array}$ & ted & $\begin{array}{l}\text { 12d. Restored } \\
\text { or Standb } \\
\text { Design Autho }\end{array}$ & $\begin{array}{l}\text { to Original Condition (Temp. } \\
\text { y ECNs only) } \\
\mathrm{N} / \mathrm{A} \\
\text { rity/Cog. Engineer Signature \& } \\
\text { Date }\end{array}$ \\
\hline
\end{tabular}

This document is being revised to reflect the recalculation of transmission factors required due to transmission source linkage maintenance.

\begin{tabular}{|lr|l}
\hline 14a. Justification (mark one) & 14b. Justification Details \\
Criteria Change & D & Design verification not required \\
Design Improvement & $\bigcirc$ & USQ WRP-054 \\
Environmental & $\bigcirc$ & WS \\
Facility Deactivation & $\bigcirc$ & \\
As-Found & $\bigcirc$ & \\
Facilitate Const. & $\bigcirc$ & \\
Const. Error/Omission & $\bigcirc$ & \\
Design Error/Omission & $\bigcirc$ & \\
\hline
\end{tabular}

15. Distribution (include name, MSIN, and no. of copies)

See attached distribution sheet

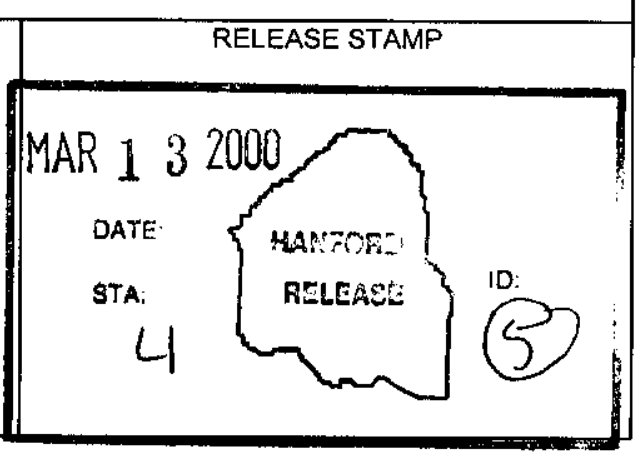

A.7900-013-1 
ENGINEERING CHANGE NOTICE

16. Design Verification Required
Yes
( ) No

17. Cost Impact

ENGINEERING

Additional $\bigcirc \$ \underline{N} / \mathrm{A}$

Savings

$\$ \underline{N} / \mathrm{A}$

Additional

CONSTRUCTION

\begin{tabular}{l|l} 
Page 2 of 2 & ECN- 657508
\end{tabular}

18. Schedule Impact (days)

$\$ \underline{N} / \mathrm{A}$

$\$ \mathrm{~N} / \mathrm{A}$

- Improvement $O \frac{N / A}{}$

19. Change Impact Review: Indicate the related documents (other than the engineering documents identified on Side 1) that will be affected by the change described in Block 13. Enter the affected document number in Block 20.

\begin{tabular}{|c|c|c|}
\hline SDD/DD & $\square$ & Seismic/Stress Analysis \\
\hline Functional Design Criteria & 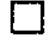 & Stress/Design Report \\
\hline Operating Specification & [ & Interface Control Drawing \\
\hline Criticality Specification & 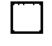 & Calibration Procedure \\
\hline Conceptual Design Report & L & Installation Procedure \\
\hline Equipment Spec. & 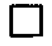 & Maintenance Procedure \\
\hline Const. Spec. & 4 & Engineering Procedure \\
\hline Procurement Spec. & [ & Operating Instruction \\
\hline Vendor Information & [ & Operating Procedure \\
\hline OM Manual & L & Operational Safety Requirement \\
\hline FSAR/SAR & 4 & IEFD Drawing \\
\hline Safety Equipment List & [ & Cell Arrangement Drawing \\
\hline Radiation Work Perrnit & - & Essential Material Specification \\
\hline Environmental Impact Statement & L & Fac. Proc. Samp. Schedule \\
\hline Environmental Report & $\square$ & Inspection Plan \\
\hline Environmental Permit & $\square$ & Inventory Adjustment Request \\
\hline
\end{tabular}

$\begin{array}{lll}\square & \text { Tank Calibration Manual } & \square \\ \square & \text { Health Physics Procedure } & \square \\ \square & \text { Spares Multiple Unit Listing } & \square \\ \square & \text { Test Procedures/Specification } & \square \\ \square & \text { Component Index } & \square \\ \square & \text { Hume Coded Item } & \square \\ \square & \text { Computer Software } & \square \\ \square & \text { Electric Circuit Schedule } & \square \\ \square & \text { ICRS Procedure } & \square \\ \square & \text { Process Control Manual/Plan } & \square \\ \square & \text { Purchase Requisition } & \square \\ \square & \text { Tickler File } & \square\end{array}$

20. Other Affected Documents: (NOTE: Documents listed below will not be revised by this ECN.) Signatures below indicate that the signing organization has been notified of other affected documents listed below.

None

Design Authority

Cog. Eng. CE Wills

Cog. Mgr. JR Weidert

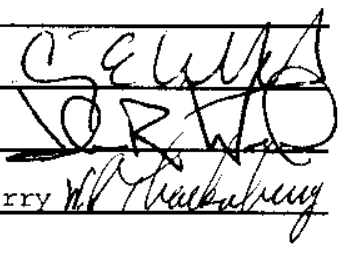

Safety

Environ.

Other

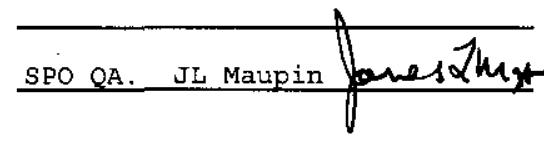

Design Agent

PE

QA

Safety

Design

Environ.

Other
$3 / 10 / 00$
DEPARTMENT OF ENERGY

Signature or a Control Number that tracks the Approval Signature

ADDITIONAL 


\section{DISTRIBUTION SHEET}

To

DISTRIBUTION

Project Title/Work Order

HNF-5148, Rev. 2, Calibration Report for the WRAP Facility GEA System

\section{Name}

\section{MG Cantaloub}

AI Davis

WG Jasen

JL Maupin

MA Purcell

WR Thackaberry

CE Taylor

JR Weidert

CE Wills

DOE/RL Reading ROOm

Engineering Files
From

WRAP ENGINEERING

Page 1 of 1

Date $03 / 07 / 00$

EDT No. N/A

ECN No. ECN-657508

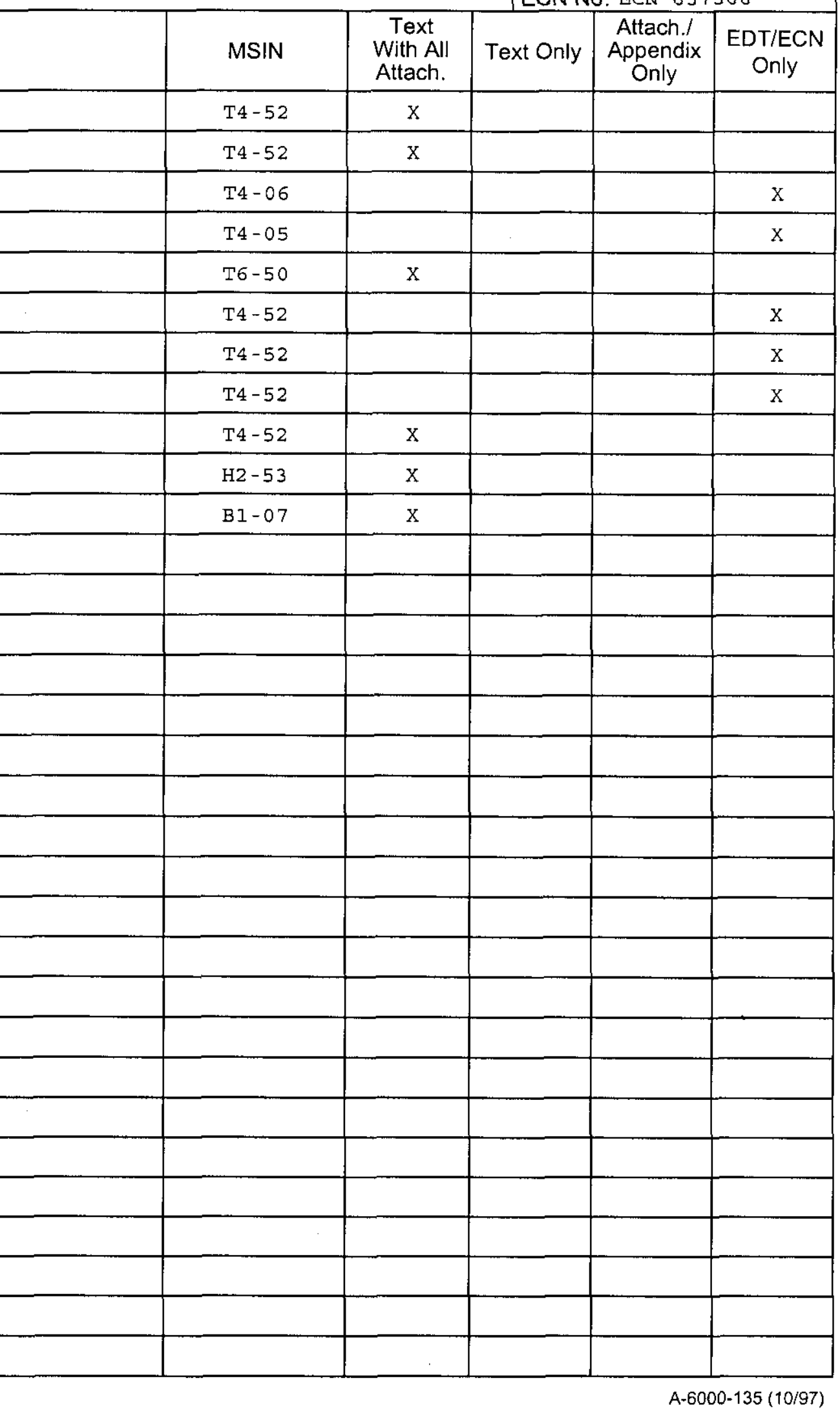

\begin{tabular}{|l|c|c|c|c|c|} 
Name & MSIN & $\begin{array}{c}\text { Text } \\
\text { With All } \\
\text { Attach. }\end{array}$ & Text Only & $\begin{array}{c}\text { Attach./ } \\
\text { Appendix } \\
\text { Only }\end{array}$ & $\begin{array}{c}\text { EDT/ECN } \\
\text { Only }\end{array}$ \\
\hline & $T 4-52$ & $\mathrm{X}$ & & & \\
\hline & $\mathrm{T} 4-52$ & $\mathrm{X}$ & & & \\
\hline & $\mathrm{T} 4-06$ & & & & $\mathrm{X}$ \\
\hline & $\mathrm{T} 4-05$ & & & & $\mathrm{X}$ \\
\hline & $\mathrm{T} 4-50$ & $\mathrm{X}$ & & & $\mathrm{X}$ \\
\hline & $\mathrm{T} 4-52$ & & & & $\mathrm{X}$ \\
\hline & $\mathrm{T} 4-52$ & & & & $\mathrm{X}$ \\
\hline & $\mathrm{T} 4-52$ & $\mathrm{X}$ & & & \\
\hline & $\mathrm{H} 2-53$ & $\mathrm{X}$ & & & \\
\hline
\end{tabular}


HNF-5148

Revision 2

es

\section{Calibration Report For The WRAP Facility Gamma Energy Assay System}

Prepared for the U.S. Department of Energy

Assistant Secretary for Environmental Management

Project Hanford Management Contractor for the

U.S. Department of Energy under Contract DE-AC06-96RL13200

Fluor Hanford

P.O. Box 1000

Richland, Washington

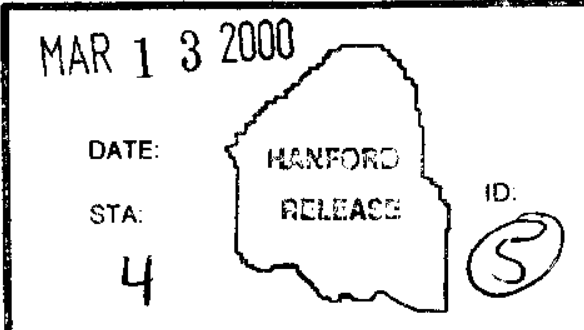


HNF-5148

Revision 2

\section{Calibration Report For The WRAP Facility Gamma Energy Assay SystemCalibration Report For The WRAP Facility}

CE Wills

Flour Hanford

EDT/ECN: ECN-657508

Total Pages: $\begin{aligned} & \lg 3 / 3 / 300 \\ & 132\end{aligned}$

Registered Trademarks:

- Genie-PC is a registered trademark of Digital Equipment Corporation, Huston, TX.

" MGA Software is a registered trademark of Mitchell \& Gauthier Associates, Inc. Concord, MA.

Date Published

March 2000

Prepared for the U.S. Department of Energy

Assistant Secretary for Environmental Management

\section{Fluor Hanford}

P.O. Box 1000

Richland, Washington 


\section{INFORMATION CLEARANCE FORM}

\begin{tabular}{ll|l}
\hline \multicolumn{2}{|c|}{ A. Information Category } & B. Document Number HNF-5148, Rev. 2 . \\
\cline { 2 - 2 } & $\square$ Journal Article & C. Title \\
$\square$ Abstract & $\square$ Internet & Calibration Report for the WRAP Facility Gamma energy Analysis \\
$\square$ Summary & $\square$ Software & System. \\
$\square$ Visual Aid & $\square$ Report & \\
$\square$ Full Paper & & D. Internet Address N/A \\
$\square$ Other & &
\end{tabular}

E. Required Information

1. Is document potentially Classified? O No OYes (MANDATORY)

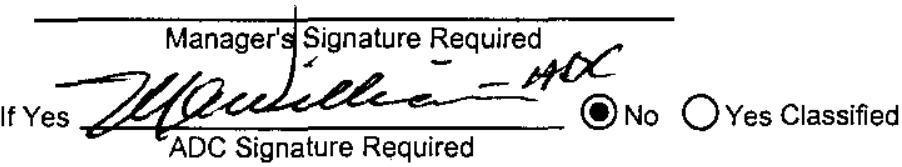

2. Internal Review Required? ONo OYes

If Yes, Document Signatures Below

Counsel

Program

3. References in the Information are Applied Technology ONo OYes Export Controlled Information

Ono Ores
4. Does Information Contain the Following: (MANDATORY)

a. New or Novel (Patentable) Subject Matter? ONo OYes If "Yes", Disclosure No:

b. Information Received in Confidence, Such as Proprietary and/or Inventions?

No OYes If "Yes", Affix Appropriate Legends/Notices.
c. copyrights? ONo OYes
If "Yes", Attach Permission.
d. Trademarks? $\mathrm{No}$
YYes
If "Yes", Identify in Document.

5. Is Information requiring submission to OSTI? $O$ No $\bigcirc$ Yes

If Yes UCand $B \& R-$

6. Release Level? $O$ Public $\bigcirc$ Limited

7. Charge Code_AJ60

F. Complete for a Journal Article

1. Title of Journal

G. Complete for a Presentation

1. Titte for Conference or Meeting

2. Group Sponsoring

3. Date of Conference

4. City/State

5. Will Information be Published in Proceedings? $\bigcirc$ No $\bigcirc$ Yes

H. Author/Requestor

CE Wills

(Print and Sign)

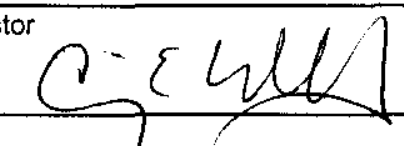

1. Reviewers

Yes Print

6. Will Material be Handed Out?

Responsible Manage

JR Weidert (Print and Sign)

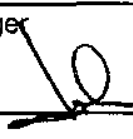

Signature

Public Y/N (If N, complete J)

General Counsel

$\square$

.

$\mathrm{Y} / \mathrm{N}$

Office of External Affairs

DOE-RL

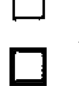

Other

$\square$

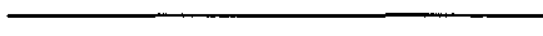

$\mathrm{Y} / \mathrm{N}$

$\mathrm{Y} / \mathrm{N}$

$\mathrm{Y} / \mathrm{N}$

Other

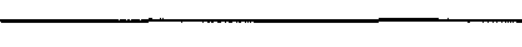

$\mathrm{Y} / \mathrm{N}$

J. If Information Includes Sensitive Information and is not to be released to the Public indicate category below.
$\square$ Applied Technology
$\square$ Protected CRADA
$\square$ Personal/Private
$\square$ Export Controlled
$\square$ Proprietary
$\square$ Business-Sensitive
$\square$ Procurement-Sensitive
$\square$ Predecisional
$\square$ Patentable
$\square$ UCNI
$\square$ Other (Specify)

K. If Additional Comments, Please Attach Separate Sheet 


\section{RELEASE AUTHORIZATION}

\begin{tabular}{|ll|}
\hline Document Number: & HNF-5148, REV 2 \\
\hline Document Title: & $\begin{array}{l}\text { Calibration Report for the WRAP Facility Gamma } \\
\text { Energy Assay System }\end{array}$ \\
\hline
\end{tabular}

This document, reviewed in accordance with DOE Order 241.1, "Scientific and Technical Information Management," and 241.1-1, "Guide to the Management of Scientific and Technical Information," does not contain classified or sensitive unclassified information and is:

\section{APPROVED FOR PUBLIC RELEASE}

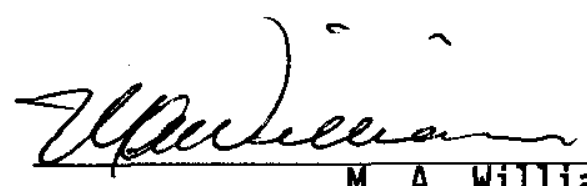

M. A. Williams

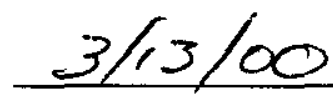

Lockheed Martin Services, Inc. Document Control/Information Clearance

Reviewed for Applied Technology, Business Sonsitivo, Claseified, Copyrighted, Export Controllod, Patent, Porsonal/Private, Proprietary, Protected CRADA, Trademark, Unclassified Controlled Nuclear Information.

LEGAL DISCLAIMER. This report was prepared as an account of work eponsored by an agency of the United States Government. Neither the United States Government nor any agency thereof, not any of their employees, nor any of their contractors, subcontractors or their employess, makes any warranty, express or implied, or assumes any legat liability or responsibility for the accuracy.

completeness, or any third party's use or the results of such use of any information, apparatus, product, or process disclosed, or represents that its use would not infringe privately owned rights. Reference herein to any opecific commercial product, process, or service by trade name, trademerk, manufacturer, or otherwise, does not necessarily constitute or imply its ondorsement, recommendation, or favoring by the United States Government or any agency thereof or its contractors or subcontractors. The views and opinione of authors expressed herein do not necessarily state or refloct those of the United States Government or any agency thereof. This report has been reproduced from the best available copy. Printed in the United States of America. 
TRADEMARK DISCLAIMER

Reference herein to any specific commercial product, process, or service by trade name, trademark, manufacturer, or otherwise, does not necessarily constitute or imply its

endorsement, recommendation, or favoring by the United

States Government or any agency thereof or its contractors or subcontractors.

This report has been reproduced from the best available copy.

Printed in the United States of Americe 


\section{RECORD OF REVISION}

(2) Title

Calibration Report for the WRAP Facility Gamma Energy Assay (GEA) System

Change Control Record

(3) Revision

0

$0-A$

Rer

Replace pages 8 through 11 ,

Replace pages $\mathrm{B}-1$ and $\mathrm{B}-2$

Per ECN 655133

1

Complete revision per ECN 655138

RS 2

Complete revision per ECN-657508

Authorized for Release

\begin{tabular}{l|ll} 
(5) Cog. Engr. & (6) Cog. Mgr. Date
\end{tabular}

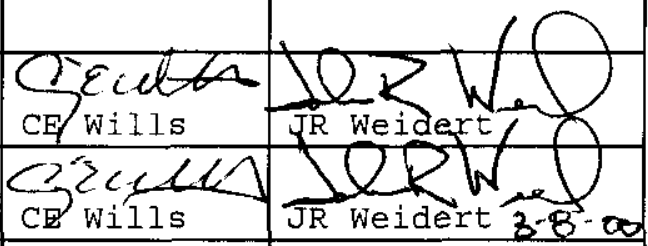


HNF-5148, Rev. 2

\section{CALIBRATION REPORT}

FOR

GAMMA ENERGY ANALYSIS SYSTEM

104-ND-06-102 A

REVISION 1

Prepared for

Waste Receiving and Processing Facility Engineering

Prepared by

Albert I. Davis

Waste Management Technical Services

March, 2000 
HNF-5148, Rev. 2

\section{Certificate of Calibration}

This calibration report outlines the specific items included in the TRU Control of Measuring, Testing and Data Collection Equipment ${ }^{(1)}$.

Equipment Identifier:

Calibration Interval:

Date of Calibration:

Calibration Verification

Due date:

Limitations:

Calibration applies to

Listed equipment:

Calibration Method

Calibration range and Tolerance:

Calibration Acceptability:

Standards

Performers of Calibration:

Reference to Out-of-Cal., or non-conformance issues:
104-ND-06-102 A, GEA-A

Calibration upon installation, then calibration verification annually thereafter.

20 January, 2000 and $6 \mathrm{March}, 2000$

20 January, 2001

55 gallon drums.

104-ND-06-102 A

WMH 350 Section 2.5.

Gamma energy range from $35 \mathrm{keV}$ to $2.0 \mathrm{MeV}$. Tolerance error is developed within the proprietary Canberra ${ }^{(2)}$ calibration software. Analytical span, 0 to 160 grams ${ }^{239} \mathrm{Pu}$ defined in $\mathrm{HNF}-4051^{(3)}$.

Calibration has been deemed acceptable with no non-conformance items.

Standards are listed in Appendix B of this document.

The system Cognizant Engineer: Graig Wills.

Signature:
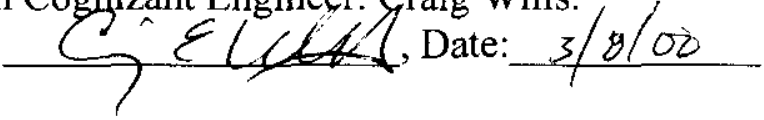
HNF-5148, Rev. 2

Table of Contents

Certificate of Calibration

Page

1.0 Introduction

5

2.0 Calibration Configuration 5

3.0 GWAS Detectors 5

$\begin{array}{ll}4.0 \text { GWAS Configuration } & 6\end{array}$

5.0 Vertical Activity Response $\quad 7$

6.0 Comparative Analysis 8

$7.0 \quad$ SEGe Detectors 9

$\begin{array}{lll}\text { 8.0 Low Energy Detectors } & 12\end{array}$

$\begin{array}{lll}9.0 & \text { SEGe Efficiency } & 12\end{array}$

10.0 Transmission Calibration 16

$\begin{array}{ll}11.0 \text { References } & 21\end{array}$

Appendix A, Calibration Configuration A1-A4

$\begin{array}{ll}\text { Appendix B, Source Certificates } & \text { B1-B15 }\end{array}$

$\begin{array}{ll}\text { Appendix C, Detector Specifications } & \mathrm{C} 1-\mathrm{C} 12\end{array}$

Appendix D, Energy \& FWHM Data and Curves D1-D8

Appendix E, SEGe Efficiency Data and Curves E1-E51

$\begin{array}{ll}\text { Appendix F, Worksheet Data } & \text { F-1-F-9 }\end{array}$ 
HNF-5148, Rev. 2

Intentionally Blank 


\subsection{Introduction}

The Waste Receiving And Processing facility (WRAP) adheres to providing gamma-ray spectroscopy instrument calibrations traceable to the National Institute for Standards and Technology (NIST) standards ${ }^{(4)}$. The detectors are used to produce quantitative results for the Waste Isolation Pilot Plant (WIPP) and must meet calibration programmatic calibration goals. Instruments must meet portions of ANSI N42.14, 1978 guide for Germanium detectors. The Non-Destructive Assay (NDA) Gamma Energy Analysis (GEA) utilizes NIST traceable line source standards for the detector system calibrations. The counting configuration is a series of drums containing the line sources and different density filler matrices. The drums are used to develop system efficiencies with respect to density. The efficiency and density correction factors are required for the processing of drummed waste materials of similar densities. The calibration verification is carried out after the calibration is deemed final, by counting a second drum of NIST traceable sources. Three in-depth calibrations have been completed on one of the two systems to date, the first being the system acceptance plan.

This report has a secondary function; that being the development of the instrument calibration errors which are to be folded into the Total Instrument Uncertainty document, HNF-4050.

\subsection{Calibration Configuration}

The two gamma systems, GEA-A and GEA-B, are calibrated utilizing a vendor supplied drum with six full length line sources distributed in a radial related pattern and differing density fillers. A study by the vendor was cited to develop the source placement. The recommended source placement pattern is considered the best representation of a homogeneous distribution of activity in the drum; see Appendix A. This drum source is the sole calibration source geometry for the Gamma Waste Analysis System, GWAS, for the development of efficiency curves, The source certifications, D846-D851, are in Appendix B, The uncertainties listed on the certificates are at 3 $\sigma(2.576)$, per telecom from the supplier.

\subsection{GWAS detectors}

The Gamma Energy Analysis (GEA) system utilizes six detectors; four are the Segmented Energy Germanium gamma detectors (SEGe-\#) used for quantitative analysis, and two Low Energy Germanium detectors (LEGe-\#) which are used for peak ratios analysis of low energy gamma-rays from the 45 to $300 \mathrm{keV}$ region. The segmented detectors are $22 \%$ to $25 \%$ efficient HPGe detectors (High Purity Germanium) relative to a $3 \times 3 \mathrm{NaI}(\mathrm{Tl})$ detector. The detector specifications are in Appendix $\mathrm{C}$; they are not identified with a particular system, but, are the system detectors. The SEGe detectors have gamma attenuators that can be activated to reduce the drum gamma-ray activity to levels that the detector and their electronics can handle without signal distortion. The system drawings state the attenuators are 0.5 inch $(1.125 \mathrm{~cm})$ thick, and are machined Iron plate. 
HNF-5148, Rev. 2

\subsection{GWAS Configuration}

The GWAS counting system ${ }^{(5)}$, detectors, shield and the drum elevation platform will adequately analyze 55 and 85 gallon drums (208 and 321.5 liters), see Figure 1 bottom. The drum platform elevates in two steps, $8.9 \mathrm{~cm}$ each, and the platform continually rotates at $10 \mathrm{rpm}$ during analysis and calibrations, The middle diagram shows the SEGe gamma detector's angle of coverage for the drums. These zones of sensitivity overlap and ensure the entire drum is scanned. The lowest segment in the analysis group views only the rotational portion of the platform and is not

included in the calibration. The highest segment in the group views the drum lid and "air" space, it also is not included in the calibration for 55 gallon drums.
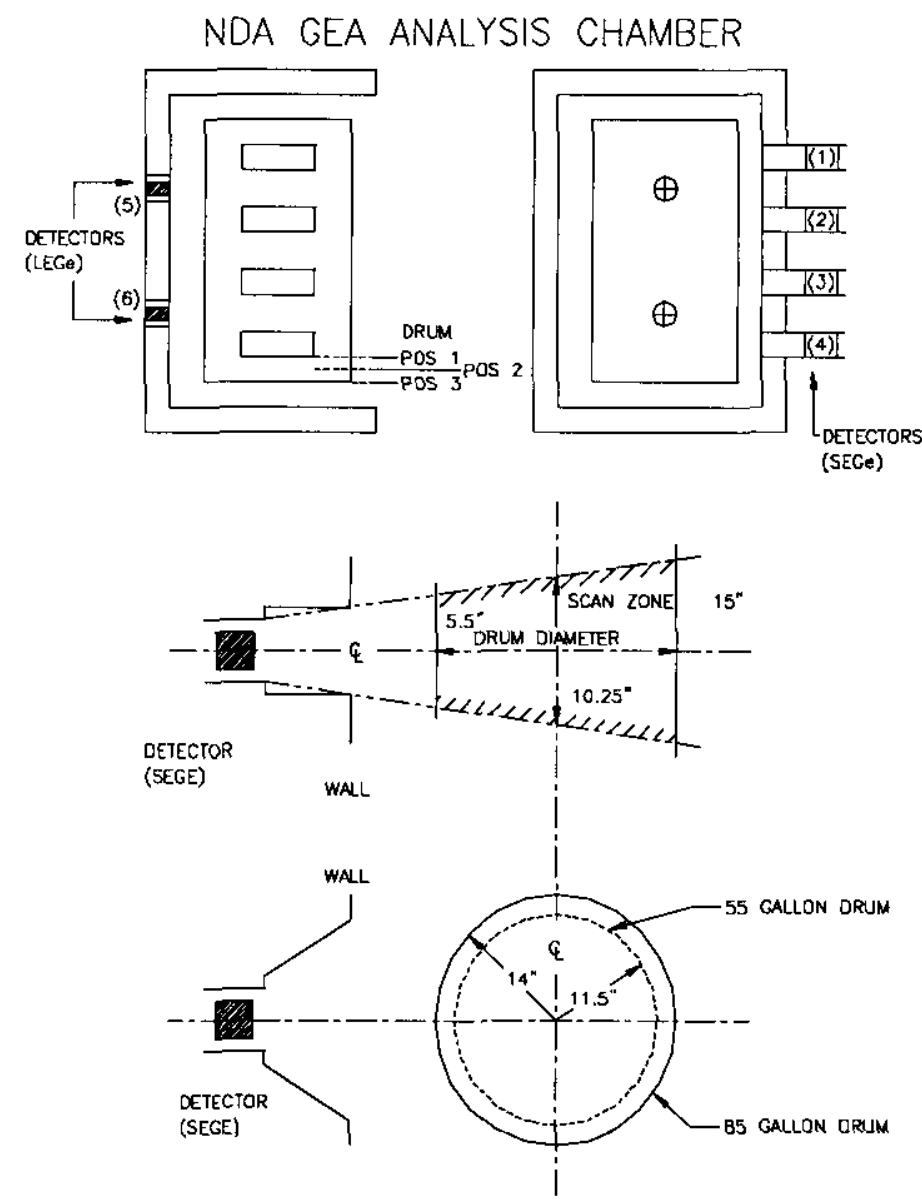

Figure 1. NDA detector layout and zone of sensitivities. 
HNF-5148, Rev. 2

\subsection{Vertical Activity Response}

A series of counts were made with the daily source check drum, following calibration, to evaluate system parameters. The system's response to the standards is shown in the next two figures. Figure 2 is a plot of the counts for selected calibration peaks versus SEGe and position. Note that analytical segment 11 is the top of the drum. The segment's count along the vertical axis is reduced for the drum extremities; the bottom two analysis groups are lower as well as the upper two analysis groups. This count distribution will reflect the efficiency curve's as well.

\section{Isotopic Count Response}

Jan, 2000

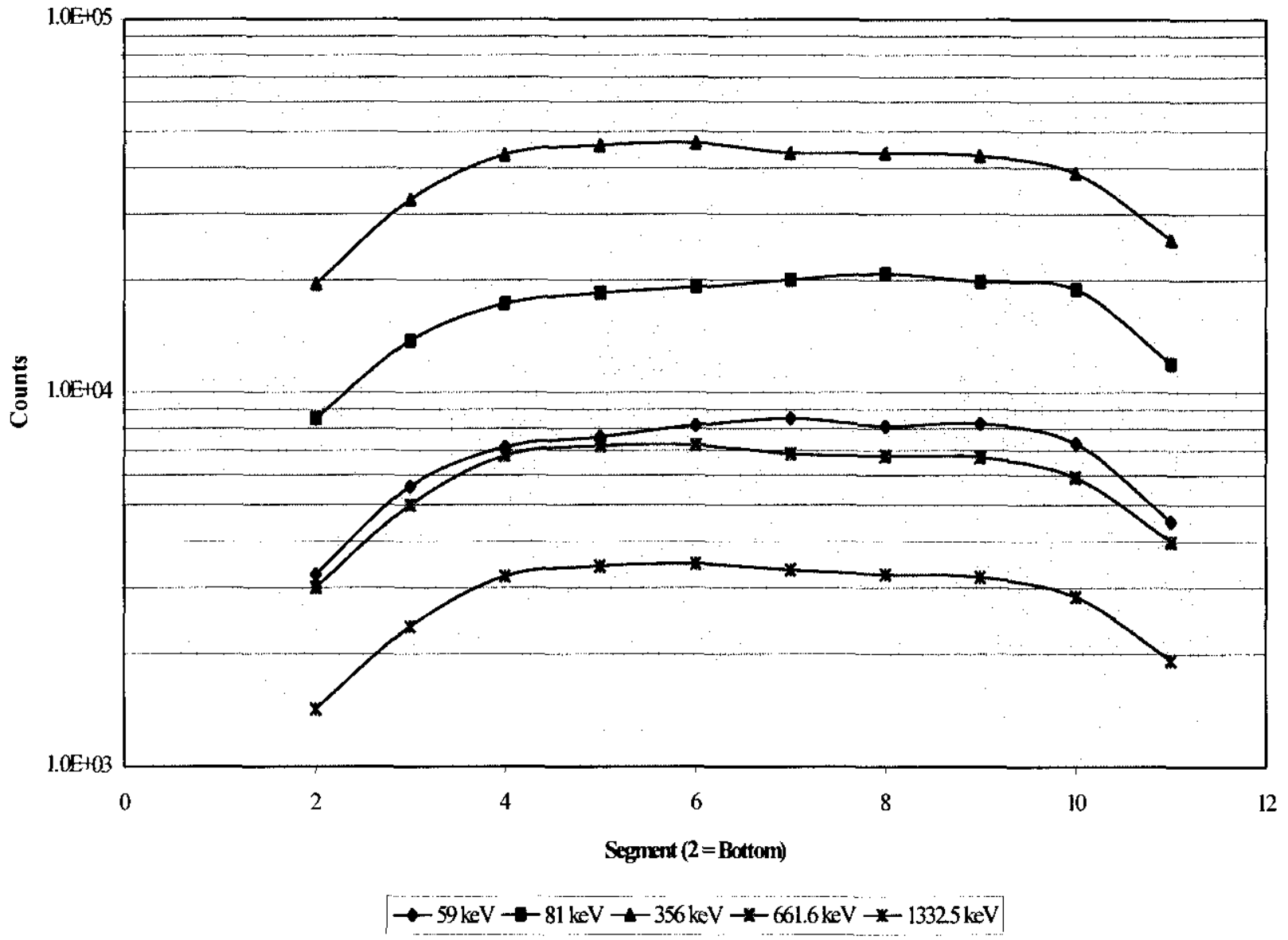

Figure 2. 


\subsection{Comparative Analysis}

The daily control drum, using a separate set of six NIST traceable line sources, E838-E843, was analyzed a multiple of times to evaluate the response to the calibration. One feature was to view the activity per segment; Figure 3 portrays a plot of that activity versus segment. This plot demonstrates the system's ability to reproduce the drum's vertical isotopic activity. The plot does not indicate losses at the drum extremes. The spreadsheet for Figures 2 and 3 are in Appendix F.

Isotopic Activity Response

Jan 2000

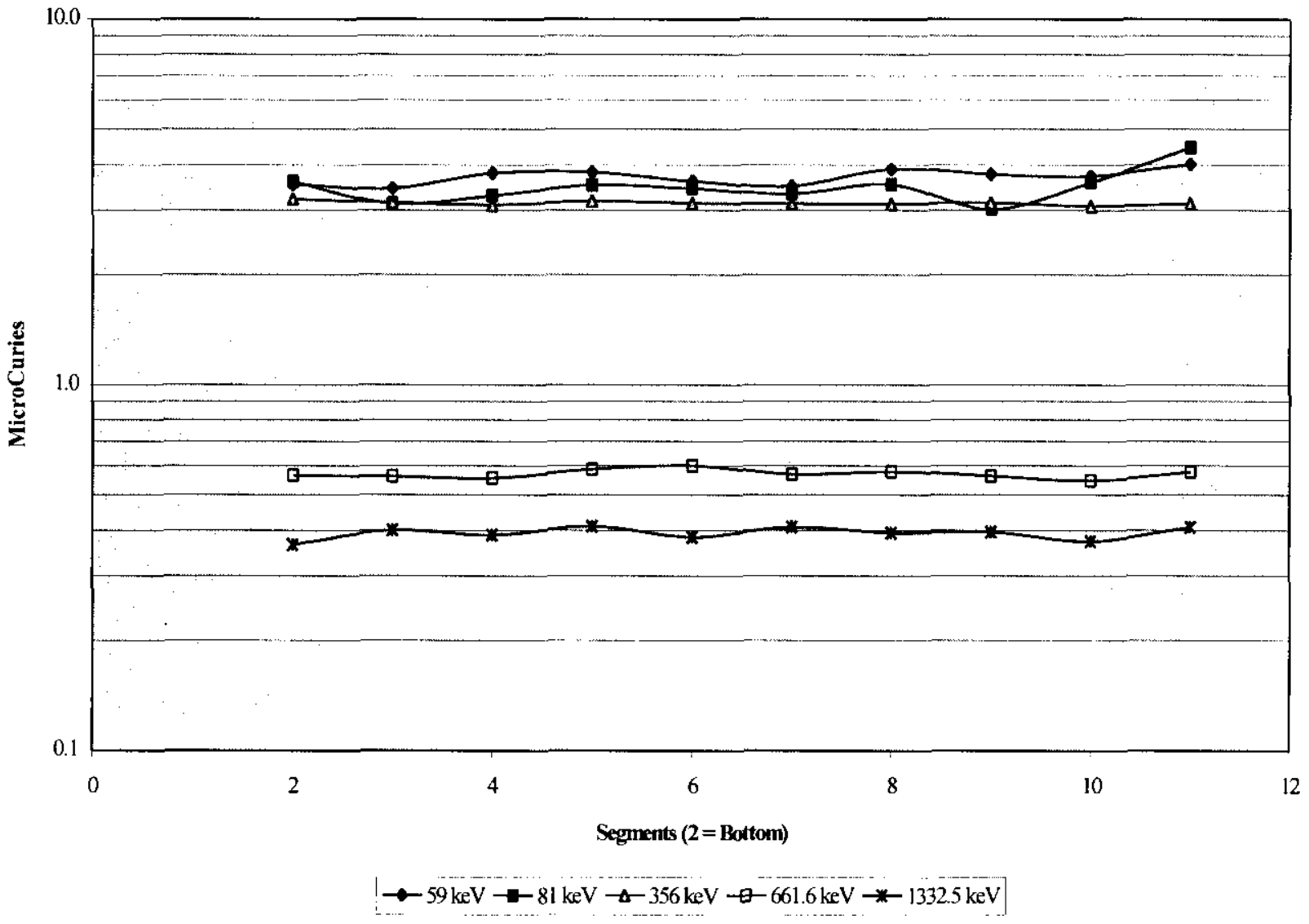

Figure 3.

The following table, Table 1, displays the calibration on a second separate NIST traceable source drum. This drum is configured in the exact same geometry, but, with another second set of rod (line) sources; certificates are shown in Appendix B, E838 to E843. This particular evaluation could be considered the calibration verification. 
HNF-5148, Rev. 2

\begin{tabular}{|c|c|c|c|c|c|c|c|c|c|c|c|}
\hline \multirow[b]{2}{*}{ Seg \# } & \multicolumn{3}{|c|}{$59 \mathrm{k} \mathrm{eV}$} & \multicolumn{2}{|l|}{$81 \mathrm{keV}$} & \multicolumn{2}{|l|}{$356 \mathrm{keV}$} & \multicolumn{2}{|c|}{$661 \mathrm{keV}$} & \multicolumn{2}{|c|}{$1332.5 \mathrm{keV}$} \\
\hline & Seg & $A \vee G$ & $\% \mathrm{err}$ & AVG & $\%$ err & $A V G$ & $\% \mathrm{crr}$ & $A V G$ & $\%$ err & $\mathrm{AVG}$ & $\%$ err \\
\hline 11 & $\mathrm{~S} 12$ & 4.02 & 2.46 & 4.46 & 3.90 & 3.13 & 1.61 & 0.577 & 1.89 & 0.408 & 1.61 \\
\hline 10 & $\mathrm{~S} 13$ & 3.73 & 1.44 & 3.58 & 1.04 & 3.08 & 1.61 & 0.547 & 2.08 & 0.373 & 1.61 \\
\hline 9 & $\mathrm{~S} 21$ & 3.77 & 2.49 & 3.02 & 7.61 & 3.15 & 1.37 & 0.563 & 1.20 & 0.395 & 1.37 \\
\hline 8 & $\mathrm{~S} 22$ & 3.90 & 1.82 & 3.54 & 6.28 & 3.12 & 1.93 & 0.579 & 1.81 & 0.394 & 1.93 \\
\hline 7 & S23 & 3.50 & 1.58 & 3.33 & 3.68 & 3.13 & 0.580 & 0.569 & 1.06 & 0.408 & 0.580 \\
\hline 6 & $\mathrm{~S} 31$ & 3.61 & 1.67 & 3.45 & 1.43 & 3.14 & 1.39 & 0.601 & 0.688 & 0.384 & 1.39 \\
\hline 5 & $\mathrm{~S} 32$ & 3.82 & 2.10 & 3.52 & 1.55 & 3.18 & 1.49 & 0.588 & 1.28 & 0.411 & 1.49 \\
\hline 4 & S33 & 3.80 & 2.95 & 3.30 & 1.95 & 3.11 & 1.79 & 0.557 & 1.57 & 0.388 & 1.79 \\
\hline 3 & S41 & 3.45 & 3.00 & 3.13 & 16.06 & 3.16 & 1.66 & 0.562 & 0.701 & 0.400 & 1.66 \\
\hline 2 & $\$ 42$ & 3.54 & 2.70 & 3.59 & 10.82 & 3.22 & 2.64 & 0.566 & 1.56 & 0.366 & 2.64 \\
\hline $\mathrm{A} 04$ & & 37.27 & 1.05 & 34.28 & 0.496 & 32.11 & 0.455 & 5.93 & 0.186 & 4.04 & 0.455 \\
\hline Sum & $\%$ Diff & 37.14 & 0.35 & 34.91 & -1.85 & 31.44 & 2.10 & 5.71 & 3.79 & 3.93 & 2.76 \\
\hline Src Act & & 35.97 & 2.77 & 31.62 & 2.91 & 31.62 & 2.91 & 5.57 & 3.42 & 3.94 & 3.05 \\
\hline Ratio & $\mathrm{A} 04 / \mathrm{Std}$ & 1.036 & & 1.08 & & 1.02 & & 1.07 & & 1.03 & \\
\hline & Sunv/Std & 1.032 & & 1.10 & & 0.994 & & 1.03 & & 0.997 & \\
\hline
\end{tabular}

Table 1. Daily QC-57 drum response.

The total activity is calculated in Table 1, note specifically the rows for the activity ratios to the standard, per isotope. The summed spectrum analysis is contained in the A04 module and its ratio to the actual standard is A04/Std. The summation of each of the segment's activity into a summed activity is ratioed to the standard; Sum/Std. The agreement in both cases is quite good, better than $4 \%$. The $81 \mathrm{keV}$ peak of ${ }^{133} \mathrm{Ba}$ has less agreement due to the interference produced by lead X-rays from unshielded lead next to the detectors.

\subsection{SEGe Detectors}

The Segmented detectors are set to view energy from $35 \mathrm{keV}$ to $2.0 \mathrm{MeV}$ within a 4096 channel memory block. The gain and zero are carefully adjusted to ensure the resolution is not lost during the summation of the spectra of the individual segmented counts. The Canberra program also contains a built in function to aid in the zero and gain normalization for this summation. The effectiveness of this summation is demonstrated in Table 2 and its associated graph, Figure 4. 
HNF-5148, Rev. 2

The energy equations are of the form:

\begin{tabular}{lccc}
\multicolumn{4}{c}{ Energy $(\mathrm{keV})=\mathrm{a}+\mathrm{b}^{*} \mathrm{chn}+\mathrm{c}^{*} \mathrm{chn}^{2}$} \\
Detector & $\begin{array}{c}\text { Intercept } \\
\text { Multiplier } \\
\text { (a) }\end{array}$ & $\begin{array}{c}\text { Linear } \\
\text { Multiplier } \\
\text { (b) }\end{array}$ & $\begin{array}{c}\text { Quadratic } \\
\text { Multiplier }\end{array}$ \\
SEGe-1 & -0.983 & 0.500 & $-1.68 \mathrm{E}-07$ \\
SEGe-2 & -0.757 & 0.500 & $-1.72 \mathrm{E}-07$ \\
SEGe-3 & -0.693 & 0.500 & $-1.64 \mathrm{E}-07$ \\
SEGe-4 & -1.687 & 0.501 & $-1.51 \mathrm{E}-07$ \\
Summed & -1.691 & 0.501 & $1.54 \mathrm{E}-07$
\end{tabular}

Table 2.

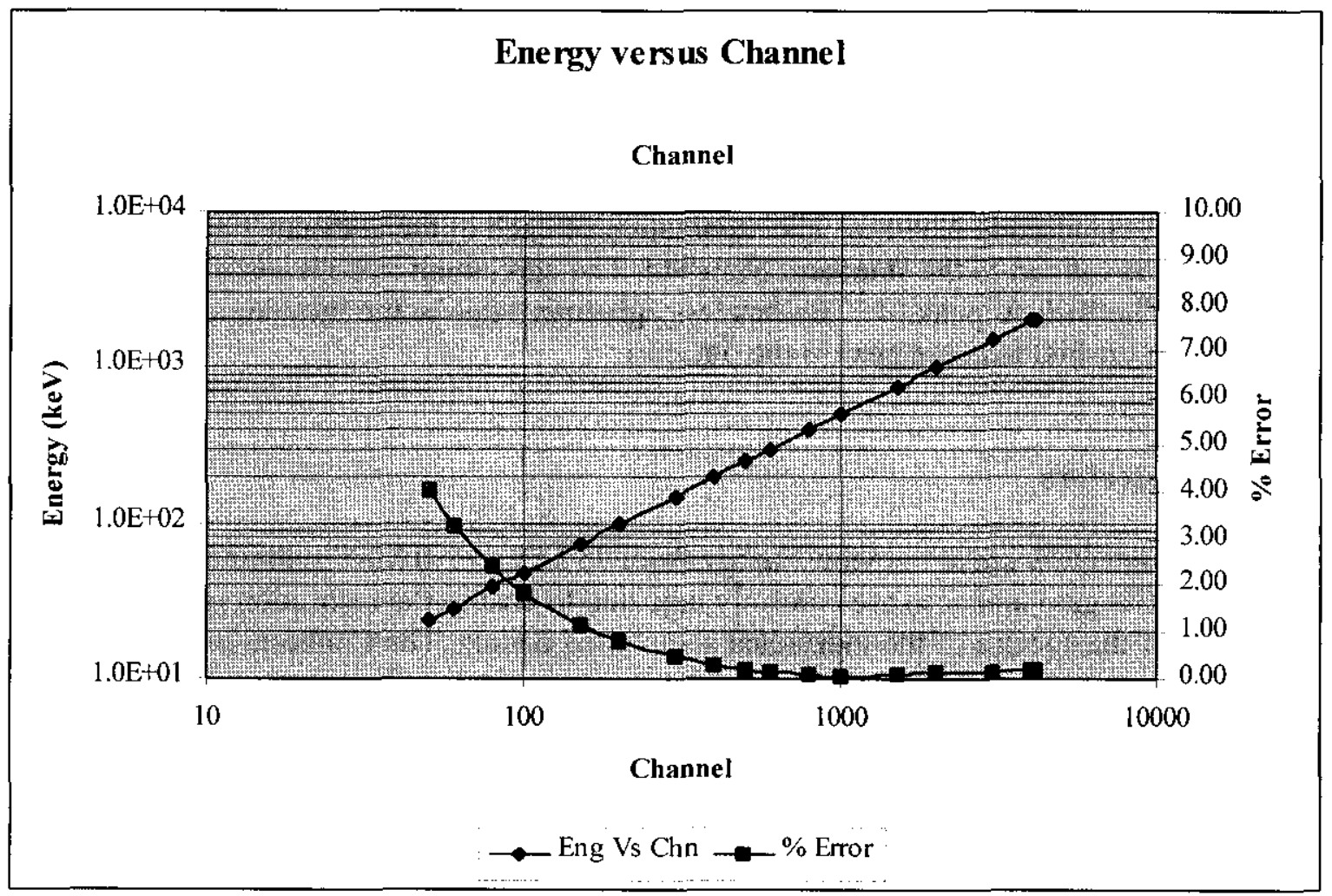

Figure 4

The Energy versus Channel plot demonstrated the good fit of the equations to the summed spectrum plot. The individual SEGe detectors are adjusted to as close as practical to the ideal setting, thus the low error values. 
The equations for energy and FWHM also demonstrate this normalization effect in the consistency of the equation's coefficients as follows:

\section{FWHM vs Energy}

\begin{tabular}{lrr} 
& FWHM $(\mathrm{keV})=\mathrm{a}+\mathrm{b}^{*} E^{0.5}$ \\
& $\mathbf{a}$ & \multicolumn{1}{c}{ b } \\
SEGe-1 & 0.543 & 0.030 \\
SEGe-2 & 0.378 & 0.039 \\
SEGe-3 & 0.543 & 0.032 \\
SEGe-4 & 0.529 & 0.029 \\
Summed & 0.605 & 0.033
\end{tabular}

Table 3.

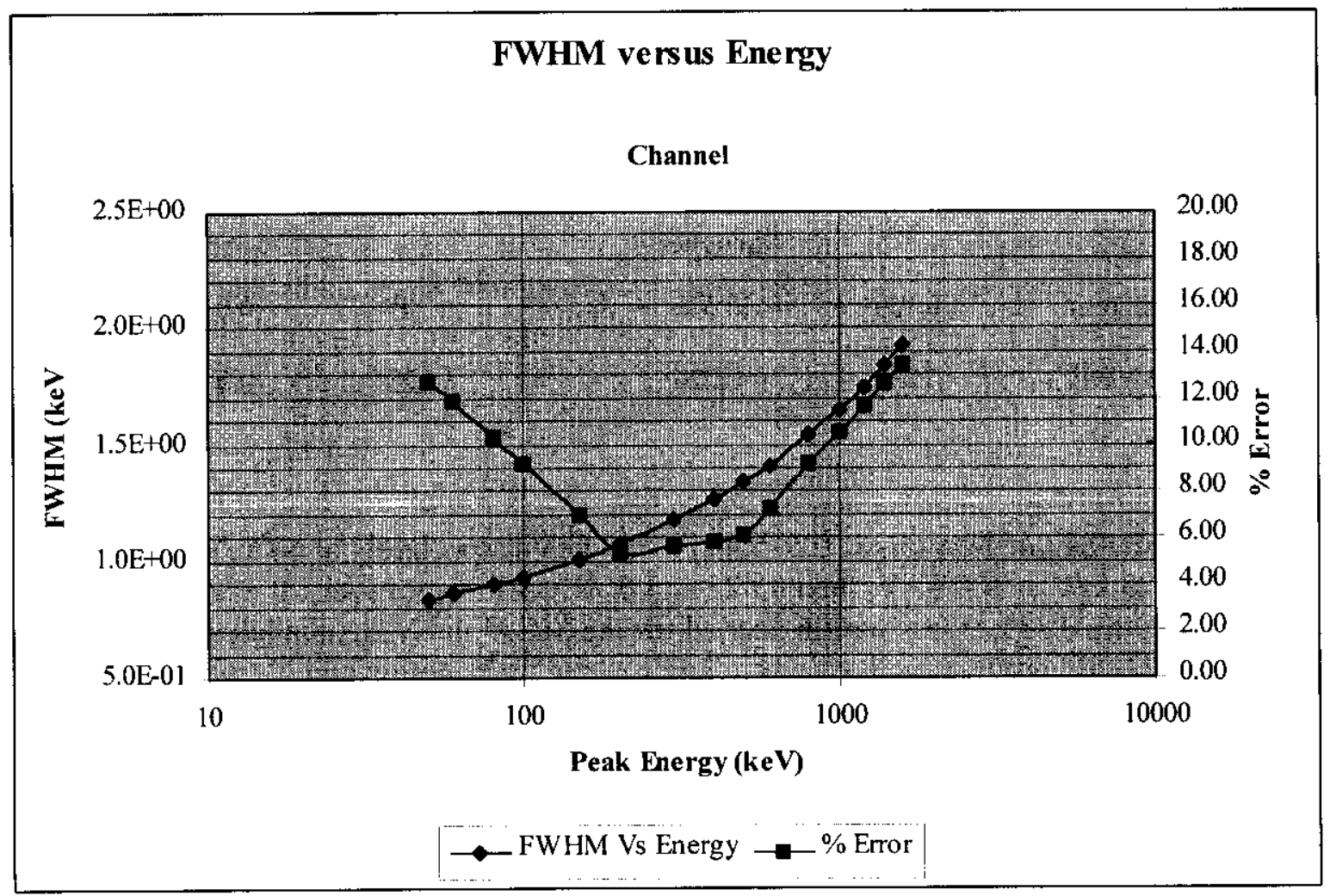

Figure 5.

The FWHM plot does demonstrate that broadening occurs in the spectrum summation; one of the SEGe detectors (2), is wider than the others and causes the error to increase at the higher energies. The combination of these two plots suggest peak identification should be within the 
acceptable parameters for the gamma analysis program. The individual curves for the detectors are with the parameter printouts in Appendix D.

\subsection{Low Energy Detectors}

The two LEGe HPGe detectors are $10 \%$ efficient relative to a $3 \times 3 \mathrm{NaI}(\mathrm{Tl})$ detector. The detector crystal has less depth to enhance the efficiency of the lower energy gamma-rays. These detectors are shielded with $31 \mathrm{mil} \mathrm{Sn}$. These detectors are calibrated only for energy and FWHM (Full Width at Half Maximum) parameters. The detectors need to have good resolution and have little degradation with respect to high gamma-ray throughput rates. Figure 1 shows the placement of these detectors.

The LEGe detectors, used for the MGA ${ }^{(6)}$ and MGAU analysis are looked upon as separate entities, that is no spectrum summing is done. The energy range for these detectors is from 35 to $300 \mathrm{keV}$ stored into a 4096 channel buffer. Calibration for energy is linear and has only two terms, a requirement of the $\mathrm{MGA} / \mathrm{MGAU}$ software. The equations are as follows:

$$
\text { Energy }(\mathrm{keV})=\mathrm{a}+\mathrm{b}^{*} \text { Chn } \quad \text { FWHM }(\mathrm{keV})=\mathrm{a}+\mathrm{b}^{*} \operatorname{Eng}^{0.5}
$$

\begin{tabular}{lcccc} 
& \multicolumn{2}{c}{ Energy equation } & \multicolumn{2}{c}{ FWHM Equation } \\
& Intercept & $\begin{array}{l}\text { Linear } \\
\text { Multiplier }\end{array}$ & Intercept & \multicolumn{1}{l}{ Linear } \\
Detector & 0.159 & 0.076 & 0.273 & Multiplier \\
LEGe-5 (Upper) & 0.150 & 0.076 & 0.039 \\
LEGe-6 (Lower) & 0.223 & 0.040
\end{tabular}

Table 4.

The FWHM for the LEGe detectors is 0.575 and $0.533 \mathrm{keV}$ respectively at $60 \mathrm{keV}$ and increases to 0.663 and $0.623 \mathrm{keV}$ at $100 \mathrm{KeV}$, then 0.825 and $0.789 \mathrm{keV}$ respectively at $200 \mathrm{keV}$. The FWHM is within the $0.85 \mathrm{keV}$ resolution needed for the MGA and MGAU analysis software. The MGA and MGAU program is designed to analyze for both gamma and X-ray peak areas below $300 \mathrm{keV}$. The LEGe detectors are not calibrated for efficiency, as the Canberra program doesn't calculate activities from these spectra, only compares relative peak areas. The energy and FWHM data is included in Appendix D for the LEGe detectors.

\subsection{SEGe Efficiency}

The efficiency calibration output for the segmented detectors is contained in Appendix E. The efficiency curve formulas are the "best fit" selected from the regression analysis contained in the Canberra ${ }^{(7)}$ software. The equation's coefficients listed below are in two groups; one without the collimators (shields) activated, and the second with the collimators activated. Each equation takes the basic form: 


$$
\operatorname{Ln}(E f f)=a+b^{*} \operatorname{Ln}(E)+c^{*} \operatorname{Ln}(E)^{2}+d^{*} \operatorname{Ln}(E)^{3}+\ldots
$$

The spreadsheet containing the equation's coefficients are in Appendix F, F8 and F9. The efficiency parameters can regenerate portions of the Canberra's software curve, but lack the inflection point input to completely draw the efficiency curve. The error associated with each efficiency point also includes the error developed in the regression analysis matrix. The error listing or report is not readily available for printout as an equation or plot. Uncertainty for selected efficiencies is discussed below.

Figures 5 and 6 displays the efficiency curve variations with respect to density, Figure 5 has the curves for a non-shielded count, No Collimator, while Figure 6 is the efficiency curves with the shield (Collimator).

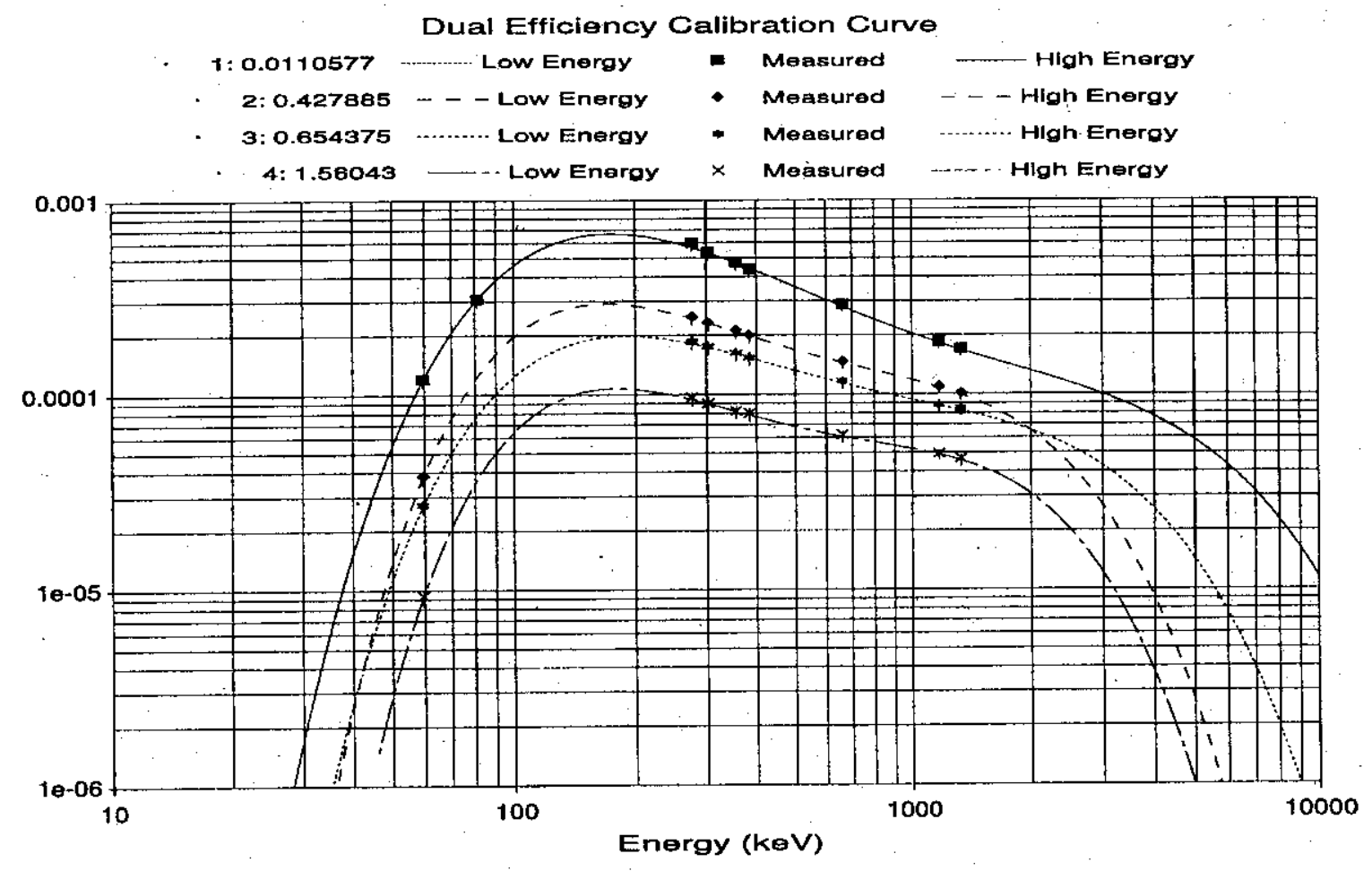

Figure 5: No Collimator 
HNF-5148, Rev. 2

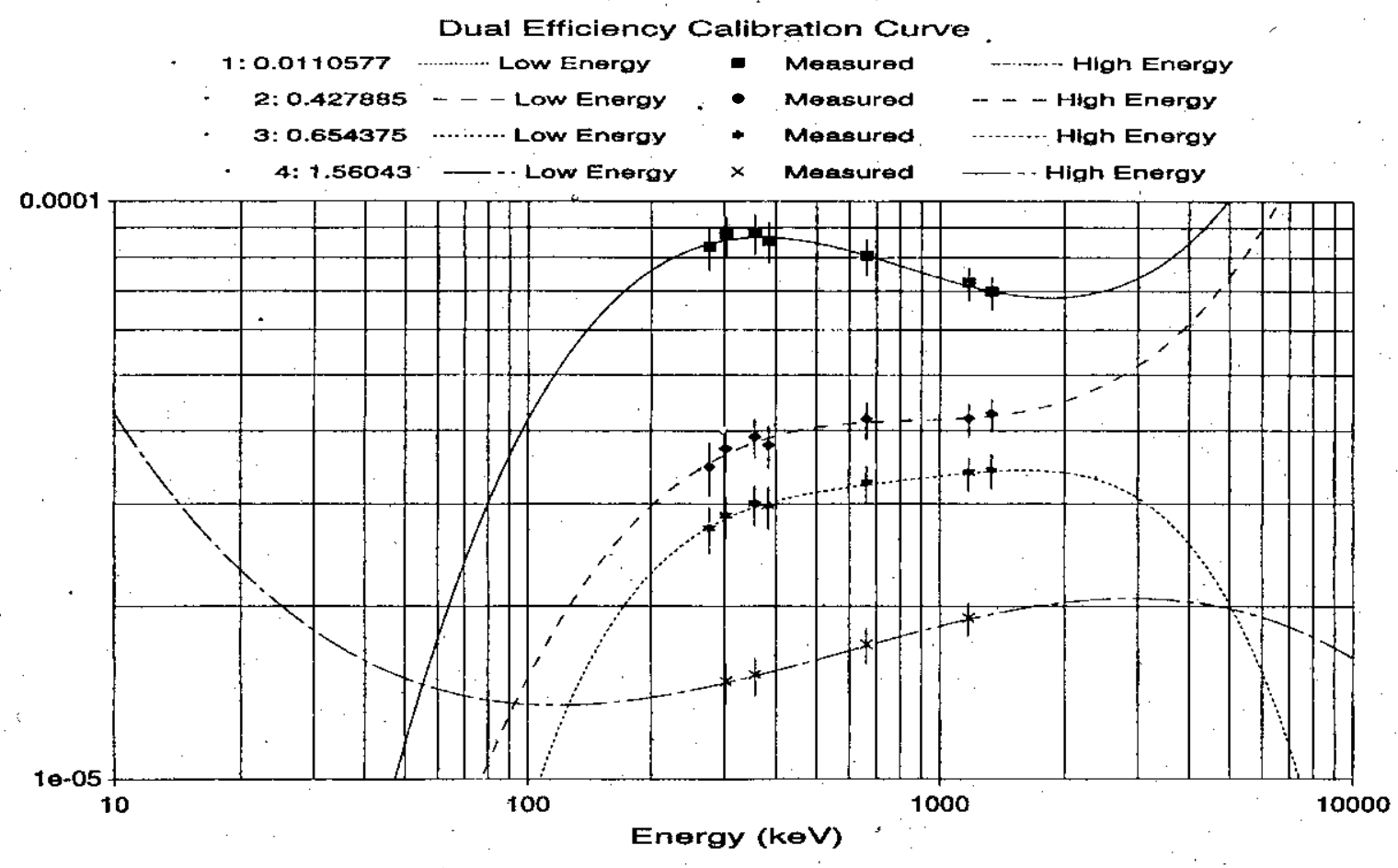

Figure 6: With Collimator

The uncertainty plots for the summed curves are seen in the following two figures, 7 and 8 . Figure 7 is the plot with no shield in front of the detector, while Figure 8 has the iron shield in the analytical path. 
HNF-5148, Rev. 2

\section{Error versus Energ}

NoShield (collimator)

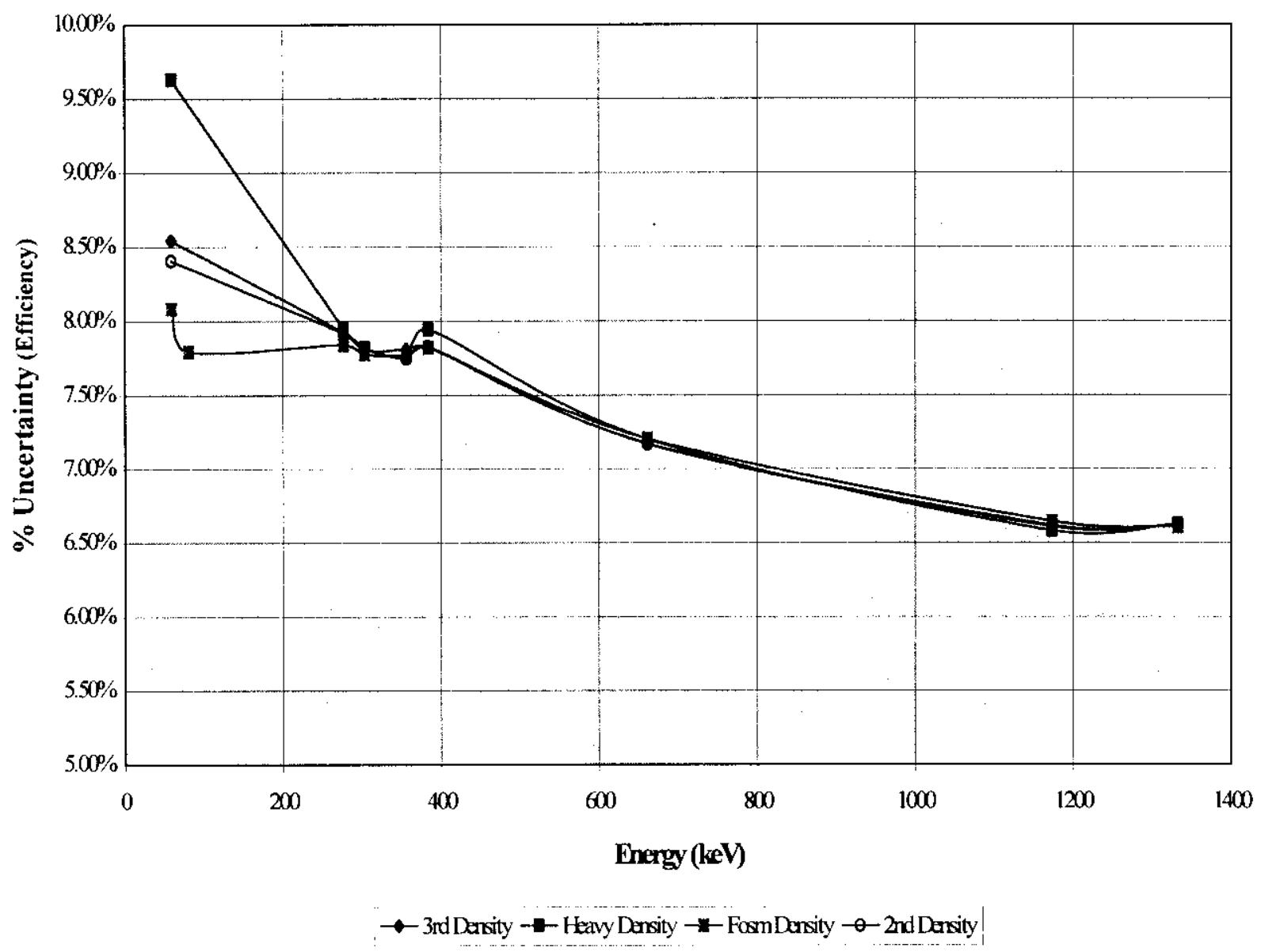

Figure 7 
Error versus Energy

With Shield (Collimator)

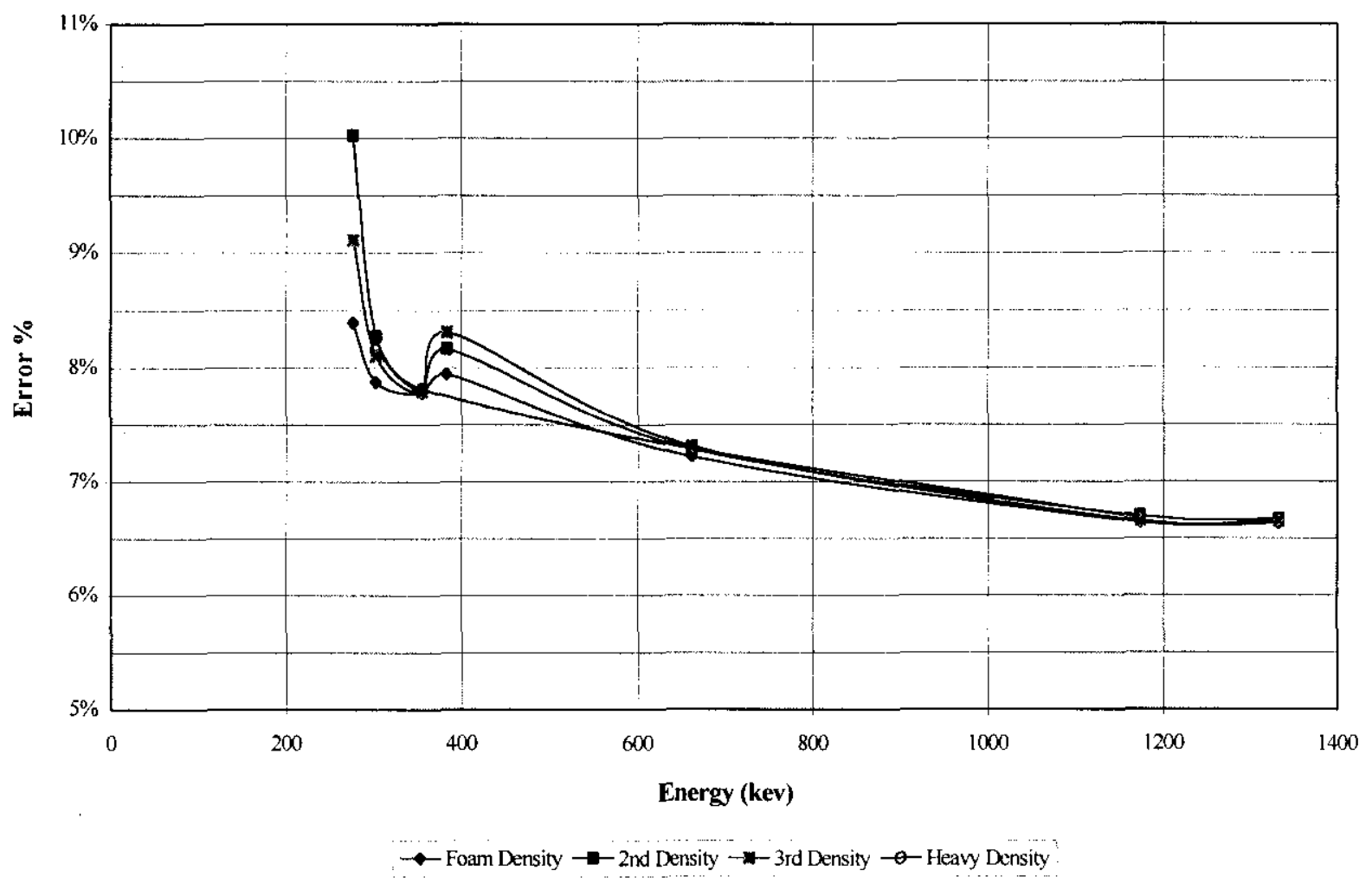

Figure 8

The uncertainty for the calibration never gets less than $6.5 \%$ for the efficiency calibration error. The slight deviations from the curve in the $385 \mathrm{keV}$ region is due to the low gamma yield of the upper Ba133 gamma line, longer counting would bring the efficiency error back to the base curve.

\section{Transmission Calibration}

The GWAS system utilizes a density evaluation method for correcting the final efficiency curves to a waste drum. The "density" correction is defined by measuring the gamma attenuation through each drum. The developed base for the correction is established during the calibration by a measure of the calibration drum with and without the shields. The program stores this data and utilizes it during actual waste drum measurements to develop the density of the waste material. The density information is then used to modify the efficiency for the waste drum and is used in the Combine All calculations. The calibration files are as follows: 
HNF-5148, Rev. 2

Transmission Calibration Report

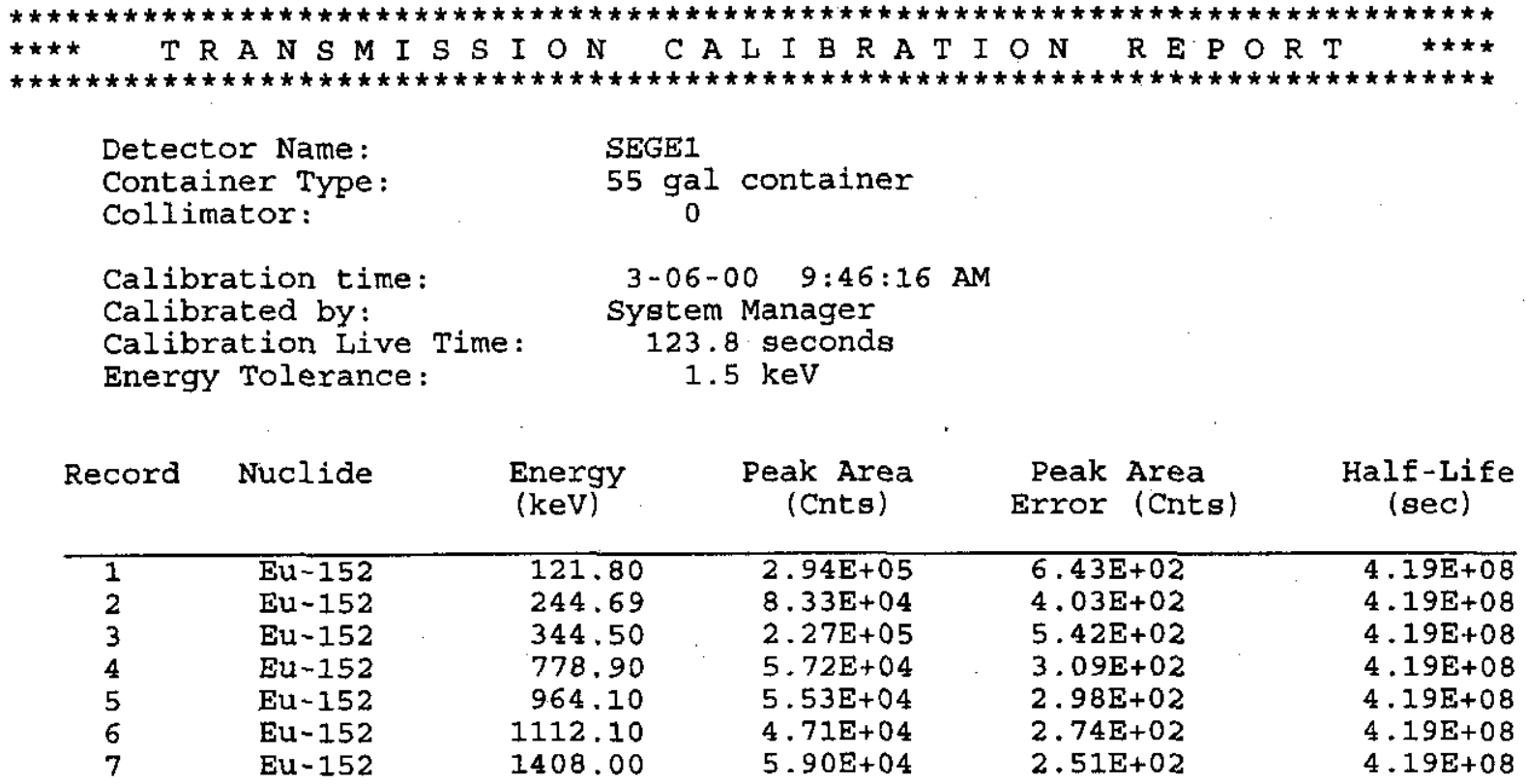

\begin{tabular}{|c|c|c|c|c|c|c|}
\hline \multirow{3}{*}{\multicolumn{2}{|c|}{ 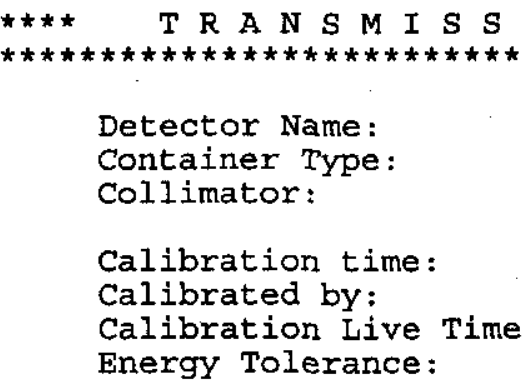 }} & $\begin{array}{l}I \underset{* * * * * * *}{O N} \\
\text { N }\end{array}$ & 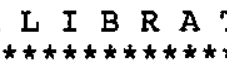 & T I O N & $\underset{\star \star \star * * \star \star \star *}{\mathrm{R}}$ & 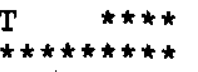 \\
\hline & & \multicolumn{2}{|c|}{$\begin{array}{l}\text { SEGE2 } \\
55 \text { gal container } \\
0\end{array}$} & & & \\
\hline & & \multicolumn{2}{|c|}{$\begin{array}{c}3-06-00 \quad 9: 46: 16 \\
\text { System Manager } \\
195.3 \text { seconds } \\
1.5 \mathrm{keV}\end{array}$} & & & \\
\hline Record & Nuclide & $\begin{array}{c}\text { Energy } \\
(\mathrm{keV})\end{array}$ & $\begin{array}{c}\text { Peak Area } \\
\text { (Cnts) }\end{array}$ & $\begin{array}{r}\text { Peak } \\
\text { Error }\end{array}$ & $\begin{array}{l}\text { Area } \\
\text { (Cnts) }\end{array}$ & $\begin{array}{l}\text { Half-Life } \\
\text { (sec) }\end{array}$ \\
\hline $\begin{array}{l}1 \\
2 \\
3 \\
4 \\
5 \\
6 \\
7\end{array}$ & $\begin{array}{l}E u-152 \\
E u-152 \\
E u-152 \\
E u-152 \\
E u-152 \\
E u-152 \\
E u-152\end{array}$ & $\begin{array}{r}121.80 \\
244.69 \\
344.50 \\
778.90 \\
964.10 \\
1112.10 \\
1408.00\end{array}$ & $\begin{array}{l}1.90 \mathrm{E}+05 \\
5.83 \mathrm{E}+04 \\
1.66 \mathrm{E}+05 \\
4.47 \mathrm{E}+04 \\
4.31 \mathrm{E}+04 \\
3.71 \mathrm{E}+04 \\
4.68 \mathrm{E}+04\end{array}$ & \multicolumn{2}{|c|}{$\begin{array}{l}5.19 E+02 \\
3.22 E+02 \\
4.65 E+02 \\
2.81 E+02 \\
2.42 E+02 \\
2.41 E+02 \\
2.22 E+02\end{array}$} & $\begin{array}{l}4.19 E+08 \\
4.19 E+08 \\
4.19 E+08 \\
4.19 E+08 \\
4.19 E+08 \\
4.19 E+08 \\
4.19 E+08\end{array}$ \\
\hline
\end{tabular}


HNF-5148, Rev. 2

Transmission Calibration Report

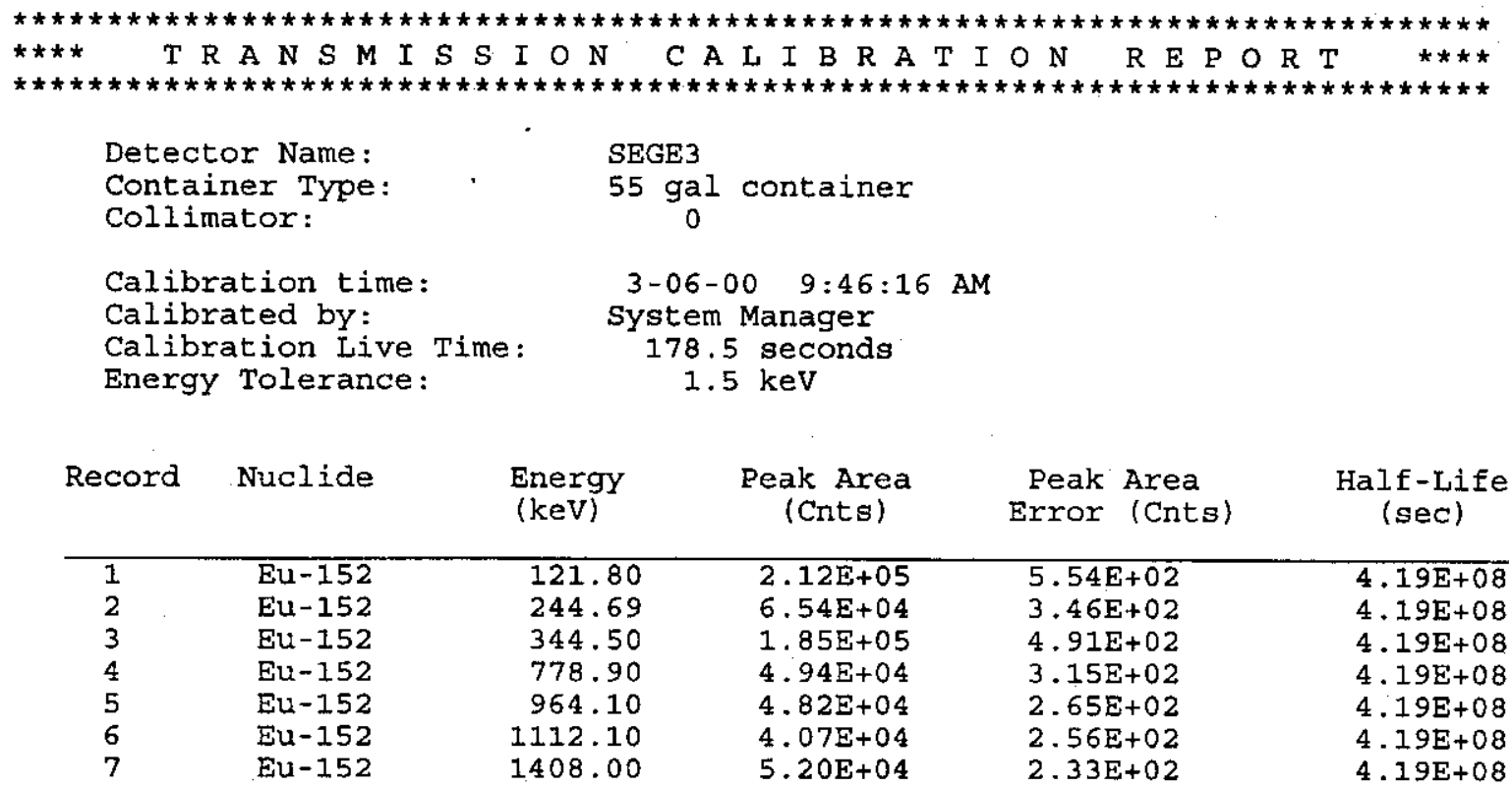

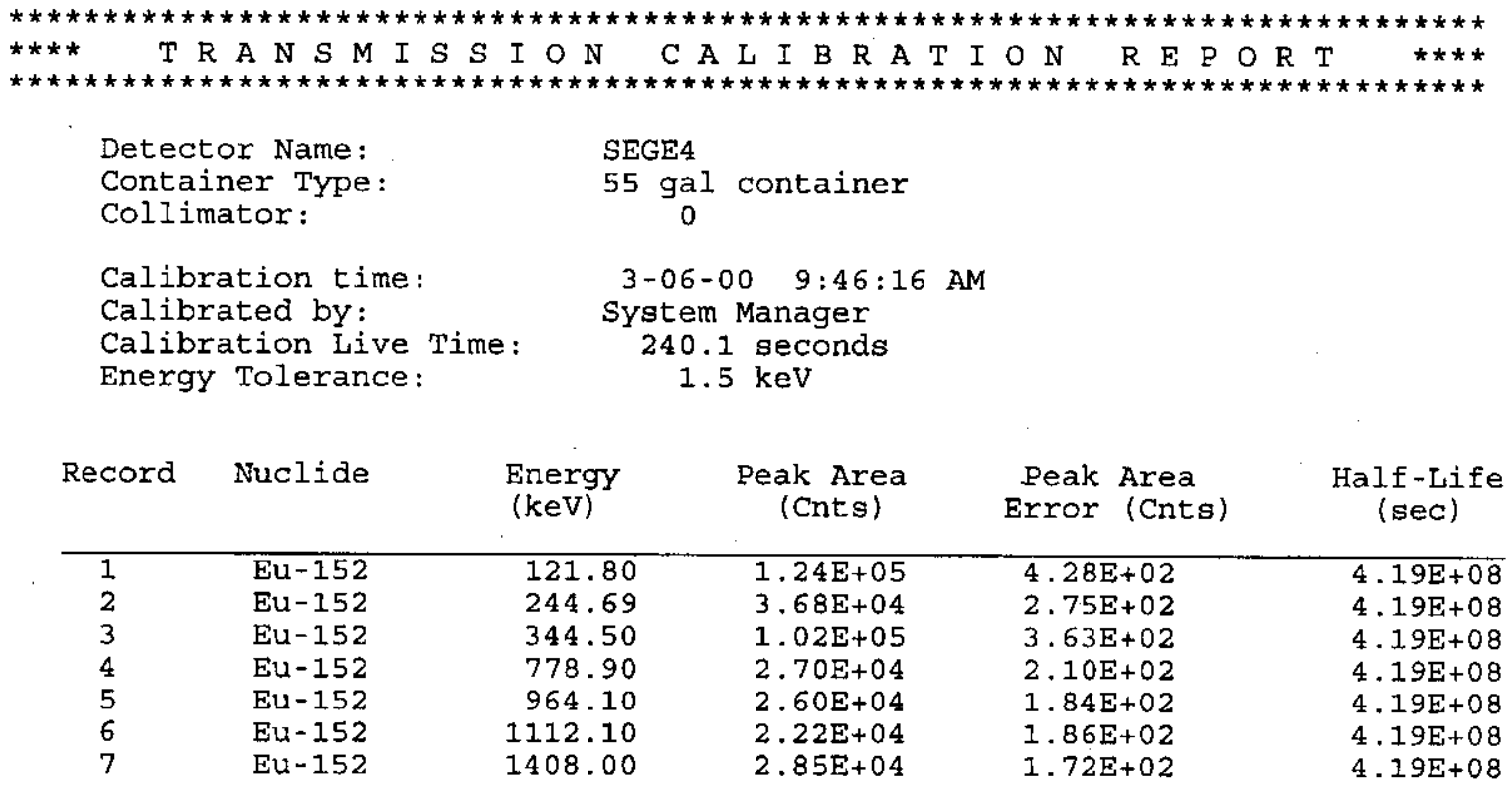


HNF-5148, Rev. 2

Transmission Calibration Report

$3-06-00 \quad 10: 06: 37 \mathrm{AM}$

Page 1

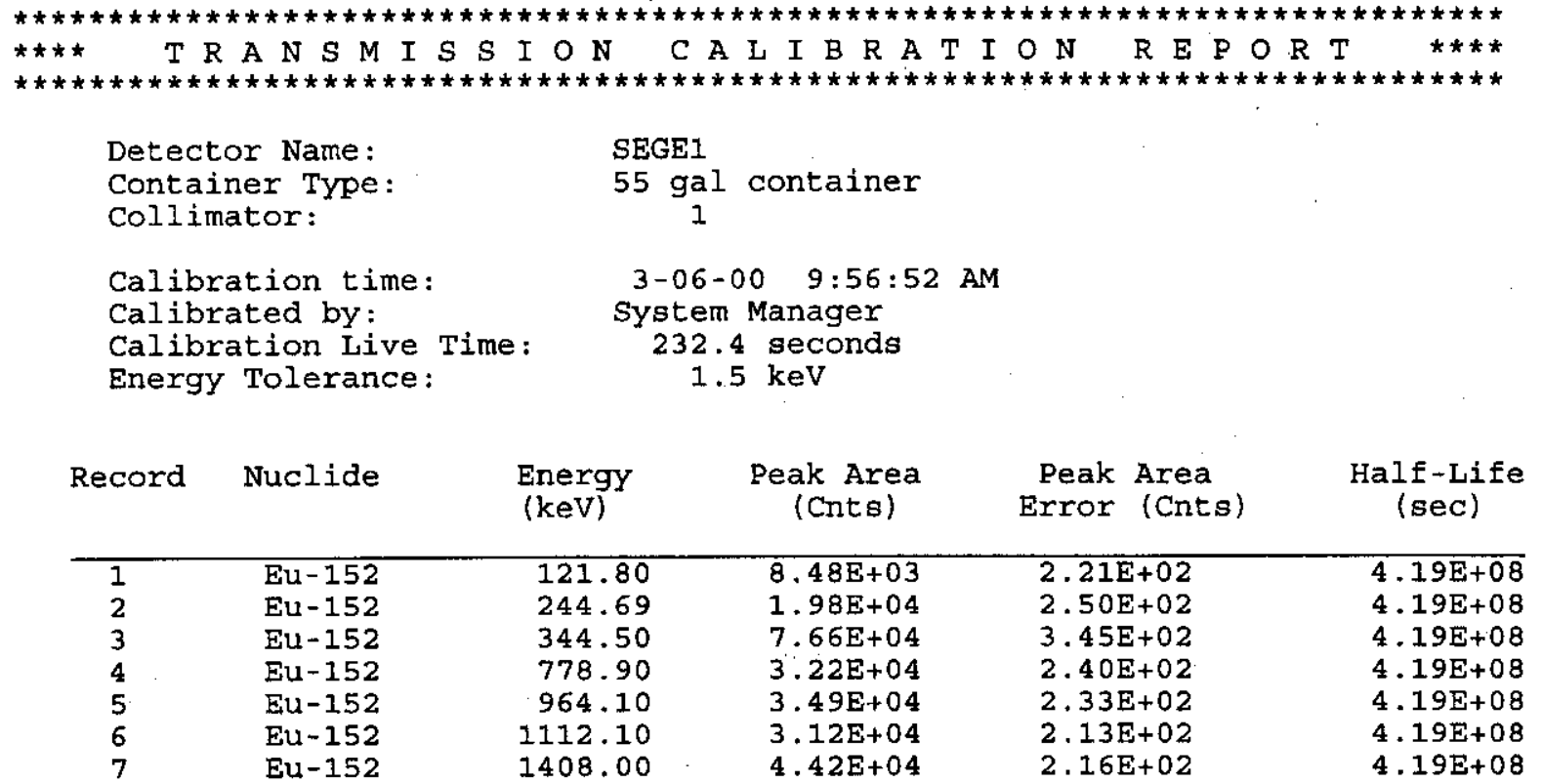

Transmission Calibration Report

$3-06-00 \quad 10: 06: 25 \quad A M$

Page 1

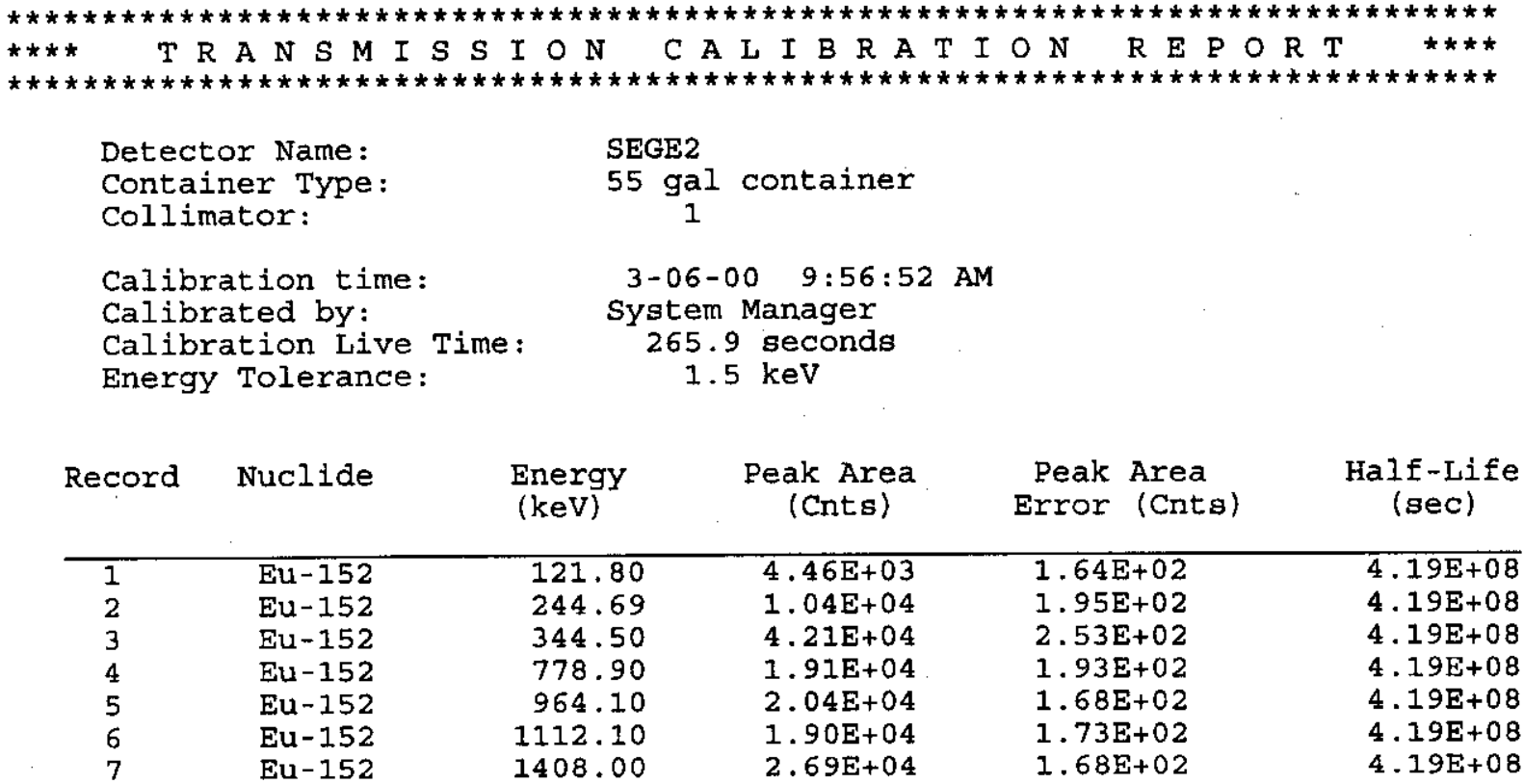


HNF-5148, Rev. 2

Transmission Calibration Report

3-06-00 10:06:10 AM

Page 1

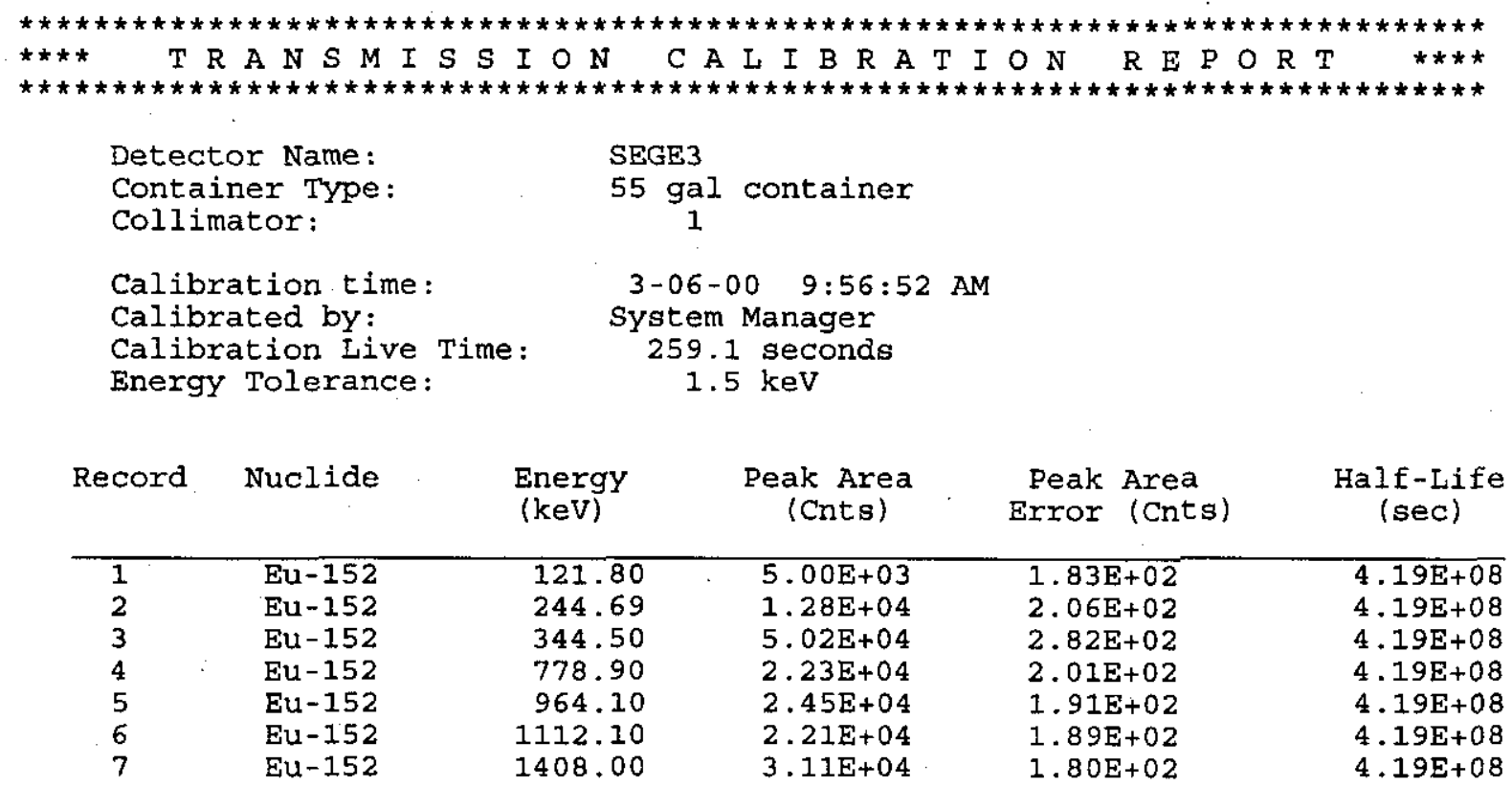

Transmission Calibration Report

3-06-00 10:05:59 AM

Page 1

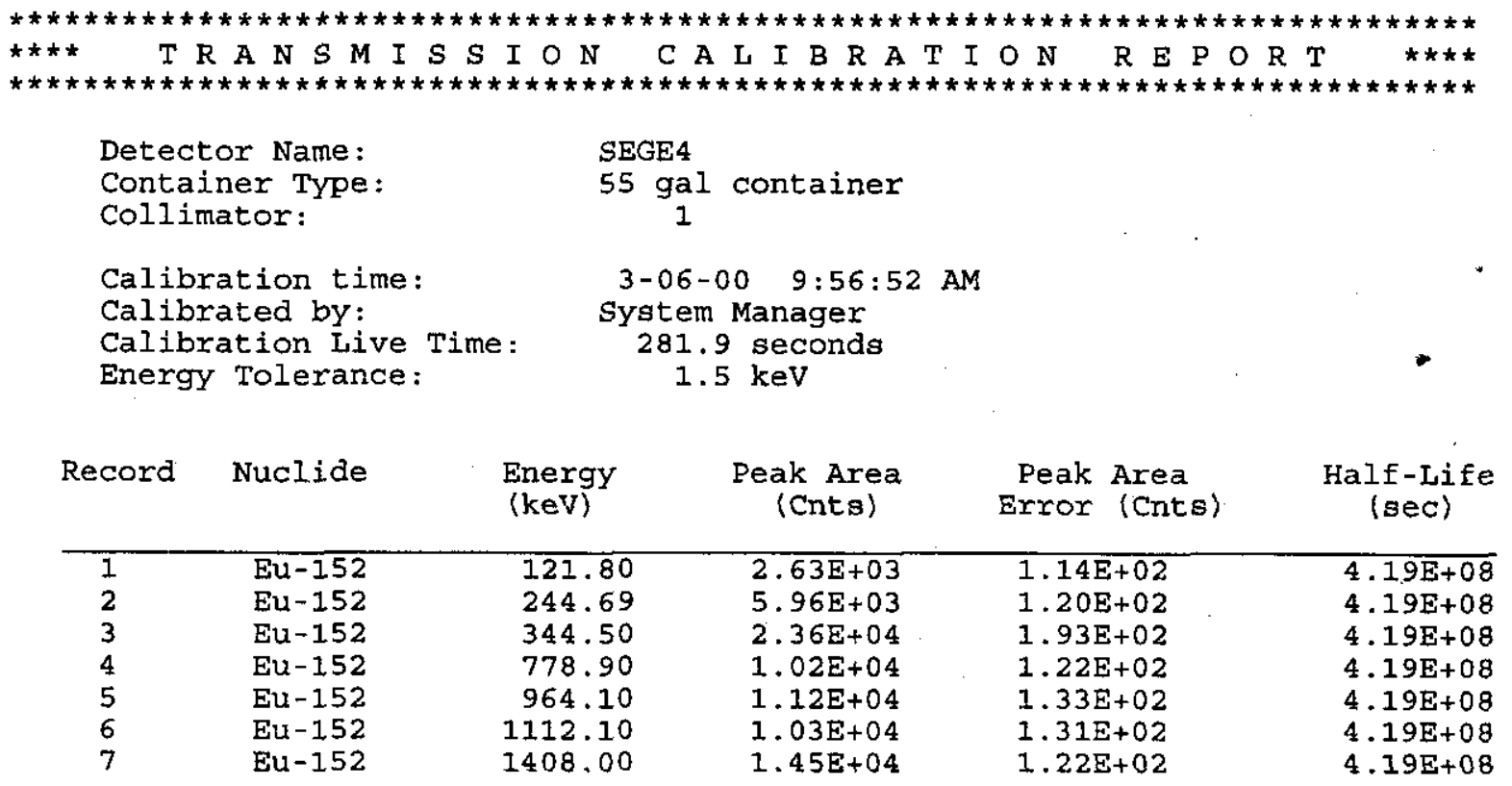


HNF-5148, Rev. 2

\section{REFERENCES}

1. TRU Control of Measuring, Testing and Data collection Equipment, WMH-400, Waste Isolation Pilot Plant (WIPP) Procedures, Section 2.4.4, Rev 3, Sub Section 2.1.2.

2. Canberra Model S431 Genie-PC Gamma Waste Assay Software, Technical Reference Manual S431-TEC, V 2.3, May 1998.

3. Quality Assurance Objectives for Nondestructive Assay at the Waste Receiving and Processing facility, HNF-4051, Rev 3.

4. Hanford Site Transuranic Waste Certification Plan, HNF-2600, Rev 2, Appendix E.

5. WRAP Gamma Energy Assay System, KEH 5369, Installation and Maintenance Manual, 2/23/96, Document \# 96048.

6. MGA: A Gamma-ray Spectrum Analysis Code for determining Plutonium isotopic abundances. Vol 1, Methods and Algorithms. NTIS-DE90013529, Lawrence Livermore National Laboratory, Livermore, Ca. April 1990.

7. Canberra Genie-PC, V2 - Advanced Topics, S400-usr, V 2.4, February 1997. 
HNF-5148, Rev. 2

\section{APPENDIX A}

\section{Calibration Configuration}

Drum Source Distribution 


\section{Q2 SYSTEM CALIBRATION AND SOURCE DISTRIBUTION}

\section{Calibration Drum Description:}

A set of four calibration matrix drums was used to determine the Q2 (Canberra GWAS) system efficiencies as a function of photon energy and source matrix density. Four $208 \mathrm{Liter}$ ( 55 gallon) drums were homogeneously loaded with the following materials and approximate densities:

1) Polyurethane foam $(0.14 \mathrm{gm} / \mathrm{cc})$

2) Soft Board (Homosote) $(0.470 \mathrm{gm} / \mathrm{cc})$

3) Particle board $(0.76 \mathrm{gm} / \mathrm{cc})$

4) Sand $(1.67 \mathrm{~g} / \mathrm{cc})$

Each calibration matrix is divided into 6 cylindrical shells, designed to simulate a homogeneous source distribution. A set of hollow tubes was mounted in each of these shells. The source tubes extended the full height of the matrix, and were mounted parallel to the center of the axis of the drum at the positions shown in the following top view diagram.

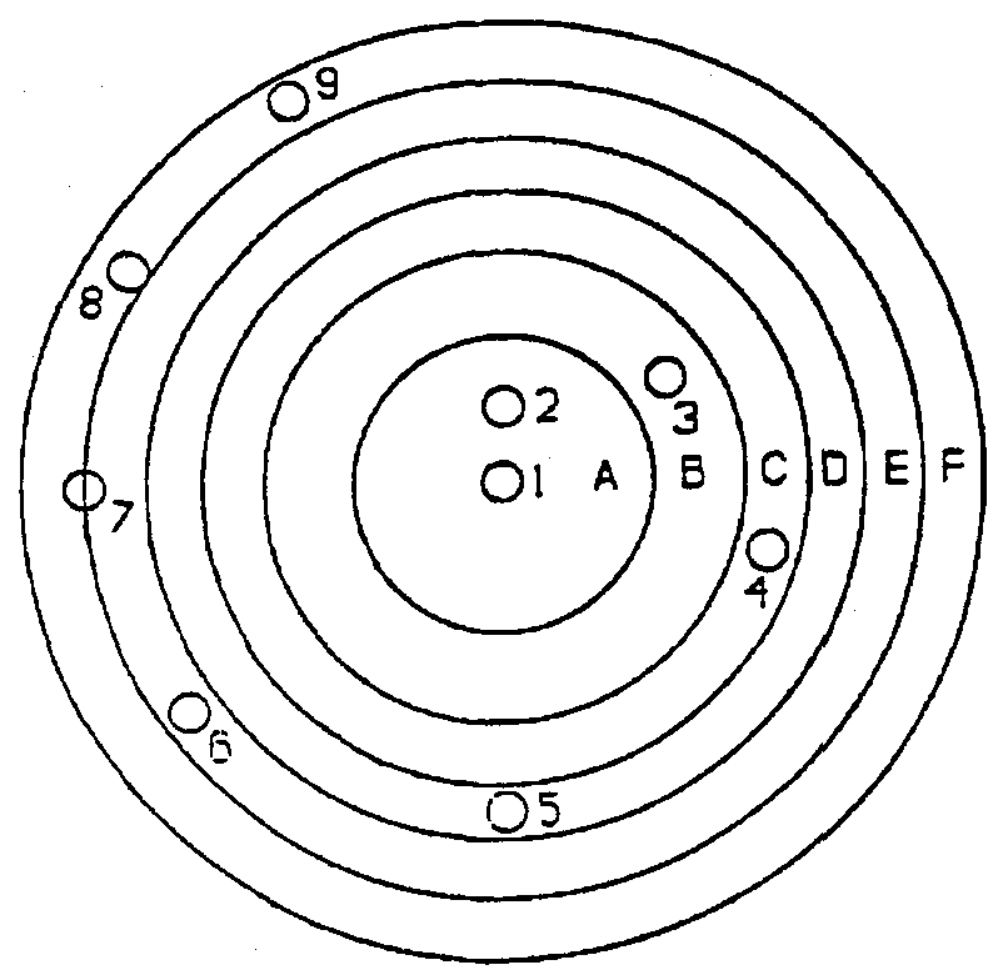


In order to simulate routine sample counting conditions during the calibration process, the drums were placed on the turntable platform and rotated at a constant speed during all the counts. The axis of rotation was perpendicular to the axis of the Q2 system detectors. In this case a line geometry source (with equal activity per unit length) positioned in a source tube provides counting results equivalent to a cylindrical shell-geometry source with the same radial distance from the center axis of the drum. Taken together, the six shells simulate a homogeneous source distribution throughout the matrix.

Each calibration drum is divided into six shells of equal volume, and labeled A, B, C, D, E, and F. The individual source tubes are numbered $1-9$. The radial distance from the drum to the center of each of these hollow source tubes is provided in the following table.

\section{Source Tube \\ Location}

1

2

3

4

5

6

7

8

9
Radius from Drum

Center (inches)
0

5.6

7.3

8.6

9.8

10.2

10.5

10.8

\section{Efficiency Calibration Theory}

Since the cylindrical shells used in this calibration have equal volumes, count rate data obtained for calibration counts with the line sources in tubes $2,3,4,5,6$, and 9 should be weighted equally for reference counting geometry efficiency determinations. Efficiency values may be calculated using the following equation:

$$
\text { Efficiency }=(\mathrm{A} 2+\mathrm{B} 3+\mathrm{C} 4+\mathrm{D} 5+\mathrm{E} 6+\mathrm{F} 9) /(\text { activity } * \text { abundance })
$$

Where

Efficiency is given in the units of counts per gamma emitted from a uniform matrix, and
A2 $=$ measured counts per second (cps) with the line source in tube 2 (shell A)
B3 = measured cps with the line source in tube 3 (shell B) 
HNF-5148, Rev. 2

$\mathrm{C} 4=$ measured cps with the line source in tube 4 (shell C)

D5 = measured cps with the line source in tube 5 (shell D)

$\mathrm{E} 6=$ measured cps with the lime source in tube 6 (shell E)

F9 $=$ measured cps with the line source in tube $9($ shell F)

Activity $=$ decay corrected activity of the calibration source. 
HNF-5148, Rev. 2

\section{APPENDIX B}

\section{Source Certificates}

B-1 


\section{Calibration Certificates}

The following certificates have been scanned from the originals, only one source leak page will be evident as it is a copy on the backs of each certificate. The certificates will be in two groups, one being the calibration sources and the second being the verification and daily check sources. In each set the stated uncertainty is at the $3 \sigma$ level.

\section{GWAS Calibration Source Set}

A matched set of six calibrated line sources is used to perform the energy, full-width-at-halfmaximum (FWHM), and the four efficiency calibrations.

\section{Calibration Source Certificate File}

The GWAS efficiency calibration requires the generation of a certificate file containing the total activity of the line sources, expressed as the number of gammas per second for each gamma line used. This is just the sum of the isotopic activities, multiplied by the abundance (branching ratio) for each of the gamma lines.

The current gamma rates are calculated from the current date and time and the reference date and time.

The total uncertainty for the line sources is calculated from the square root of the sum of the squares of the individual line source uncertainties (RMS). 


\title{
CERTIFICATE OF CALIBRATION
}

\author{
MODEL ENV4057 LINE SOURCE \\ SERIAL NUMBER D846 \\ Reference Date March 1.1996
}

\begin{tabular}{|c|c|}
\hline A tionuclide & Aetivin \\
\hline$A m-2<1$ & $147.7 \mathrm{~kg}(3.991, \mathrm{CG})$ \\
\hline Do-133 & $206.7 \mathrm{kBO}(5.587, \mathrm{Cl})$ \\
\hline $\mathrm{Ca}-137$ & $38.54 \times \mathrm{Ba}(1.042, \mathrm{Ci})$ \\
\hline $\cos \alpha$ & $38.66 \times 80\left(1.045_{;} \mathrm{Cl}\right\}$ \\
\hline
\end{tabular}

Unceraing (t)
$3.27 \%$
$3.22 \%$
$3.07 \%$
$2.80 \%$

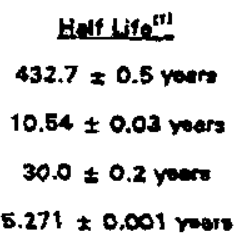

PRIMCIPLE EMSSIONS"

\begin{tabular}{|c|c|c|c|}
\hline $4 m-241$ & Iroe & $\frac{\text { Enerox fxey }}{59.6384}$ & $\begin{array}{l}\text { Ingenting } \\
35.7\end{array}$ \\
\hline $8-133$ & genmon & $\begin{array}{r}80.989 \\
278.368 \\
302.851 \\
355.999 \\
383.841\end{array}$ & $\begin{array}{c}34.2 \\
7.09 \\
18.4 \\
62.2 \\
8.92\end{array}$ \\
\hline Cs.137 & germme & 681.660 & 85.21 \\
\hline $\cos -\infty$ & gemene & $\begin{array}{l}1173.237 \\
1332.501\end{array}$ & $\begin{array}{l}99.90 \\
89.5824\end{array}$ \\
\hline
\end{tabular}

SOURCE DESCRIPTION

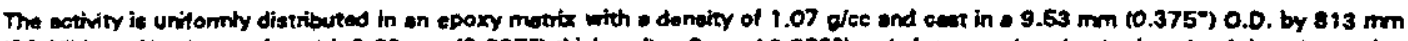

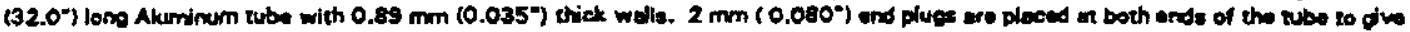
in ecivo langth of $809 \mathrm{~mm}(31.84 \%)$.

METHOD OF CALBRATION

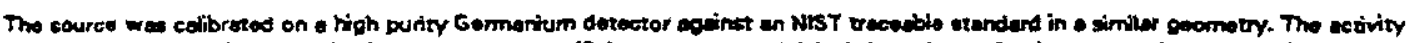

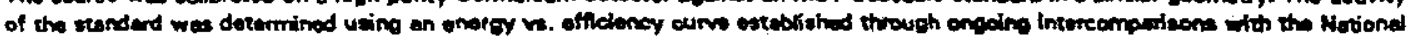

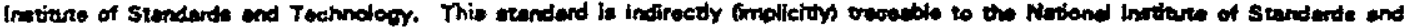
Technoloor.

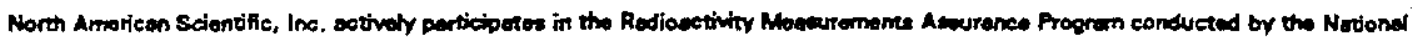

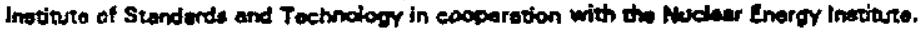

\section{Stapion

Mareh 19. 1988

BEFERENCES

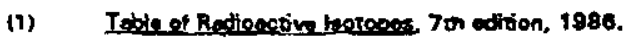

- LeAK TEST CERTIFICATION ON REVERSE -

North American Scientific, the 7435 Greenbush Ave., North Hollywood, CA 91605 (818) 5039201 Fax (818) 503-0764 


\title{
CERTIFICATE OF CALIBRATION
}

\author{
MODEL ENV4057 LINE SOURCE \\ SERIAL NUMBER D847 \\ Reference Date Match 1. 1996
}

Qedionuetide
Am-241
Bo-133
Co-137
Co-60

PRINCIPLE EMISSIONS"'

\begin{tabular}{|c|c|c|c|}
\hline & Ines & Enesoveften & Imenetio $(x)$ \\
\hline$A m-241$ & amme & 59.5364 & 35.7 \\
\hline B.-193 & gorme & $\begin{array}{r}80.989 \\
276.388 \\
302.851 \\
355.999 \\
383.841\end{array}$ & $\begin{array}{c}34.2 \\
7.09 \\
18.4 \\
62.2 \\
8.92\end{array}$ \\
\hline$C=-137$ & germe & 681.860 & 85.21 \\
\hline $\cos 60$ & garnose & $\begin{array}{l}1173.237 \\
1332.501\end{array}$ & $\begin{array}{l}99.90 \\
99.9824\end{array}$ \\
\hline
\end{tabular}

$$
\begin{gathered}
\text { Heif uits } \\
632.7 \pm 0.5 \text { years } \\
10.54 \pm 0.03 \text { vers } \\
30.0 \pm 0.2 \text { vors } \\
5.271 \pm 0.001 \text { voass }
\end{gathered}
$$

SOURCE DESCAPTION

The ecivity is uriformly distributed in on opoxy metrix with a donsity of $1.07 \mathrm{~g} / \mathrm{ec}$ and osel in a $9.53 \mathrm{~mm}\left(0.375^{\circ}\right) 0.0$. by $813 \mathrm{~mm}$

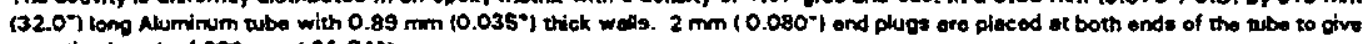
on exive length of $800 \mathrm{~mm}\left(31.84^{\circ}\right)$.

METHOD OF CALBRATION

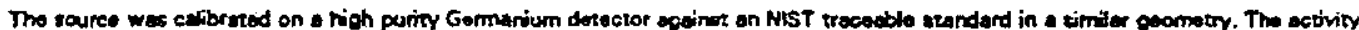

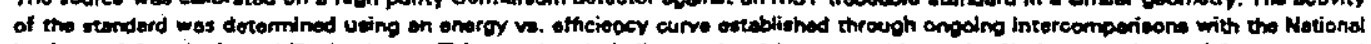

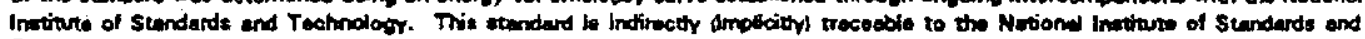
Technotoory.

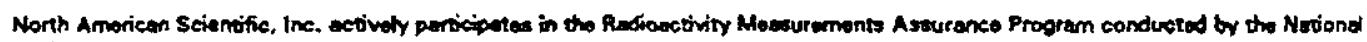
Inatiture of Stondarde and Techrology in cooporation with tho Nucloer Enargy Instituto.

$\operatorname{San} \tan$

Jay Fon, Ph.D.

Cectibretion Libaratory Monapar

BEFERENGES
Narch 19, 1998

Dote

(1)

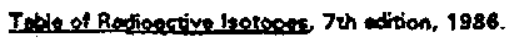

\section{- LEAK TEST CERTIFICATION ON REVERSE -}

North American Scientific, ine 7435 Greenbush kwe, Nord Hollywood, CA 91605 (818) 5039201 Fax (818) 5030764 


\title{
CERTIFICATE OF CALIBRATION
}

\author{
MODEL ENV4057 LINE SOURCE \\ SERIAL NUMBER D848 \\ Roference Date March 1.1996
}

Redionuelids
Arm-241
$80-133$
$C s-137$
$C 0-60$

Agtiviox

$150.4 \mathrm{kBg}(4.065 \mathrm{rCi})$

Tring $(t)$

Helf Lifo"in

$205.4 \mathrm{kBq}$ (5.552 $\mathrm{LCC}$ )

$3.25 \%$

$432.7=0.5$ voars

$38.27 \times 80(1.034, \mathrm{Ci})$

$3.20 \%$

$10.54 \pm 0.03$ yesm

$2.89 \%$

$30.0 \pm 0.2$ yours

$38.35 \mathrm{kBq}(1.036, \mathrm{Ci})$

$2.66 \%$

$5.271 \pm 0.001$ yoars

PRINCIPLE EMISSIONS"

\begin{tabular}{|c|c|c|c|}
\hline & Inpe & Enerore (keV) & larensity $(\%)$ \\
\hline Am-24r & gormms & 59.5364 & 35.7 \\
\hline A-133 & gammo & $\begin{array}{r}80.989 \\
276.388 \\
302.851 \\
355.999 \\
383.841\end{array}$ & $\begin{array}{c}34.2 \\
7.09 \\
18.4 \\
62.2 \\
8.92\end{array}$ \\
\hline C2-137 & gamma & 681.680 & 85.21 \\
\hline Co-60 & gormm & $\begin{array}{l}1973.237 \\
1332.501\end{array}$ & $\begin{array}{l}99.90 \\
99.9824\end{array}$ \\
\hline
\end{tabular}

SOURCE DESCRIPTION

The activity is uniformly distributod in an epoxy matrix with a donsiry of 1.07 g/ce and cest in a $3.53 \mathrm{~mm}$ (0.375\% 0.0 . by $813 \mathrm{~mm}$

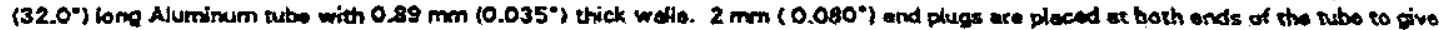
en ecive longth of $809 \mathrm{~mm}$ (31 $84 \%$.

METHOO OF CALIBRATION

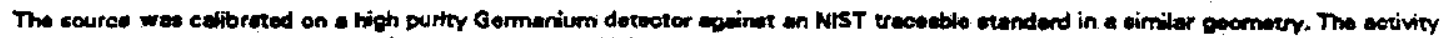

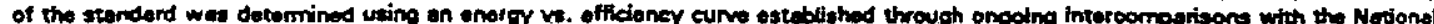

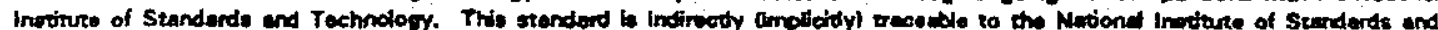
Teehnotosy.

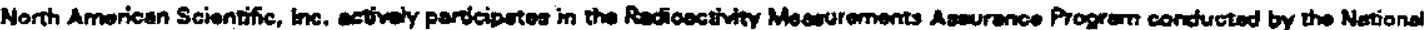
Iratitute of Sconderds and Technology in coopteretion wizh the fluchaer Energy inatinte.

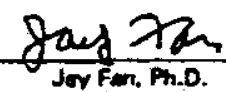

Morch 19, 1990

Caffberion Laboratory Maneger

Dote

BEEERENCES

(1)

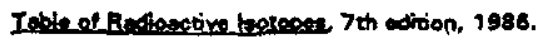

\section{- LEAK TEST CERTIFICATION ON REVERSE•}

North American Scientific, inc 7435 Greenbush Ave, North Holtywood, CA $91605 \quad$ (818) 503-9201 Fax (818) $503-0154$ 


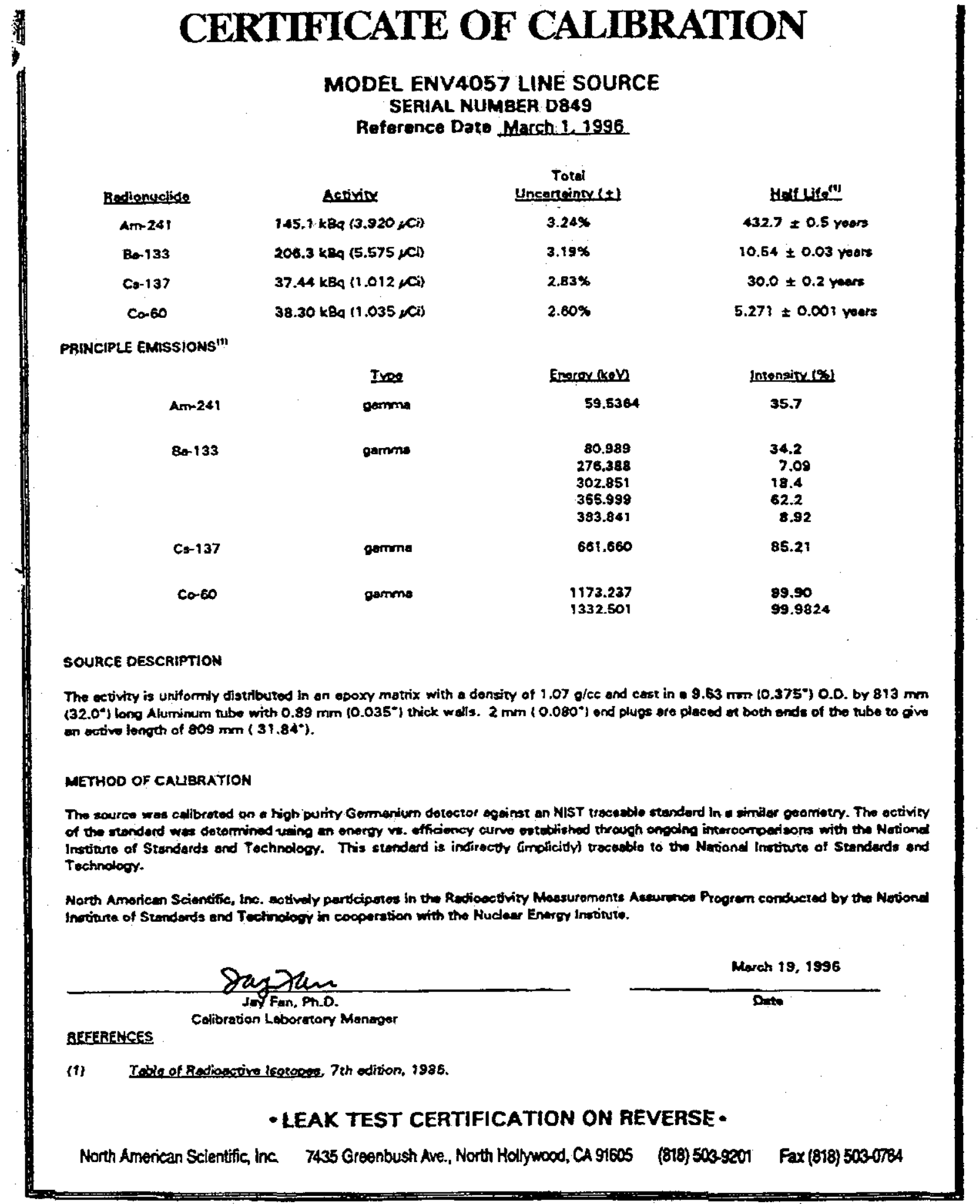


HNF-5148, Rev. 2

\title{
CERTIFICATE OF CALIBRATION
}

\author{
MODEL ENV4057 LINE SOURCE \\ SERIAL NUMBER D850 \\ Reference Date March 1.1996
}

Betioncids
Am-241
B-133
C.-137
Co-60

Acrivity
$146.4 \mathrm{kBd}(3.956, \mathrm{Ci})$
$205.5 \mathrm{kBd}(5.553, \mathrm{Cl})$
$37.39 \mathrm{kB}(1.010, \mathrm{Cl})$
$38.52 \mathrm{kBO}(1.047, \mathrm{Cl})$

roted
Uoceneine (1)
$3.28 \%$
$3.21 \%$
$3.01 \%$
$2.74 \%$

PRINCIPLE EMISSIONS'11

\begin{tabular}{|c|c|c|c|}
\hline & Ixee & Enerov (fisel) & Intengise (x) \\
\hline Am-241 & Darmons & 59.5364 & 35.7 \\
\hline Bat 133 & Dermmo & $\begin{array}{r}80.989 \\
276.388 \\
302.851 \\
355.999 \\
363.841\end{array}$ & $\begin{array}{c}34.2 \\
7.08 \\
18.4 \\
62.2 \\
8.92\end{array}$ \\
\hline C:-137 & pernma & 081.660 & 85.21 \\
\hline $\cos -60$ & gornma & $\begin{array}{l}1173.237 \\
1332.601\end{array}$ & $\begin{array}{l}99.90 \\
99.9824\end{array}$ \\
\hline
\end{tabular}

SOURCE DESCRIPTION

Tho exivity is uniformty distributed in an opoxy metrix with o donsity of 1.07 g/ec and cast in $99.53 \mathrm{~mm}(0.375 \%)$ 0.D. by $813 \mathrm{~mm}$ $\left(32.0^{\circ}\right) \mathrm{lomg}$ Alumimm tubo with $0.89 \mathrm{~mm}\left(0.035^{\circ}\right)$ thick weils. $2 \mathrm{~mm}\left(0.080^{\circ}\right)$ and plugs ere plecod et both onds of the sube to give on active longth of $809 \mathrm{~mm}(31.84 \%$.

\section{METHOD OF CALIBRATION}

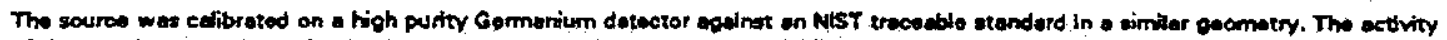

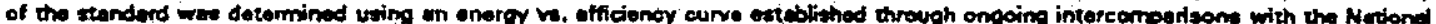

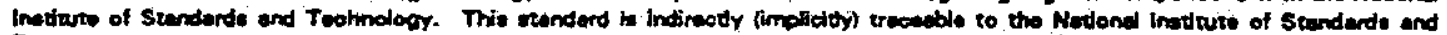
Tocturatoon.

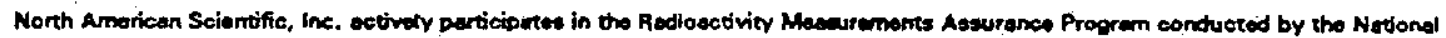
betitute of Standards and Technology in cooperetson with the Nuclaer Energy lestitute.

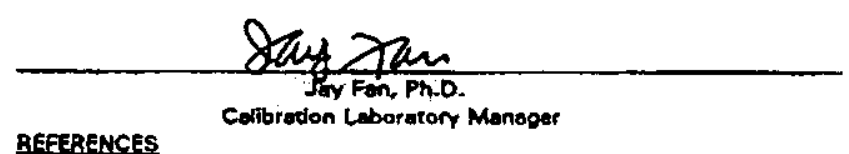

March 18, 1996

BEFERENCES

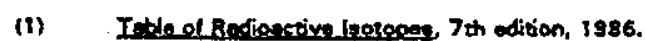

\section{- LEAK TEST CERTIFICATION ON REVERSE •}

North American Scientific, Inc. 7435 Greenbush Ave, North Hollywood, CA $9605 \quad$ (818) 5029201 Fax (818) 503-0704 


\title{
CERTIFICATE UF CALIBRATION
}

\author{
MODEL ENV4057 LINE SOURCE \\ SERIAL NUMBER D851 \\ Reforence Date March 1.1996.
}

\begin{tabular}{|c|c|}
\hline Bedienvefids & Activity \\
\hline$A m-241$ & $147.2 \mathrm{kBq} 13.977, \mathrm{Ca}$ \\
\hline Bar 133 & $205.4 \mathrm{kBO}(5.553 \mathrm{Cl}$ \\
\hline C8.137 & $38.01 \mathrm{kBq}(1.027, \mathrm{Cli})$ \\
\hline & $38.60 k$ \\
\hline
\end{tabular}

Tota
Uocentejoy $(t)$
$3.25 \%$
$3.19 \%$
$2.88 \%$
$2.63 \%$

Helf ution

$432.7 \pm 0.5$ years

$10.54 \times 0.03$ years

$30.0 \pm 0.2$ veats

$5.271 \neq 0.001$ yoers

PRIMCIPLE EMISSIONS ${ }^{\text {n }}$

\begin{tabular}{|c|c|c|c|}
\hline & Iree & Eneray axeV & Intentivy $(x)$ \\
\hline Arn-241 & gammo & 59.5364 & 35.7 \\
\hline Be-133 & gernena & $\begin{array}{r}80.989 \\
276.388 \\
302.851 \\
355.999 \\
383.841\end{array}$ & $\begin{array}{c}34.2 \\
7.09 \\
18.4 \\
62.2 \\
8.92\end{array}$ \\
\hline$C=-137$ & gemma & .661 .660 & 85.21 \\
\hline Co- 60 & commo & $\begin{array}{l}1173.237 \\
1332.501\end{array}$ & $\begin{array}{l}99.90 \\
99.9824\end{array}$ \\
\hline
\end{tabular}

SOURCE DESCRIPTION

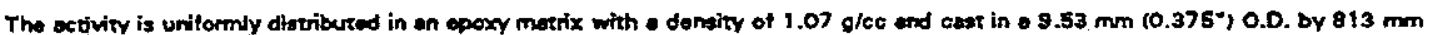
(32.0\%) long Numinum tube with $0.89 \mathrm{~mm}\left(0.035^{\circ}\right)$ thick wells. $2 \mathrm{~mm}\left(0.080^{*}\right)$ ond plugs are pleced at both onds of the tube to give on oction leneth of $809 \mathrm{~mm}\left(38,84^{\circ}\right)$.

\section{METHOD OF CALUBRATION}

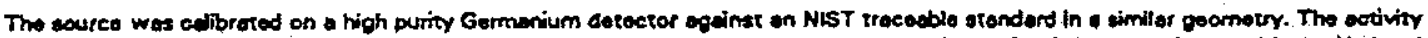

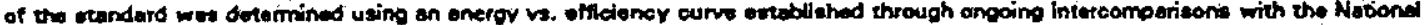

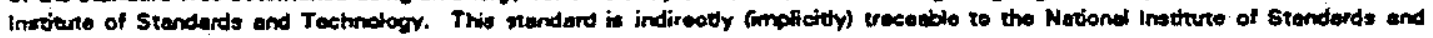
Tochnology.

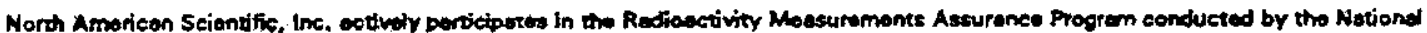
Institute of Stonderds and Tochnology in copperetion with tho Nuclear Energy institute.

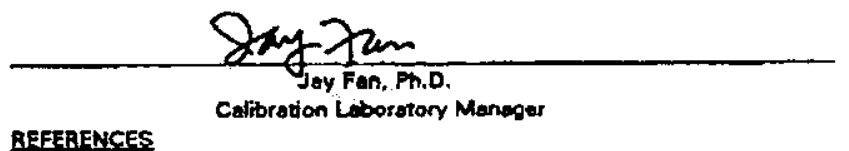

Morch 19, 1998

(1) Inde ef Redionctive lestopen, 7th odition, 1986.

\section{- LEAK TEST CERTIFICATION ON REVERSE -}

North American Scientific, inc 7435 Greenbush Ave., North Hollywood, CA 91605 (818) 503-9201 Fax (818) 503-0764 
HNF-5148, Rev. 2

\section{LEAK TEST METHODS}

1. Soak (Immersion) Test (ISOTR 4826-1979 (E) soction 2.1.3)

The source is inmersed in water or other suitable liquid at $50^{\circ} \mathrm{C}$ to at least 4 hours and the activity in the liquid measured. Acceptance limit: $0.0001 \mathrm{HCi}$ alpha, $0.001 \mu \mathrm{Ci}$ beta-gamma.

2. Immersion Test (ANSI N542-1977, Appendix A2.1.3)

The source is immersed in water at $100^{\circ} \mathrm{C}$ tor 10 minutes. The water is removed and the source cooled and rinsed using fresh water. These operations are repealed twice, boiling in the water from the provious rinsing operation. Acceptance limit: $0.0001 \mu \mathrm{Ci}$ alpha. $0.005 \mu \mathrm{Ci}$ beta-gamma for all the water collected.

\section{Wipe (Smear) Test (ANSI N542-1977, Appendix A2.1.1)}

All external surfaces of the source are wiped with a piece of fiter paper or other absorbent material which has been moistened with an appropriate solvent and the activity removed is measured. Acceptance limit: $0.0001 \mu \mathrm{Ci}$ aipha, $0.001 \mu \mathrm{Ci}$ beta-gamma.

4. Leak Test Not Applicable

For sources with no covering or a delicate covering over the radioactive portion or gas standards and sources, the inactive portions or containment vessel are wipe tested as in Method 3 above. Acceptance limit: $0.0001 \mu \mathrm{Cl}$ alpha, $0.001 \mu \mathrm{Cl}$ beta-gamma.

5. Other

\section{LEAK TEST CERTIFICATION}

The standard was leak tested in accordance with Leak Test Method 3 as described above. The removable activity was determined to be less than 0.001 beta-gamma and $0.0001 / \mathrm{Ci}$ alpha. This leak test should be performed every six months or as required by a specific NRC or Agreement State License.

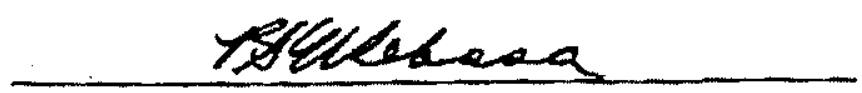

Health Physics

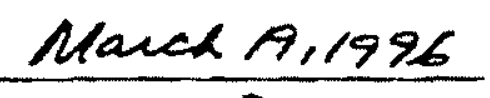

Date 
HNF-5148, Rev. 2

Calibration check and daily control drum sources.

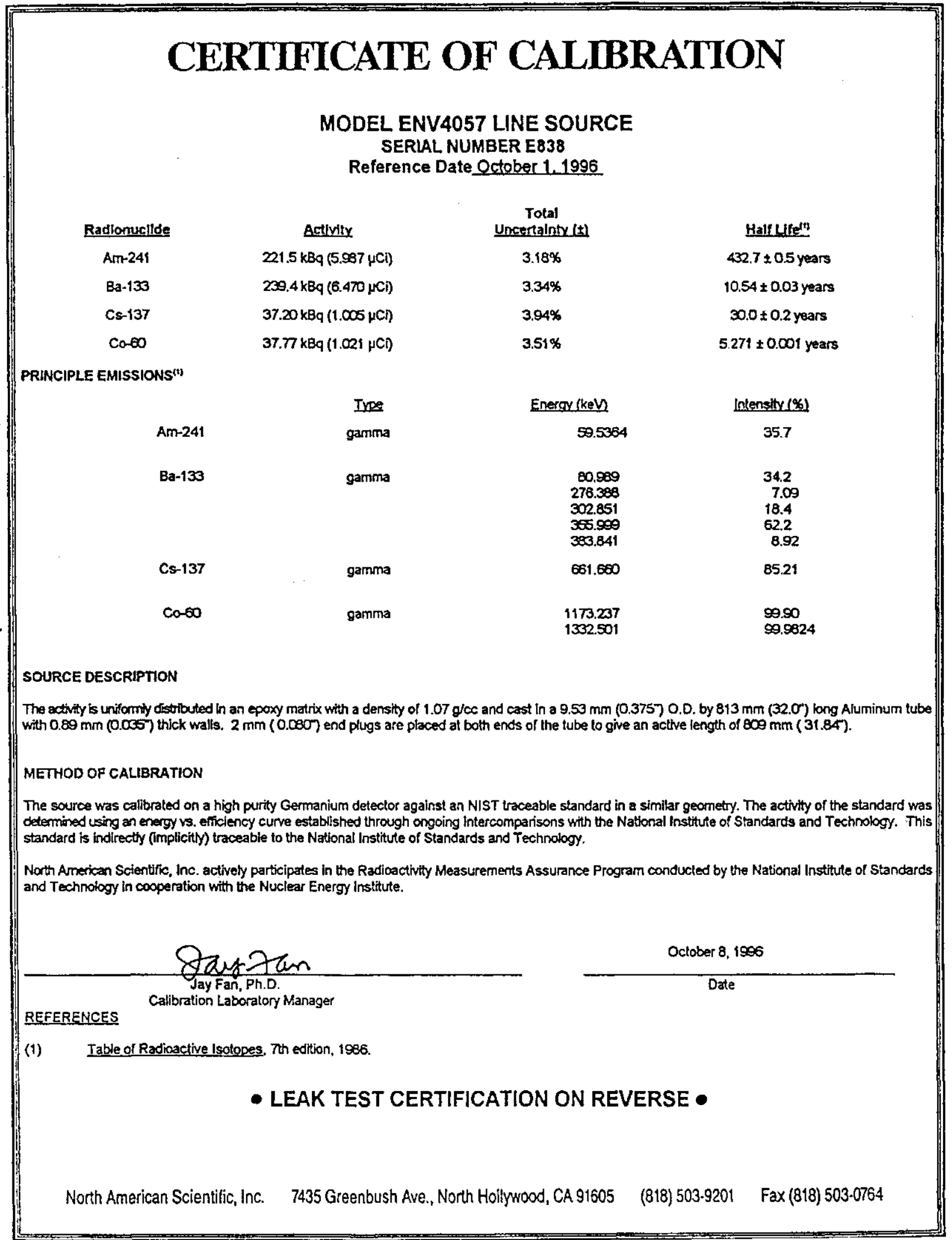


HNF-5148, Rev. 2

\title{
CERTIFICATE OF CALIBRATION
}

\author{
MODEL ENV4057 LINE SOURCE \\ SERIAL NUMBER E839 \\ Reference Date October 1. 1996
}

Radionuclide
Am-241
Ba-133
Cs-137
Co 60

PRINCIPLE EMISSIONS")

Am-24: gamm

Ba-133

Cs -137

$\cos \infty$
Activity

$220.3 \mathrm{kBq}(5.953 \mu \mathrm{C})$

$242.9 \mathrm{kBq}(6.564 \mu \mathrm{Ci})$

$36.95 \mathrm{kBq}(998.7 \mathrm{nCi})$

$37.40 \mathrm{kBq}(1.012 \mu \mathrm{Ci})$
Total

Uncertainfy!s

$3.20 \%$

$3.5 \%$

$4.04 \%$

$3.00 \%$
HaifLLife?

$402.7 \pm 0.5$ years

$10.54 \pm 0.03$ years

$300 \pm 0.2$ years

$5,271 \pm 0,001$ years

SOURCE DESCRIPTION

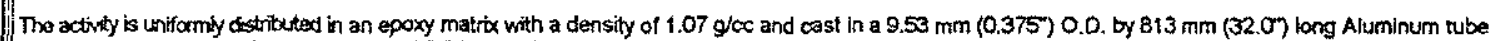
wits $0.88 \mathrm{~mm}(0.035$ ) thick walts. $2 \mathrm{~mm}$ (O.0eC) end plugs are placed al both ends of the tube to give an active length of $809 \mathrm{~mm}$ ( 31.84 ).

METHOD OF CALIBRATHON

The source was calibrated on a high purity Gemanium detector against an NIST traceable standard In a similat geometry. The activity of the standard was deterrined using an energy vs. eniciency curve established through ongoing intercomparisons with the National Institute of Standards and Technology. This istandard is indirectly (implicity) traceable to the National institute of Standards and Technology.

Noth Arberican Scientific, Inc. actively participotes in the Radioactivity Measurements Assurance Program conducted by the National institute of Standards and Technology in cooperation with the Nuclear Energy Institute.

$\operatorname{sent} 7 \operatorname{ann}$

Jaytan, Ph.D.

Energy (keply

Hiensity (\%)

36.7

80.909
276.388
302.851
355.909
333.841

342

7.09

62.2

8.92

661.660

85. 21

1173,237

9.90

99.9824

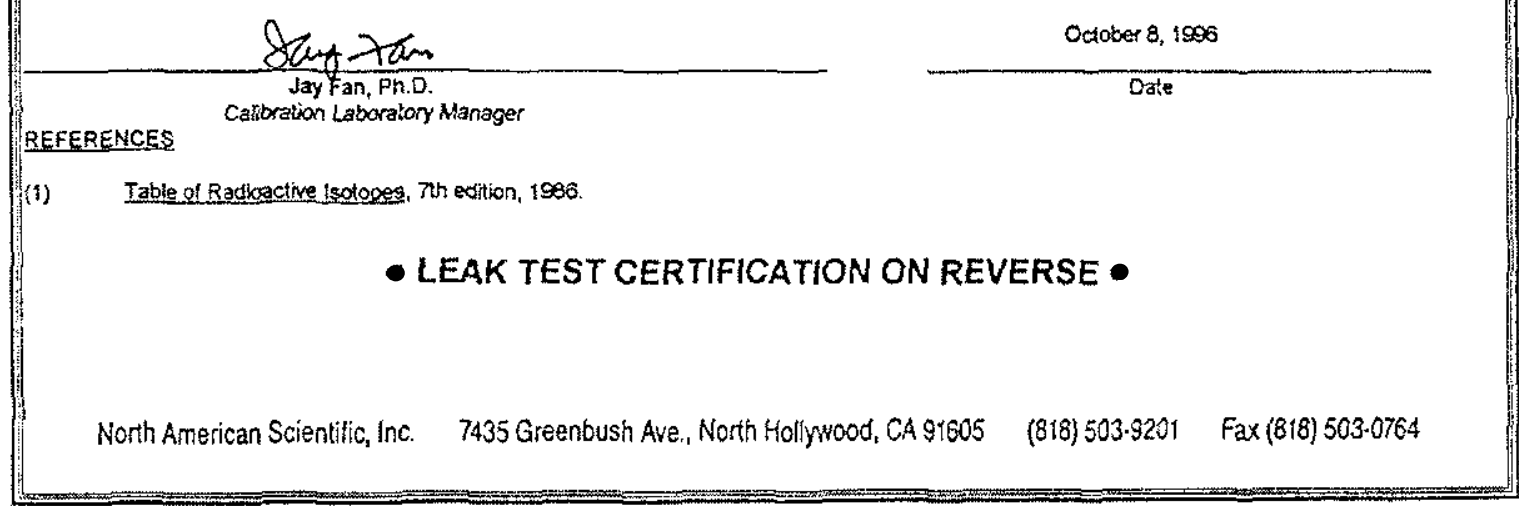


HNF-5148, Rev. 2

\section{CERTIFICATE OF CALIBRATION}

\section{MODEL ENV4057 LINE SOURCE}

SERIAL NUMBER E840

Reference Date October 1.1996

Radionuclide
Am.241
Ba- 133
Cs. 137
Co-50

PRINCIPLE EMISSIONS")

Arr-241 gamm

Ba-133

Cs-137

Co- 0
Activity

$222.8 \mathrm{kBq}(6.022 \mathrm{fCi})$

$240.8 \mathrm{kBq}(6.509 \mathrm{\mu Ci})$

$37.08 \mathrm{kBq}(1.002 \mu \mathrm{Ci})$

$36.83 \mathrm{kgq}$ ( $(005.5 \mathrm{nCi})$
Total

Uncertainly (t)

$3.17 \%$

$3.32 \%$

$3.81 \%$

$3.41 \%$

Eneroy (kev)

59.5364

80.909

276.388

302.851

350.900

383.841

661.600

1173.237

1332.501
Hair LLife $\mathrm{e}^{\text {it }}$

$432.7 \pm 0.5$ years

$10.54 \pm 0.03$ years

$30.0 \pm 0.2$ years

$5.271 \pm 0.001$ years

\section{SOURCE DESCRIPTHON}

The actinty is unifocaly distributed in an epoxy matrix with a density of $1.07 \mathrm{~g} / 0 \mathrm{c}$ and cast in a $9.53 \mathrm{~mm}(0.375)$ O.D. by $813 \mathrm{~mm}$ (32.0\%) long Aluminum tube with $0.80^{\mathrm{m}}\left(0.0055^{\circ}\right)$ thick walls. $2 \mathrm{~mm}$ ( $\left(0,080^{\circ}\right)$ end plungs are placed at both eno's of the tube to give an active length $01800 \mathrm{~mm}(31.84)$.

METHOD OF CALIBRATION

The source was calibrated on a high purity Germanium detector against an NIST tracable standard in a similar geometry. The activity of the standard was determined using an energy vs. effieiency curve established through ongoing intercomparisons with the National Institute of Standards and Technology. This standard is indirectly (implicith) traceable to the National Institute of standards and Fechnology.

Noth Atmerixan Scientific, Inc. actively participates in the Radicacthity Measurements Assurance Program conducted by the National institute of Standards and Technology in cocperation with the Nuctear Energy Institute.

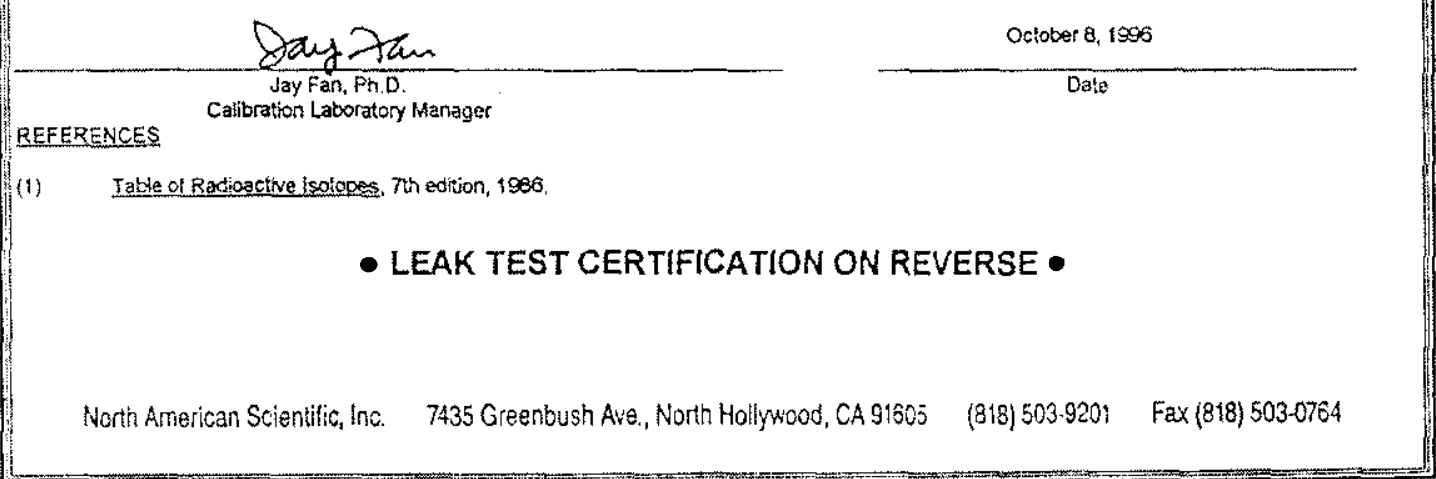


HNF-5148, Rev. 2

\section{CERTIFICATE OF CALIBRATION}

\section{MODEL ENV4057 LINE SOURCE}

SERIAL NUMBER E841

Reference Date October 1.1996

Radionustide
Am-24i
Ba-133
Cs-137
Co- $\infty$

PRINCIPLE EMISSKON\$

$\begin{array}{cc}\text { An-241 } & \text { Tyza } \\ \text { gamma } & \text { gamma }\end{array}$

Cs-137

$\cos 60$
Activity

$223.7 \mathrm{kBq}(6.046 \mu \mathrm{Cl})$

$240.6 \mathrm{kBq}\{6.503 \mu \mathrm{Cl})$

$37.18 \times 8 q q(1.005 \mu \mathrm{Ci})$

$36.9 \mathrm{kBq}(921.5 \mathrm{nCi})$ gamma

Total
Uncertainty $1 \pm 1$
$3.18 \%$
$3.33 \%$
$3.89 \%$
$3.48 \%$

Enersyikela

59.5364

80.509

276.383

355.909

383.841

51.560

1173.237

1332501
Haly Llfe $\mathrm{e}^{(n)}$

$432.7 \pm 0.5$ years

$10.54 \geq 0.03$ years

$30.0 \pm 0.2$ years

$5.271 \pm 0.001$ years

intersity (\%)

35.7

34.2

7.09

18.4

6.2.

85.21

$9 . \infty$

99.9824

SOURCE DESCRUPTION

The activity is uriformly stributed in an epoxy matrix with a density of $1.07 \mathrm{~g} / \mathrm{c}$ and cast in a $9.53 \mathrm{~mm}\left(0.375^{\circ}\right) 0.0$. by $813 \mathrm{~mm}$ (32.07) long Aluminum tube with $0.89 \mathrm{~mm}\left(0.035^{\circ}\right)$ thick walls, $2 \mathrm{~mm}\left(0.030^{\circ}\right)$ end plugs ate placed at both ends of the tube to give an active length of $800 \mathrm{~mm}$ ( 31.84$)$ ).

METHOD OF CALIBRATON

The source was calibrated on a high purity Germanlum delectox acainst an NIST traceable standard in a similar geonetry. The activity of the standard was determined using an energy ys. efriciency curve established through ongoing intercomparisons with the National institure of Standards and Tecinglogy. This standard is indirectly (implicitly) traceable lo the National Institute of Standards and Technology.

Noth Anerican Stientific, Ine. actively participates In the Radicactivity Measurements Assurance Program conducted by the National institute of Standards and Technology in cooperation with the Nuclear Energy Institute.

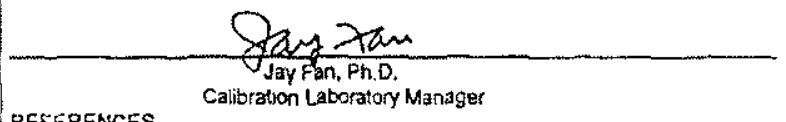

October 8,1905 REFERENCES

(1) Table of Radigactwe Isotopes, the edition, 1986

- LEAK TEST CERTIFICATION ON REVERSE •

North American Scientilic, Inc. 7435 Greenbush Ave., North Hollywood, CA $91605 \quad(818) 503.9201 \quad$ Fax (818) 503-0764 
HNF-5148, Rev. 2

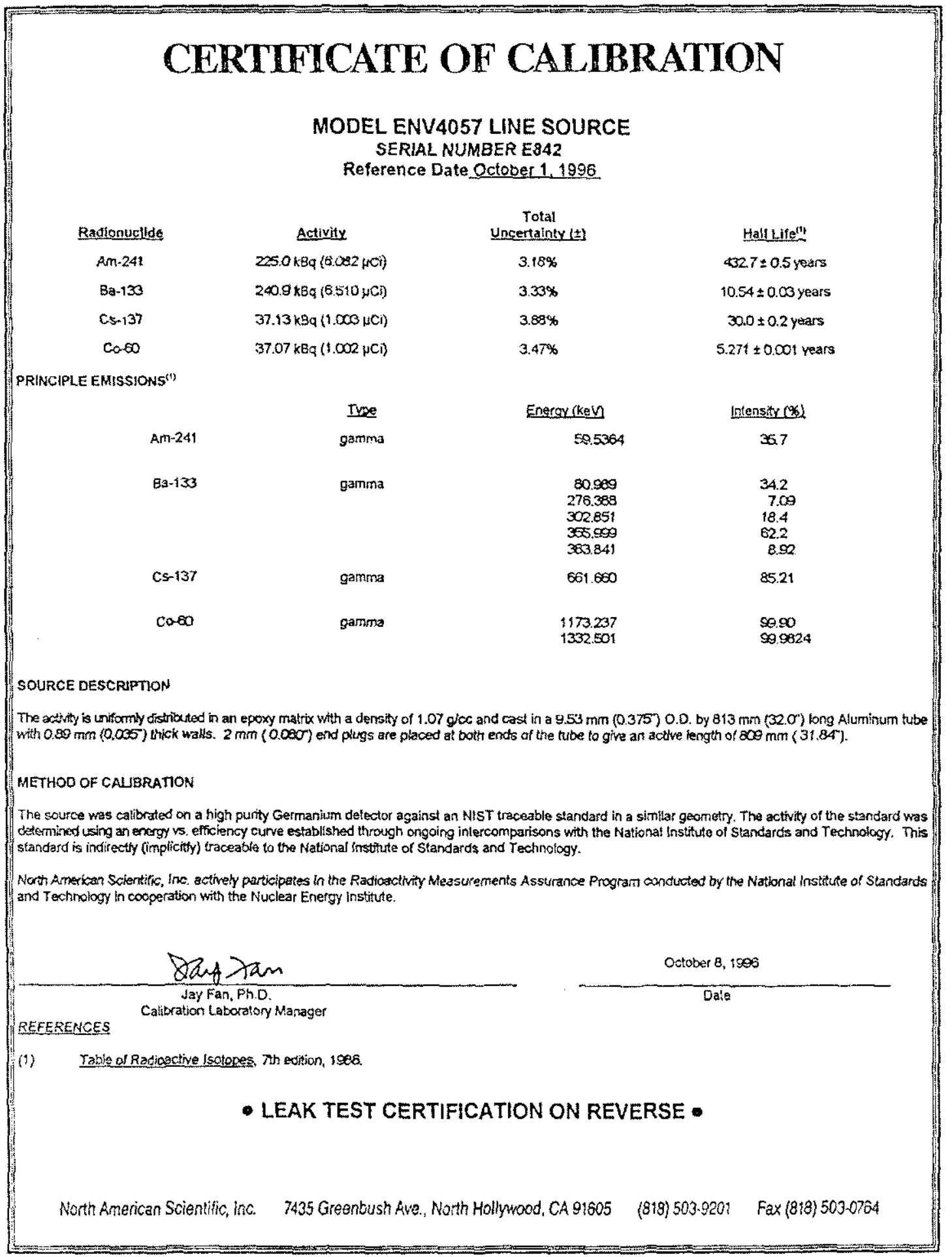


HNF-5148, Rev. 2

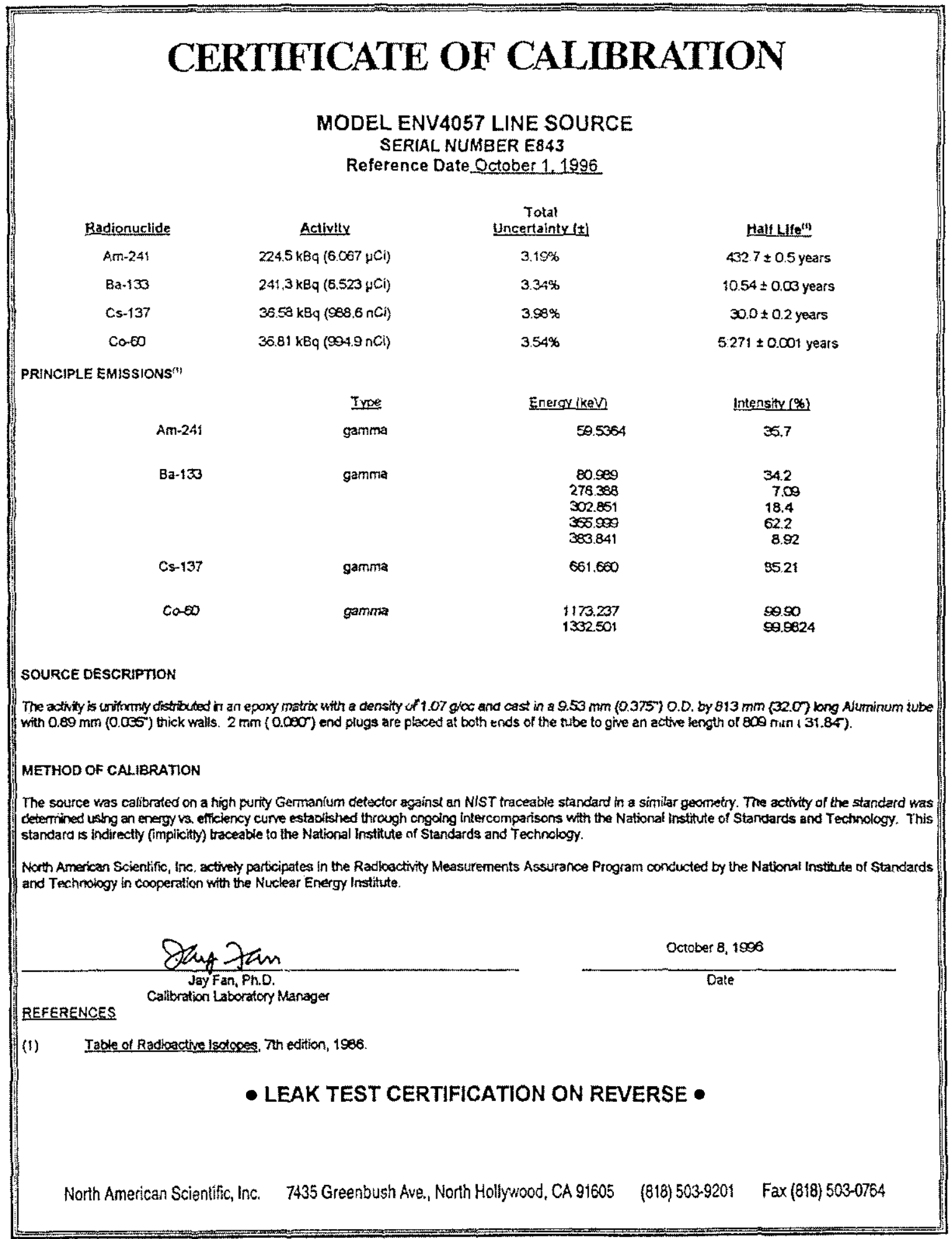


HNF-5148, Rev. 2

\section{APPENDIX C}

GWAS Detectors

Specifications

C-1 
HNF-5148, Rev. 2

\section{$\triangle$ CAMBerRA}

DETECTOR SPECLFICATION AND PERFORMANCE DATA

rcifications

DETECTOR MODEL GC1018S

SERIAL NUMBER

3963626

CRYOSTAT MODEL $\quad$ 7935-7S

PREAMPLIFTER MODEL _2002CSL

The purchase specification and therefore the warranted performance of this detector are as follows:

Active Volume

(Electric cooling may degrade performance by as much as $10 \%$.)

Resolution

- ce Relative Efficiency $10 \%$

1.8
$\mathrm{keV}$ (FWHM) at $1.33 \mathrm{MeV}$

$0.70 \quad \mathrm{keV}$ (FWHM) at $122 \mathrm{keV}$ $\mathrm{keV}$ (FWTM) at

Peak / Compton __ : 1 Cryostat well diameter mm Cryostat well depth $\mathrm{mm}$ Cryostat description if special

Physical Characteristics

Geometry Closed-end coaxial

Diameter $45.5 \mathrm{~mm}$
Length $\frac{30}{30} \mathrm{~mm}$

Distance from window $\mathrm{mm}$

Active Volume _ $\mathrm{mm}$
Well Depth
Well Diameter
$\mathrm{mm}$

\section{Electrical Characteristics}

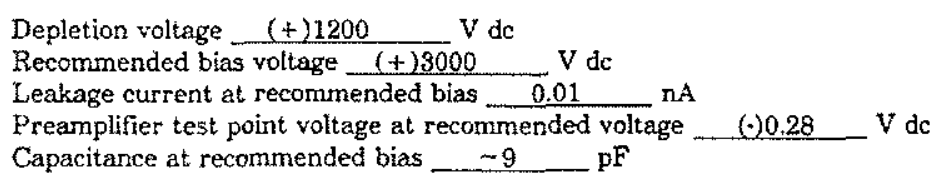

\section{Resolution and Efficiency}

With amplifier time constant of _4_ microseconds

\begin{tabular}{|c|c|c|c|c|c|}
\hline Isotope & ${ }^{57} \mathrm{Co}$ & ${ }^{60} \mathrm{Co}$ & & & \\
\hline Energy (KeV) & 122 & 1332 & & & \\
\hline FWHM (KeV) & 0.69 & 1.74 & & & \\
\hline FWTM (KeV) & 1.27 & 3.25 & & & \\
\hline Peak/Compton & & $38.0: 1$ & & & \\
\hline Rel. Efficiency \% & & 10.0 & & & \\
\hline
\end{tabular}

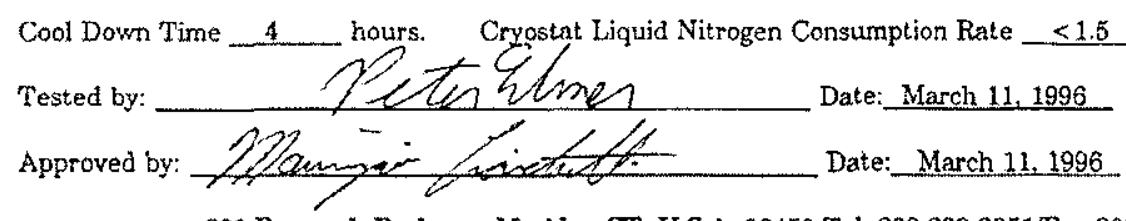

800 Research Parkway, Meriden CT. U.SA 06150 Tel 203-238-2351/Fax 203-235-1347 
HNF-5148, Rev. 2

Detector sent to Canberra for repair.

\section{A CAN BERRA DETECTOR SPECTFICATION AND PERFORMANCE DATA}

\section{cocifications}

DETECTOR MODEL GC1018S

CRYOSTAT MODEL $\quad 7935 \cdot 7 \mathrm{~S}$
SERIAL NUMBER

3963627

PREAMPLEFIER MODEL 2002CSL

The purchase specification and therefore the warranted performance of this detector are as follows:

Active Volume

(Electric cooling may degrade performance by as much as 10\%.)

Resolution

Relative Efficiency $10 \%$

$1.8 \mathrm{keV}$ (FWHM) at $1.33 \mathrm{MeV}$.

- $\mathrm{keV}$ (FWTM) at $1.33 \mathrm{MeV}$

$0.70-\mathrm{keV}$ (FWHM) at $122 \mathrm{keV}$ $\mathrm{keV}$ (FWTM) at

Peak / Compton ___ $\quad$ _ Cryostat well diameter __ $\mathrm{mm}$ Cryostat well depth Cryostat description if special

Physical Characteristics

Geometry ___ Closed-end coaxial

Dianeter

$\frac{46}{28} \mathrm{~mm}$

Distance from window 5

Active Volume
Well Depth
Well Diameter
$\mathrm{mm}$

\section{Electrical Characteristics}

Depletion voltage $(+) 3000 \quad \mathrm{~V} d c$

Recommended bias voltage $s+23000 \quad \mathrm{~V} d c$

Leakage current at recommended bias $0.02 \quad$ nA

Preamplifier test point voltage at recommended voltage $-(-0.82 \quad \mathrm{~V} d \mathrm{c}$

Capacitance at recommended bias $\sim 9$ $\mathrm{pF}$

\section{Resolution and Efficiency}

With amplifier time constant of 4 microseconds

\begin{tabular}{|c|c|c|l|l|l|}
\hline Isotope & ${ }^{37} \mathrm{Co}$ & ${ }^{60} \mathrm{Co}$ & & & \\
\hline Energy (KeV) & 122 & 1332 & & & \\
\hline FWHM (KeV) & 0.69 & 1.69 & & & \\
\hline FWTM (KeV) & 1.27 & 3.16 & & & \\
\hline Peak / Compton & & $40.0: 1$ & & & \\
\hline Rel. Efficiency \% & & 10.0 & & & \\
\hline
\end{tabular}

Cool Down Time 4 hours. Cryostat Liquid Nitrogen Consumption Rate $<1.5$ Liters per Day.

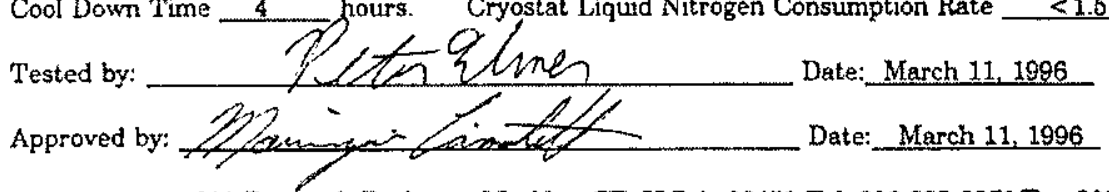

800 Research Parkway, Meriden CT. U.S.A. 06450 Tel. 203-238-2351/Fax 203-235-1347 
HNF-5148, Rev. 2

Detector assigned to GEA-A, LEGe 6.

\section{ACANBERRA DETECTOR SPECIFICATION AND PERFORMANCE DATA}

\section{Snecifications}

DETECTOR MODEL __ GC1018/S

SERIAL NUMBER 12953631

CRYOSTAT MODEL _

PREAMPLIFIER MODEL ___ 2002CSL

The purchase specification and therefore the warranted performance of this detector are as follows: (Electric cooling may degrade performance by as much as $10 \%$.
Active Volume

Active Volume

Resolution

$$
\begin{gathered}
1.8 \\
\mathrm{keV}
\end{gathered}
$$$$
<700 \quad \mathrm{keV}(\mathrm{FWHM}) \text { at } 122 \mathrm{keV}
$$
keV (FWTM) at

Peak / Compton __i Cryostat well diameter__ $\mathrm{mm} \mathrm{Cryostat} \mathrm{well} \mathrm{depth}$ Cryostat description if special

\section{Physical Characteriatics}

Geometry . Closed-end coaxial

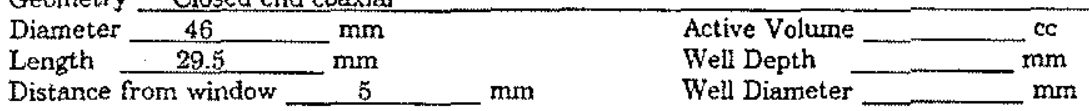

\section{Electrical Characteristics}

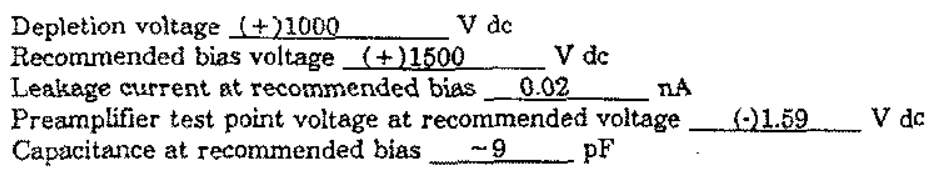

\section{Resolution and fefficiency}

With amplifier time constant of 4 microseconds

\begin{tabular}{|c|c|c|c|c|c|}
\hline Isotope & ${ }^{57} \mathrm{Co}$ & ${ }^{60} \mathrm{Co}$ & & & \\
\hline Energy (KeV) & 122 & 1332 & & & \\
\hline FWHM (KeV) & 0.70 & 1.75 & & & \\
\hline FWTM (KeV) & 1.32 & 3.26 & & & \\
\hline Peak / Compton & & $38.9: 1$ & & & \\
\hline Rel. Efriciency & & 10.1 & & & \\
\hline
\end{tabular}

Cool Down Time 4 _ hours. Cryostat Liquid Nitrogen Consumption Rate $<1.5 \quad$ Liters per Day.

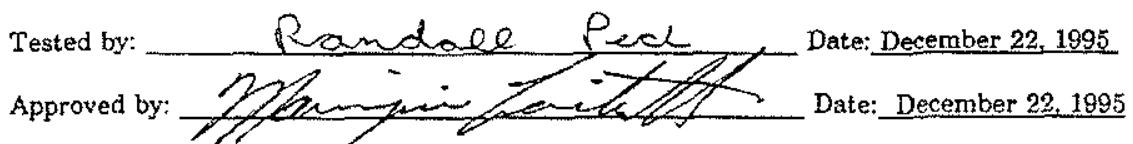

800 Research Parkway, Meriden CT. U.S.A. 06450 Tel. 203-238-2351/Fax 203-235-1347 
HNF-5148, Rev. 2

\section{A CAN BERRA DETECTOR SPECIFICATTON AND PERFORMANCE DATA}

Fnecifications

DETECTOR MODEL GC1018/S

CRYOSTAT MODEL $\quad 7935 \cdot 7 \mathrm{~S}$
SERIAL NUMBER 12953636

PREAMPLIFIER MODEL

The purchase specification and therefore the warranted performance of this detector are as follows: (Electric cooling may degrade performance by as much as $10 \%$.)

Active Volume _ $c c$ Relative Efficiency $10 \%$

Resolution $2.8 \mathrm{keV}$ (FwhM) at $1.33 \mathrm{MeV}$

- $\mathrm{keV}$ (FWTM) at $1.33 \mathrm{MeV}$

$<700 \quad \mathrm{keV}$ (FWHM) at $122 \mathrm{keV}$

Peak / Compton is Cryostat well diameter

Cryostat description if special $\mathrm{keV}$ (FW'TM) at

al

Physical Characteristics

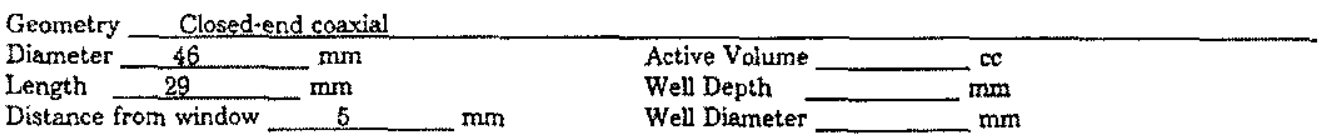

\section{Electrical Characteristies}
Depletion voltage $(+) 1200$
$\mathrm{Vdc}$
Recommended bias voltage $(+13000$
Leakage current at recommended bias $0.01 \quad n A$
Preamplifier test point voltage at recommended voltage $-(0) 2.16 \quad V \mathrm{dc}$
Capacitance at recommended bias $-8 \quad \mathrm{pF}$

\section{Resolntion and Efficiency}

With amplifier time constant of

\begin{tabular}{|c|c|c|c|c|c|}
\hline Isotope & ${ }^{37} \mathrm{Co}$ & ${ }^{60} \mathrm{Co}$ & & & \\
\hline Energy (KeV) & 122 & 1332 & & & \\
\hline FWHM (KeV) & 0.67 & 1.76 & & & \\
\hline FWTM (KeV) & 1.24 & 3.35 & & & \\
\hline Peak / Compton & & $37.2: 1$ & & & \\
\hline Rel. Efficiency \% & & 10.1 & & & \\
\hline
\end{tabular}

Cool Down Time 4 __ hours. Cryostat Liquid Nitrogen Consumption Rate $<1.5 \quad$ Liters per Day.

Tested by: Randale Pect.

Approved by:

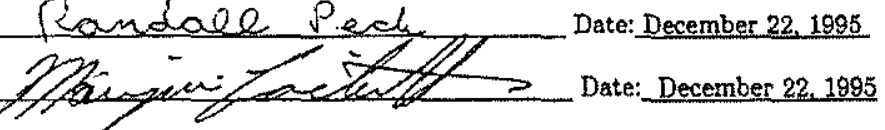

800 Research Parkway, Meriden CT. U.S.A. 06450 Tel. 203-238-2351/Fax 203-235-1347 
HNF-5148, Rev. 2

\section{A CANBERRA DETECTOR SPECIFICATION AND PERFORMANCE DATA}

\section{Enecincations}

DETECTOR MODEL GC2020

SERIAL NUMBER 12953589

CRYOSTAT MODEL

$7935-7 \mathrm{~S}$

PREAMPLIFIER MODEL 2101PCSL

The purchase specification and therefore the warranted performance of this detector are as follows: (Electric cooling may degrade performance by as much as $10 \%$.)

Active Volume

Resolution

$$
\text { cc Relative Elficiency } 20
$$

$20 \quad \mathrm{keV}$ (FWHM) at $1.33 \mathrm{MeV}$.
$\mathrm{keV}$ (FWTM) at $1.33 \mathrm{MeV}$

\&

$\mathrm{keV}$ (FWHM) at

$\mathrm{keV}$ (FWTM) at

Peak / Compton 1 Cryostat well diameter

Cryostat description if special

\section{Physical Characteristics}

Geometry Closed-end coaxial

Diameter $\mathrm{mm}$

Length $44 \mathrm{~mm}$

Distance from window $\mathrm{mm}$ Active Volume

Well Depth $\mathrm{cc}$

Well Diameter $\mathrm{mm}$ $\mathrm{mm}$ mm Cryostat well depth $\operatorname{mm}$

\section{Electrical Characteristics}
Depletion voltage $(+) 3300$ $\mathrm{V} \mathrm{dc}$
Recommended bias voltage $(+) 3500$
R de
Reset rate at recommended voltage $\frac{0.4 \quad \text { sec }}{n}$
Capacitance at recommended bias

$-19-\mathrm{pF}$

\section{Resolution and Efficiency}

With amplifier time constant of $4 \quad$ microseconds

\begin{tabular}{|c|c|c|c|c|c|}
\hline Isotope & ${ }^{57} \mathrm{Co}$ & ${ }^{60} \mathrm{Co}$ & & & \\
\hline Energy (KeV) & 122 & 1332 & & & \\
\hline FWHM (KeV) & 0.74 & 1.68 & & & \\
\hline FWTM (KeV) & 1.36 & 3.10 & & & \\
\hline Peak / Compton & & 58.0 & & & \\
\hline Rel. Efticiency \% & & 23.9 & & & \\
\hline
\end{tabular}

Cool Down Time _ـ 4 hours. Cryostat Liquid Nitrogen Consumption Rate $<1.4 \ldots$ Liters per Day.

Tested by: Approved by: Daee Date:December 22. 1995

800 Research Parkway, Meriden CT. U.S.A. 06450 Tel. 203-238-2351/Fax 203-235-1347

Dot_spec_l 10/95 $3 \mathrm{KT}$ 
HNF-5148, Rev. 2

\section{A CAN BERRA DETECTOR SPECIFICATION AND PERFORMANCE DATA}

\section{Snecifications}

DETECTOR MODEL _GC2020

SERIAL NUMBER $\quad 12953590$

CRYOSTAT MODEL $\quad 7935 \cdot 7 \mathrm{~S}$

PREAMPLIFIER MODEL 2101PCSL

The purchase specification and therefore the warranted performance of this detector are as follows:

Active Volume

(Electric cooling may degrade performance by as much as $10 \%$.)

Resolution

Relative Efficiency
$2.0 \quad \mathrm{keV}$ (FWHM) at $1.33 \mathrm{MeV}$.
$\mathrm{keV}$ (FWTM) at $1.33 \mathrm{MeV}$

$\mathrm{keV}$ (FWHM) at

$\mathrm{keV}(\mathrm{FWTM})$ at

Peak / Compton

:1 Cryostat well diameter Cryostat description if special

\section{Physical Characteristics}

Geometry Closed-end coaxial

Diameter 53

Length 4.5 .5

Distance from window 5

\begin{tabular}{l} 
Active Volume $\quad \mathrm{cc}$ \\
Well Depth $\mathrm{mm}$ \\
Well Diameter \\
\hline
\end{tabular}

\section{Electrical Characteristics}

\begin{tabular}{|c|c|}
\hline $1+$ & \\
\hline$(+) 3000$ & or \\
\hline aended bias & $\ddot{\theta}$ \\
\hline $\begin{array}{l}\text { Reset rate at recommended voltage } \\
\text { Capacitance at recommended bias }\end{array}$ & $\frac{0.6}{-19}$ \\
\hline
\end{tabular}

\section{Ressolution and Efriciency}

With amplifier time constant of 4 _ microseconds

\begin{tabular}{|c|c|c|c|c|c|}
\hline Isotope & ${ }^{57} \mathrm{Co}$ & ${ }^{60} \mathrm{Co}$ & & & \\
\hline Energy (KeV) & 122 & 1332 & & & \\
\hline FWHM (KeV) & 0.82 & 1.77 & & & \\
\hline FWTM (KeV) & 1.53 & 3.35 & & & \\
\hline Peak / Compton & & 54.9 & & & \\
\hline Rel. Efficiency \% & & 24.0 & & & \\
\hline
\end{tabular}

Cool Down Time 4 hours.

Cryostat Liquid Nitrogen Consumption Rate $<1.4$ Liters per Day.

Tested by: Ramolote Perele Date: December 22, 1995 Approved by:

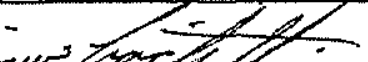
Date: December 22. 1995

800 Research Parkway, Meriden CT. U.S.A. 06450 Tel. 203-238-2351/Fax 203-235-1347 
HNF-5148, Rev. 2

\section{A CANBERRA DETECTOR SPECIFICATION AND PERFORMANCE DATA}

\section{Sinecifications}

DETECTOR MODEL _...GC2020

CRYOSTAT MODEL $\quad 7935-7 \mathrm{~S}$
SERIAL NUMBER $\quad 12953592$

PREAMPLIFIER MODEX 2101PSL

The purchase specification and therefore the warranted performance of this detector are as follows:

(Electric cooling may degrade performance by as much as 10\%.)

Active Volume
Resolution

cc

Relative Efficiency 20 $\mathrm{keV}$ (FWHM) at $\mathrm{keV}$ (FWTM) at

Peak / Compton ryostat well diameter Cryostat description if special mm Cryostat well depth $\mathrm{mm}$

\section{Physical Characteristics}

Geometry Closed-end coaxial

Diameter $53.5 \quad \mathrm{~mm}$

Length $44.5 \mathrm{~mm}$

Distance from window 5

Active Volume
Well Depth
Well Diameter
$\mathrm{mm}$

\section{Electrical Characteristics}

Depletion voltage $(+) 3800 \quad \mathrm{~V} d \mathrm{c}$ Recommended bias voltage $(+) 4000 \quad \mathrm{~V} d c$

Leakage current at recommended bias $\quad 0.01 \quad n \mathrm{~A}$

Reset rate at recommended bias voltage $0.5 \ldots \mathrm{sec}$

Capacitance at recommended bins _. $\sim 16 \quad \mathrm{pF}$

\section{Resolution and Efficiency}

With amplifier time constant of $\quad 4$ microseconds

\begin{tabular}{|c|c|c|l|l|l|}
\hline Isotope & ${ }^{57} \mathrm{Co}$ & ${ }^{60} \mathrm{Co}$ & & & \\
\hline Energy (KeV) & 122 & 1332 & & & \\
\hline FWHM (KeV) & 0.69 & 1.66 & & & \\
\hline FWTM (KeV) & 1.29 & 3.03 & & & \\
\hline Peak / Compton & & $58.2: 1$ & & & \\
\hline Rel. Efriciency \% & & 24.2 & & & \\
\hline
\end{tabular}

Cool Down Time 4 hours. Cryostat Liquid Nitrogen Consumption Rate $\leq 1,4 \quad$ Liters per Day.

Tested by:__Late Datember 22, 1995

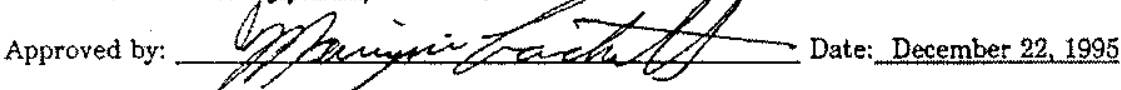

800 Research Farkway, Meriden CT. U.SA. 06450 Tel. 203-238-2351/Fax 203-235-1347

Det_Spec_1 10/95 JMT 
HNF-5148, Rev. 2

\section{A CAN SERPA DETECTOR SPECIFICATION AND PERFORMANCE DATA}

\section{Srecifications}

DETECTOR MODEL GC2020

CRYOSTAT MODEL $\quad 7935 \cdot 7 \mathrm{~S}$
SERIAL NUMBER 12953596

PREAMPLIFIER MODEL $2101 P$

The purchase specification and therefore the warranted performance of this detector are as follows:

(Electric cooling may degrade performance by as much as $10 \%$ )

Active Volume

Resolution

Relative Efficiency 20

q

2.0
$\mathrm{keV}($ FWHM) at $1.33 \mathrm{MeV}$
$\mathrm{keV}$ (FWTM) at $1.33 \mathrm{MeV}$

$\mathrm{keV}$ (FWHM) at $\mathrm{keV}$ (FWTM) at

Peak / Compton $46-1$ Cryostat well diameter __ $\mathrm{mm}$ Cryostat well depth $\mathrm{mm}$ Cryostat description if special

\section{Physical Characteristics}

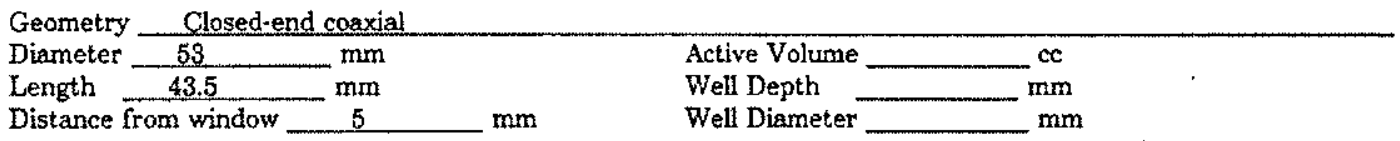

\section{Glectrical Characteristics}

Depletion voltage $\frac{(t) 1500}{\text { Recommended bias voltage }(+) 2500} \mathrm{~V} \mathrm{dc}$
Leakage current at recommended bias $\mathrm{Ad}$
Reset rate at recommended voltage $\frac{0.6}{-18} \mathrm{nA}$
Capacitance at recommended bias $\mathrm{pF}$

Resolution and Ffficiency

With amplifier time constant of

\begin{tabular}{|c|c|c|c|c|c|}
\hline Isotope & ${ }^{57} \mathrm{Co}$ & ${ }^{60} \mathrm{Co}$ & & & \\
\hline Energy (KeV) & 122 & 1332 & & & \\
\hline FWHM (KeV) & 0.73 & 1.72 & & & \\
\hline FWTM (KeV) & 1.33 & 3.18 & & & \\
\hline Peak/ Compton & & 55.6 & & & \\
\hline Rel. Efriciency \% & & 22.3 & & & \\
\hline
\end{tabular}

Cool Down Time hours.

Cryostat Liquid Nitrogen Consumption Rate $<1.4$ Liters per Day.

Tested by: Oamalael

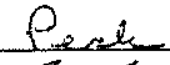
Date: December 22, 1995

Approved by:

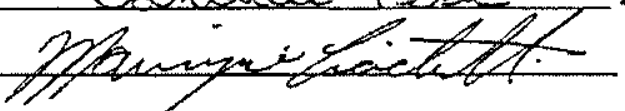

Date:_December 22, 1995

800 Research Parkway, Meriden CT. U.S.A. 06450 Tel. 203-238-2351/Fax 203-235-1347

Det_spec_1 $10 / 95 \mathrm{JMT}$ 
HNF-5148, Rev. 2

\section{A CANBERRA DETECTOR SPECIFICATION AND PERFORMANCE DATA}

$r$ scifications

DETECTOR MODEL GC2020

SFRIAL NUMABER 3963597

CRYOSTAT MODEL $7935 \cdot 7 \mathrm{~S}$

PREAMPLIFIER MODEL 2101PCSL

The purchase specification and therefore the warranted performance of this detector are as follows:

Active Volume

(Electric cooling may degrade performance by as much as $10 \%$.)

Resolution

Relative Efficiency 20

$2.0 \mathrm{keV}(\mathrm{FWHM})$ at $1.33 \mathrm{MeV}$

$\mathrm{keV}$ (FWTM) at $1.33 \mathrm{MeV}$

$\mathrm{keV}$ (FWHM) at

$\mathrm{keV}$ (FWTM) at

Peak / Compton

:1 Cryostat well diameter

Cryostat description if special Big Mac mm Cryostat well depth $m m$

\section{Physical Characteristics}

Geometry

Diameter

Closed.end coaxial

Length $\frac{4}{42} \mathrm{~mm}$

Distance from window 5

$\begin{array}{ll} & \text { Active Volume } \\ \mathrm{mm} & \text { Well Depth }\end{array}$

Well Diameter cc

$\mathrm{mm}$

ctrical Characteristics

Depletion voltage $(t) 3500 \quad \mathrm{~V} d c$

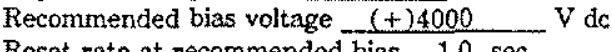

Reset rate at recommended bias $1.0 \mathrm{sec}$

Preamplifier test point voltage at recommended voltage

Capacitance at recommended bias -18 $\mathrm{pF}$ $V d c$

\section{Resolution and Efficiency}

With amplifier time constant of ___ m___ microseconds

\begin{tabular}{|c|c|c|c|c|c|}
\hline Isotope & ${ }^{57} \mathrm{Co}$ & ${ }^{60} \mathrm{Co}$ & & & \\
\hline Energy (KeV) & 122 & 1332 & & & \\
\hline FWHM (KeV) & 0.79 & 1.75 & & & \\
\hline FWTM (KeV) & 1.46 & 3.24 & & & \\
\hline Peak / Compton & & $53.5: 1$ & & & \\
\hline Rel. Efriency \% & & 23.5 & & & \\
\hline
\end{tabular}

Cool Down Time 4 hours. Cryostat Liquid Nitrogen Consumption Rate $<1.4 \quad$ Liters per Day.

rested by: _. Date: March 11.1996

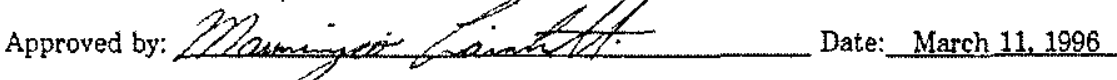

800 Research Parkway, Meriden CT. U.SA. 06450 Tel 203-238-2351/Fax 203-235-1347 
HNF-5148, Rev. 2

\section{A CANBERRA DETECTOR SPECTFICATION AND PERFORMANCE DATA}

$r$ ?cifications

DETECTOR MODEL _ GC2020

SERIAL NUMBER

3963606

CRYOSTAT MODEL $\quad 7935-78$

PREAMPLIFIER MODEL 2101P

The purchase specification and therefore the warranted performance of this detector are as follows:

Active Volume

(Electric cooling may degrade performance by as much as 10\%.)

Resolution

Relative Efficiency 20

$\%$

2.0

$\mathrm{keV}$ (FWHM) at

$\mathrm{keV}$ (FWTM) at

Peak / Compton :1 Cryostat well diameter

Cryostat description if special

Physical Characteristics

Geometry Closed.end coaxial

Diameter $56 \quad \mathrm{~mm}$

Length $\frac{43.5}{\mathrm{~mm}}$

Distance from window

5 $\mathrm{mm}$

Active Volume
Well Depth $\mathrm{cc}$
Well Diameter

\section{Blectrical Characteristics}

Depletion voltage $(+) 1300 \quad V$ dc Recommended bias voltage $(+) 2500$

Leakage current at recommended bias _.. $n$ n

Preamplifier test point voltage at recommended voltage

Capacitance at recommended bias $\sim 27 \quad \mathrm{pF}$

Reset Rate $0.2 \mathrm{sec}$

Resolution and Bfficiency

With amplifier time constant of 4 microseconds

\begin{tabular}{|c|c|c|c|c|c|}
\hline Isotope & ${ }^{57} \mathrm{Co}$ & ${ }^{60} \mathrm{Co}$ & & & \\
\hline Energy (KeV) & 122 & 1332 & & & \\
\hline FWHM (KeV) & 0.76 & 1.90 & & & \\
\hline FWTM (KeV) & 1.42 & 3.65 & & & \\
\hline Peak / Compton & & $51.4: 1$ & & & \\
\hline Rel. Efficiency \% & & 25.5 & & & \\
\hline
\end{tabular}

Cool Down Time 4 hours. Cryostat Liquid Nitrogen Consumption Rate $<1.5$ Liters per Day.

Tested by: Masle 30 Date March 11, 1996

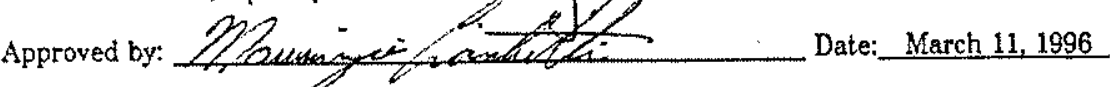

800 Research Parkway, Meriden CT. U.S.A 06450 Tel 203-238-2351/Fax 203-235-1347

Det_spoc_2 20/95 JK: 
HNF-5148, Rev. 2

A CAN BERRA DETECTOR SPECIFICATION AND PERFORMANCE DATA

$r$ scifications

DETECTOR MODEL _ GC2020

SERIAL NUMBER _ $\quad 3963611$

CRXOSTAT MODEL $\quad 7935-7 \mathrm{~S}$

PREAMPLIFTER MODEL 2101PCSL

The purchase specification and therefore the warranted performance of this detector are as follows:

Active Volume

(Electric cooling may degrade performance by as much as $10 \%$.)

Resolution

cc

Relative Efficiency

20

$\%$

$\frac{2.0}{\mathrm{keV}}$ (FWHM) at $1.33 \mathrm{MeV}$.

$\mathrm{KeV}$ (FWHM) at

$\mathrm{keV}$ (FWTM) at

Peak / Compton ___ :1 Cryostat well diameter

Cryostat description if special

Physical Characteristics

Geometry _._. Closed-end coaxial

Diameter $\frac{55}{45} \mathrm{~mm}$

Length $\frac{43.5}{-1.5 m}$

Distance from window 5

m

$\mathrm{mm}$

Active Volume
Well Depth
Well Diameter
$\mathrm{mm}$
$\mathrm{mm}$

\section{Electrical Characteristics}

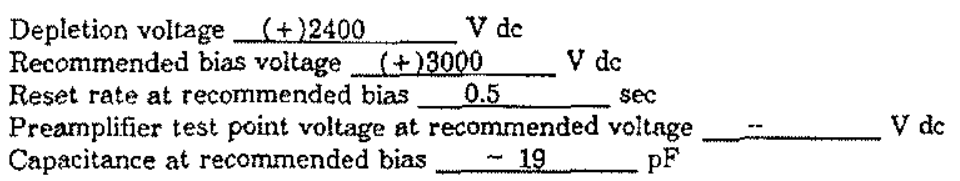

Resolution and Efficiency

With amplifier time constant of ___ microseconds

\begin{tabular}{|c|c|c|c|c|c|}
\hline Isotope & ${ }^{57} \mathrm{Co}$ & ${ }^{60} \mathrm{Co}$ & & & \\
\hline Energy (KeV) & 122 & 1332 & & & \\
\hline FWHM (KeV) & 0.76 & 1.83 & & & \\
\hline FWTM (KeV) & 1.41 & 3.43 & & & \\
\hline Peak / Compton & & 52.1 & & & \\
\hline Rel. Efriciency 5 & & 25.2 & & & \\
\hline
\end{tabular}

Cool Down Time $\quad 4 \quad$ hours. Cryostat Liquid Nitrogen Consumption Rate __1.4 Liters per Day.

Tested by:_Later_March 11. 1996

Approved by:

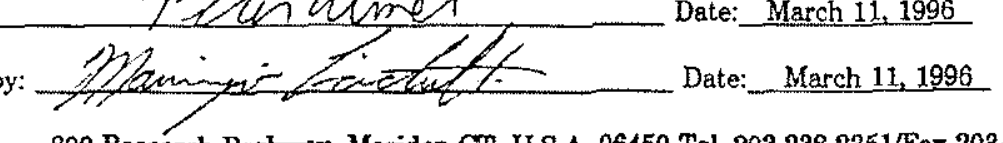

800 Research Parkway, Meriden CT. U.S.A. 06450 Tel. 203-238-2351/Fax 203-235-1347

Det_spec_3 10/95 JMT 
HNF-5148, Rev. 2

\section{A Can BERra Detector specticatton and PERFormance data}

Sngcifications

DETECTOR MODEL

$\operatorname{GC2020}$

SERIAL NUMBER

3963617

CRYOSTAT MODEL

$7935-7 \mathrm{~S}$

PREAMPLIFTER MODEL

2101PCSL

The purchase specification and therefore the warranted performance of this detector are as follows: (Electric cooling may degrade performance by as much as 10\%.)

Active Volume

Resolution

$$
\text { cc Relative Efficiency 20 } \%
$$

$2.0 \mathrm{keV}$ (FWHM) at $1,33 \mathrm{MeV}$

$\mathrm{keV}$ (FWTM) at $1.33 \mathrm{MeV}$

$\mathrm{keV}$ (FWHM) at

$\mathrm{keV}$ (FWTM) at

Peak / Compton $: 1$ Cryostat well diameter $\mathrm{mm}$ Cryostat well depth $\mathrm{mm}$ Cryostat description if special

Physical Characteristics

Geometry Closed-end coaxial

Diameter $\quad 53.5 \mathrm{~mm}$

Length $\frac{43}{4 m}$

Distance from window 5

mam

Active Volume __ $\mathrm{mm}$
Well Depth
Well Diameter
$\mathrm{mm}$

\section{Electrical Characteristics}

Depletion voltage $(+) 5000$ Recommended bias voltage $(+) 5000$

Reset rate at recommended bias $0.4 \quad \mathrm{sec}$

Preamplifier test point voltage at recommended voltage

Capacitance at recommended bias $-19 \quad \mathrm{pF}$ $\mathrm{V} \mathrm{d} c$

\section{Resolution and efficiency}

With amplifier time constant of 4 microseconds

\begin{tabular}{|c|c|c|c|c|c|}
\hline Isotope & ${ }^{37} \mathrm{Co}$ & ${ }^{60} \mathrm{Co}$ & & & \\
\hline Energy (KeV) & 122 & 1332 & & & \\
\hline FWHM (KeV) & 0.84 & 1.73 & & & \\
\hline FWTM (KeV) & 1.57 & 8.17 & & & \\
\hline Peak / Compton & & $56.1: 1$ & & & \\
\hline Rel. Efriciency \% & & 23.9 & & & \\
\hline
\end{tabular}

Cool Down Time $4 \quad$ hours. Cryostat Liquid Nitrogen Consumption Rate $\leq 1.4 \quad$ Liters per Day.

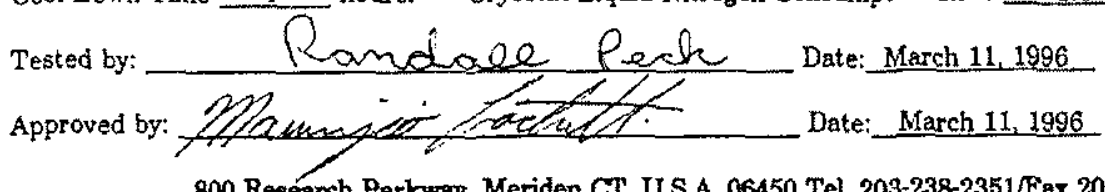

800 Research Parkway, Meriden CT. U.S.A. O6450 Tel. 203-238-2351/Fax 203-235-1347 
HNF-5148, Rev. 2

\section{APPENDIX D}

\section{Energy and FWHM}

Data and Curves 
HNF-5148, Rev. 2

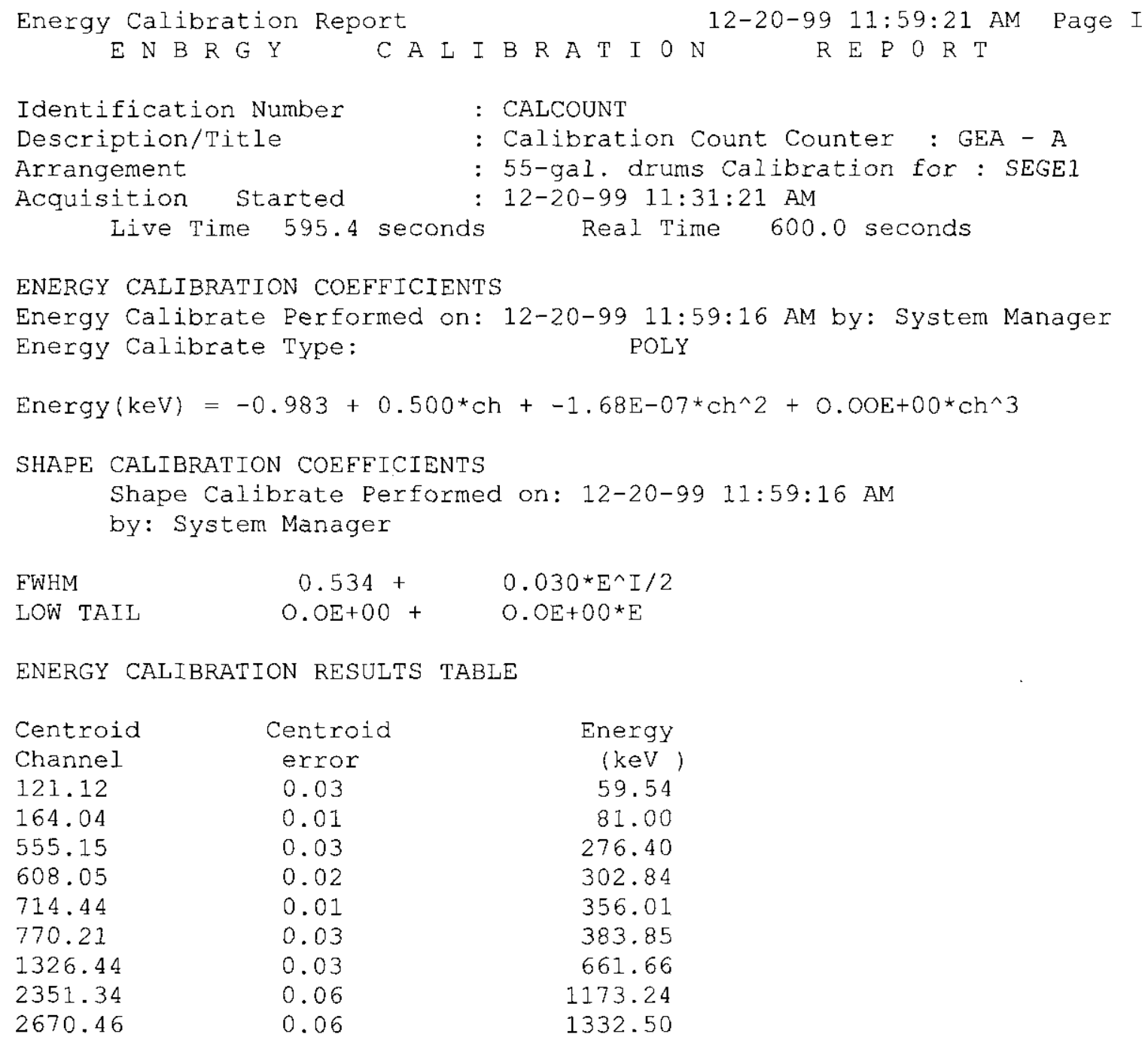


HNF-5148, Rev. 2

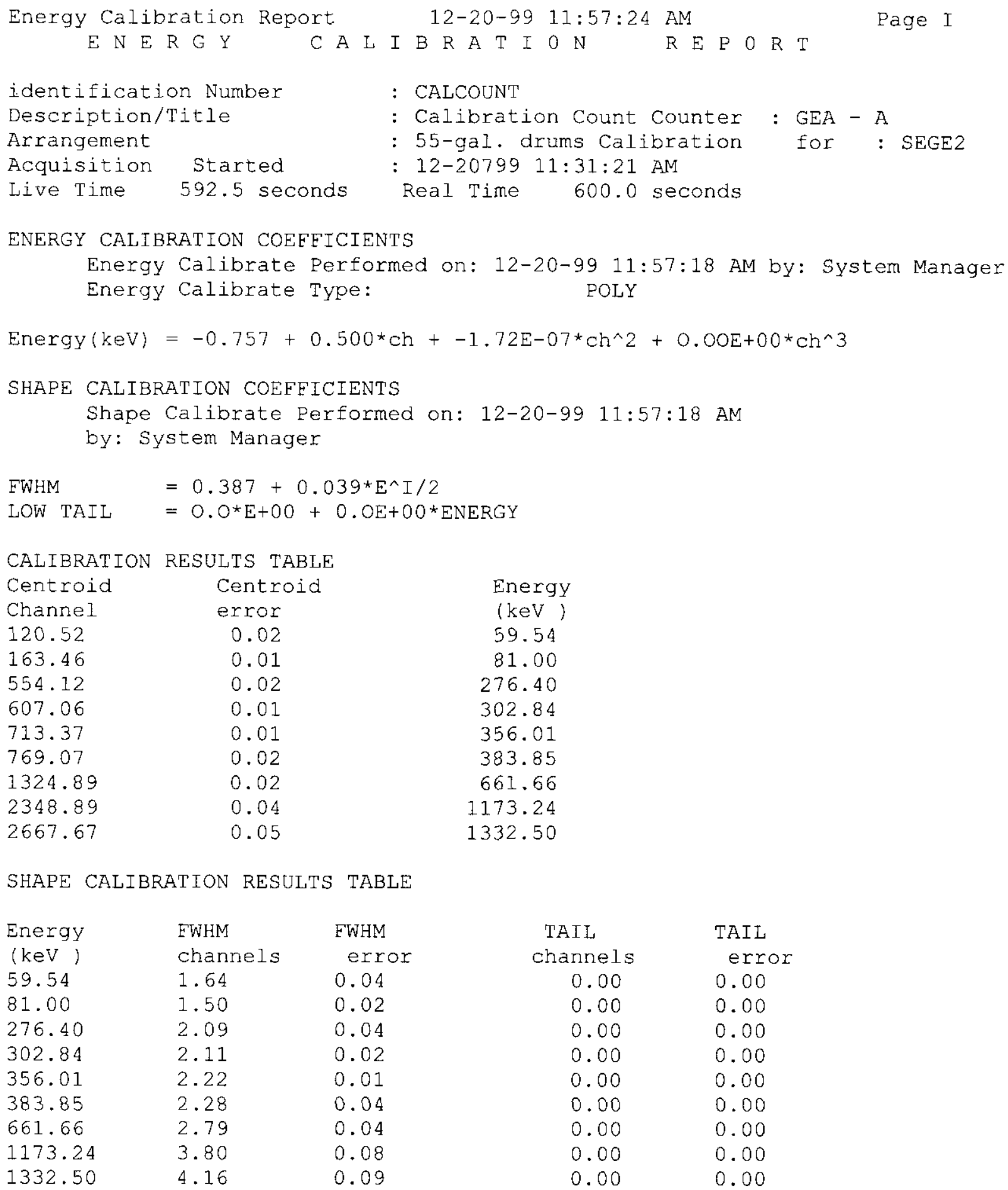


HNF-5148, Rev. 2

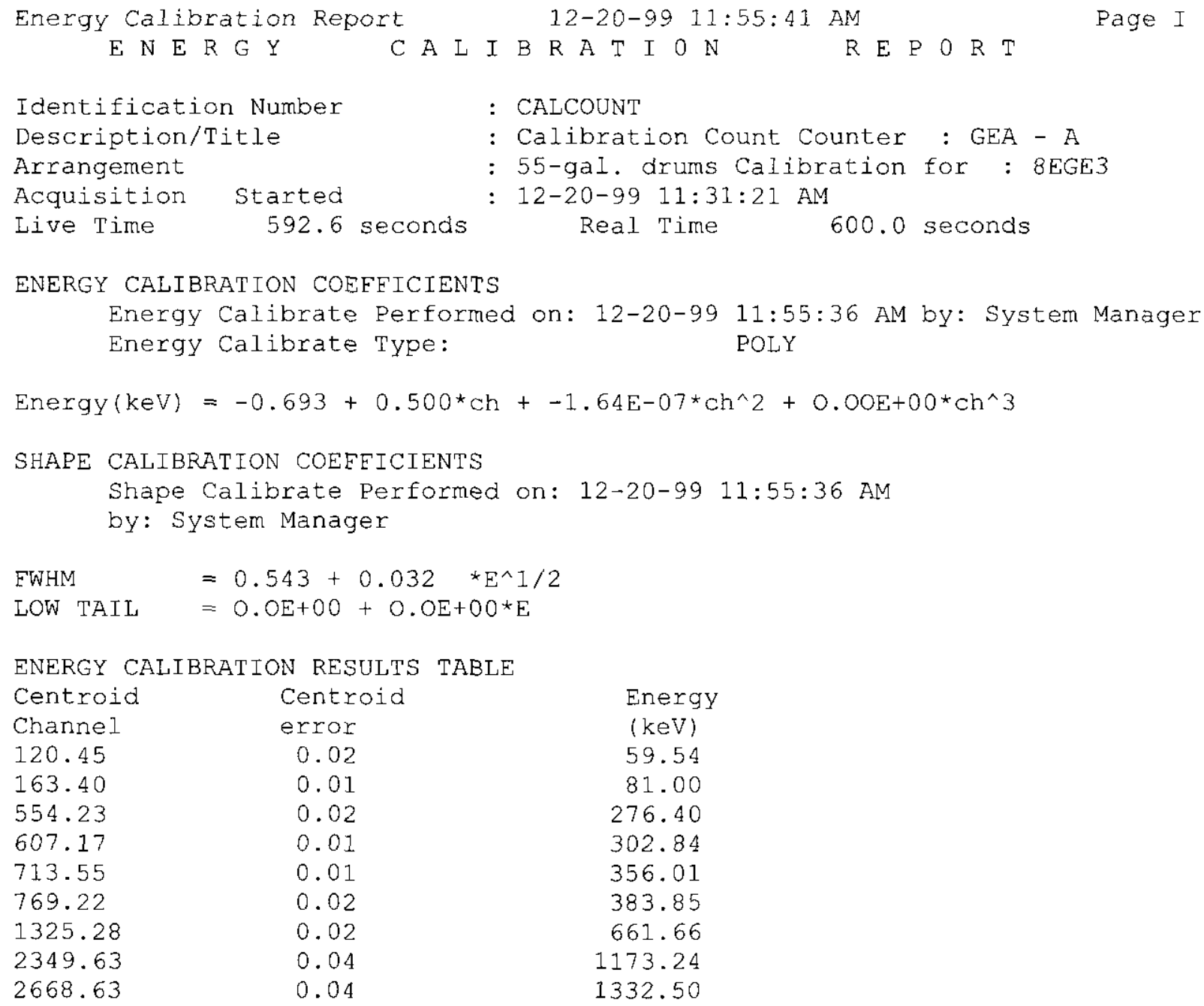

$\begin{array}{lcccc}\begin{array}{c}\text { Energy } \\ (\mathrm{keV})\end{array} & \begin{array}{c}\text { EWHM } \\ \text { channels }\end{array} & \begin{array}{c}\text { EWHM } \\ \text { error }\end{array} & \begin{array}{c}\text { TAIL } \\ \text { channels }\end{array} & \begin{array}{c}\text { TAIL } \\ \text { error }\end{array} \\ 59.54 & 1.72 & 0.04 & 0.00 & 0.00 \\ 81.00 & 1.68 & 0.02 & 0.00 & 0.00 \\ 276.40 & 2.12 & 0.04 & 0.00 & 0.00 \\ 302.84 & 2.18 & 0.02 & 0.00 & 0.00 \\ 356.01 & 2.25 & 0.01 & 0.00 & 0.00 \\ 383.85 & 2.20 & 0.04 & 0.00 & 0.00 \\ 661.66 & 2.76 & 0.04 & 0.00 & 0.00 \\ 1173.24 & 3.48 & 0.07 & 0.00 & 0.00 \\ 1332.50 & 3.73 & 0.08 & 0.00 & 0.00\end{array}$


HNF-5148, Rev. 2

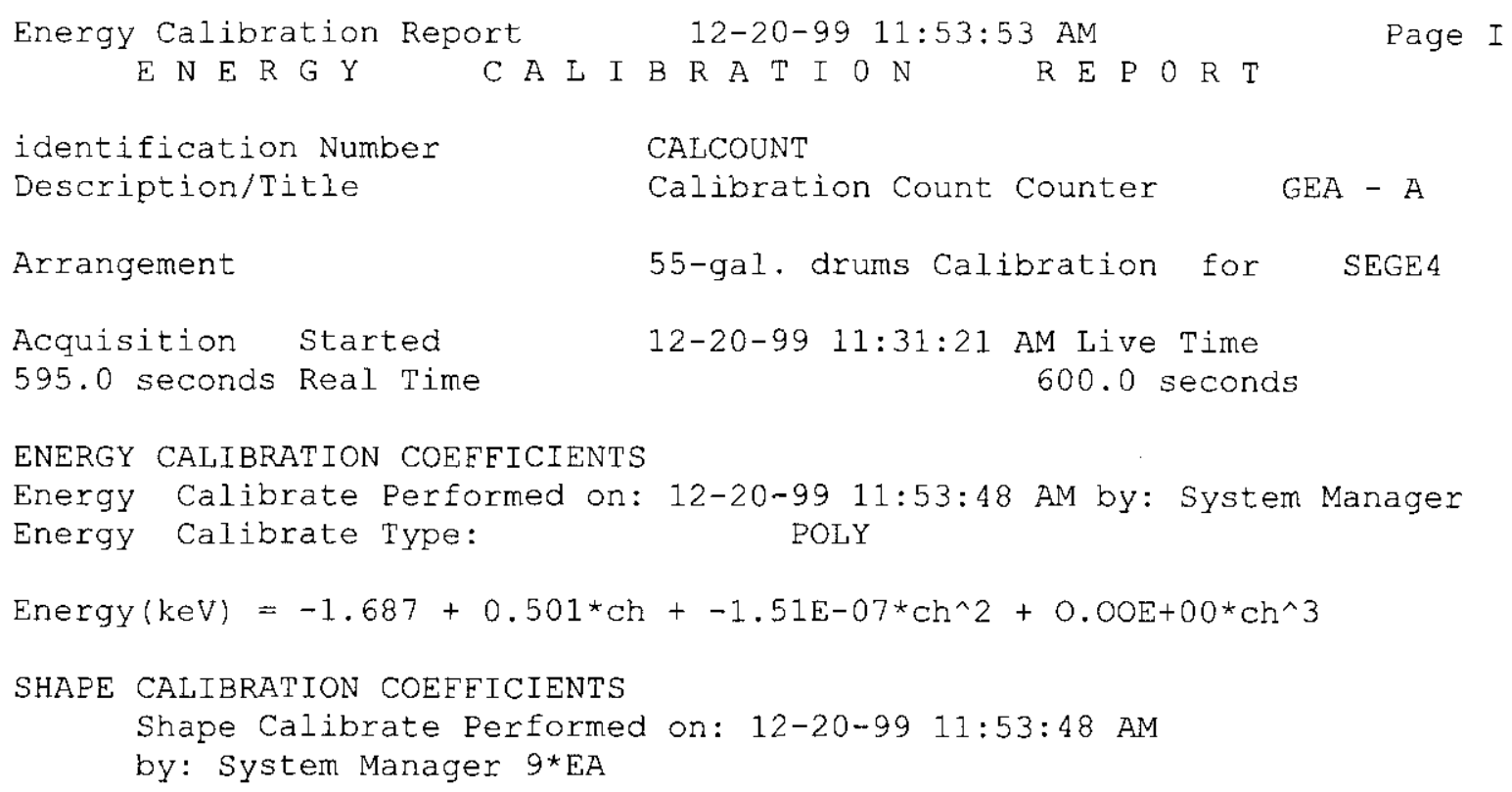

2667.71

SHAPE CALIBRATION RESULTS

TABLE

$\begin{array}{lccrl}\begin{array}{c}\text { Energy } \\ (\mathrm{keV})\end{array} & \begin{array}{c}\text { FWHM } \\ \text { channels }\end{array} & \begin{array}{c}\text { FWHM } \\ \text { error }\end{array} & \begin{array}{c}\text { TAIL } \\ \text { channels }\end{array} & \begin{array}{l}\text { TAIL } \\ \text { error }\end{array} \\ 59.54 & 1.61 & 0.05 & 0.00 & 0.00 \\ 81.00 & 1.59 & 0.02 & 1.00 & 0.00 \\ 276.40 & 2.00 & 0.06 & 0.00 & 0.00 \\ 302.84 & 2.05 & 0.03 & 0.00 & 0.00 \\ 356.01 & 2.13 & 0.02 & 0.00 & 0.00 \\ 383.85 & 2.16 & 0.06 & 0.00 & 0.00 \\ 661.66 & 2.52 & 0.05 & 0.00 & 0.00 \\ 1173.24 & 3.21 & 0.09 & 0.00 & 0.00 \\ 1332.50 & 3.33 & 0.09 & 0.00 & 0.00\end{array}$




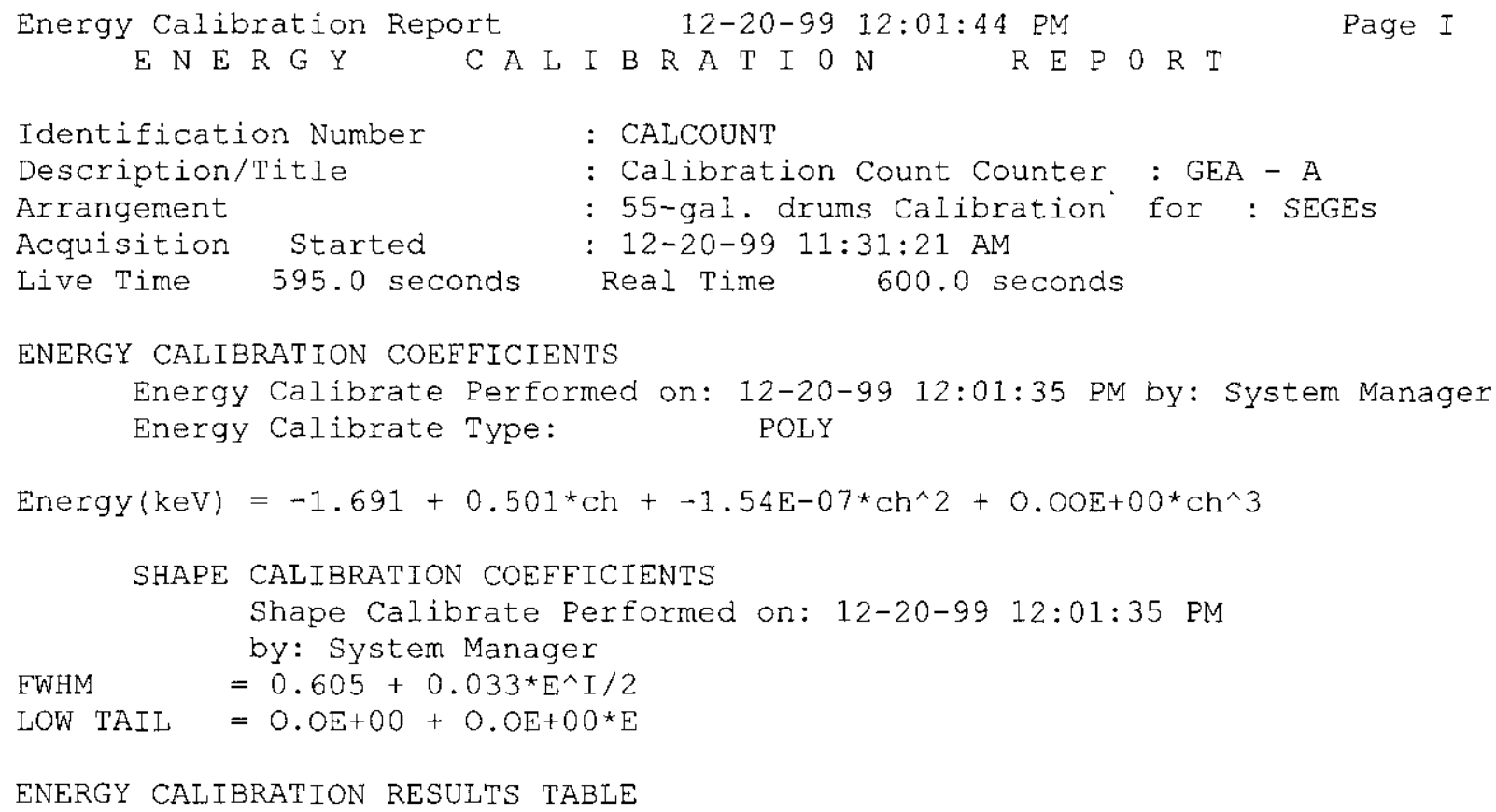

$\begin{array}{lcr}\begin{array}{l}\text { Centroid } \\ \text { Channel }\end{array} & \begin{array}{c}\text { Centroid } \\ \text { error }\end{array} & \begin{array}{c}\text { Energy } \\ (\mathrm{keV})\end{array} \\ 122.31 & 0.01 & 59.54 \\ 165.22 & 0.01 & 81.00 \\ 555.64 & 0.01 & 276.40 \\ 608.51 & 0.01 & 302.84 \\ 714.76 & 0.00 & 356.01 \\ 770.38 & 0.01 & 383.85 \\ 1325.82 & 0.01 & 661.66 \\ 2348.98 & 0.02 & 1173.24 \\ 2667.61 & 0.02 & 1332.50\end{array}$

SHAPE CALII3RATION RESULTS TABLE

$\begin{array}{lcccc}\begin{array}{c}\text { Energy } \\ (\mathrm{keV})\end{array} & \begin{array}{c}\text { FWHM } \\ \text { channels }\end{array} & \begin{array}{c}\text { EWHM } \\ \text { error }\end{array} & \begin{array}{c}\text { TAIL } \\ \text { channels }\end{array} & \begin{array}{c}\text { TAIL } \\ \text { error }\end{array} \\ 59.54 & 1.86 & 0.03 & 0.00 & 0.00 \\ 81.00 & 1.80 & 0.01 & 0.00 & 0.00 \\ 276.40 & 2.35 & 0.03 & 0.00 & 0.00 \\ 302.84 & 2.36 & 0.02 & 0.00 & 0.00 \\ 356.01 & 2.41 & 0.01 & 0.00 & 0.00 \\ 38385 & 2.40 & 0.03 & 0.00 & 0.00 \\ 661.66 & 2.85 & 0.02 & 0.00 & 0.00 \\ 1173.24 & 3.63 & 0.04 & 0.00 & 0.00 \\ 1332.50 & 3.81 & 0.04 & 0.00 & 0.00\end{array}$


HNF-5148, Rev. 2

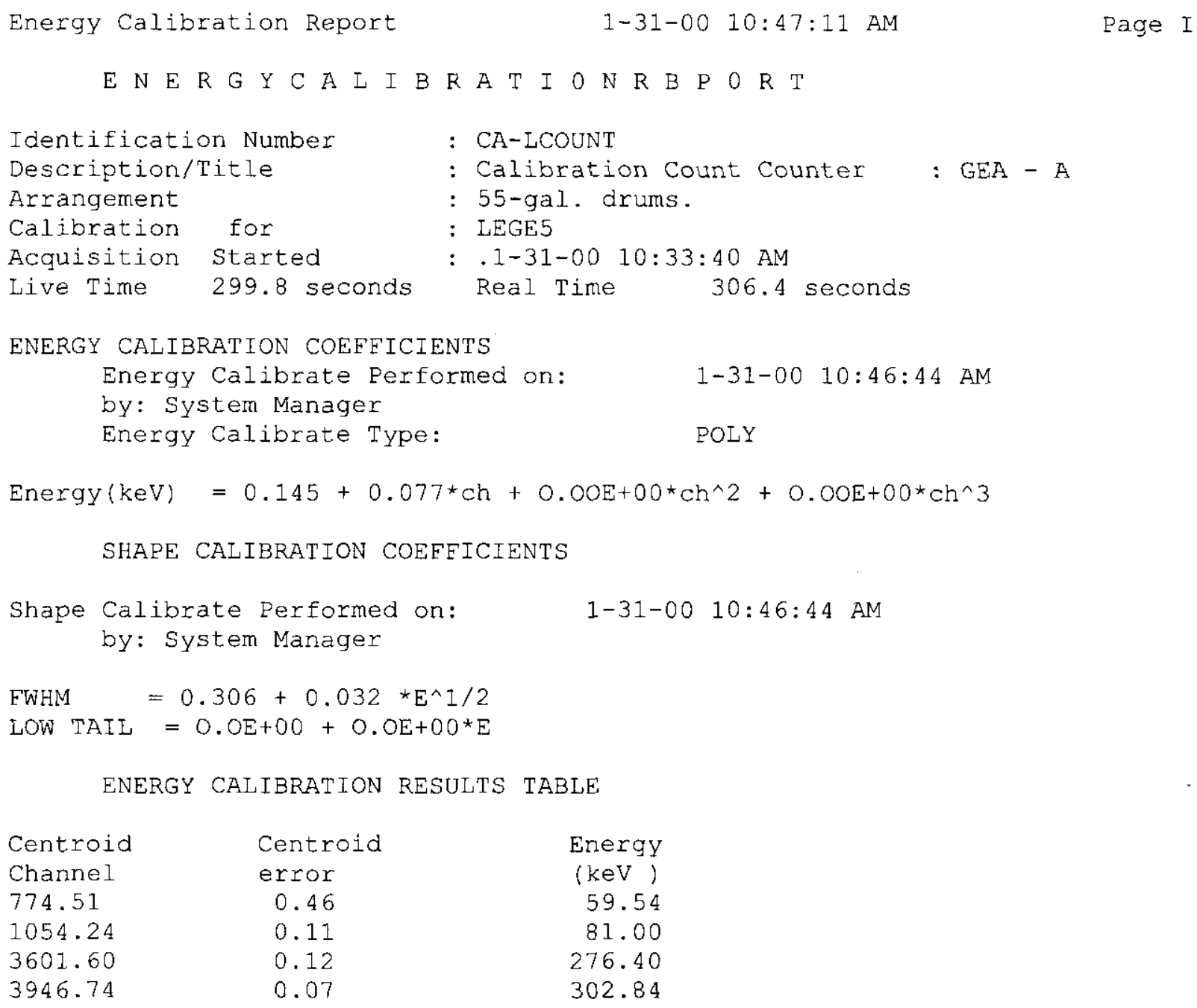

Centroid
error
0.46
0.11
0.12
0.07

Energy (keV) 59.54 81.00 276.40 302.84

SHAPE CALIBRATION RESULTS TABLE

$\begin{array}{ccccc}\begin{array}{c}\text { Energy } \\ (\mathrm{keV})\end{array} & \begin{array}{c}\text { FWHM } \\ \text { channels }\end{array} & \begin{array}{c}\text { FWHM } \\ \text { error }\end{array} & \begin{array}{c}\text { TAIL } \\ \text { channels }\end{array} & \begin{array}{c}\text { TAIL } \\ \text { error }\end{array} \\ 59.54 & 5.61 & 1.05 & 0.00 & 0.00 \\ 81.00 & 7.80 & 0.23 & 0.00 & 0.00 \\ 276.40 & 11.38 & 0.25 & 0.00 & 0.00 \\ 302.84 & 11.13 & 0.14 & 0.00 & 0.00\end{array}$


HNF-5148, Rev. 2

Energy Calibration Report

E N E R G Y C A I I B R A T I O

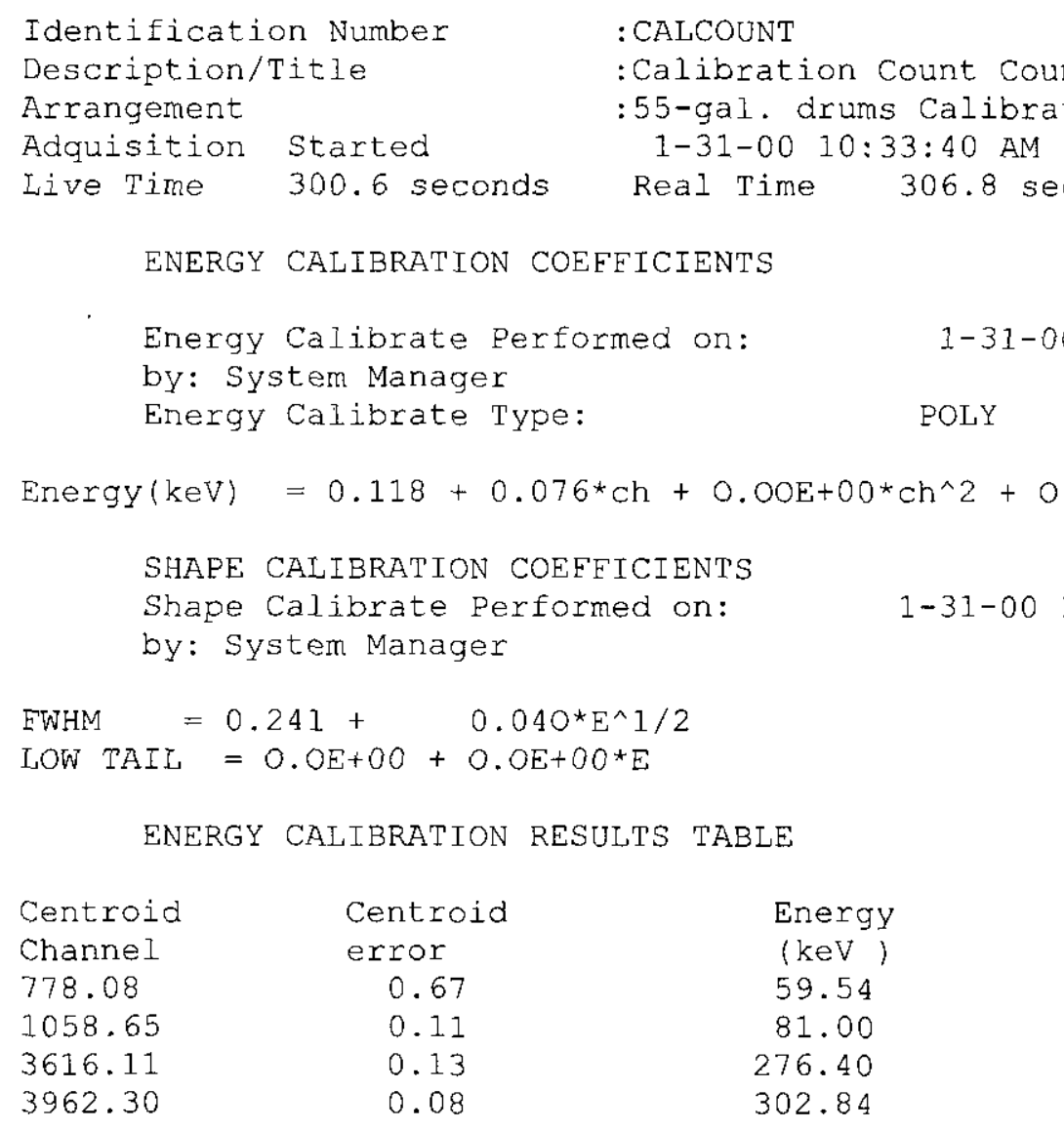

Centroid
error
0.67
0.11
0.13
0.08
302.84

SHAPE CALIBRATION RESULTS TABLE

$\begin{array}{ccccc}\begin{array}{c}\text { Energy } \\ (\mathrm{keV})\end{array} & \begin{array}{c}\text { EWHM } \\ \text { channels }\end{array} & \begin{array}{c}\text { FWHM } \\ \text { error }\end{array} & \begin{array}{c}\text { TAIL } \\ \text { channels }\end{array} & \begin{array}{l}\text { TAIL } \\ \text { error }\end{array} \\ 59.54 & 4.90 & 1.38 & 0.00 & 0.00 \\ 81.00 & 8.00 & 0.24 & 0.00 & 0.00 \\ 276.40 & 11.72 & 0.25 & 0.00 & 0.00 \\ 302.84 & 12.40 & 0.15 & 0.00 & 0.00\end{array}$


HNF-5148, Rev. 2

\section{APPENDIX E}

SEGe Efficiency

Data and Curves

E-1 
HNF-5148, Rev. 2

Foam Drum, density $=0.01346 \mathrm{gms} / \mathrm{cc}$, No Shield (collimator). Spectrum Seq \# 3988

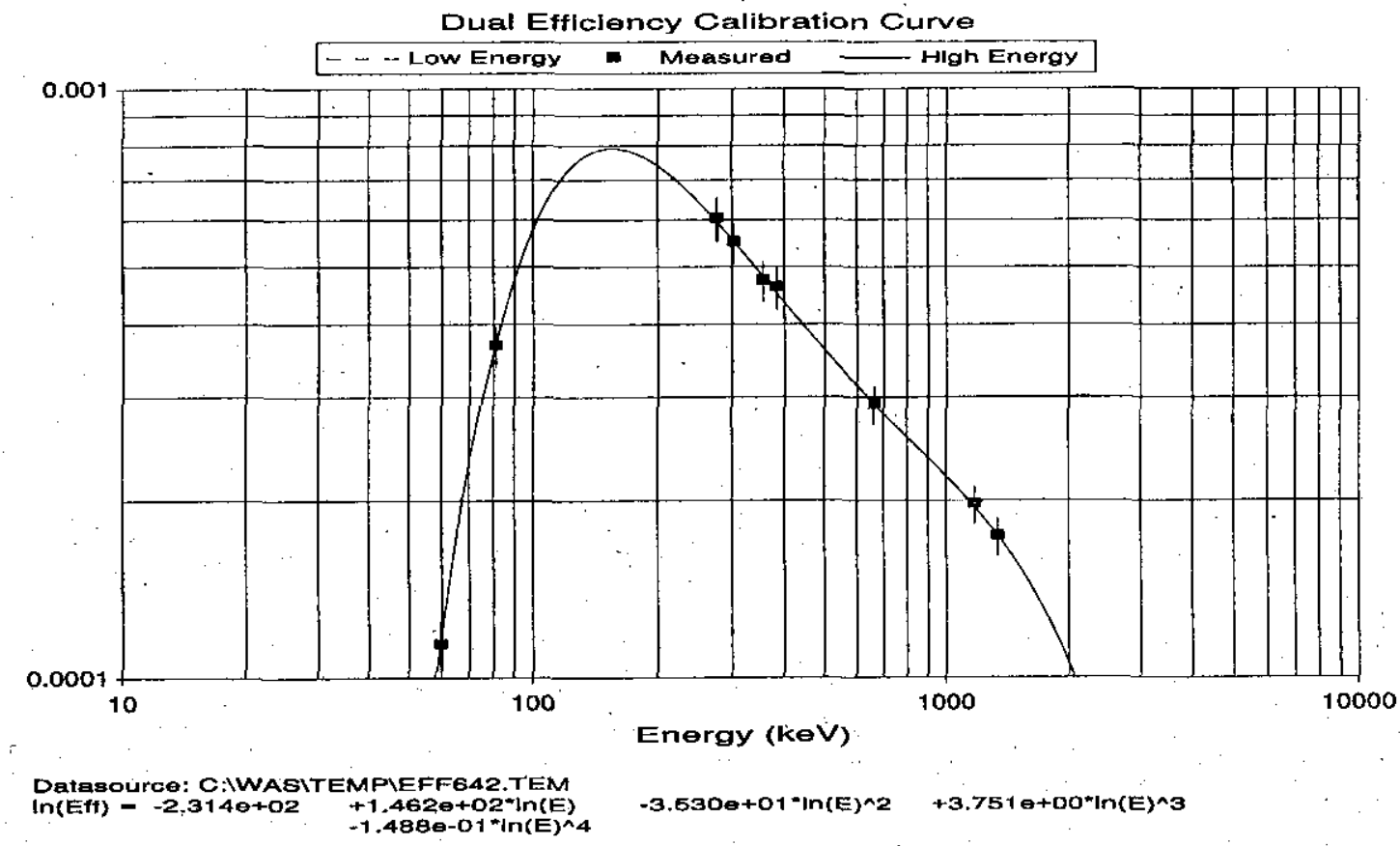

Seg 2, SEGe 4, Drum position 2.

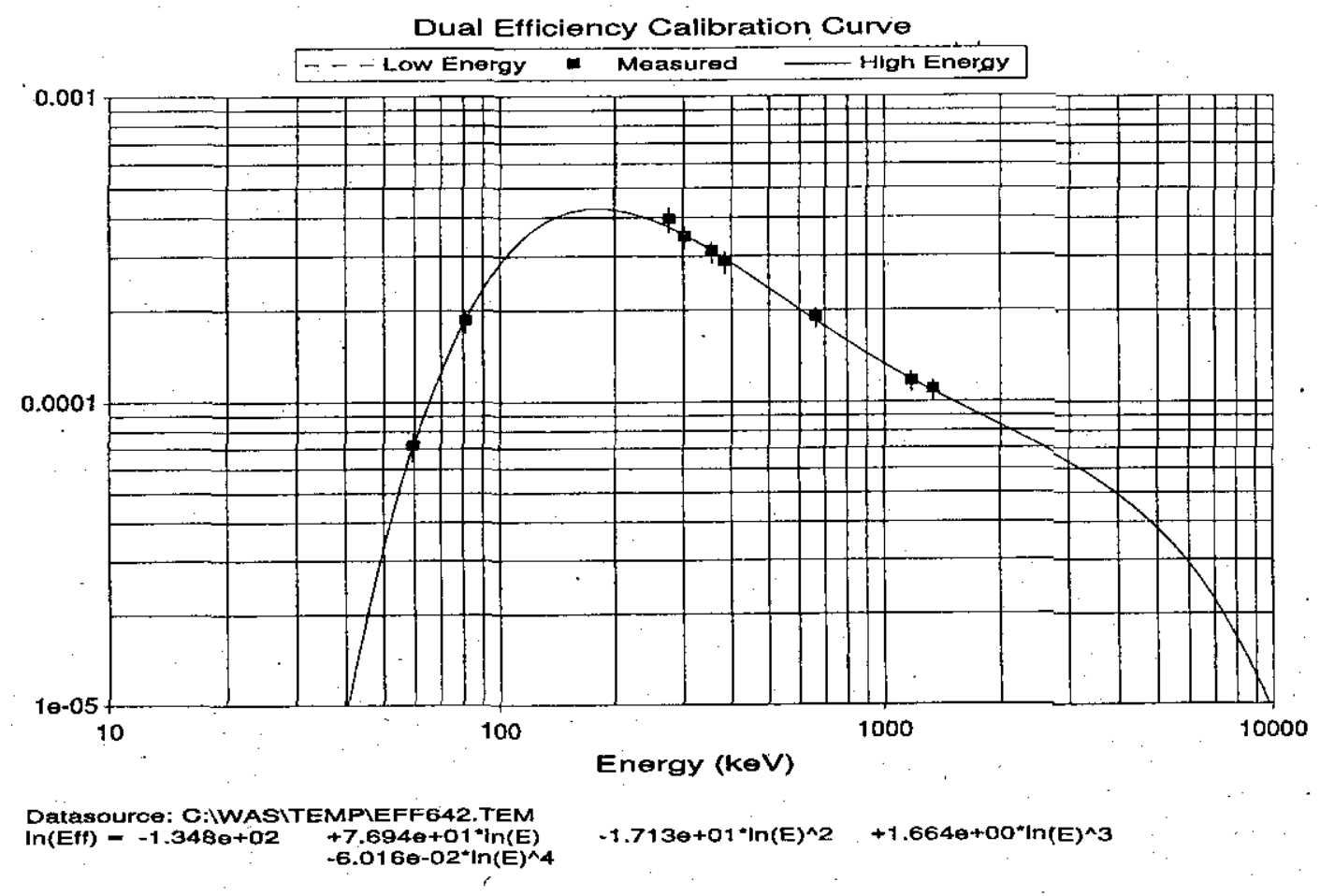

Seg 3, SEGe 4, Drum position 3. 
HNF-5148, Rev. 2

Foam Drum, density $=0.01346 \mathrm{gms} / \mathrm{cc}$, No Shield (collimator). Spectrum Seq \#3988

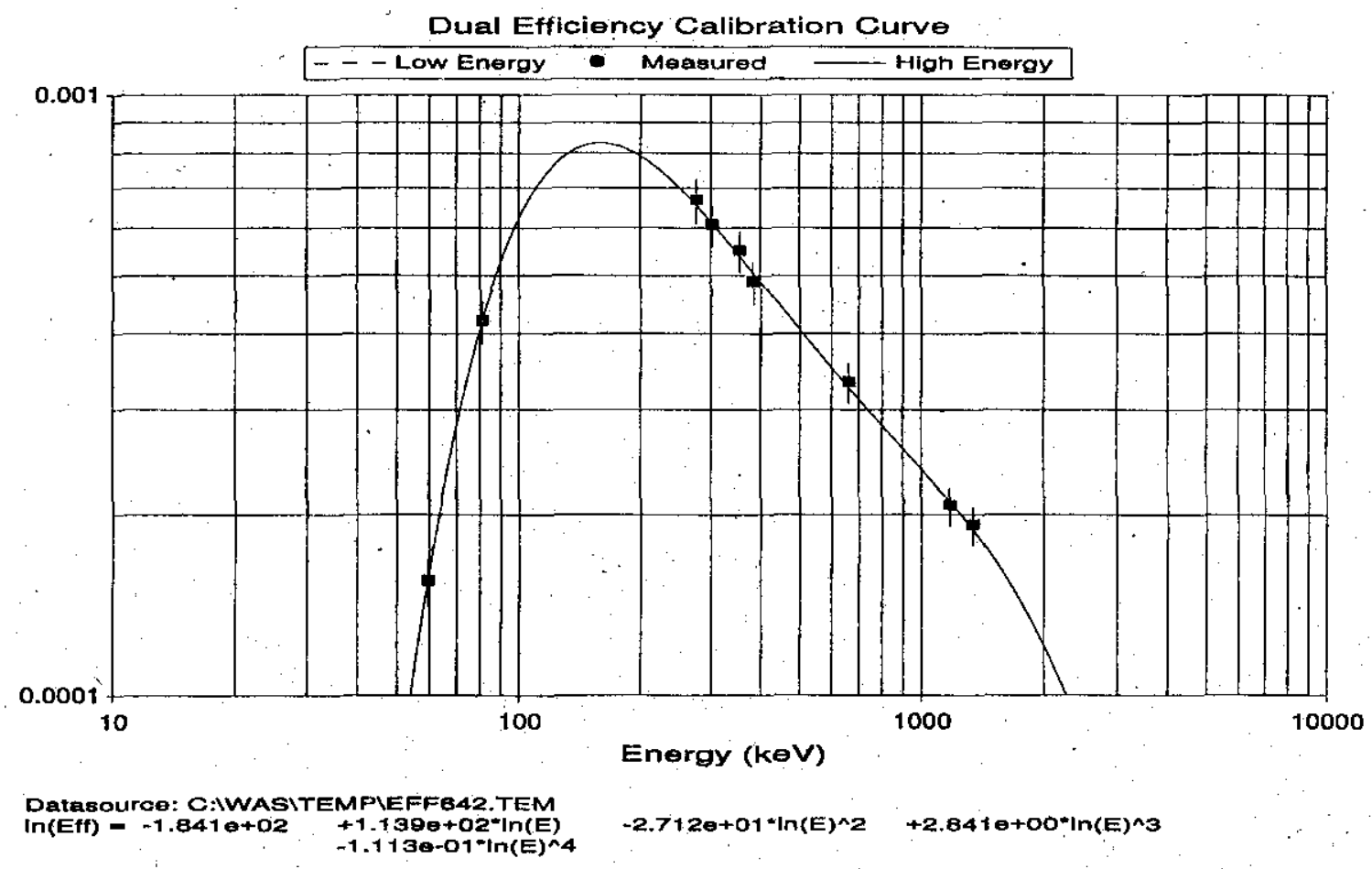

Seg 4, SEGe 3, Drum position 1.

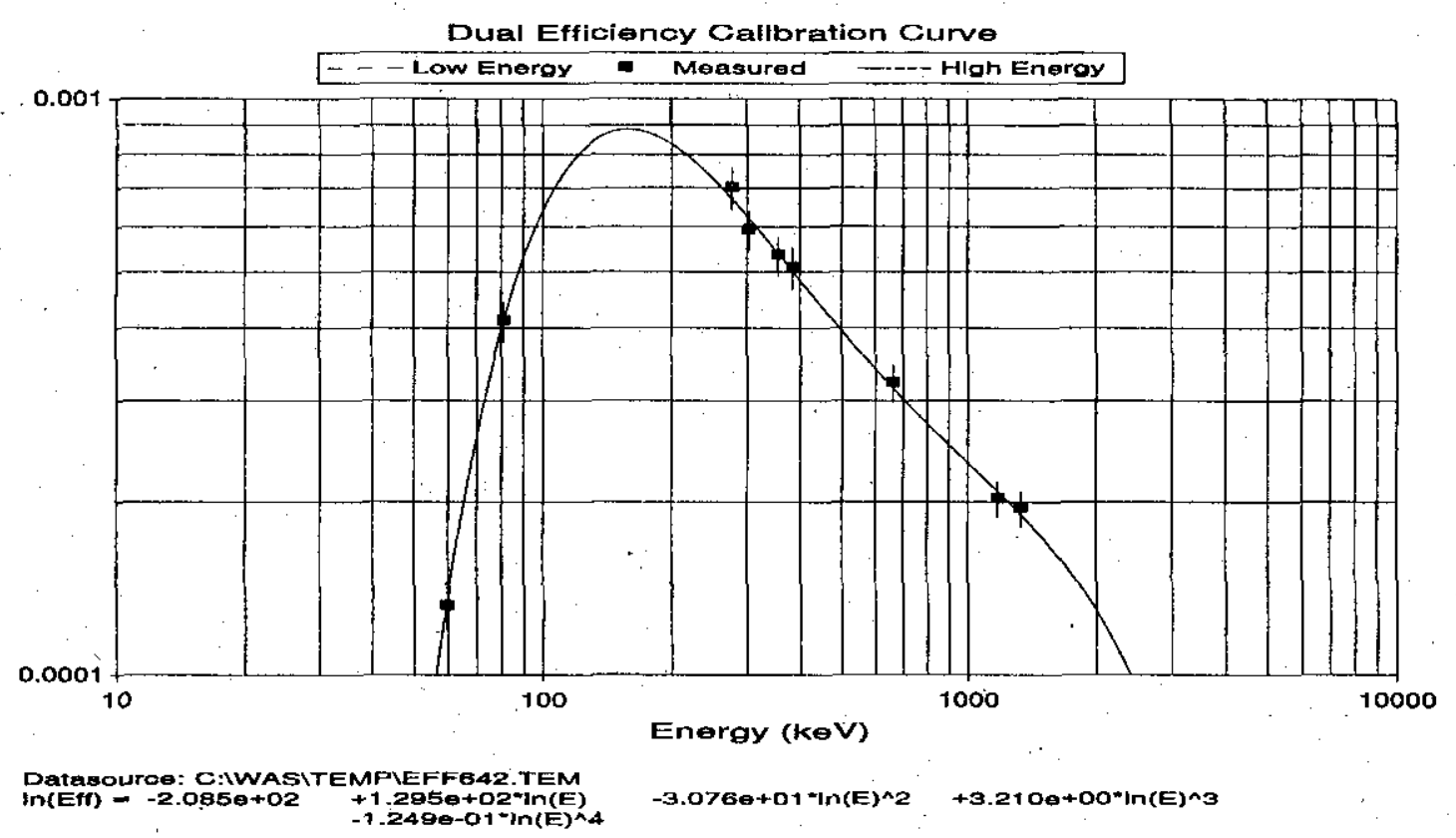

Seg 5, SEGe 3, Drum position 2. 
HNF-5148, Rev. 2

Foam Drum, density $=0.01346 \mathrm{gms} / \mathrm{cc}$, No Shield (collimator). Spectrum Seq \# 3988

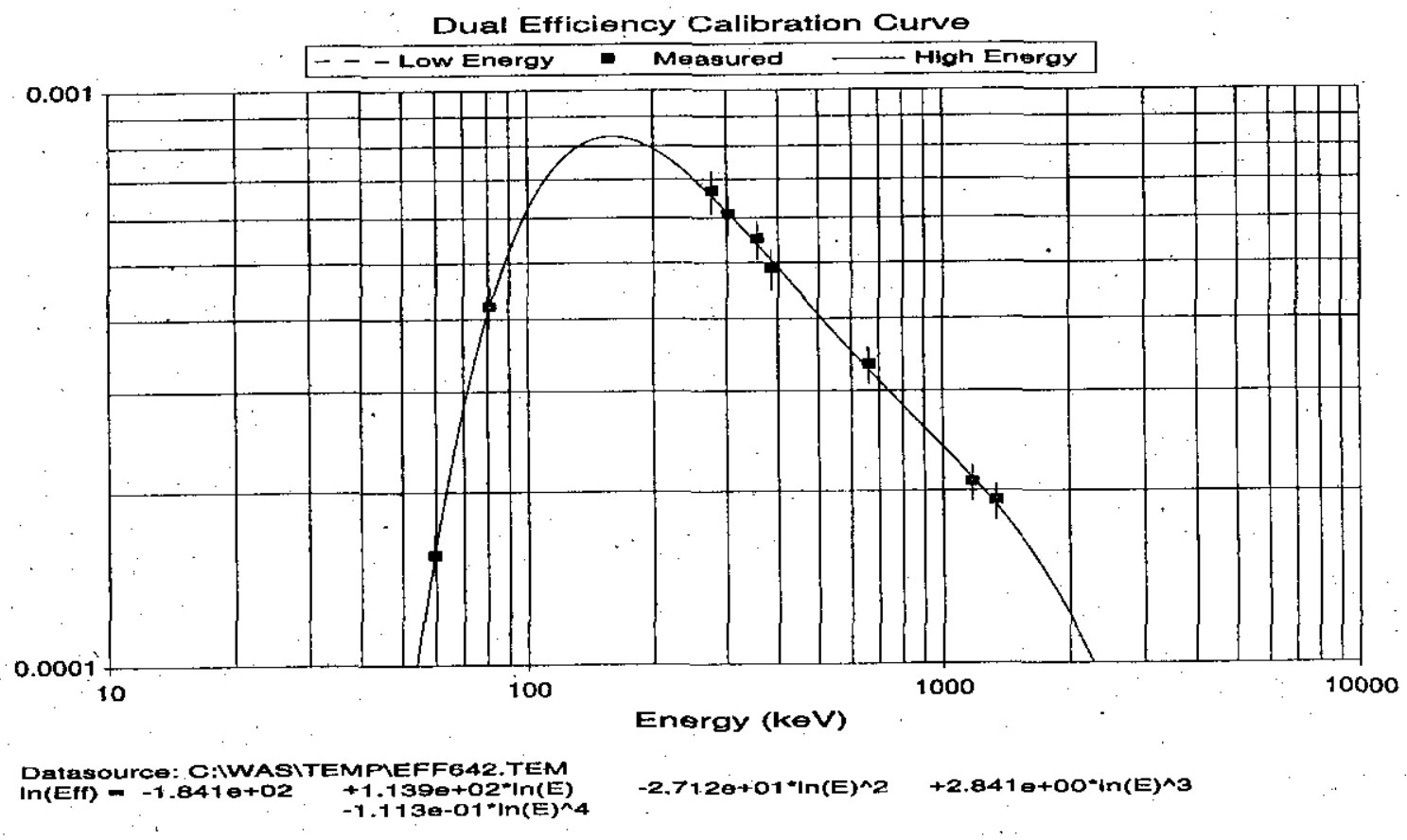

Seg 6, SEGe 3, Drum position 3.

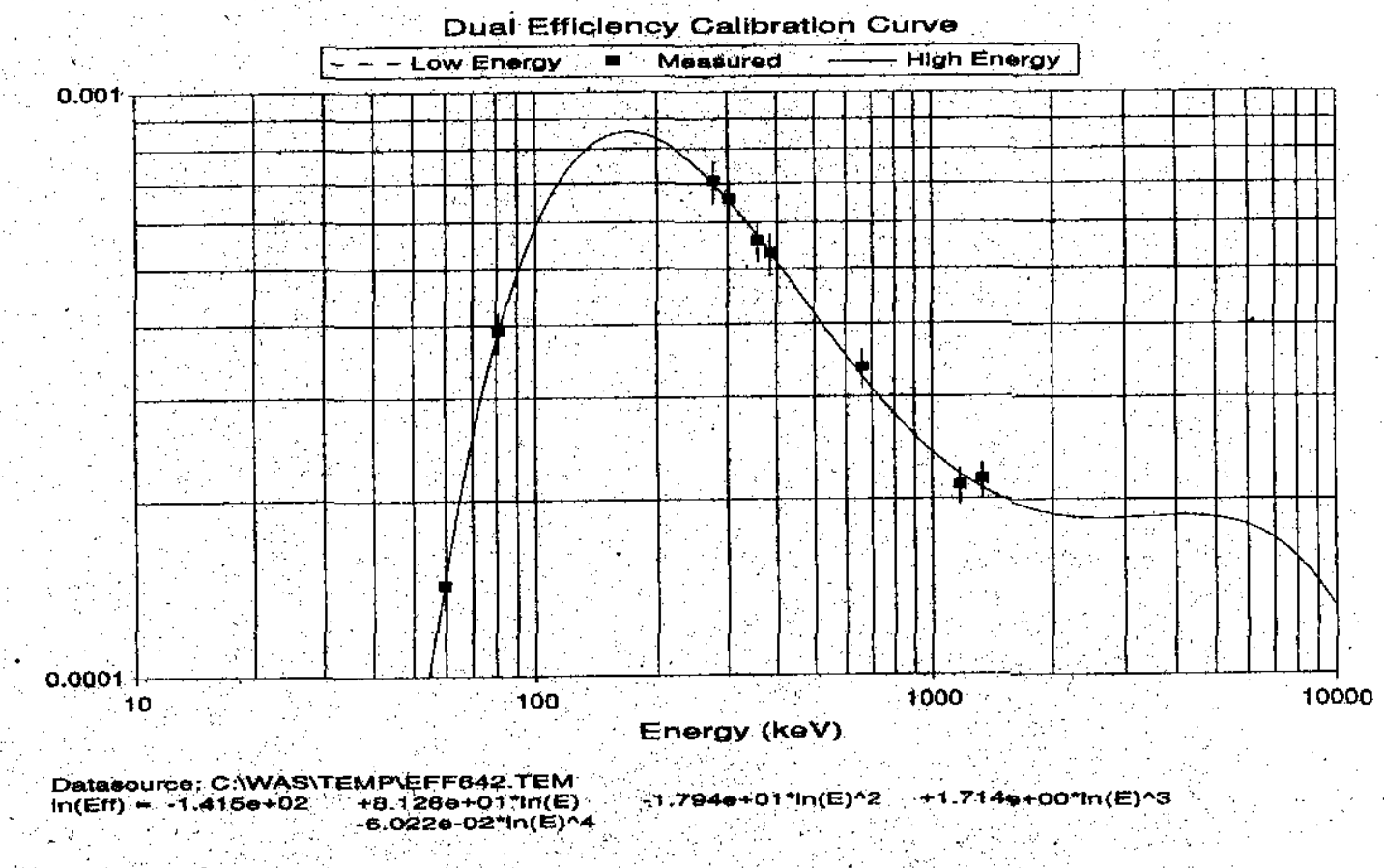

Seg 7, SEGe 2, Drum position 1. 
HNF-5148, Rev. 2

Foam Drum, density $=0.01346 \mathrm{gms} / \mathrm{cc}$, No Shield (collimator). Spectrum Seq \# 3988

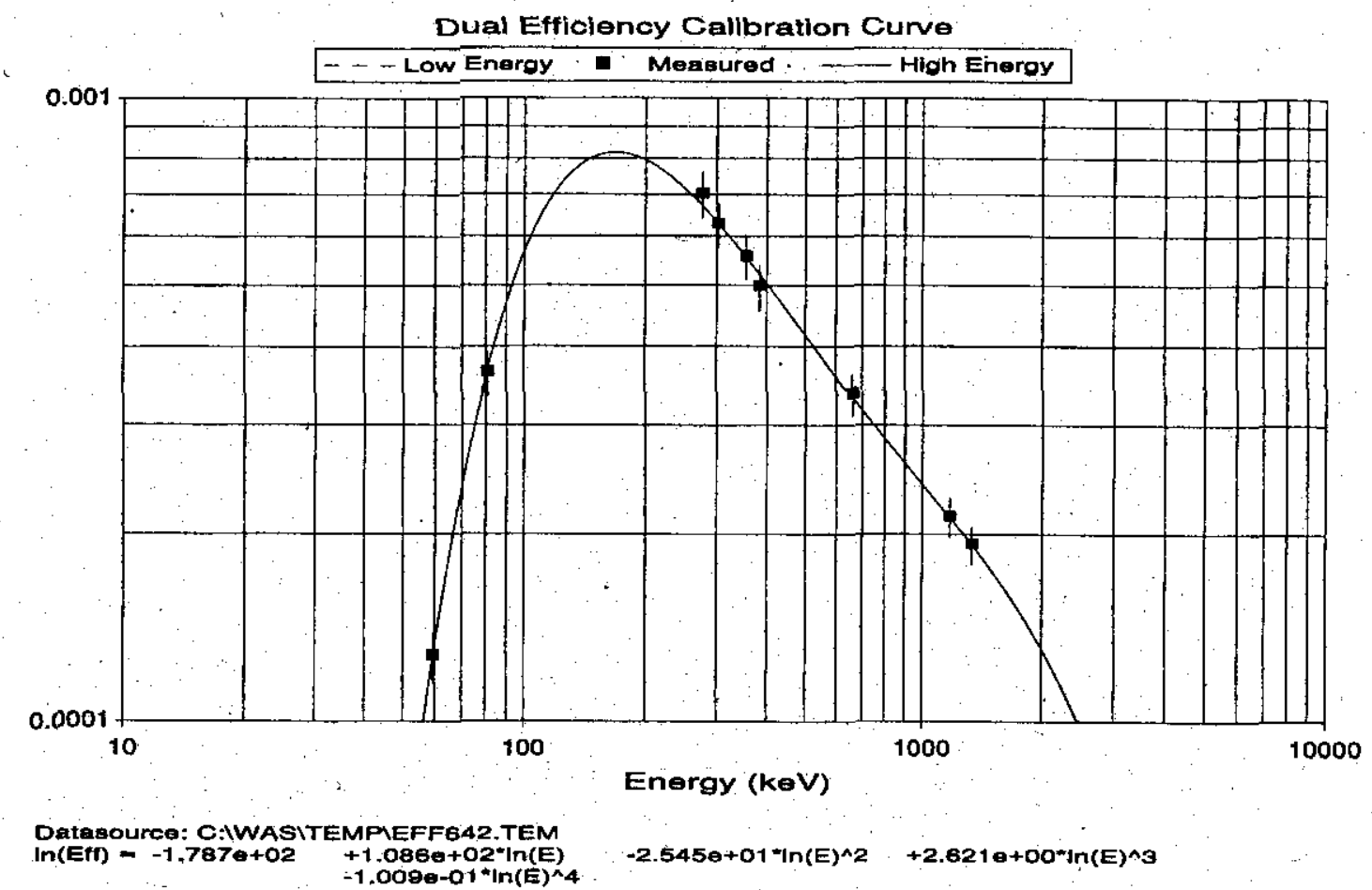

Seg 8, SEGe 2, Drum position 2.

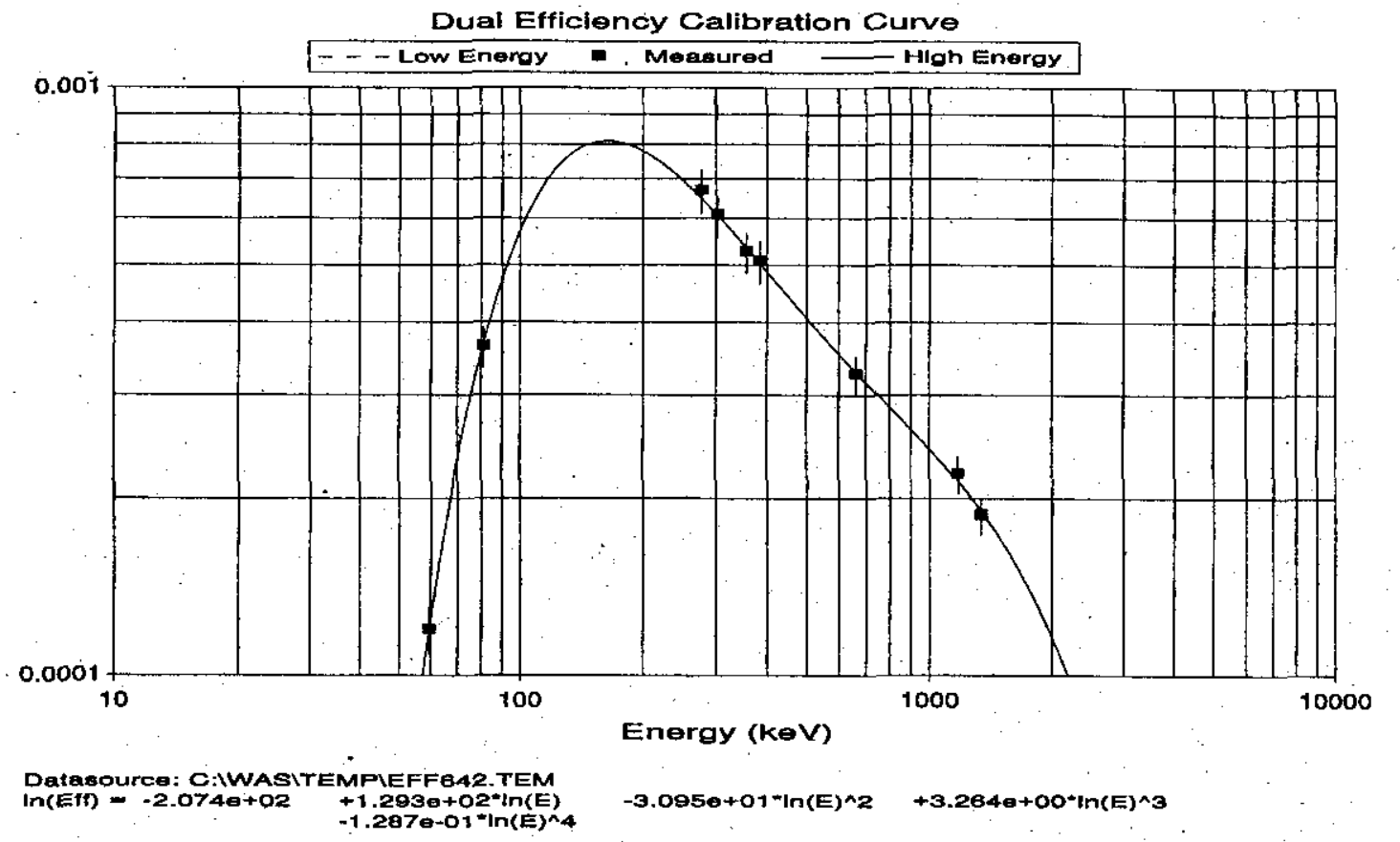

Seg 9, SEGe 2, Drum position 3. 
Foam Drum, density $=0.01346 \mathrm{gms} / \mathrm{cc}$, No Shield (collimator). Spectrum Seq \#3988

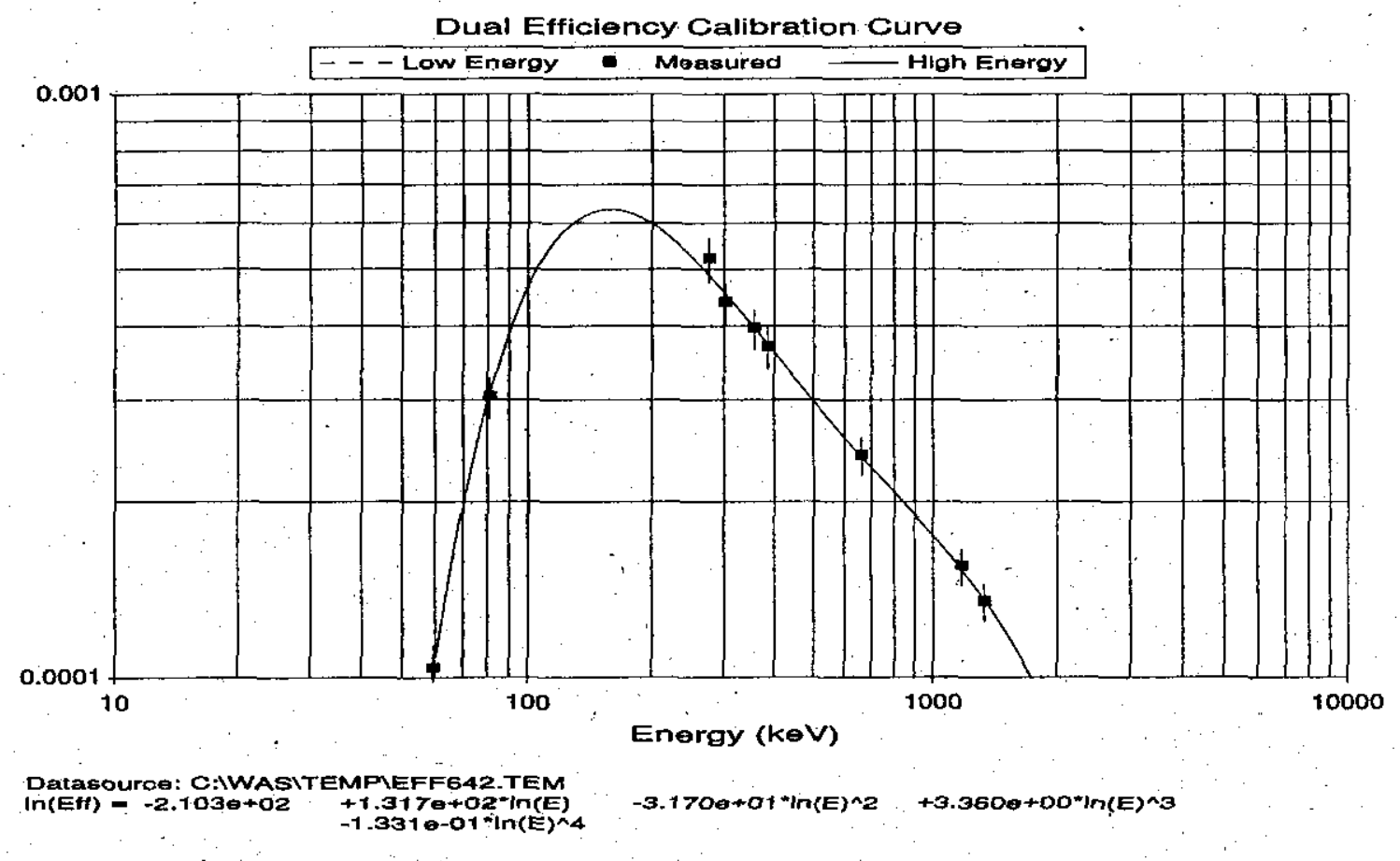

Seg 10, SEGe 1, Drum position 1.

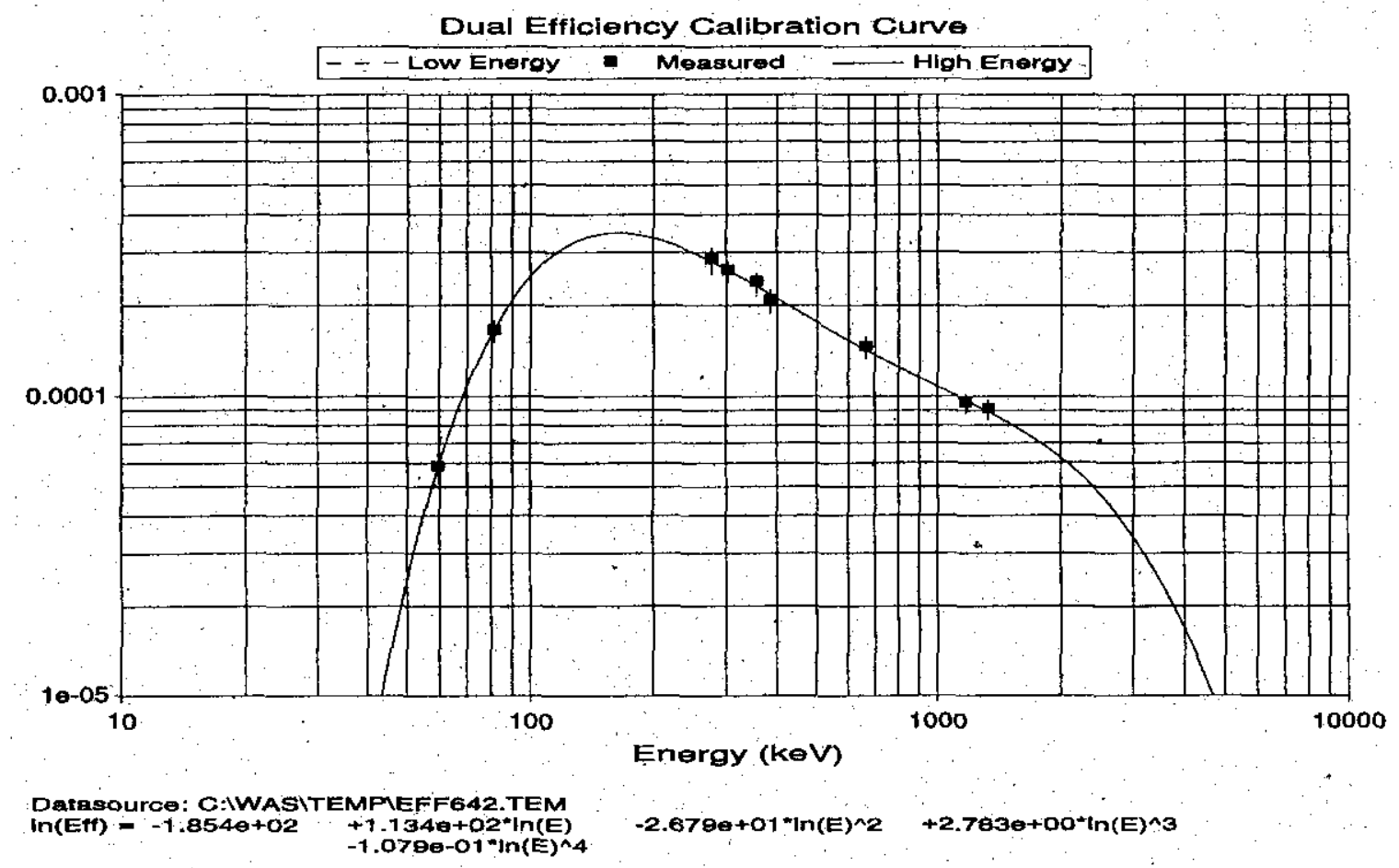

Seg 11, SEGe 1, Drum position 2. 
HNF-5148, Rev. 2

Foam Drum, density $=0.01346$ gms $/ \mathrm{cc}$, No Shield (collimator). Spectrum Seq \# 3988

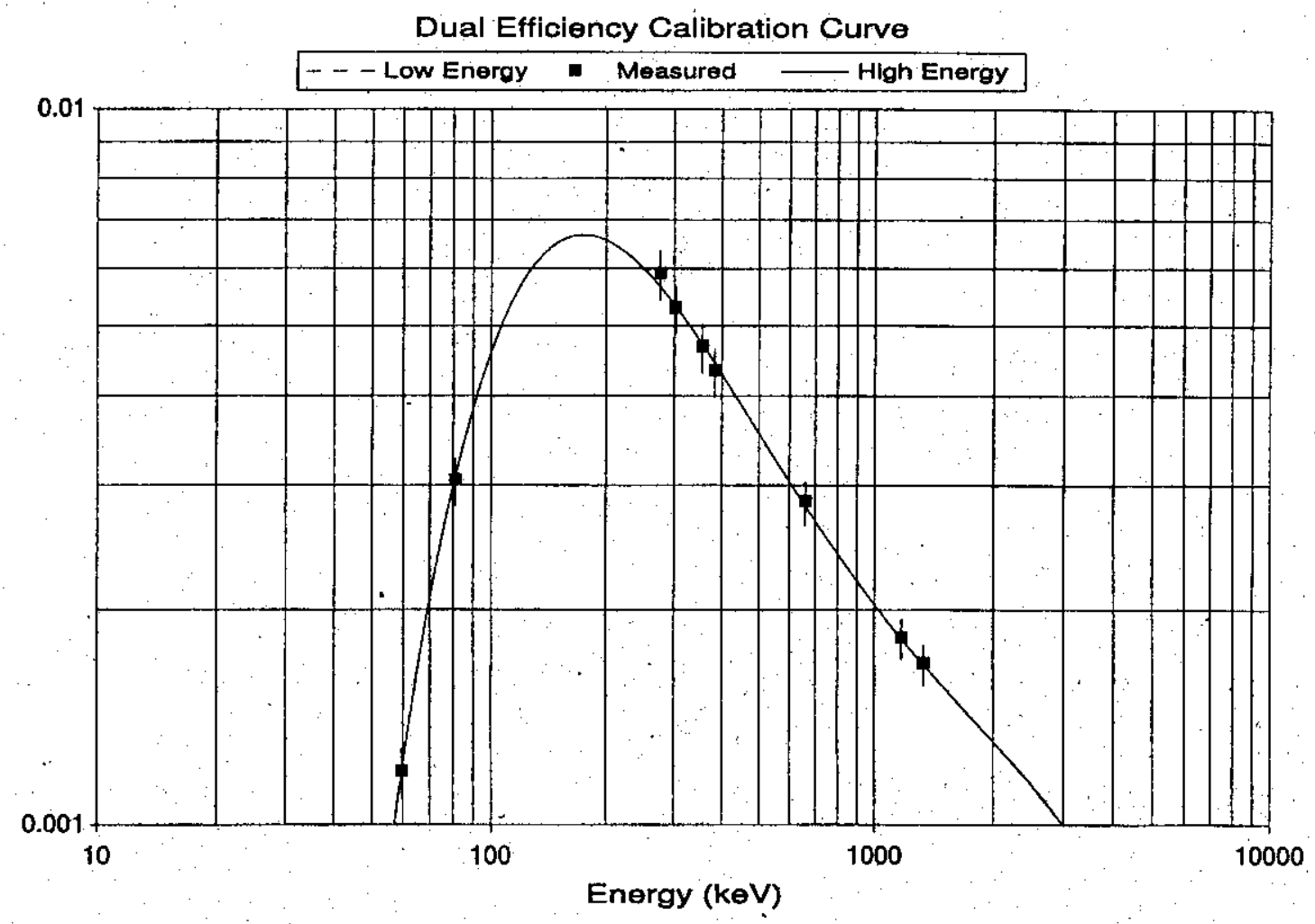

Datasource: C:IWASITEMPIEFF642.TEM $\ln (E f f)=-1.374 \theta+02 \quad+8.105 \theta+01 * \ln (E)$ $-6.551 \theta-02^{*} \operatorname{In}(E)^{\wedge}$

Sum Segments. 
HNF-5148, Rev. 2

Foam Drum, density $=0.01346 \mathrm{gms} / \mathrm{cc}$, Shield (collimator). Spectrum Seq \# 3989

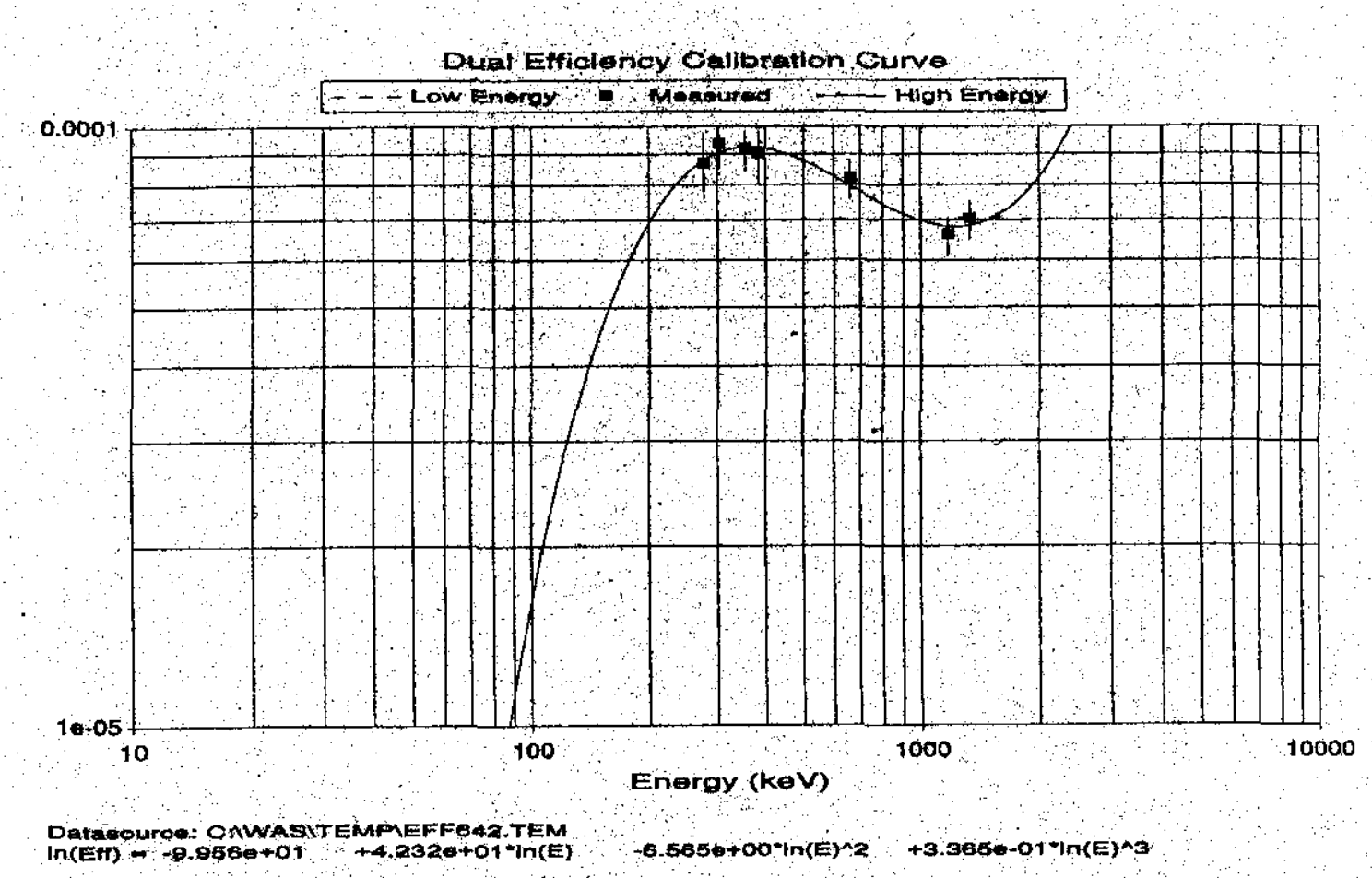

Seg 2, SEGe 4, Drum position 2.

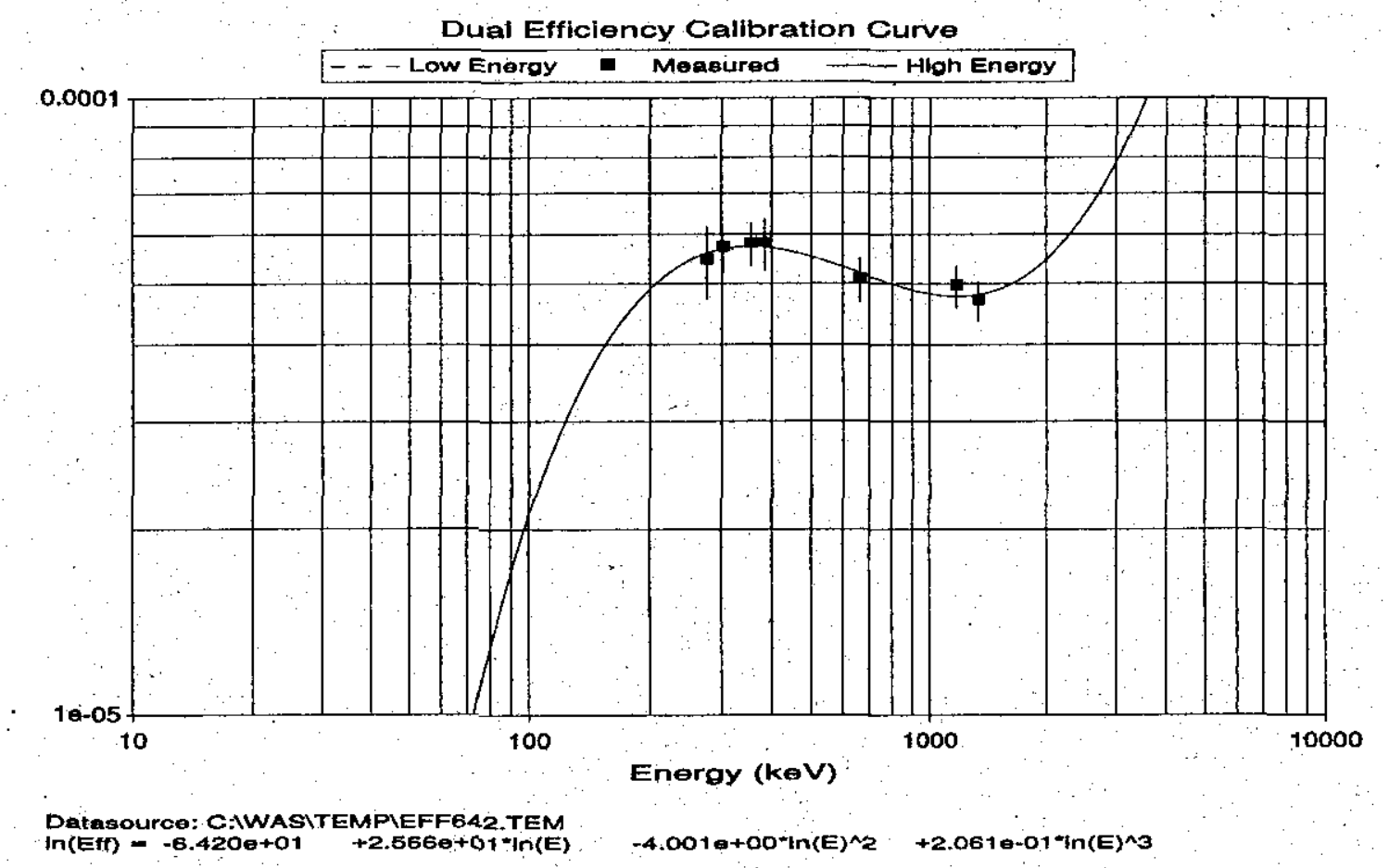

Seg 3, SEGe 4, Drum positon 3. 
HNF-5148, Rev. 2

Foam Drum, density $=0.01346 \mathrm{gms} / \mathrm{cc}$, Shield (collimator). Spectrum Seq \# 3989

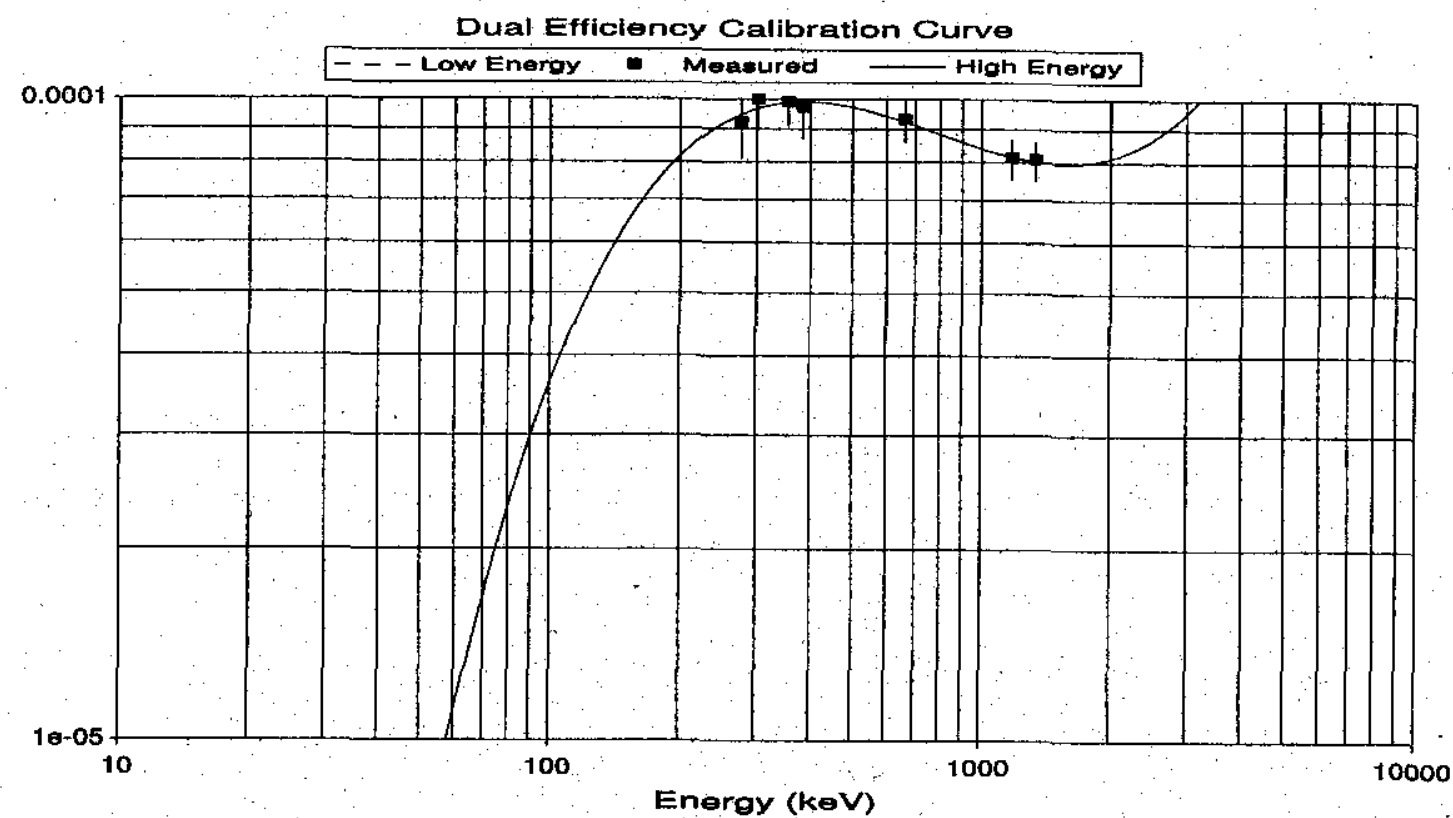

Datasourco: C:IWASITEMPIEFFG42.TEM

$\operatorname{In}\left(\right.$ Eff $--5.473 \theta+01 \quad .+2.092 \theta+01+\ln (E) \quad-3.175 \theta+00-\ln (E)^{\wedge} 2+1.5890-01-\operatorname{In}(E)^{\wedge} 3$

Seg 4, SEGe 3, Drum position 1.

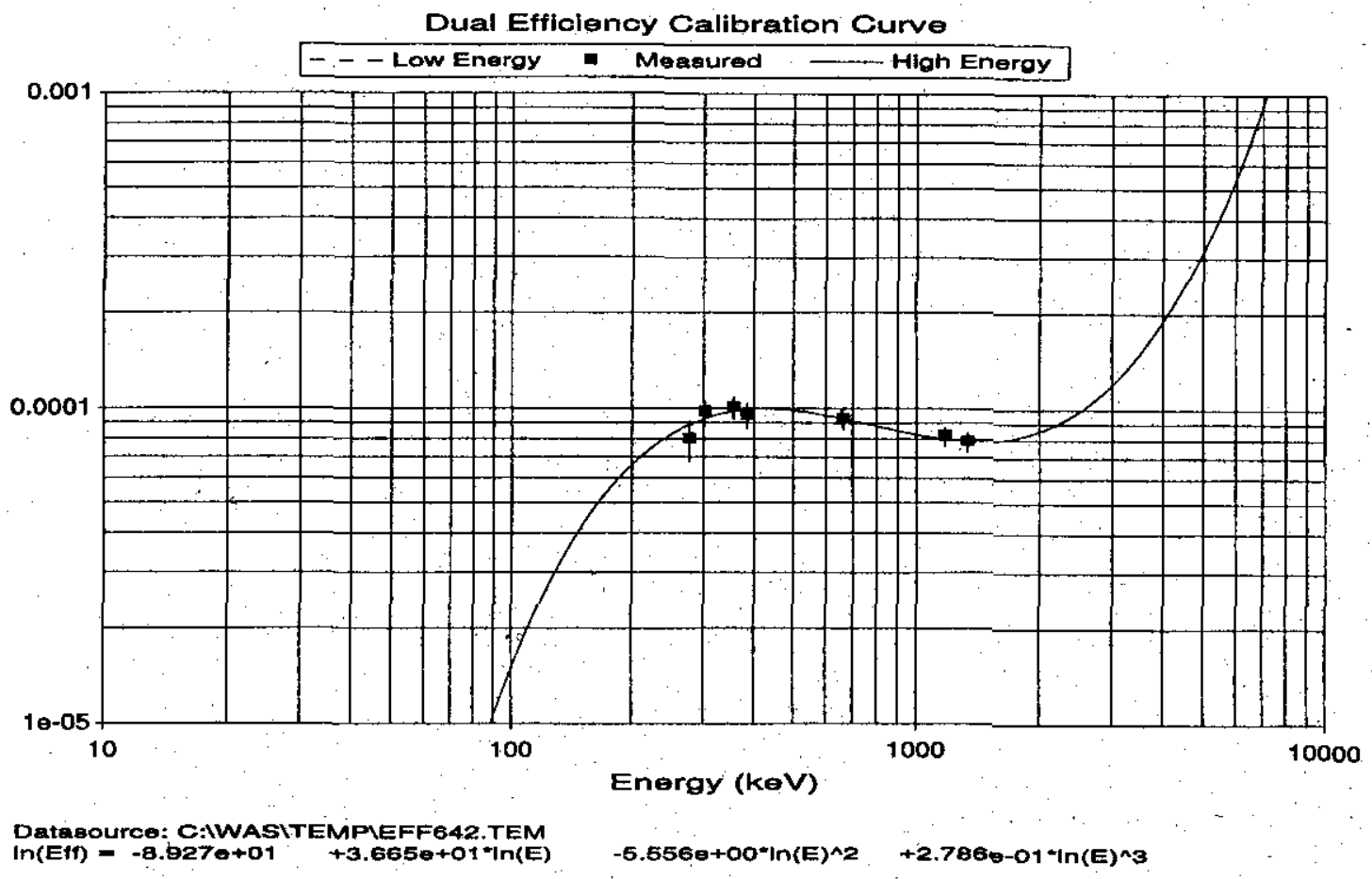

Seg 5, SEGe 3, Drum position 2. 
HNF-5148, Rev. 2

Foam Drum, density $=0.01346 \mathrm{gms} / \mathrm{cc}$, Shield (collimator). Spectrum Seq \# 3989

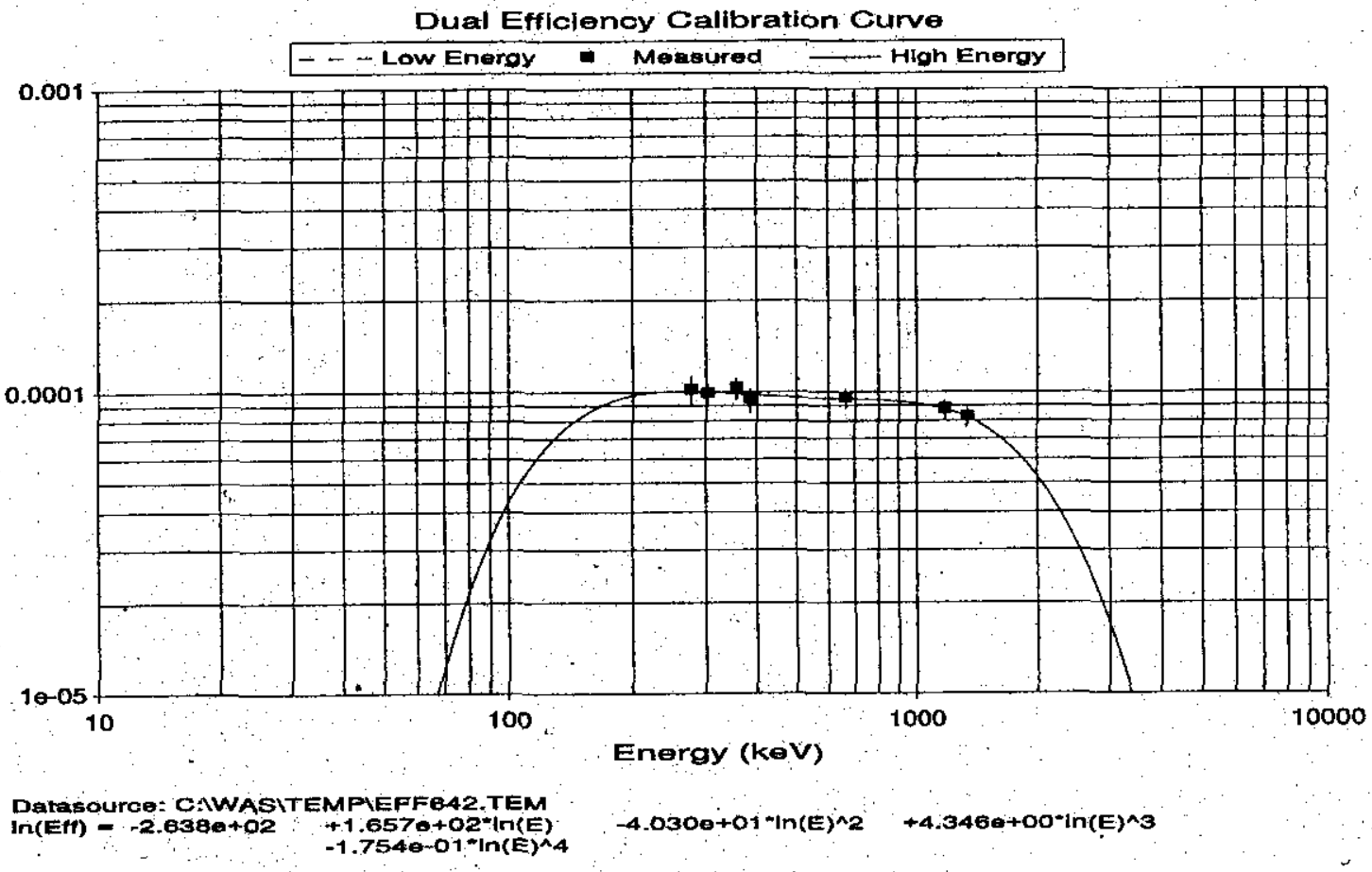

Seg 6, SEGe 3, Drum position 3.

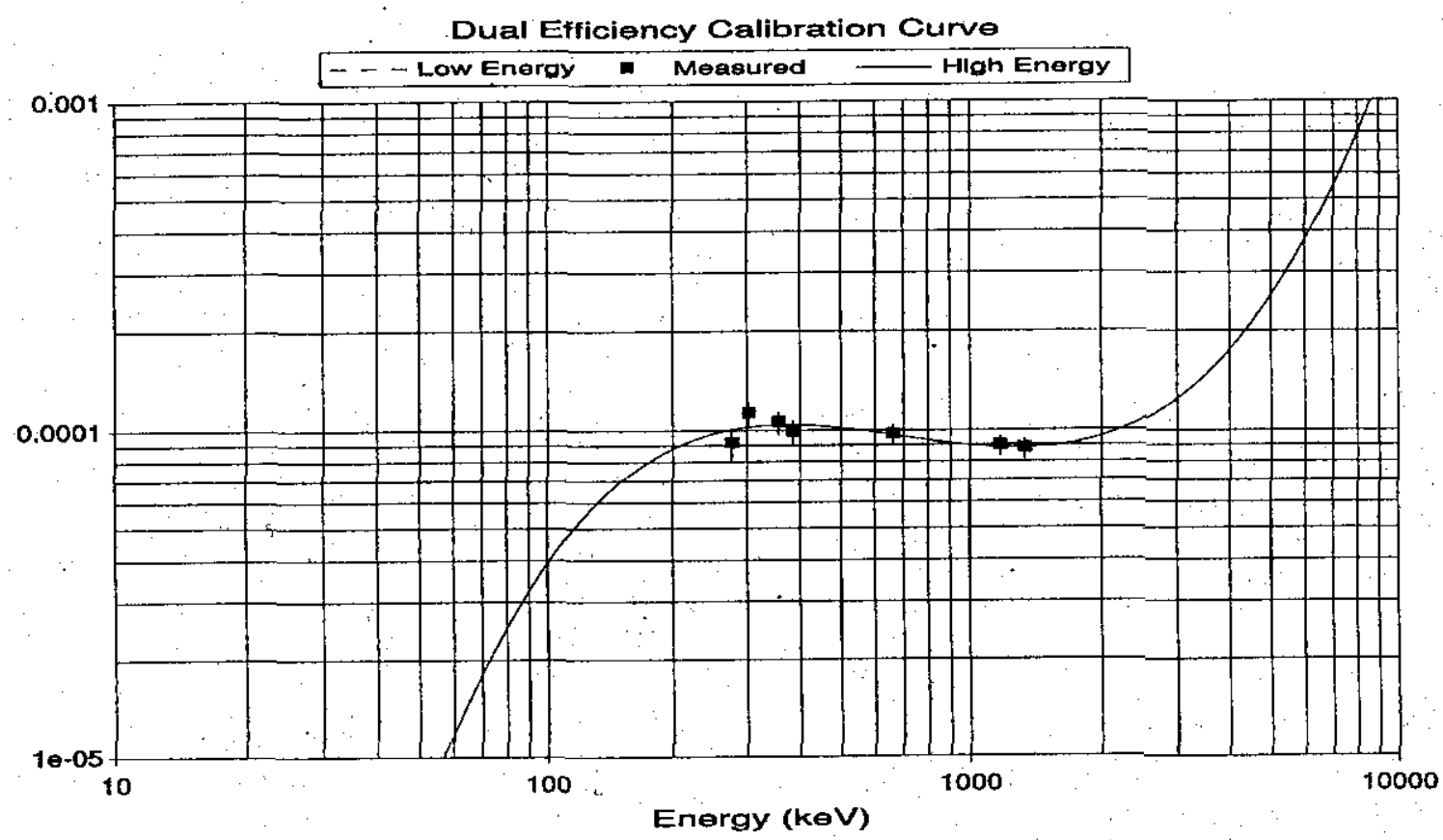

Datasource: C:IWASITEMPEFF 642.TEM $\ln (E f)=-5.764 e+01+2.261 \theta+01 * \operatorname{In}(E)$

$-3.480 \theta+00^{*} \operatorname{In}(E)^{\wedge} 2 \quad+1.779 \theta-01 * \operatorname{In}(E)^{\wedge}$

Seg 7, SEGe 2, Drum position 1 . 
HNF-5148, Rev. 2

Foam Drum, density $=0.01346 \mathrm{gms} / \mathrm{cc}$, Shield (collimator). Spectrum Seq \# 3989

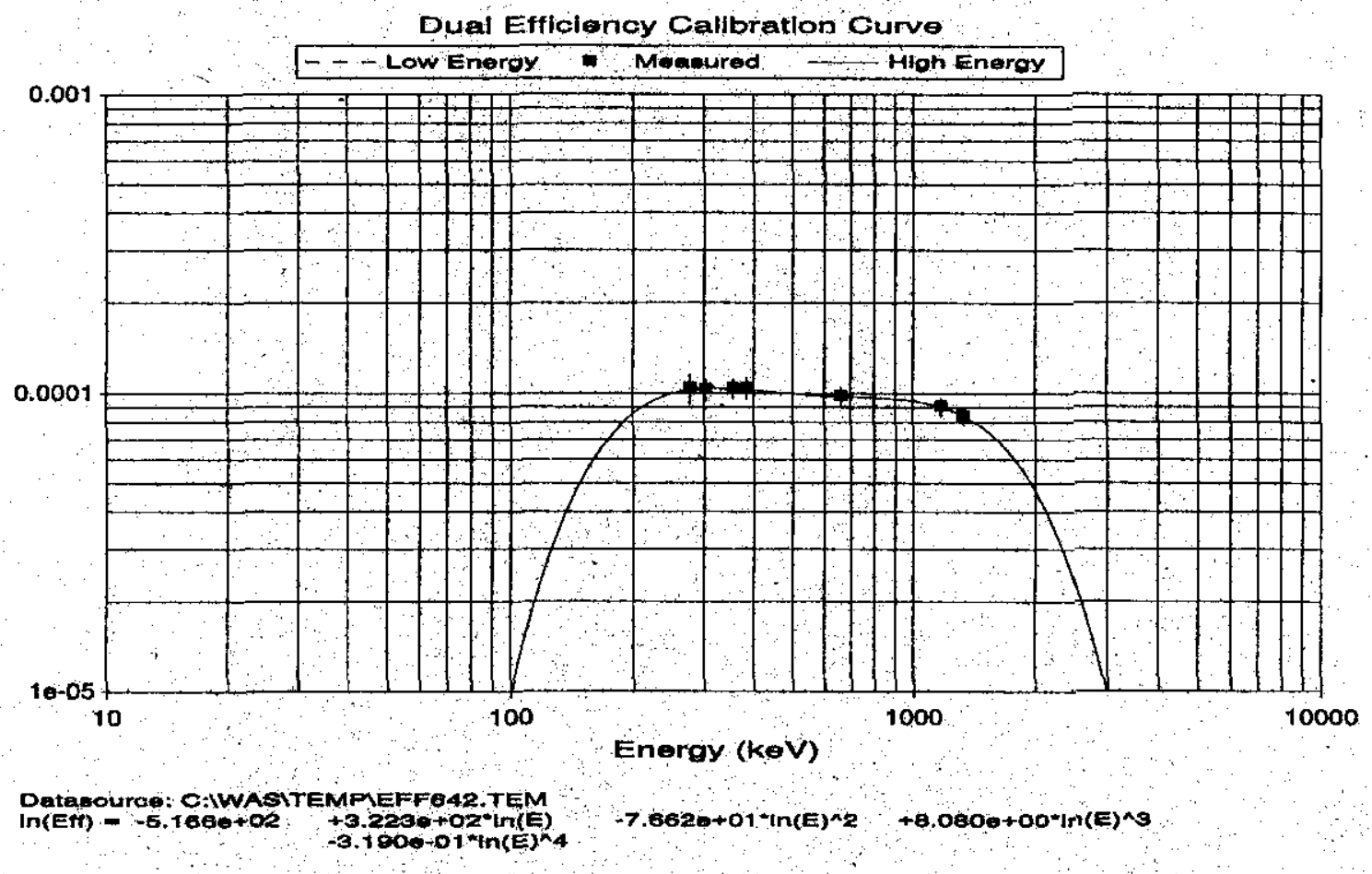

Seg 8, SEGe 2, Drum position 2.

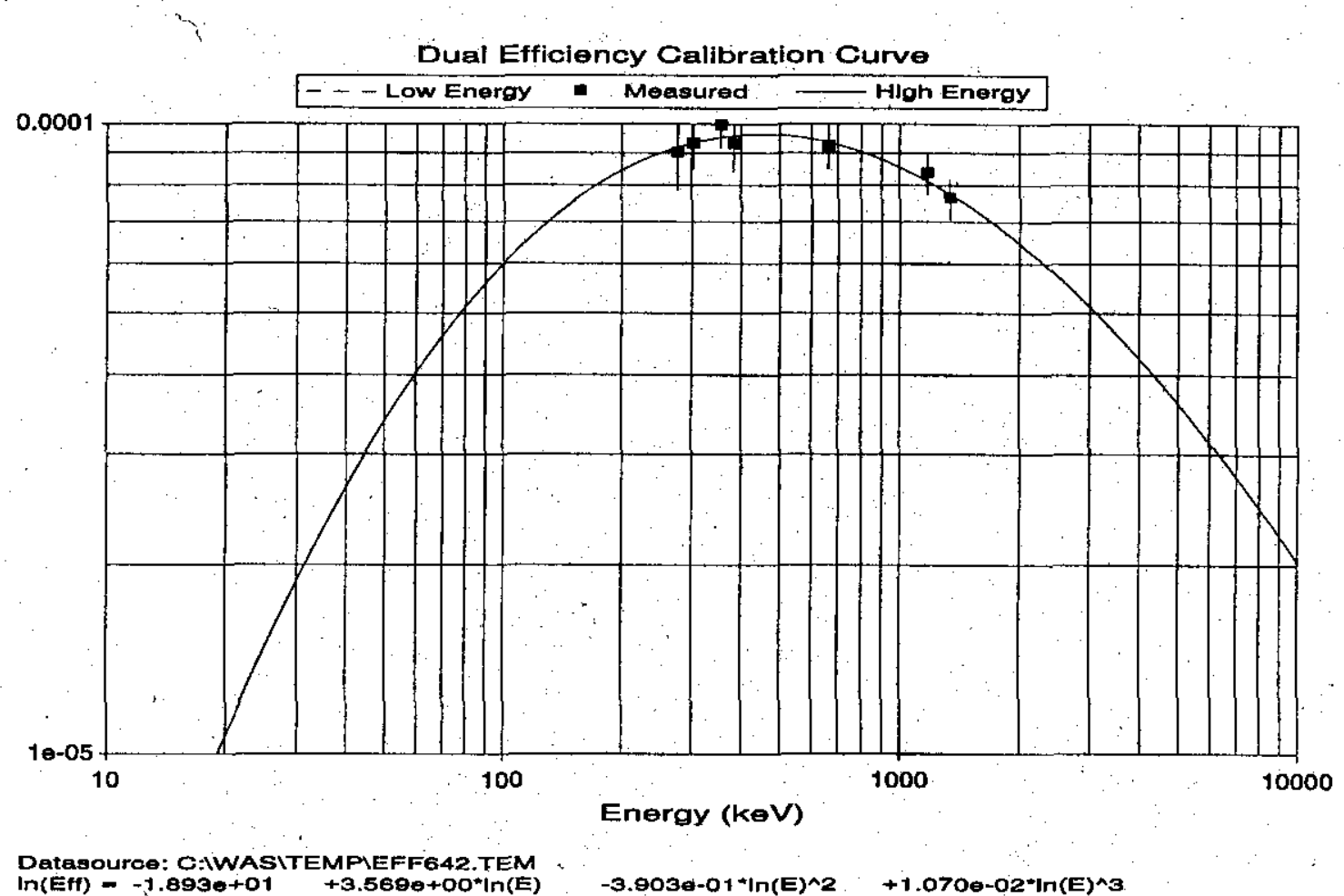

Seg 9, SEGe 2, Drum position 3. 
Foam Drum, density $=0.01346 \mathrm{gms} / \mathrm{cc}$, Shield (collimator). Spectrum Seq \# 3989

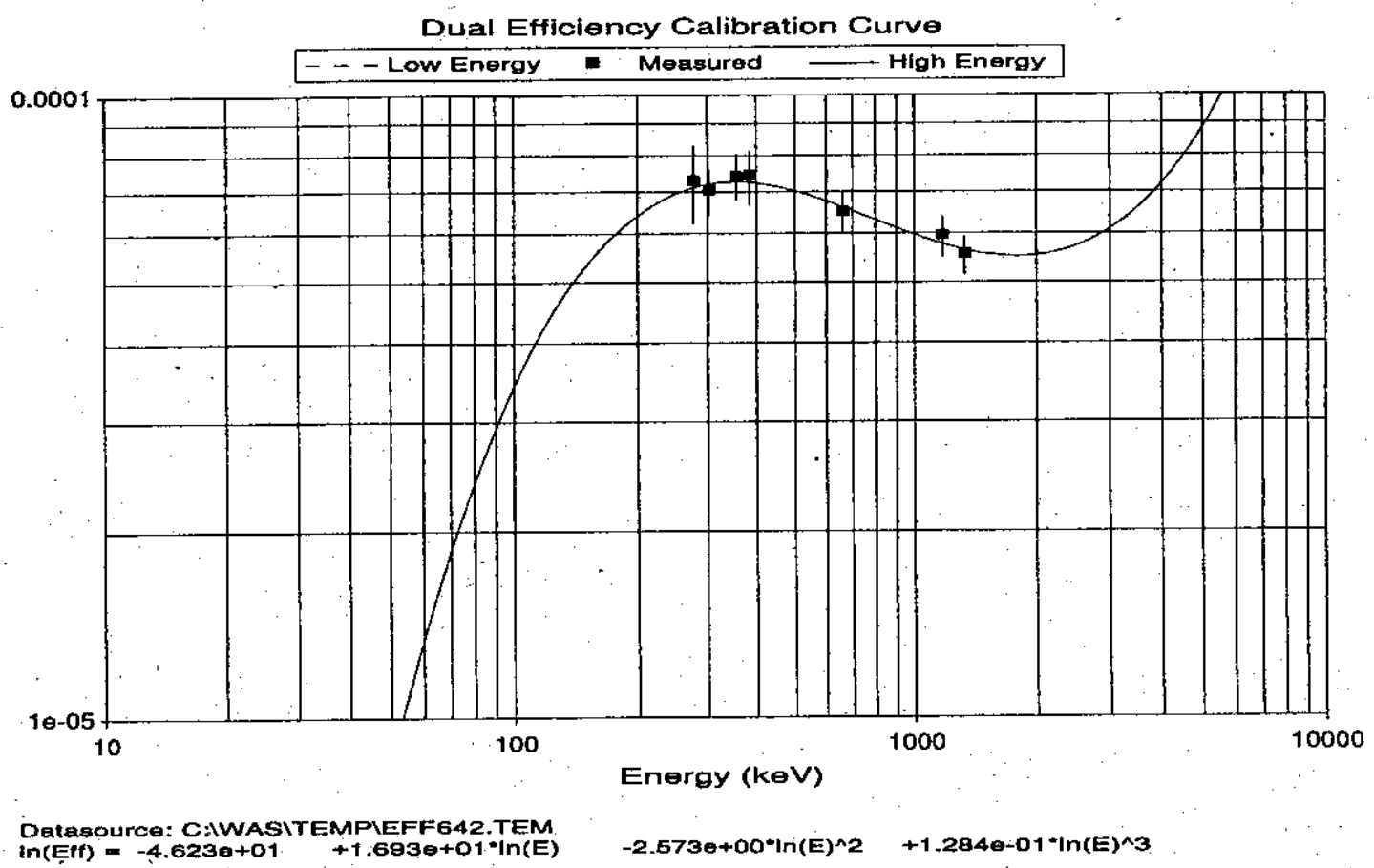

Seg 10, SEGe 1, Drum position 1.

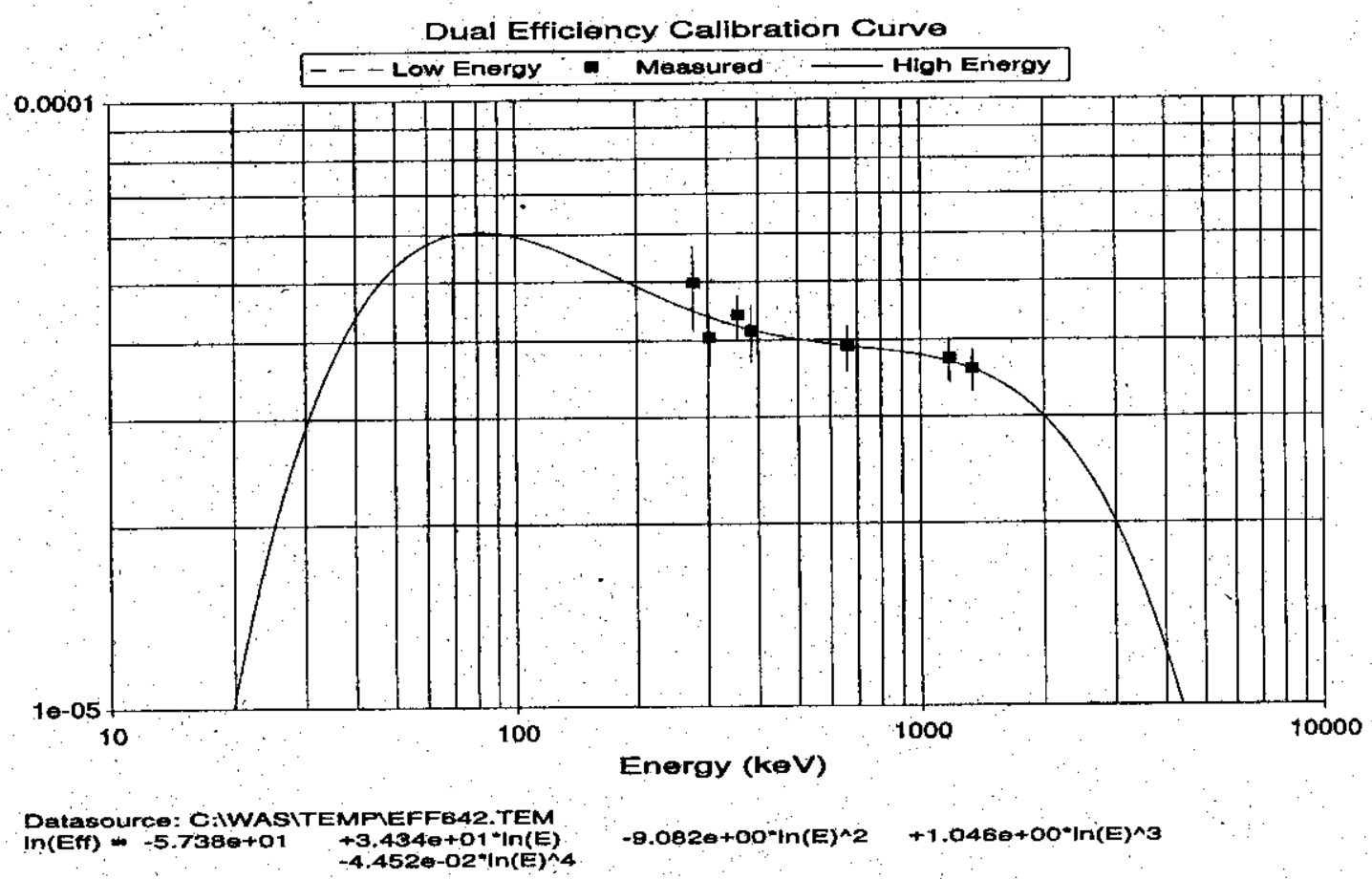

Seg 11, SEGe 1, Drum position 2. 
HNF-5148, Rev. 2

Foam Drum, density $=0.01346$ gms $/ \mathrm{cc}$, Shield (collimator). Spectrum Seq \# 3989

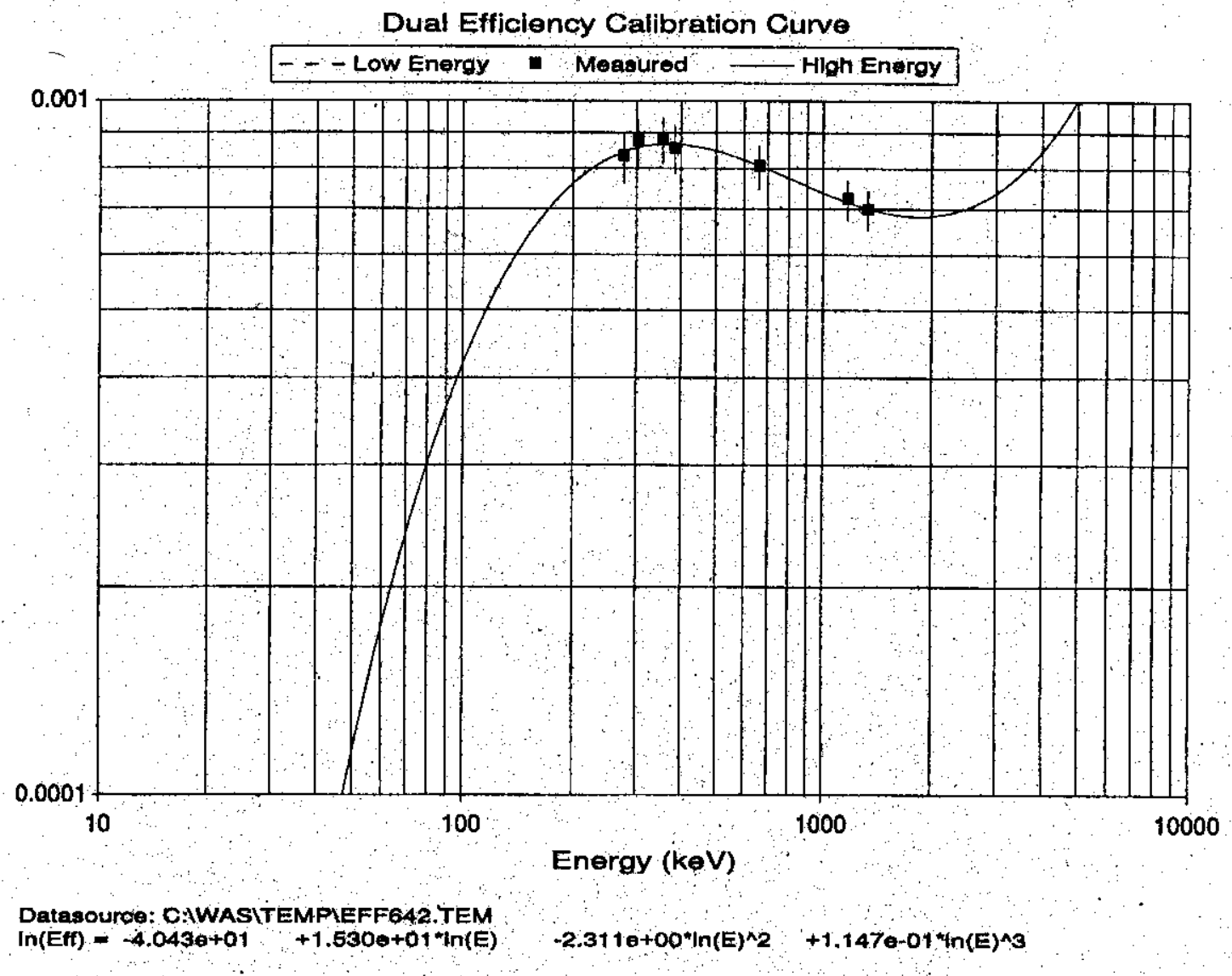


Homosote Drum, density $=0.43029 \mathrm{gms} / \mathrm{cc}$, No Shield (collimator). Spectrum Seq \# 3994

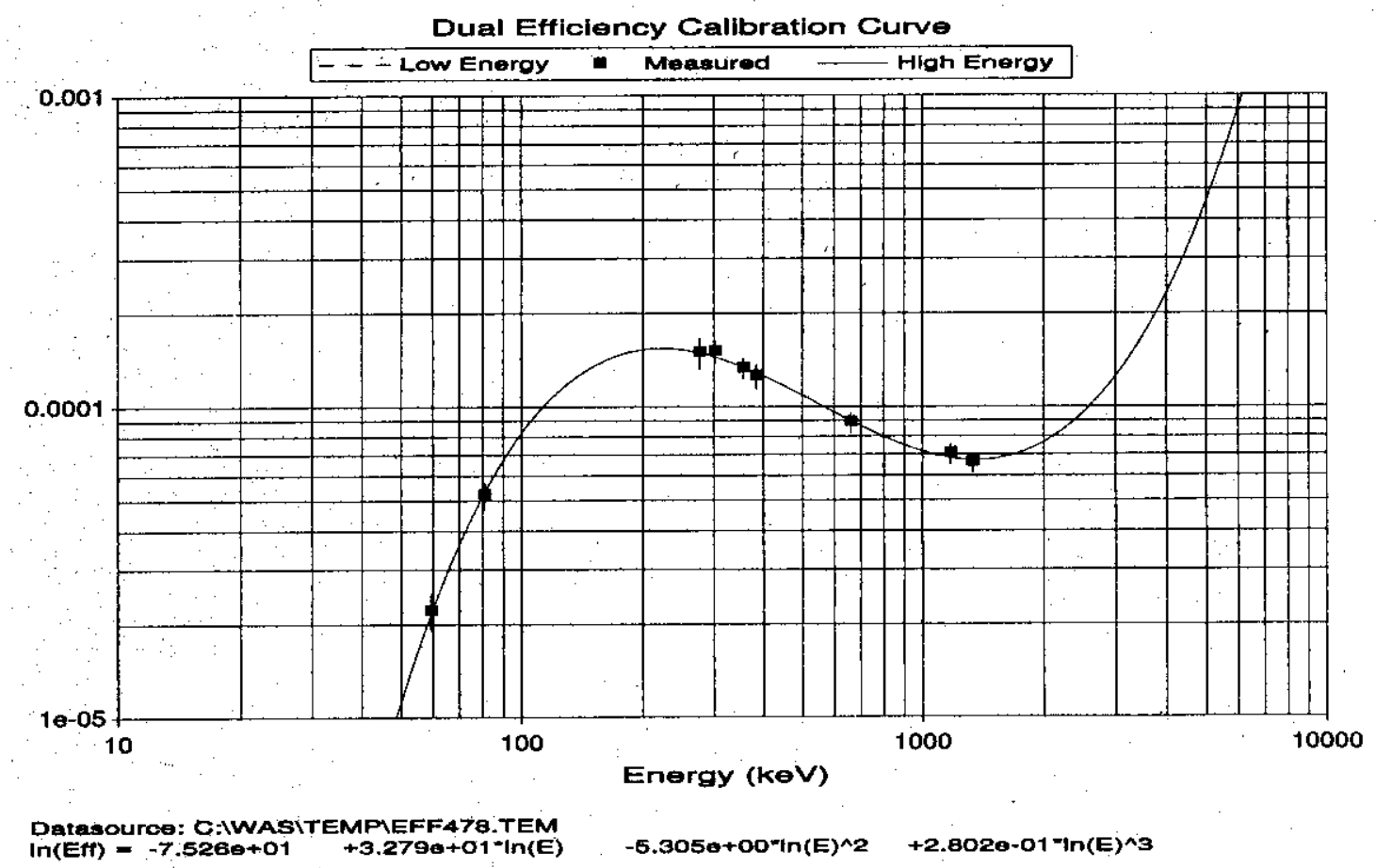

Seg 2, SEGe 4, Drum position 2.

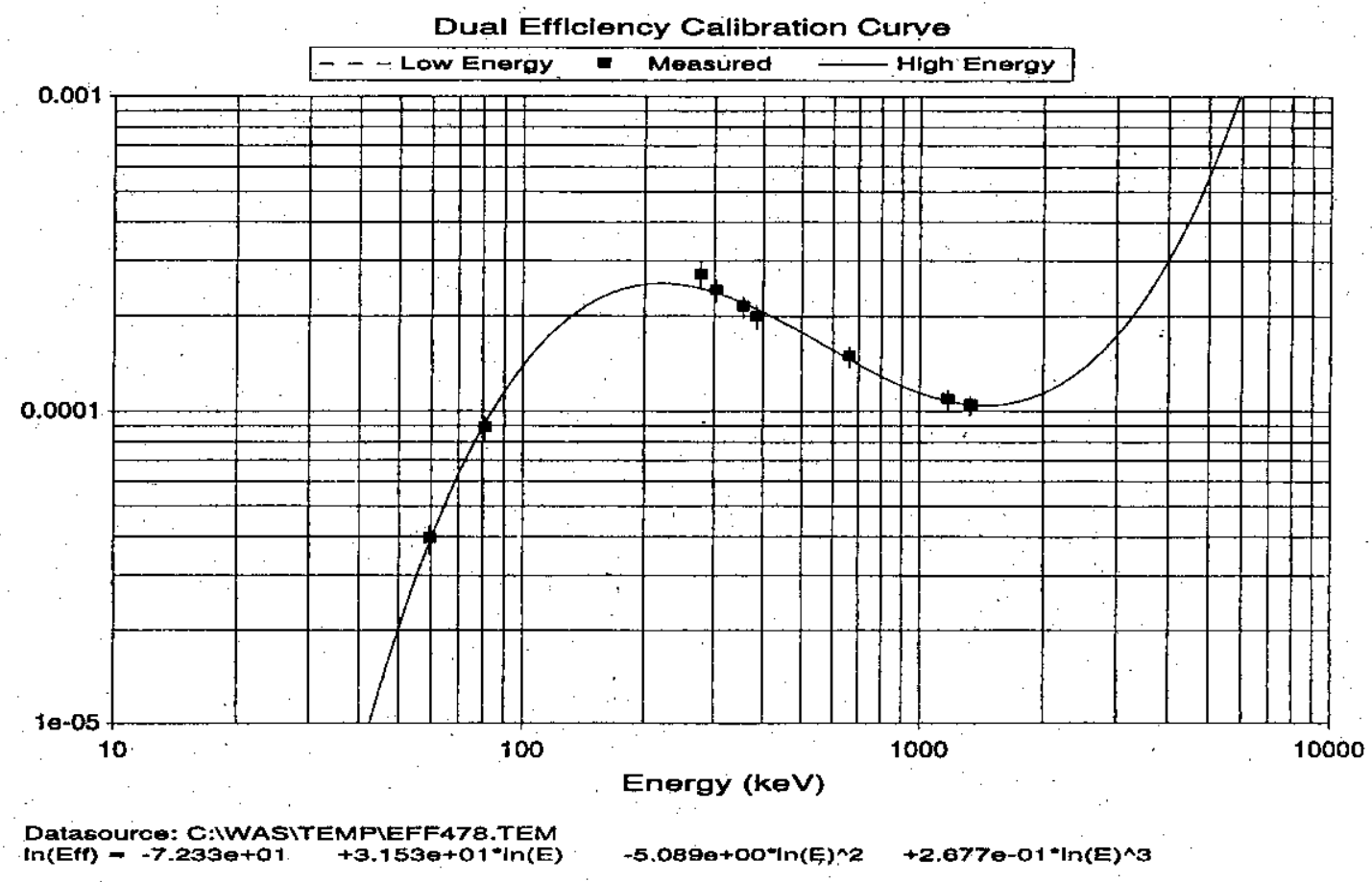

Seg 3, SEGe 4, Drum position 3. 
HNF-5148, Rev. 2

Homosote Drum, density $=0.43029 \mathrm{gms} / \mathrm{cc}$, No Shield (collimator). Spectrum Seq \# 3994

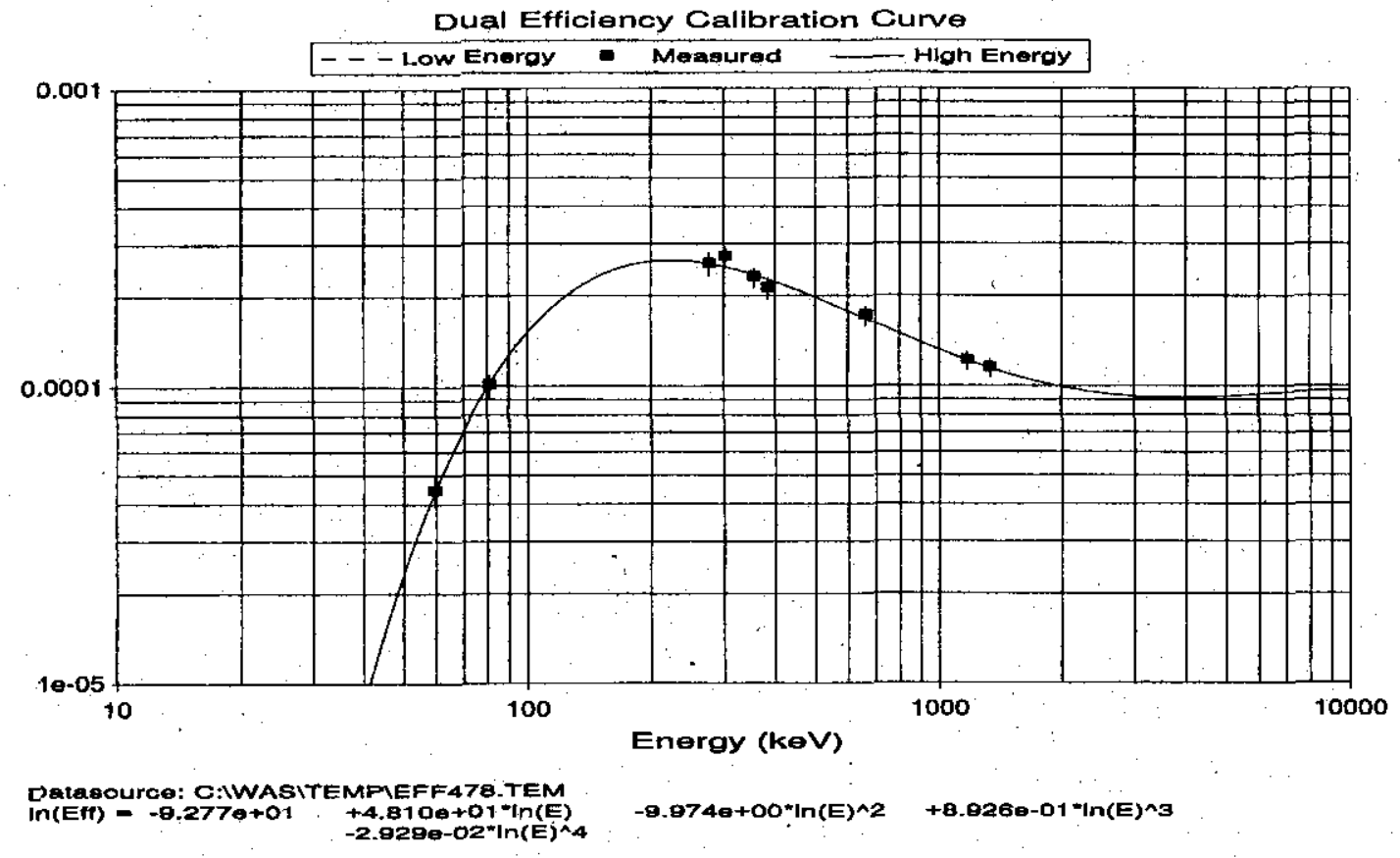

Seg 4, SEGe 3, Drum position 1.

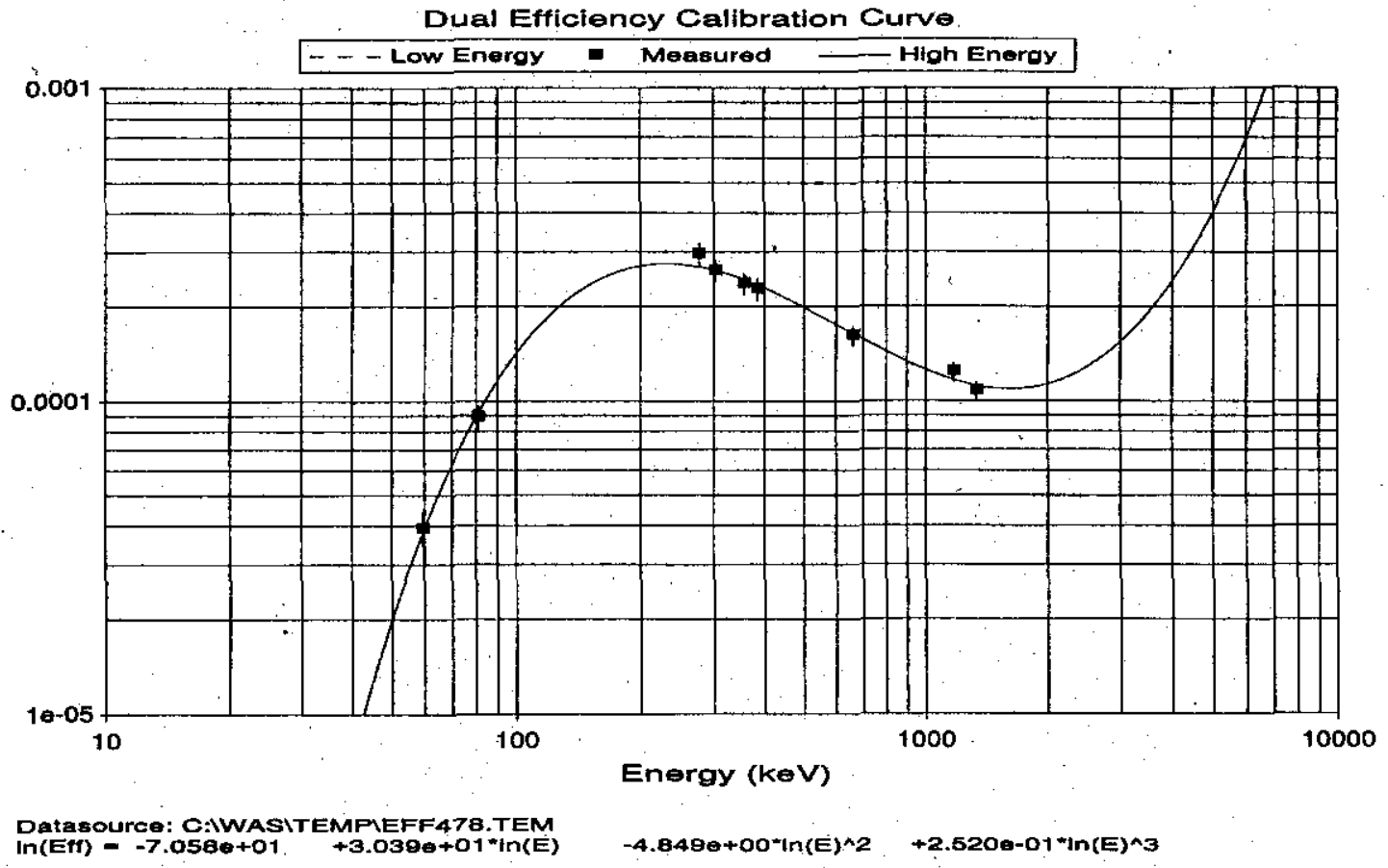

Seg 5, SEGe 3, Drum position 2. 
Homosote Drum, density $=0.43029 \mathrm{gms} / \mathrm{cc}$, No Shield (collimator). Spectrum Seq \# 3994

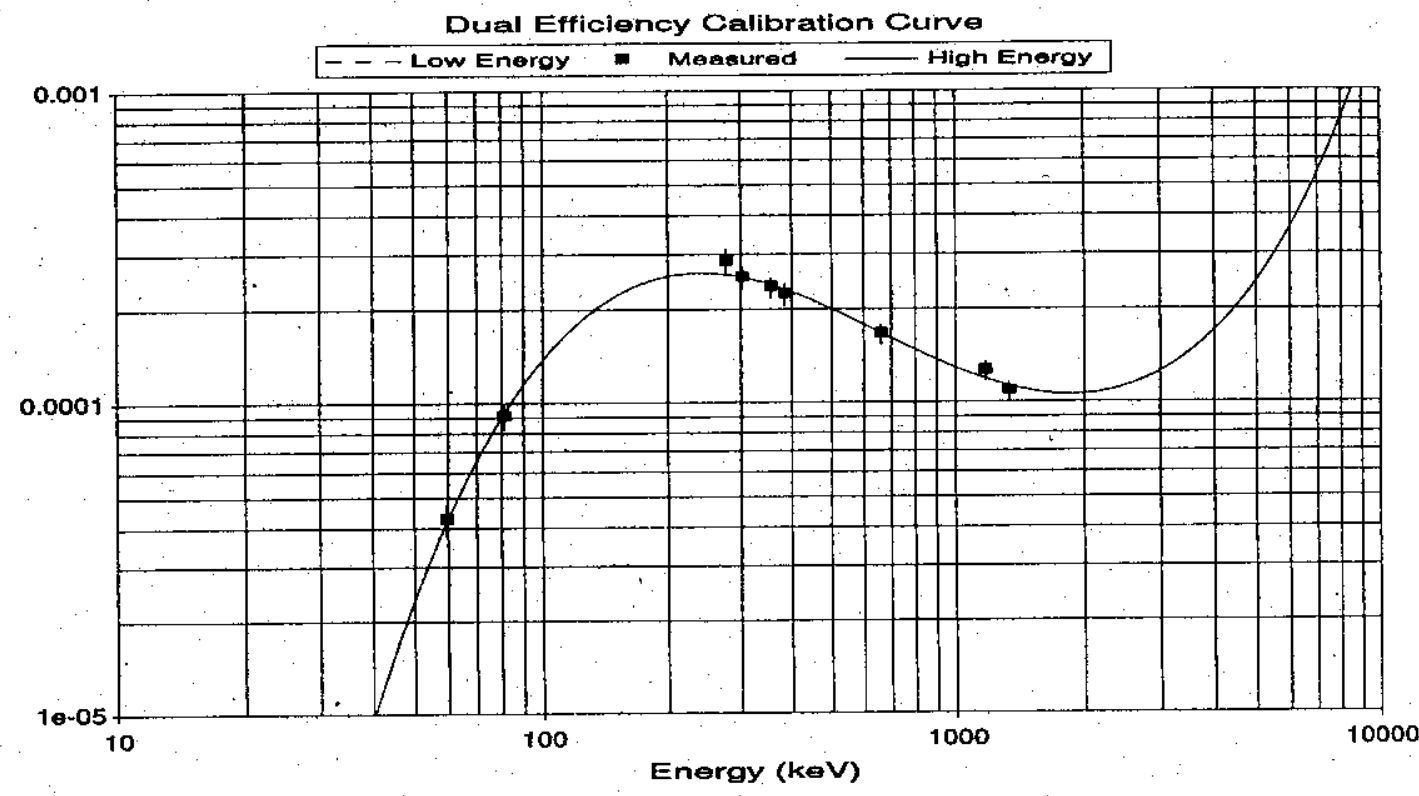

Datasource: O:IWASITEMPIEFF478.TEM $\ln (E f)=-6.2670+01 \quad+2.6160+01 * \ln (E)$

$-4.1230+00^{*} \ln (E)^{\wedge} 2+2.1136 .01 * \ln (E)^{\wedge} 3$ ,

Seg 6, SEGe 3, Drum position 3.

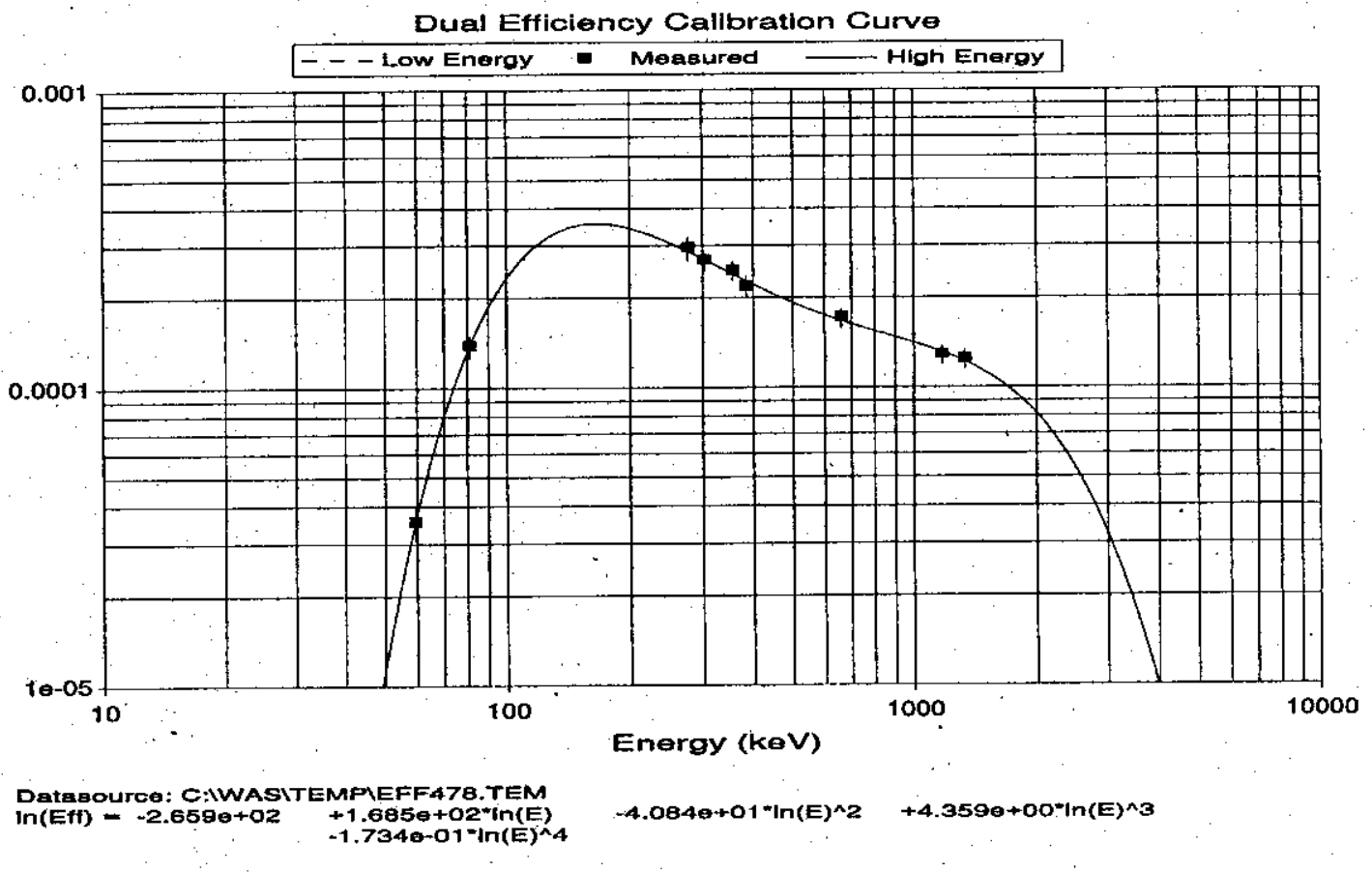

Seg 7, SEGe 2, Drum position 1. 
HNF-5148, Rev. 2

Homosote Drum, density $=0.43029 \mathrm{gms} / \mathrm{cc}$, No Shield (collimator). Spectrum Seq \# 3994

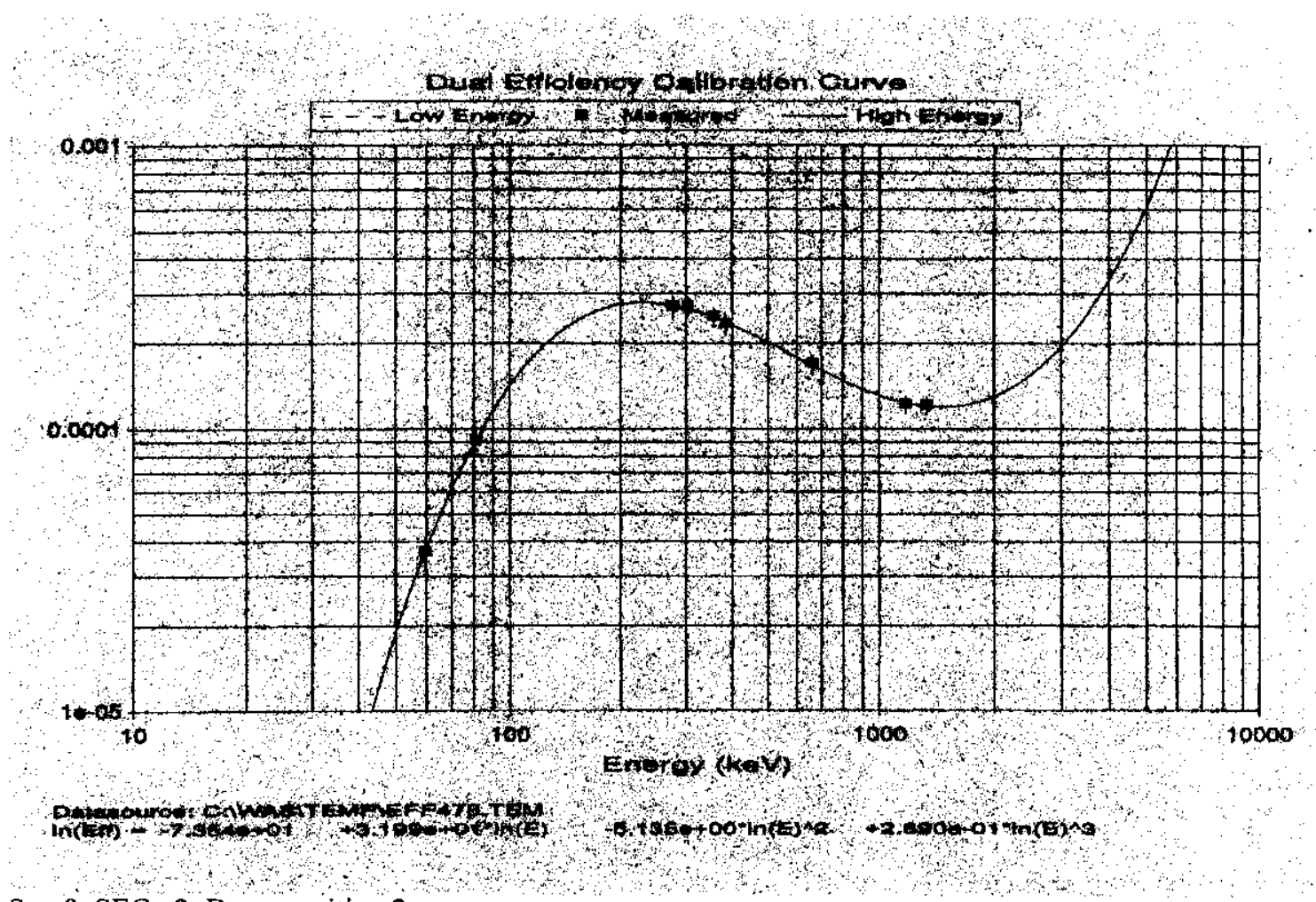

Seg 8, SEGe 2, Drum position 2.

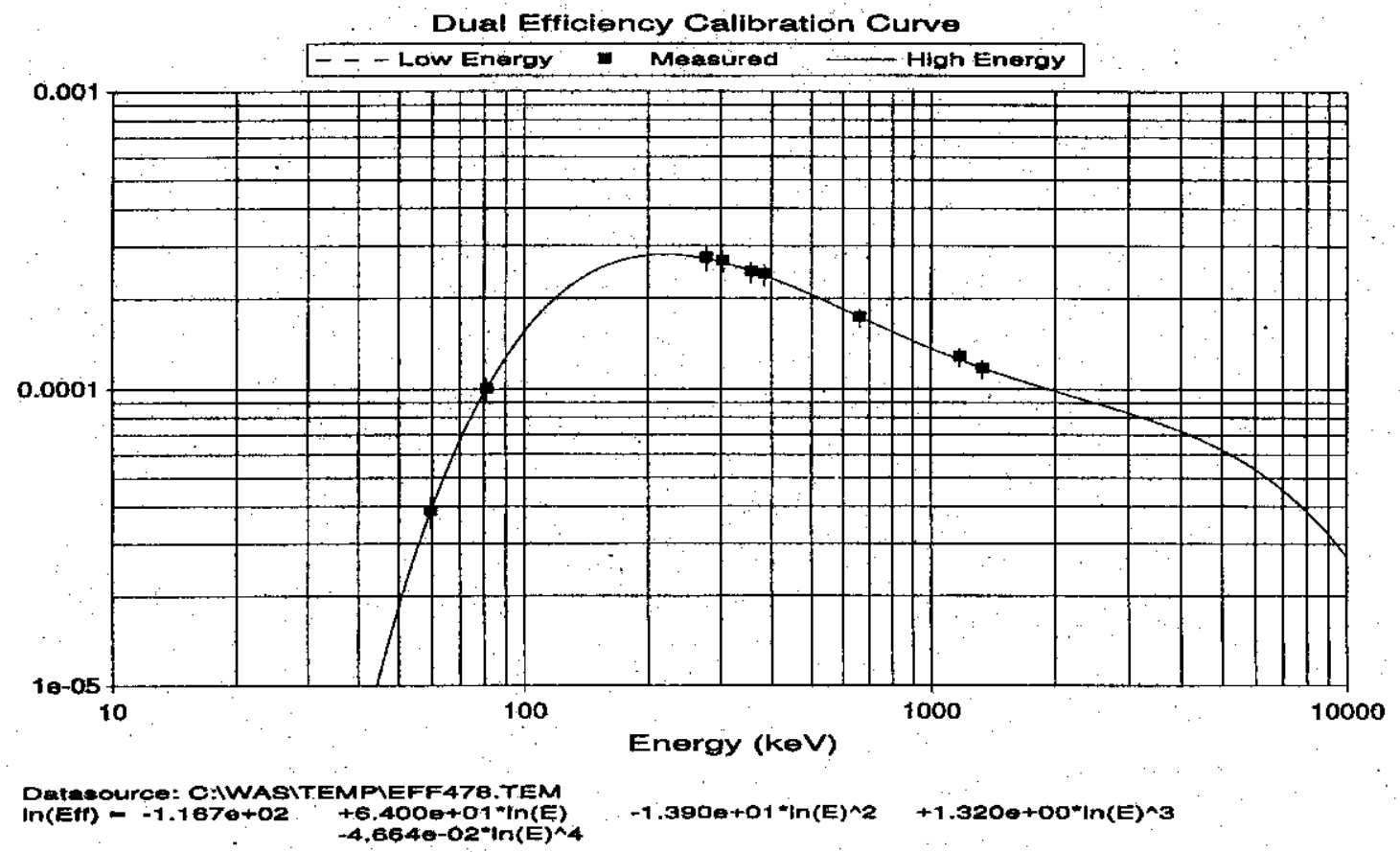

Seg 9, SEGe 2, Drum position 3. 
Homosote Drum, density $=0.43029 \mathrm{gms} / \mathrm{cc}$, No Shield (collimator). Spectrum Seq \# 3994

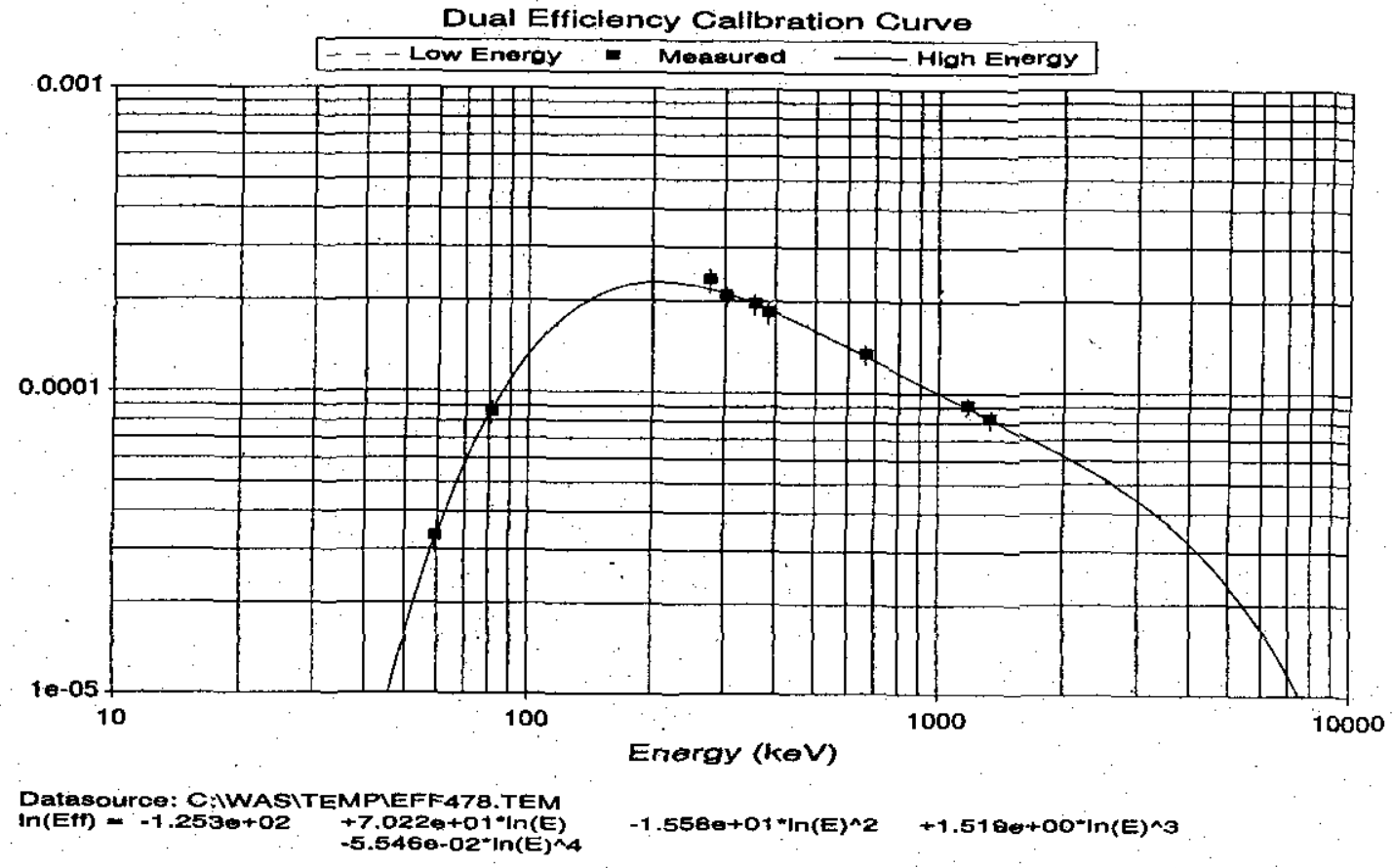

Seg 10, SEGe 1, Drum position 1.

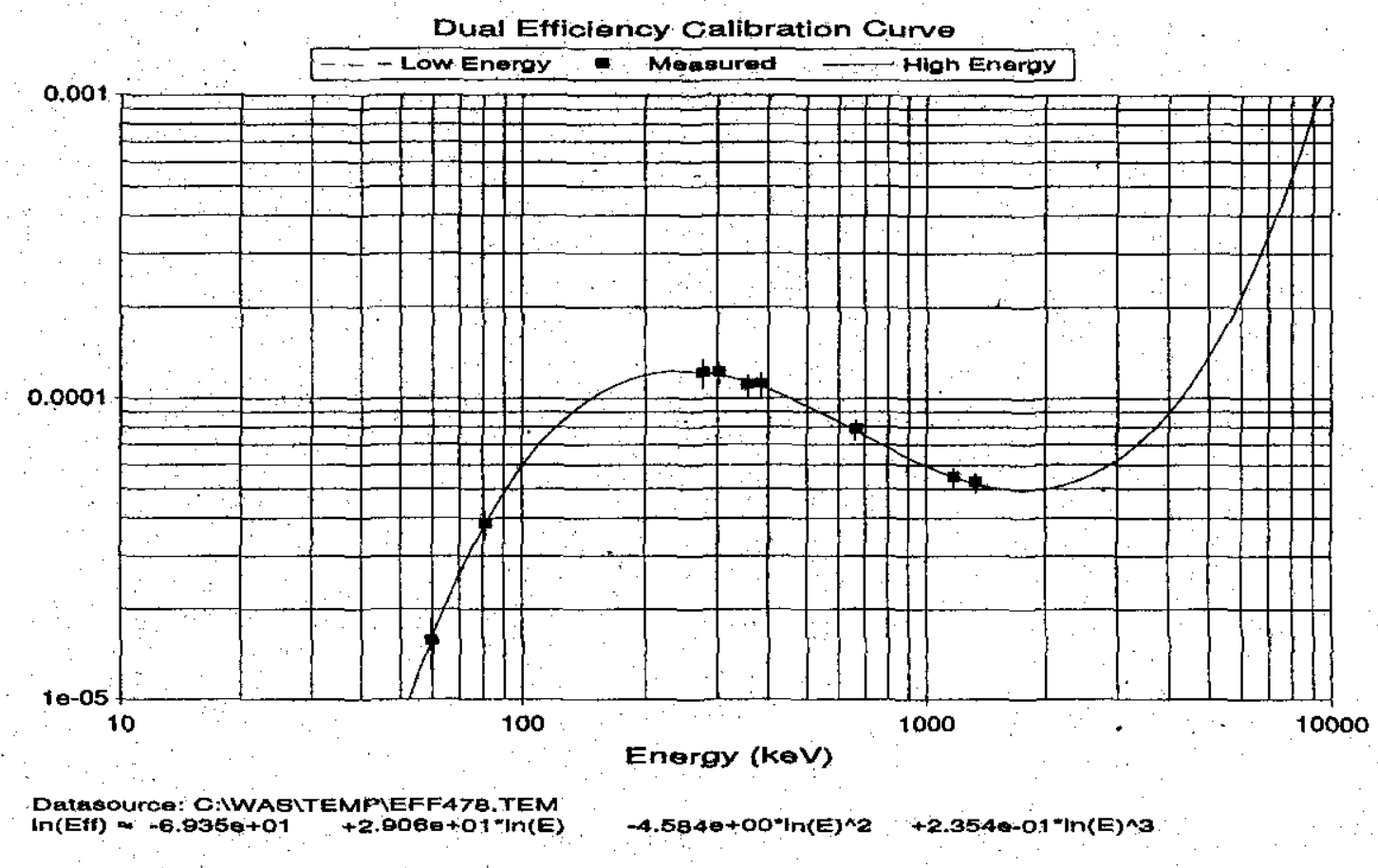

Seg 11, SEGe 1, Drum position 2. 
HNF-5 148, Rev. 2

Homosote Drum, density $=0.43029 \mathrm{gms} / \mathrm{cc}$, No Shield (collimator). Spectrum Seq \# 3994

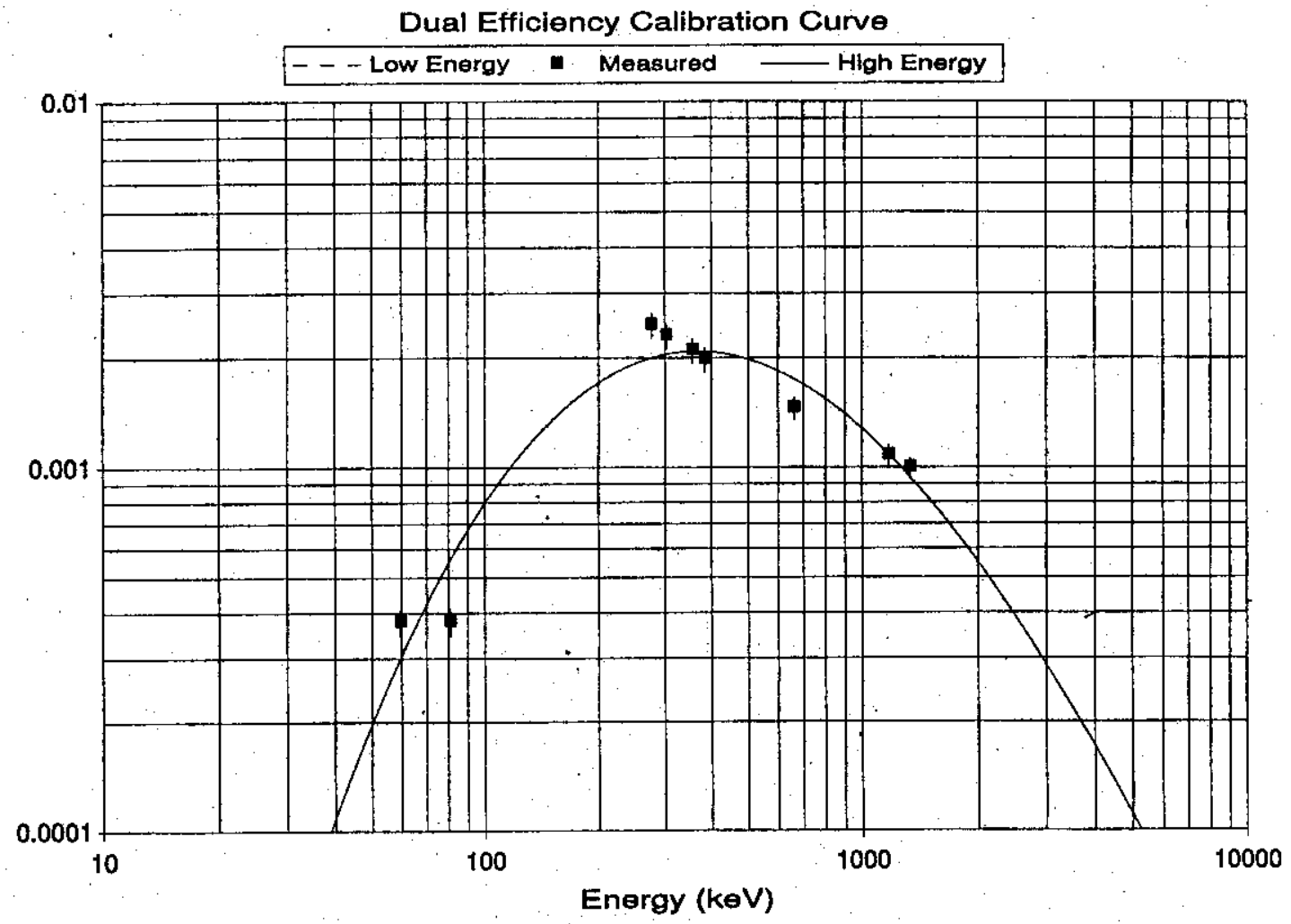

Datasource: C:IWASITEMPIEFF478.TEM $\ln (E f f)=-3: 182 \theta+01+9.945 \theta+00 " \ln (E)$

$-1.1610+00^{*} \ln (E)^{\wedge} 2+3.6010-02^{*} \ln (E)^{\wedge} 3$

Sum Segments

E-19 
HNF-5148, Rev. 2

Homosote Drum, density $=0.43029 \mathrm{gms} / \mathrm{cc}$, Shield (collimator). Spectrum Seq \# 3995

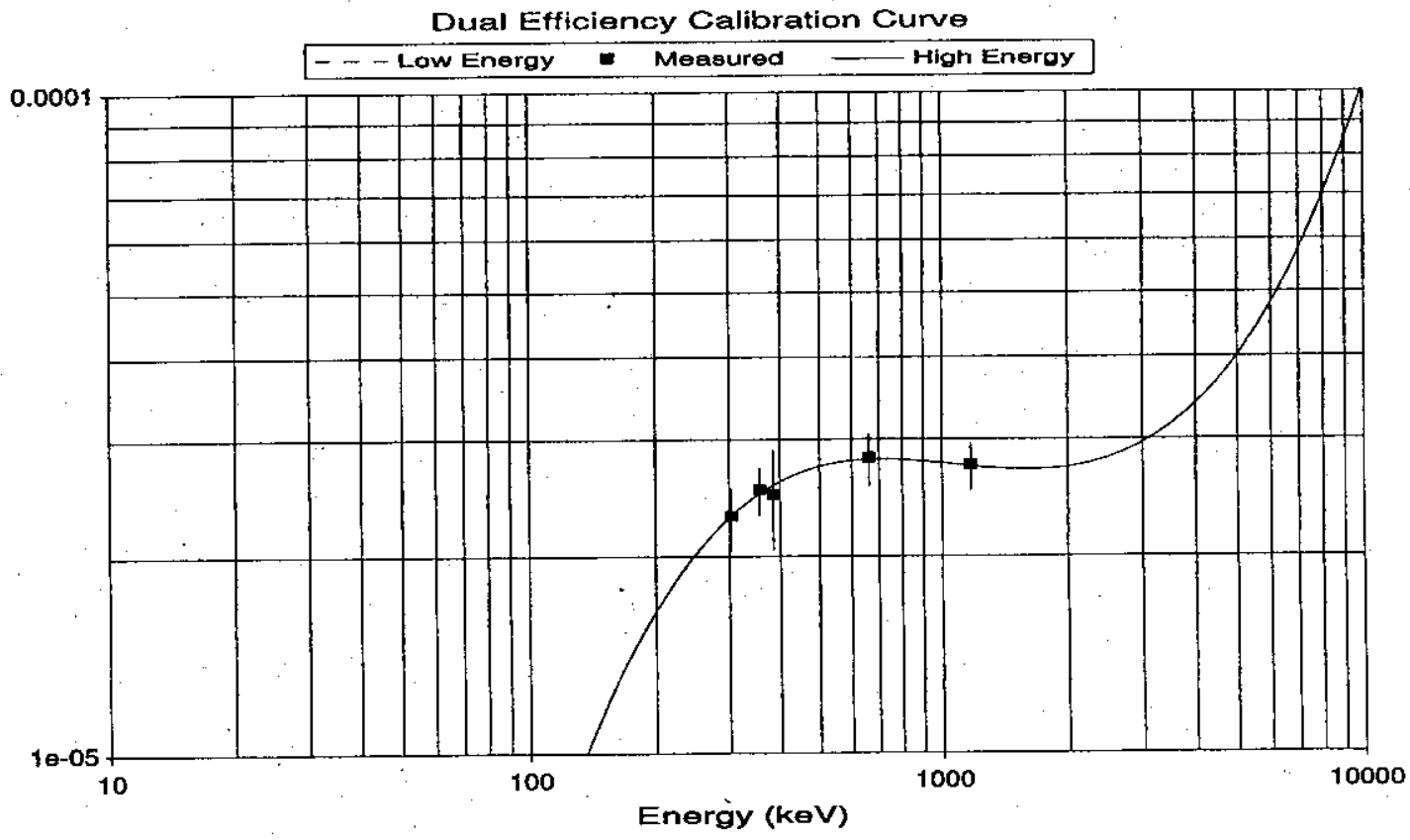

Datasource: C:IWASITEMPEFF478.TEM $\ln (E f)=-5.468 \theta+01+1.013 \theta+01 * \ln (E)$

$-2.751 \theta+00^{-} \ln (E)^{\wedge} 2+1.3148-01^{*} \ln (E)^{\wedge} 3$

Seg 2, SEGe 4, Drum position 2,

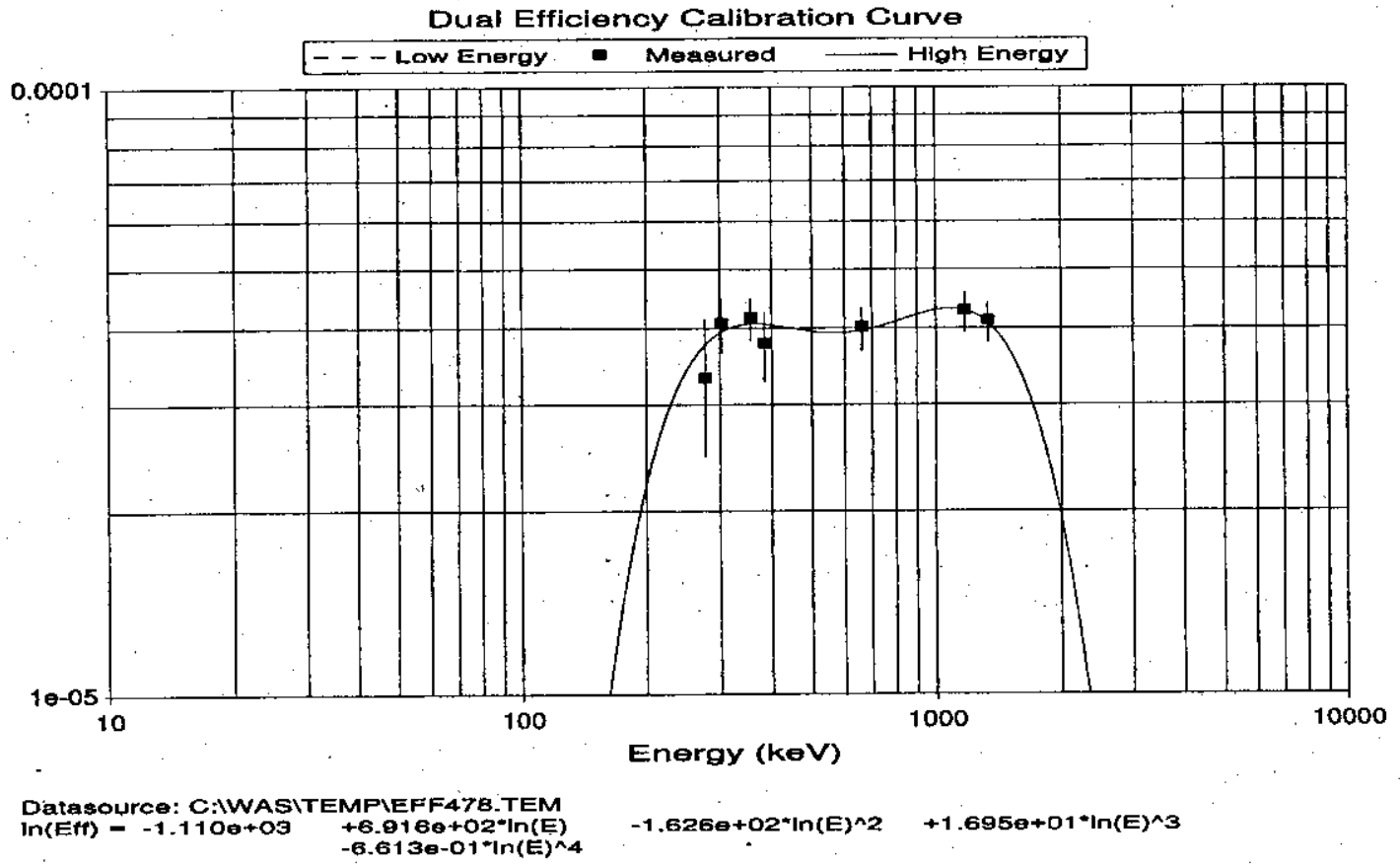

Seg 3, SEGe 4, Drum position 3 
Homosote Drum, density $=0.43029 \mathrm{gms} / \mathrm{cc}$, Shield (collimator). Spectrum Seq \# 3995

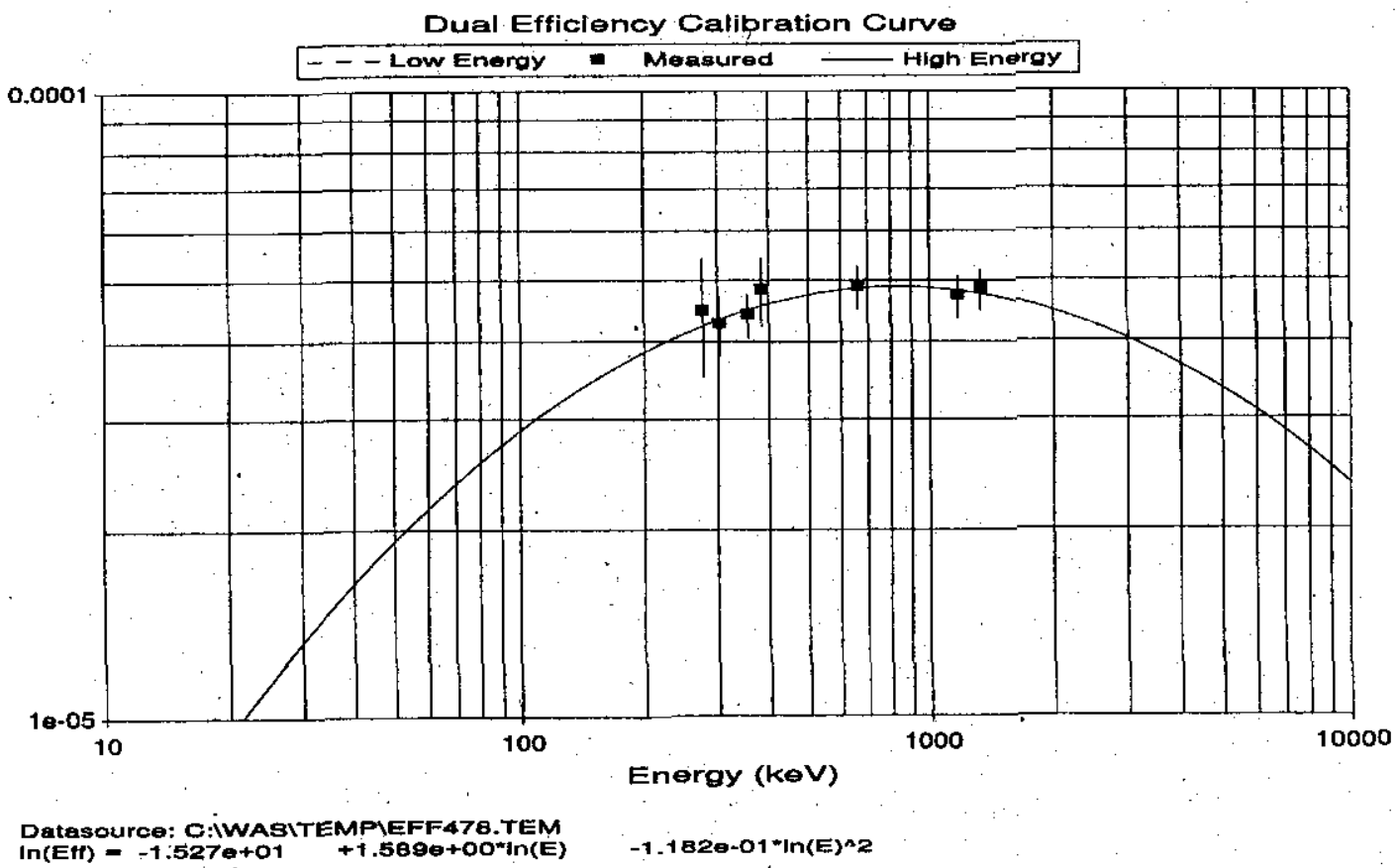

Seg 4, SEGe 3, Drum position 1.

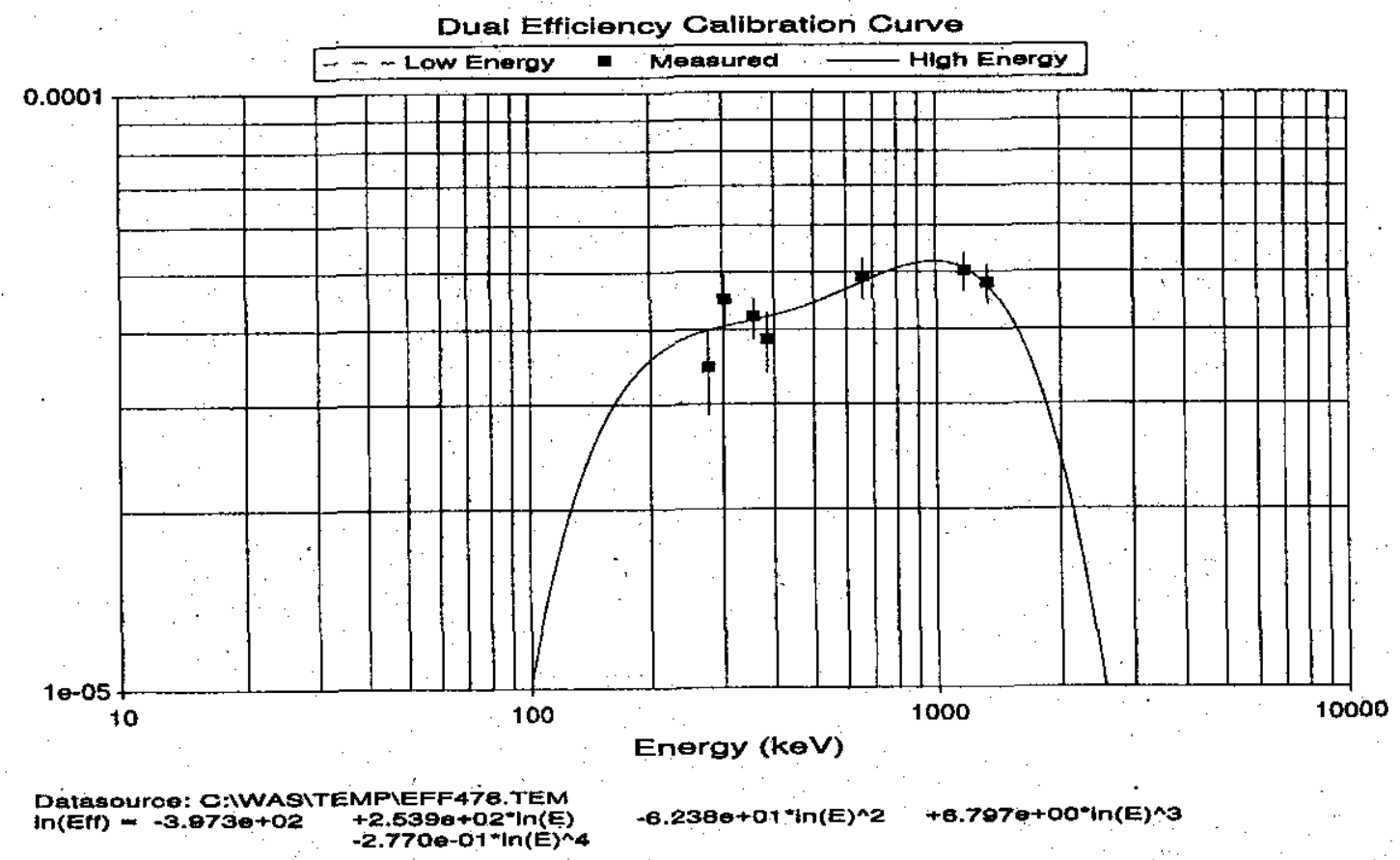

Seg 5, SEGe 3, Drum position 2. 
Homosote Drum, density $=0.43029 \mathrm{gms} / \mathrm{cc}$, Shield (collimator). Spectrum Seq \# 3995

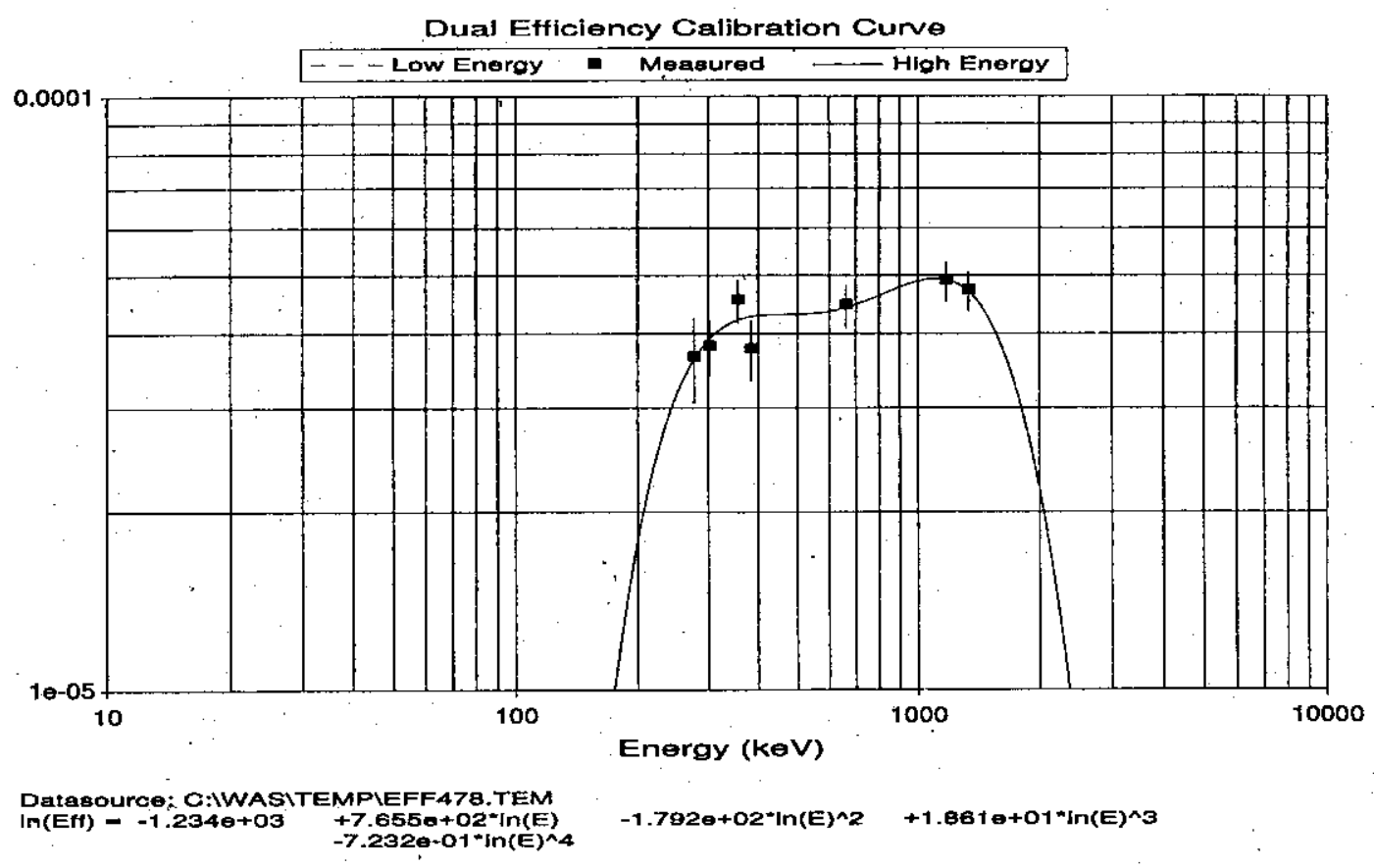

Seg 6, SEGe 3, Drum position 3.

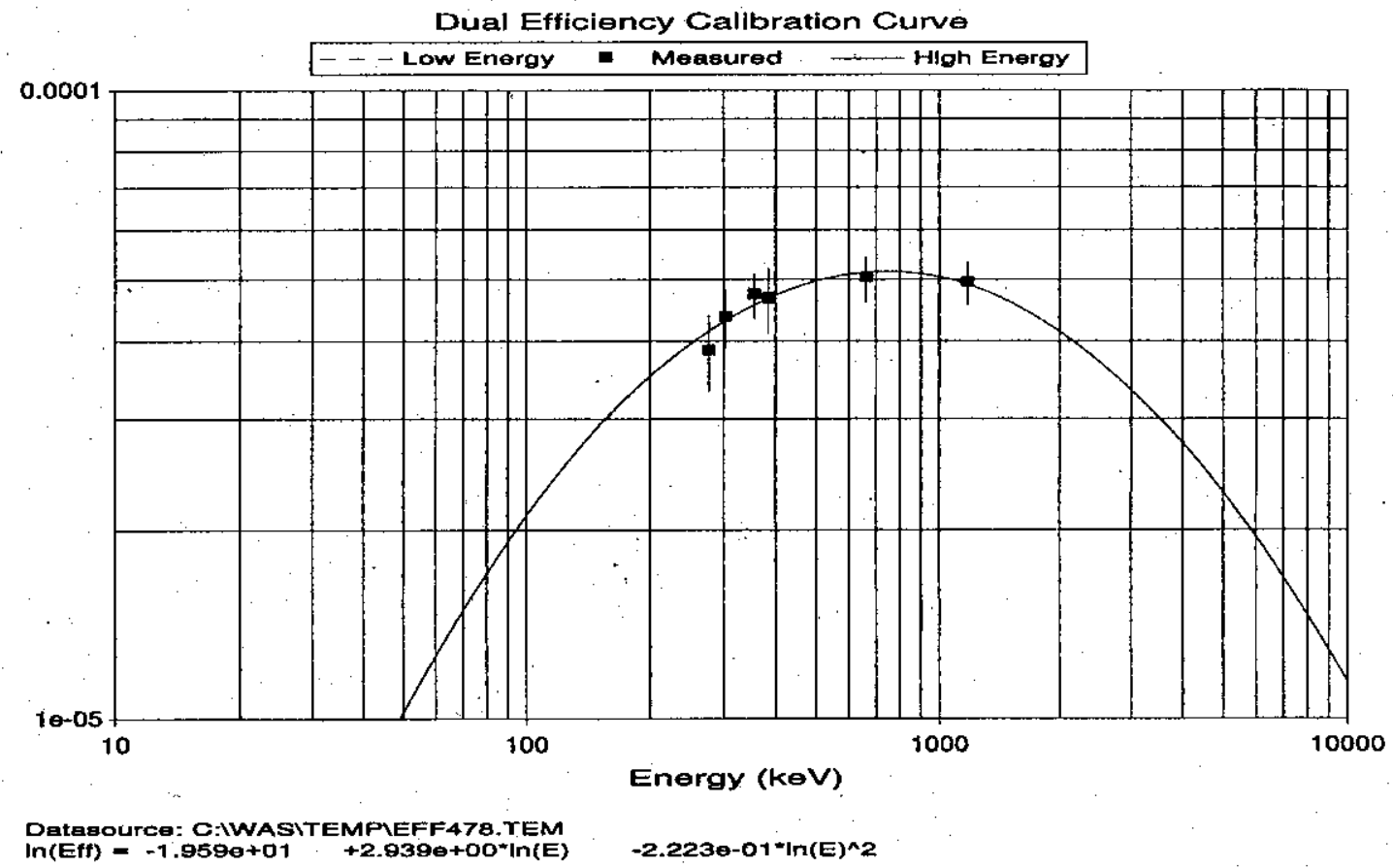

Seg 7, SEGe 2, Drum position 1. 
HNF-5148, Rev. 2

Homosote Drum, density $=0.43029$ gms $/$ cc, Shield (collimator). Spectrum Seq \# 3995

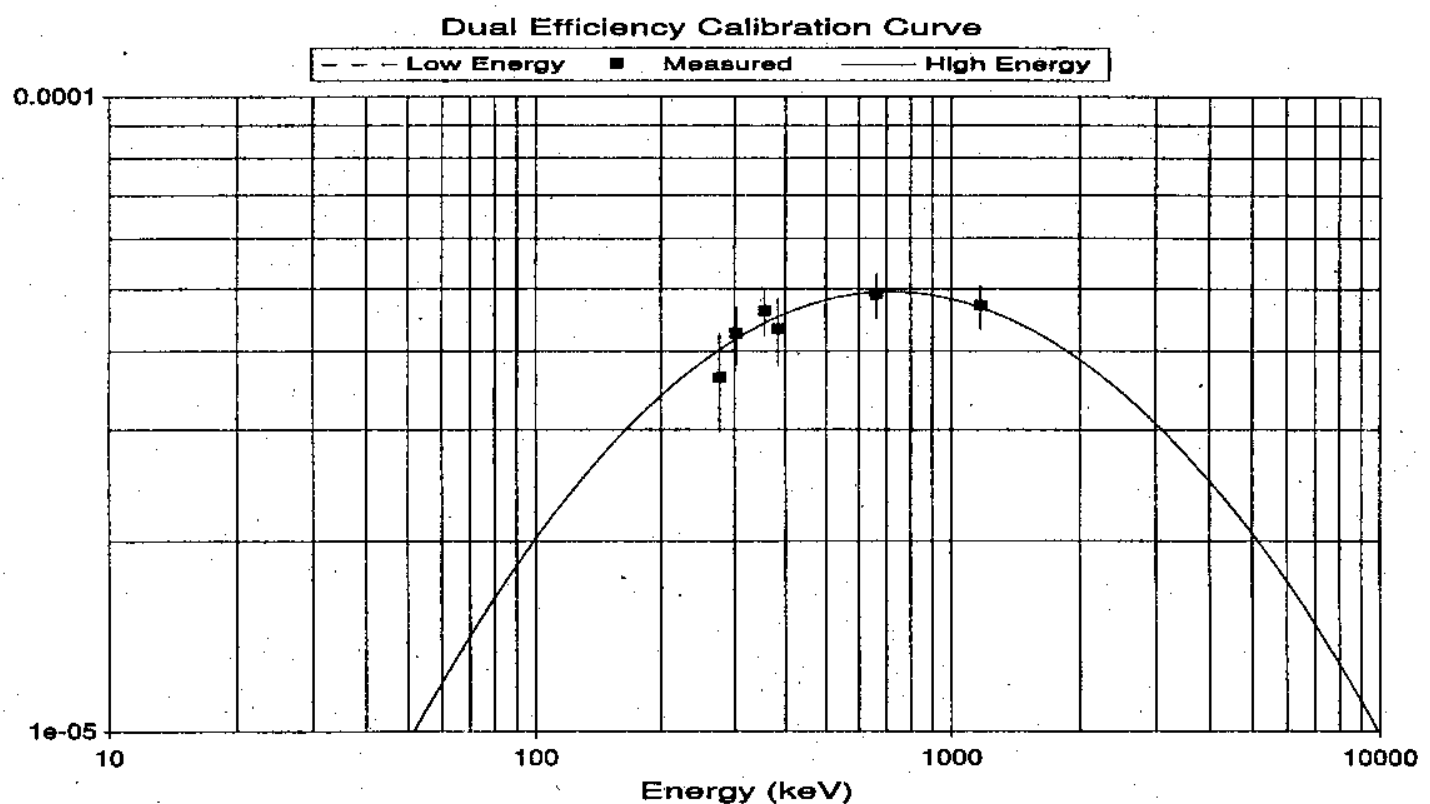

DETGSOUTE: ONWASITEMPIEFFA78.TEM $\ln \left(\right.$ Etf) - -1.993e+01 $+3.0470+00^{\circ} \ln (E)$

$-2.318 \theta-01 * \ln (E)^{\wedge} 2$

Seg 8, SEGe 2, Drum position 2.

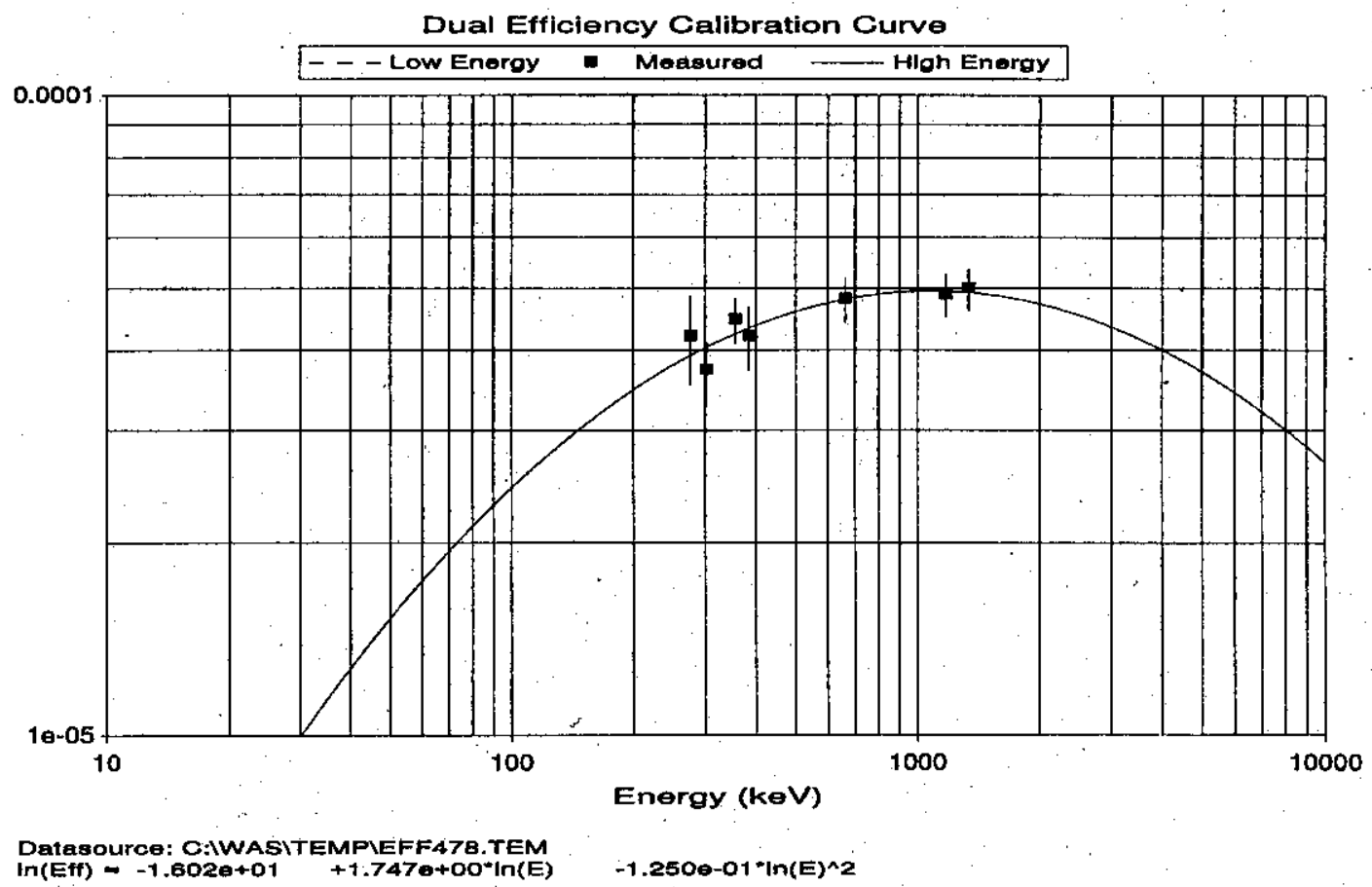

Seg 9, SEGe 2, Drum position 3. 
HNF-5148, Rev. 2

Homosote Drum, density $=0.43029 \mathrm{gms} / \mathrm{cc}$, Shield (collimator). Spectrum Seq \# 3995

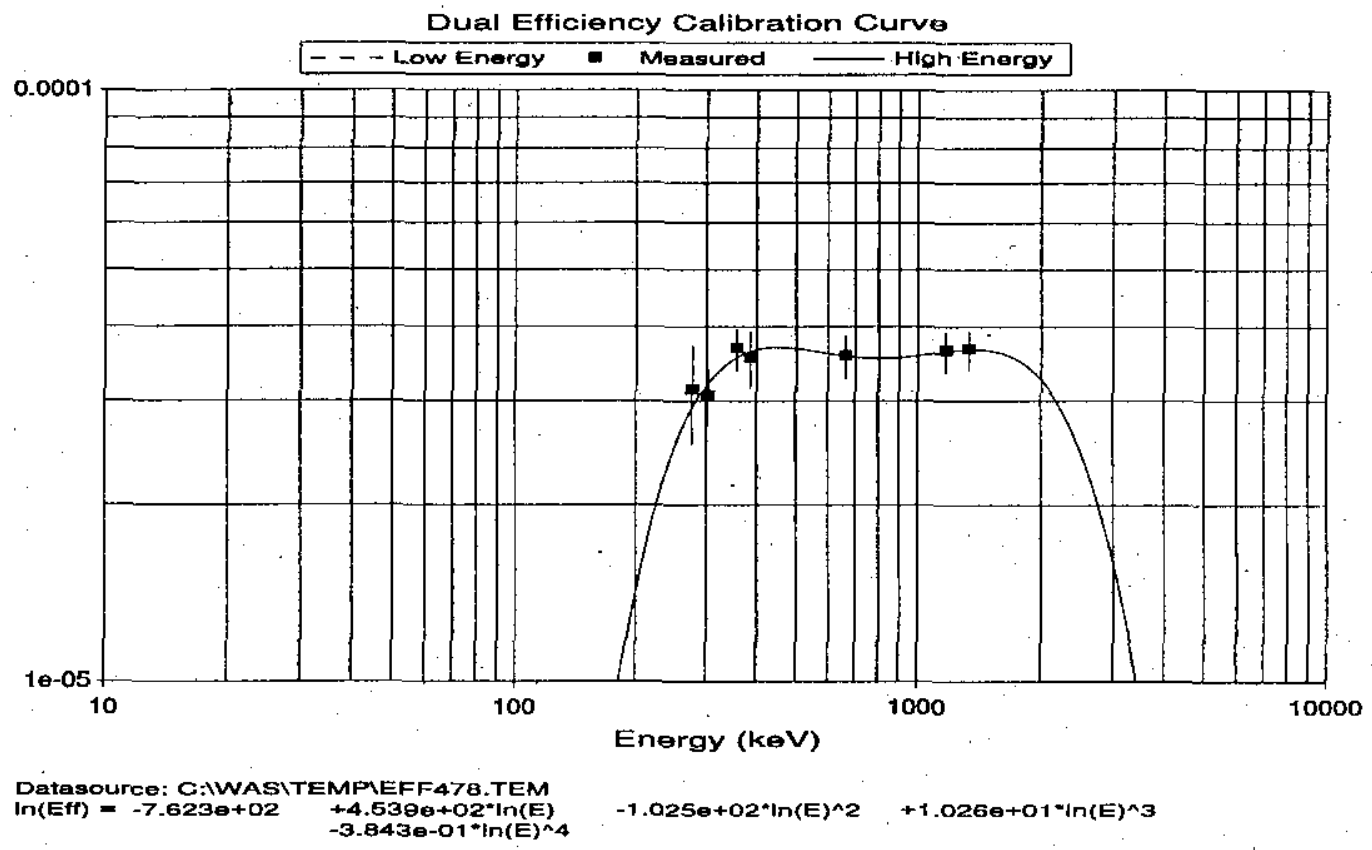

Seg 10, SEGe 1, Drum position 1.

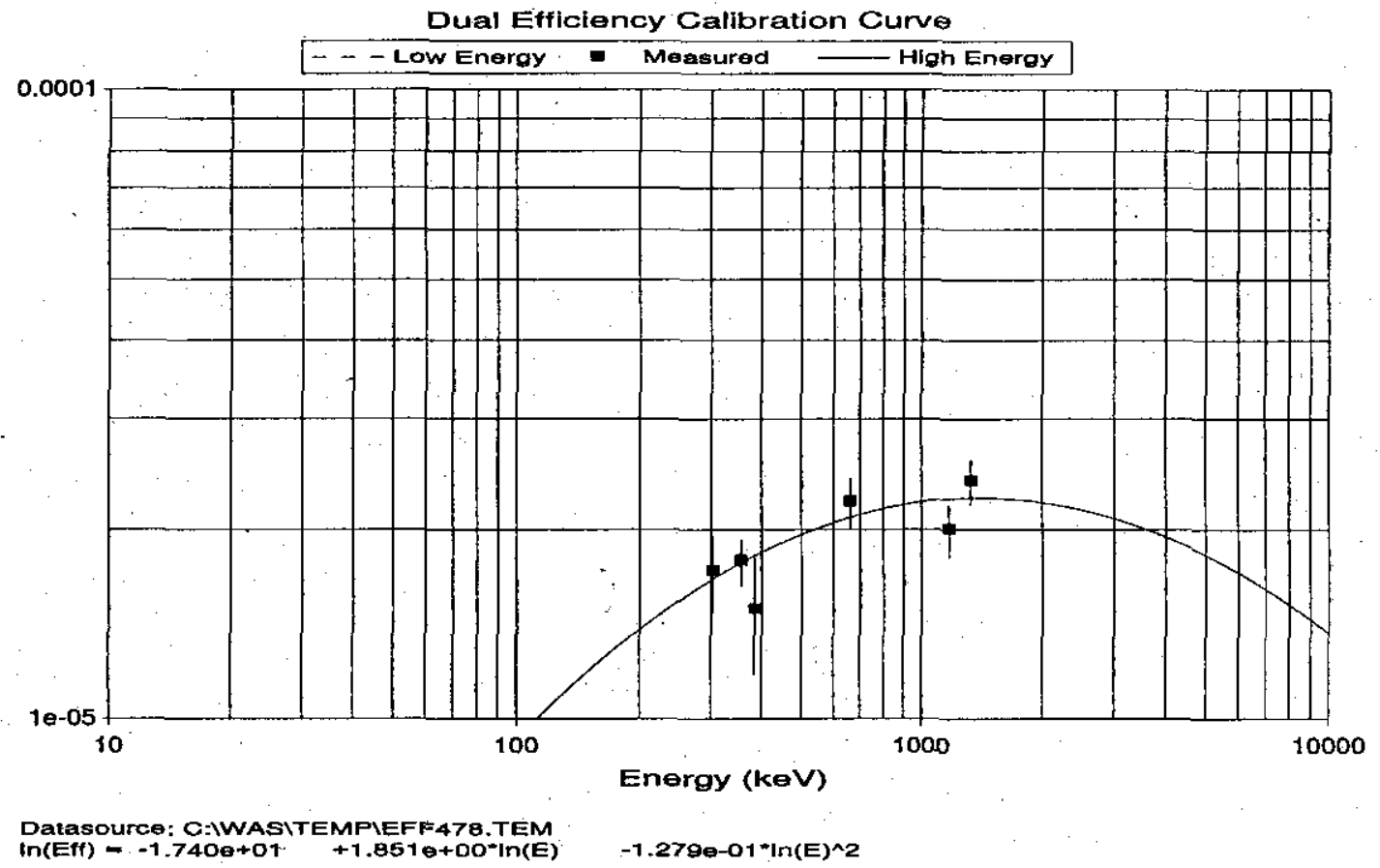

Seg 11, SEGe 1, Drum position 2. 
HNF-5148, Rev. 2

Homosote Drum, density $=0.43029 \mathrm{gms} / \mathrm{cc}$, Shield (collimator). Spectrum Seq \# 3995

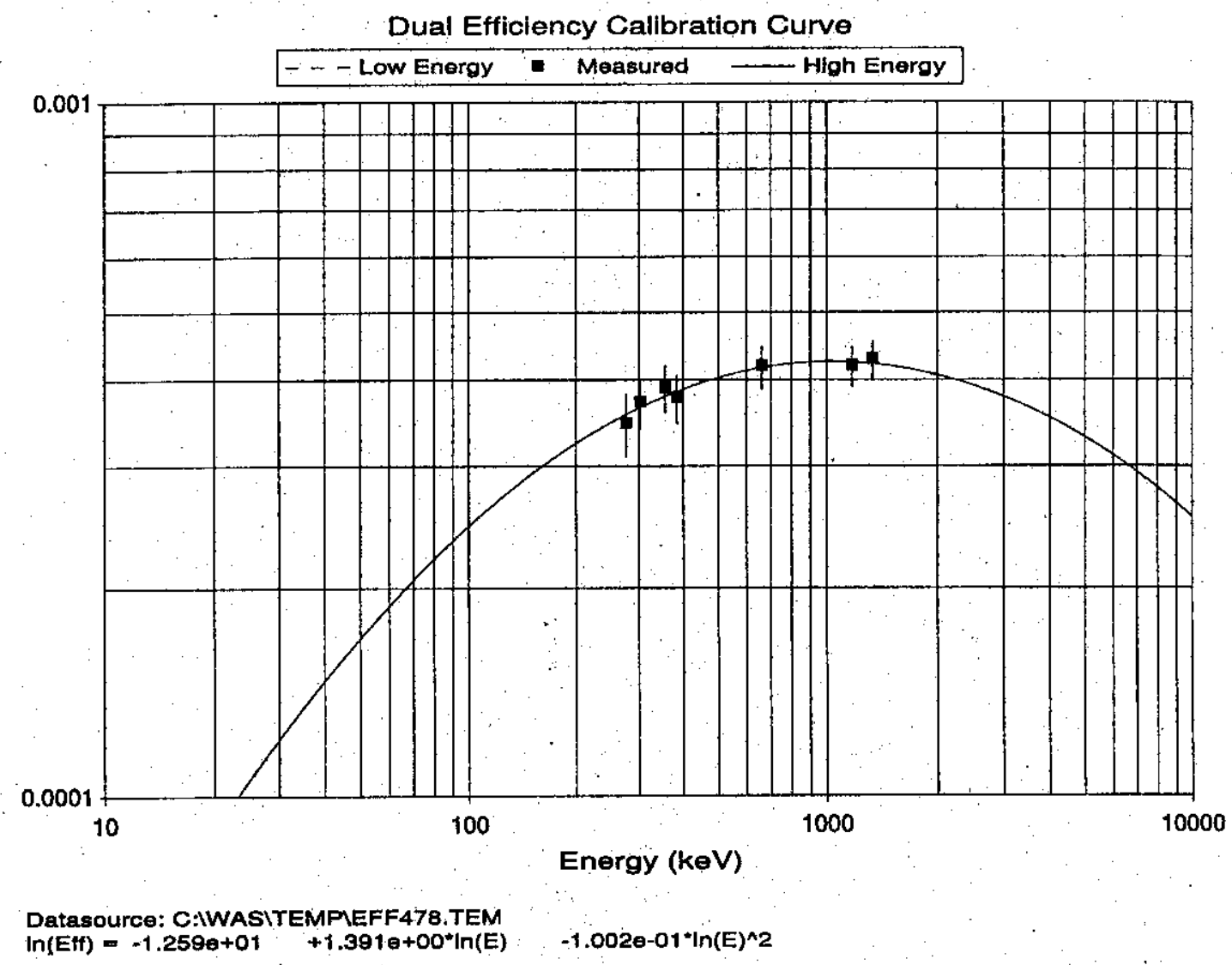

Sum Segments. 
HNF-5148, Rev. 2

Particle Board Drum, density $=0.65625$ gms $/ \mathrm{cc}$, No Shield (collimator). Spectrum Seq \# 3992

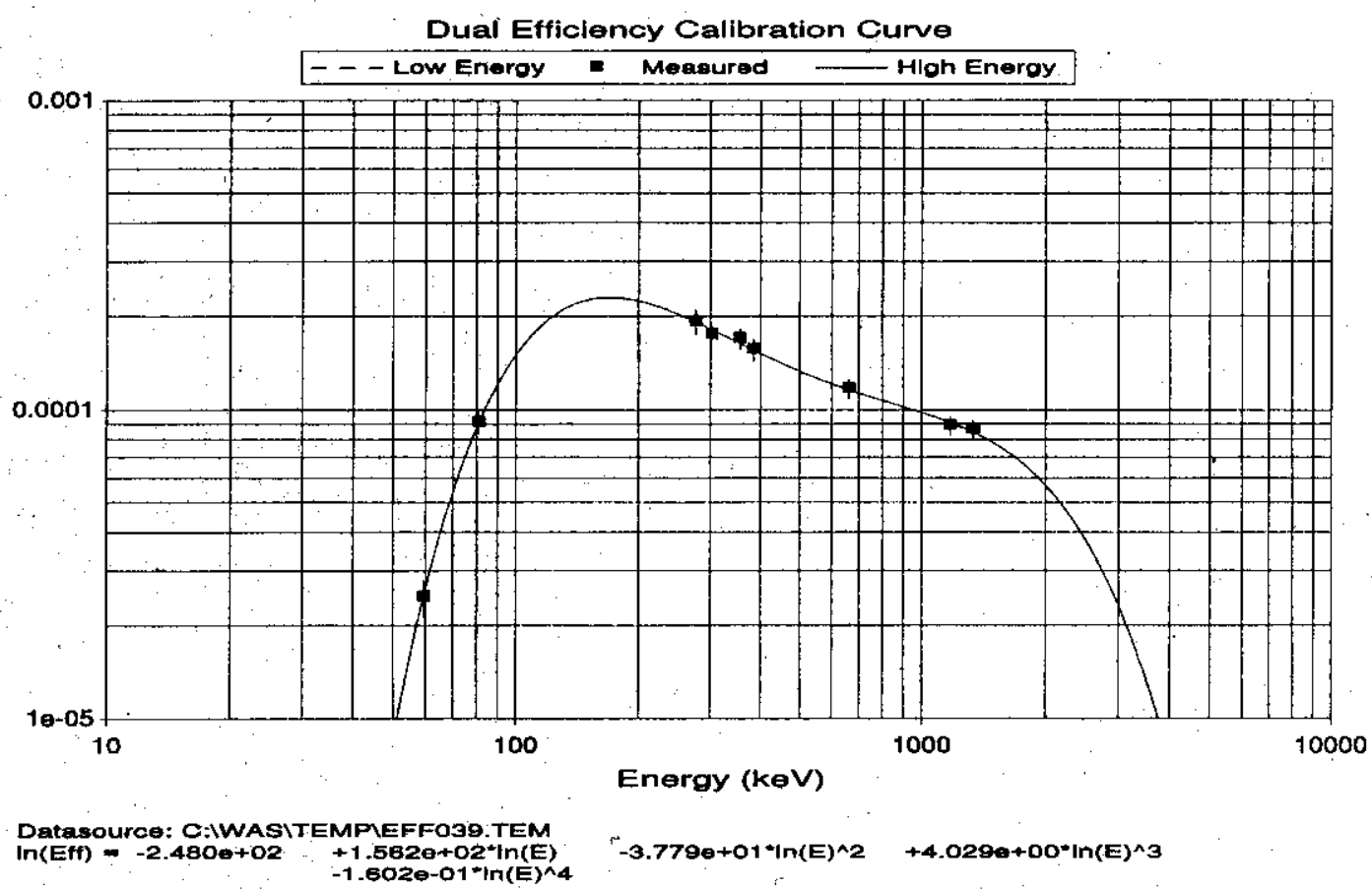

Seg 2, SEGe 4, Drum position 2.

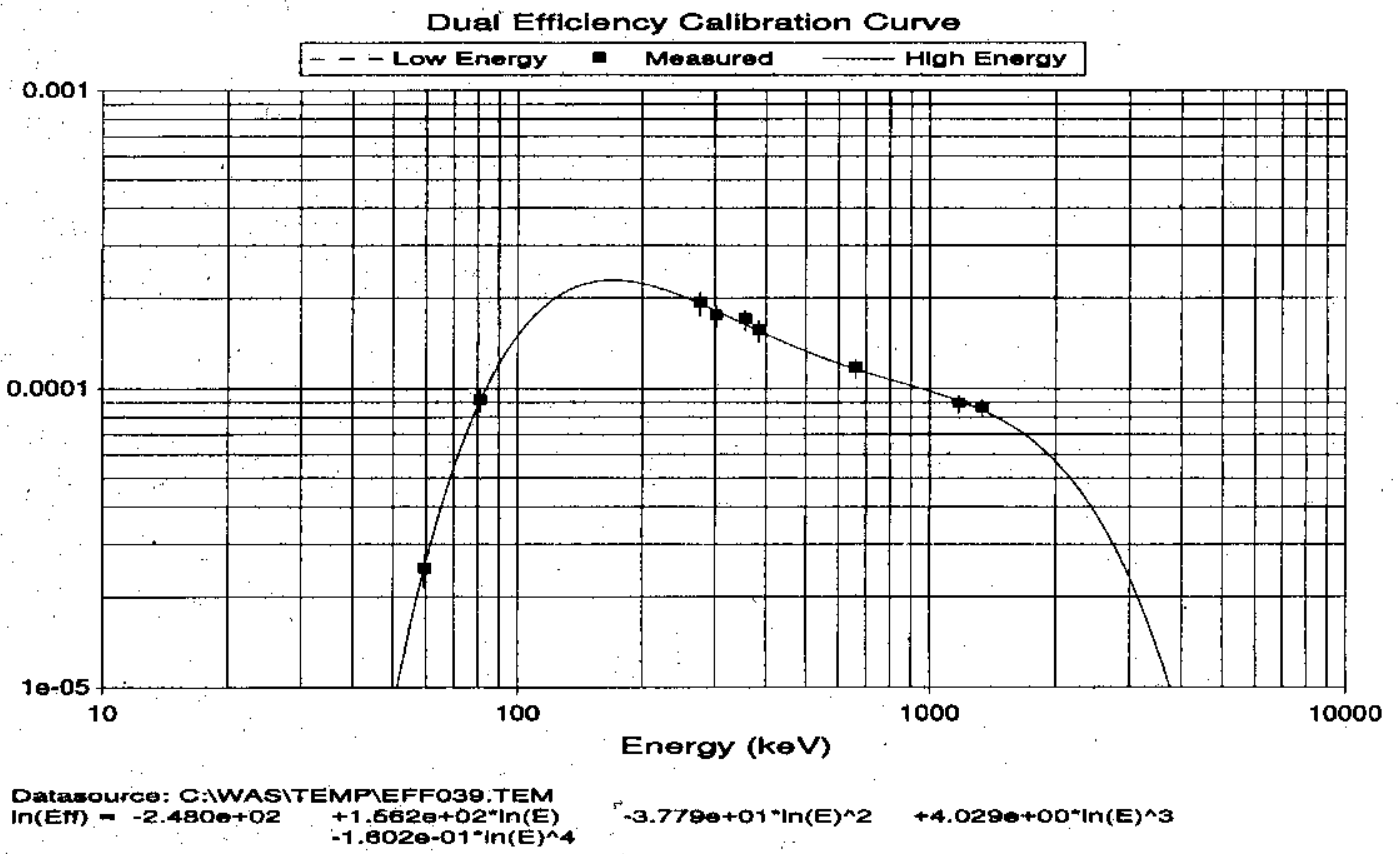

Seg 3, SEGe 4, Drum position 3. 
HNF-5148, Rev. 2

Particle Board Drum, density $=0.65625 \mathrm{gms} / \mathrm{cc}$, No Shield (collimator). Spectrum Seq \# 3992

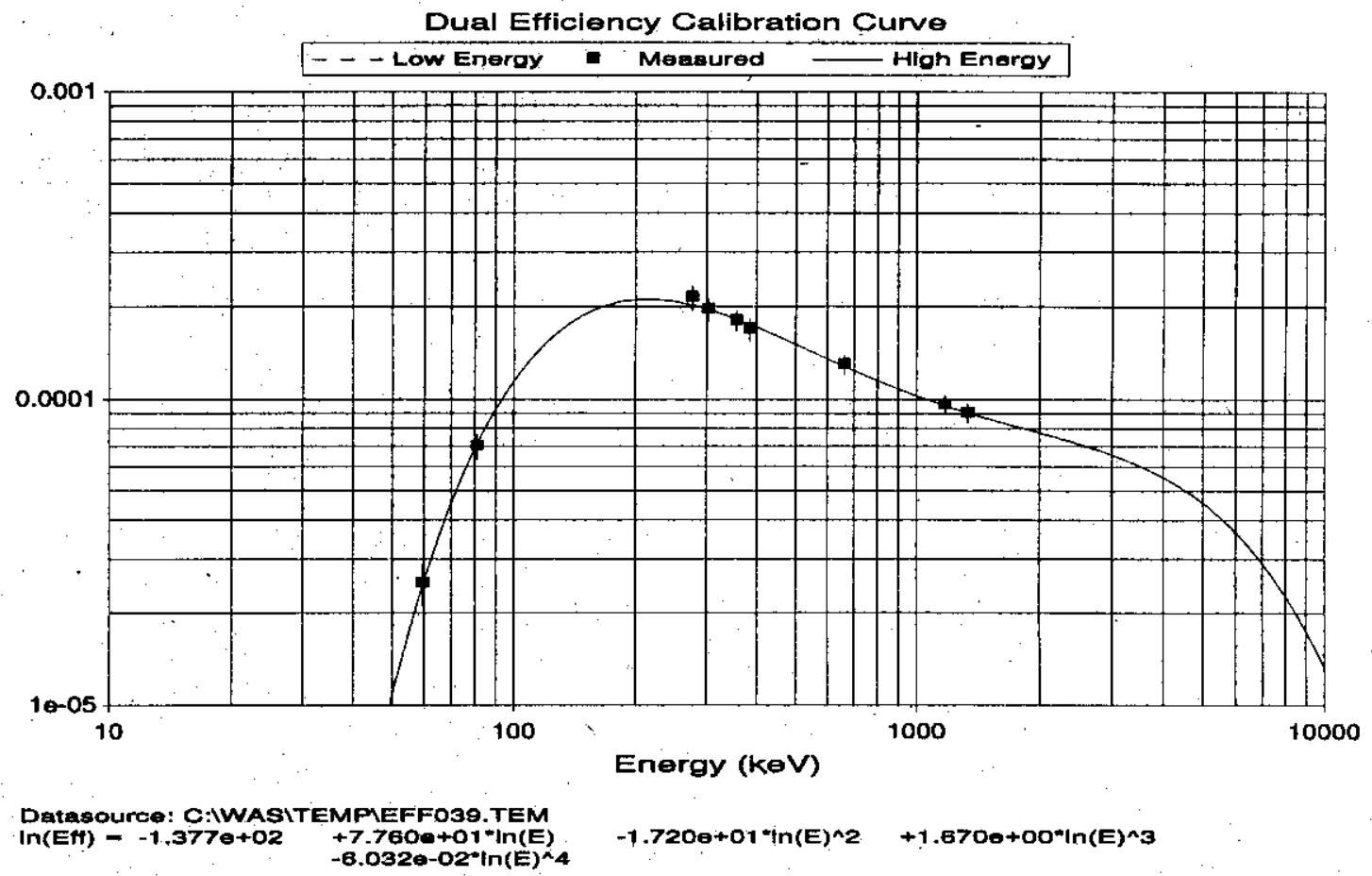

Seg 4, SEGe 3, Drum position 1.

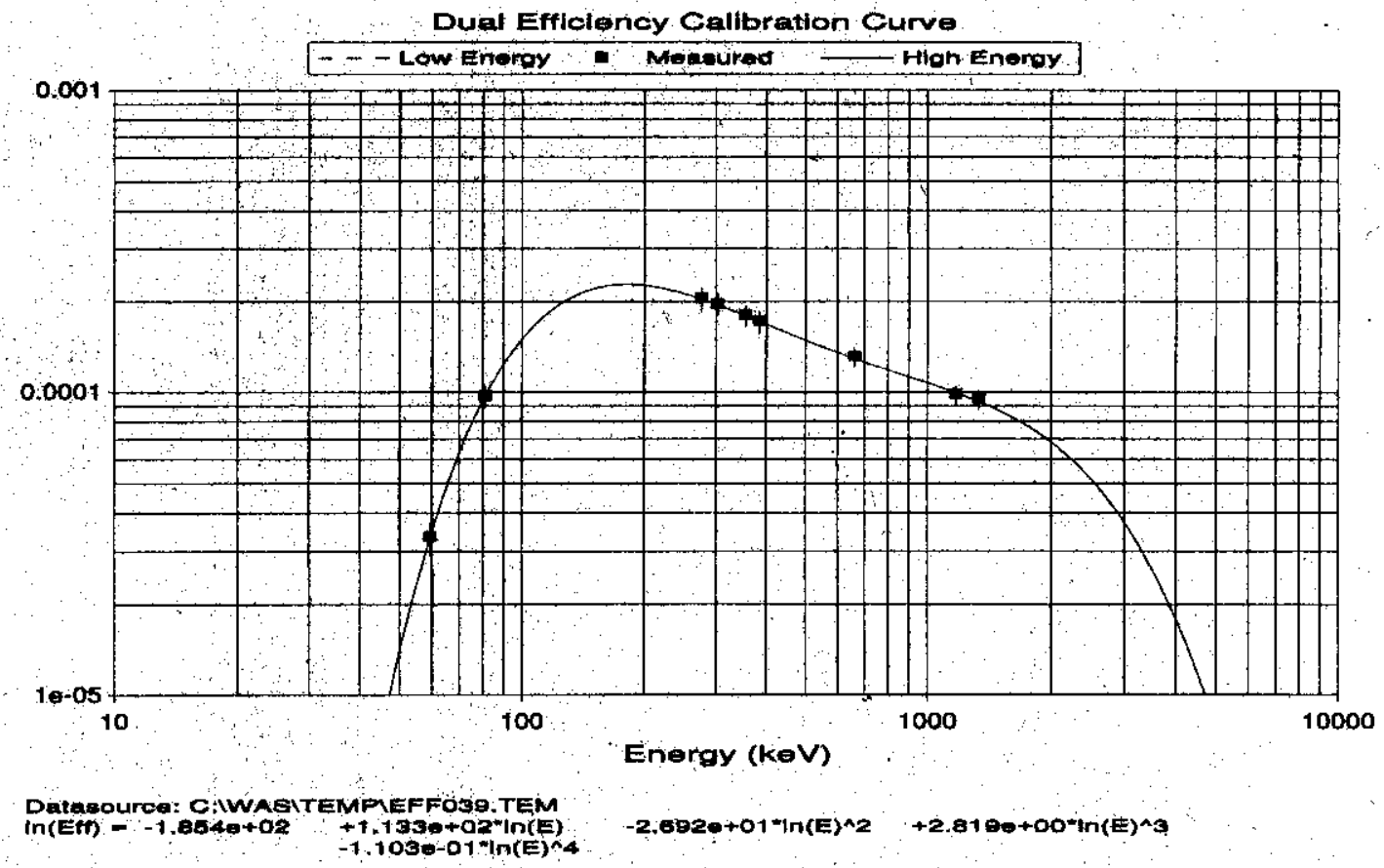

Seg 5, SEGe 3, Drum position 2. 
HNF-5148, Rev. 2

Particle Board Drum, density $=0.65625 \mathrm{gms} / \mathrm{cc}$, No Shield (collimator). Spectrum Seq \# 3992

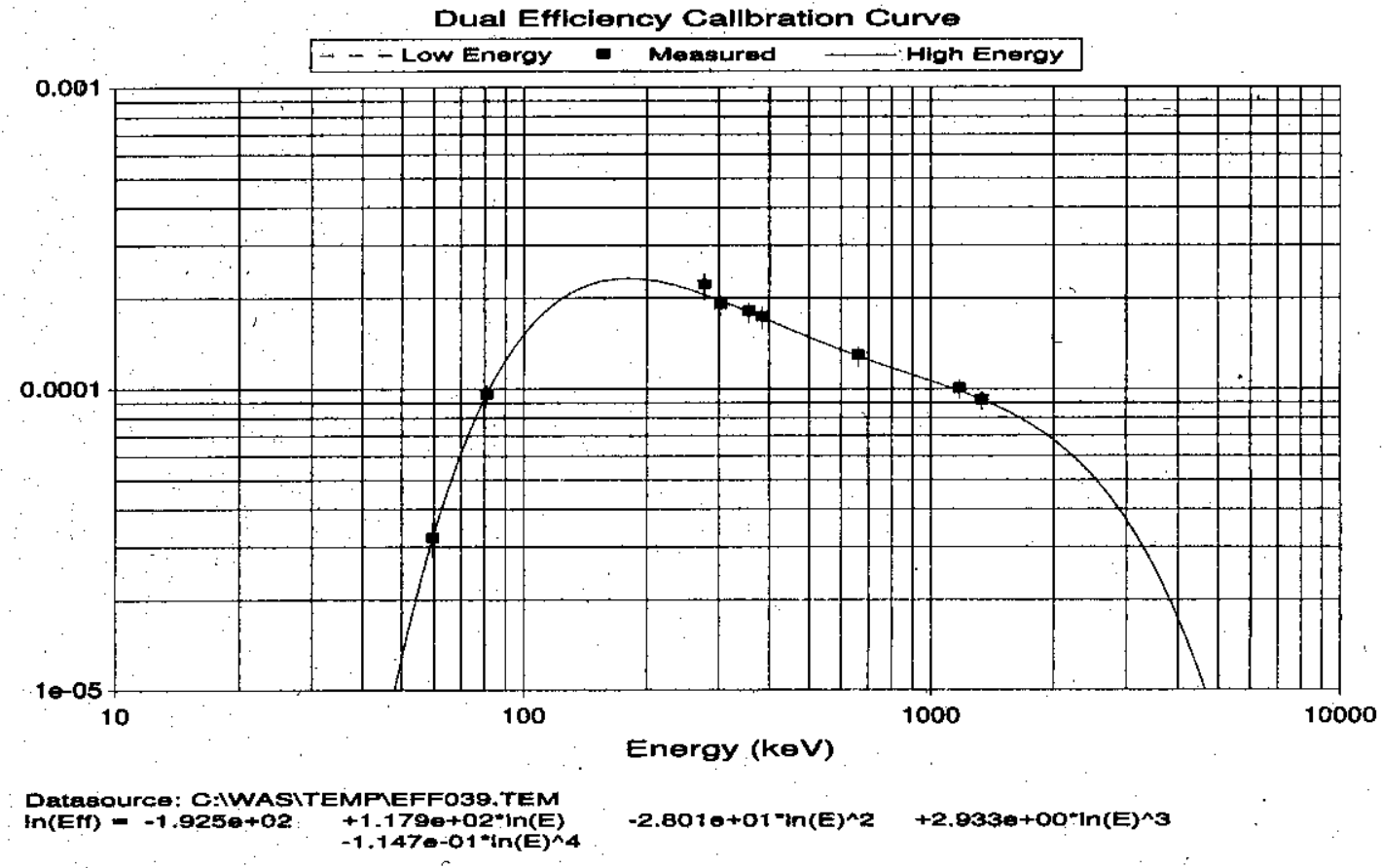

Seg 6, SEGe 3, Drum position 3.

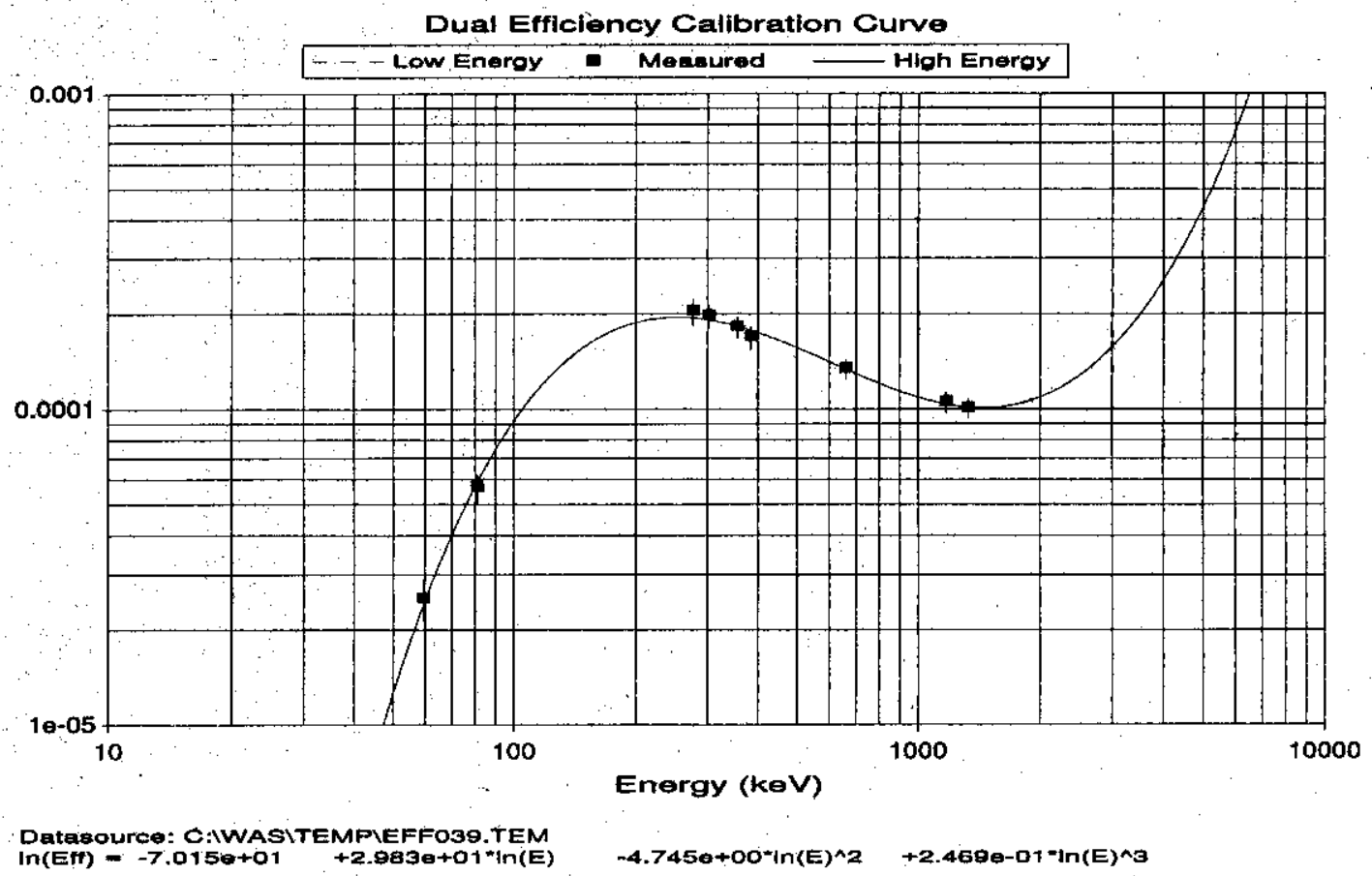

Seg 7, SEGe 2, Drum position 1. 
Particle Board Drum, density $=0.65625$ gms $/ \mathrm{cc}$, No Shield (collimator). Spectrum Seq \# 3992

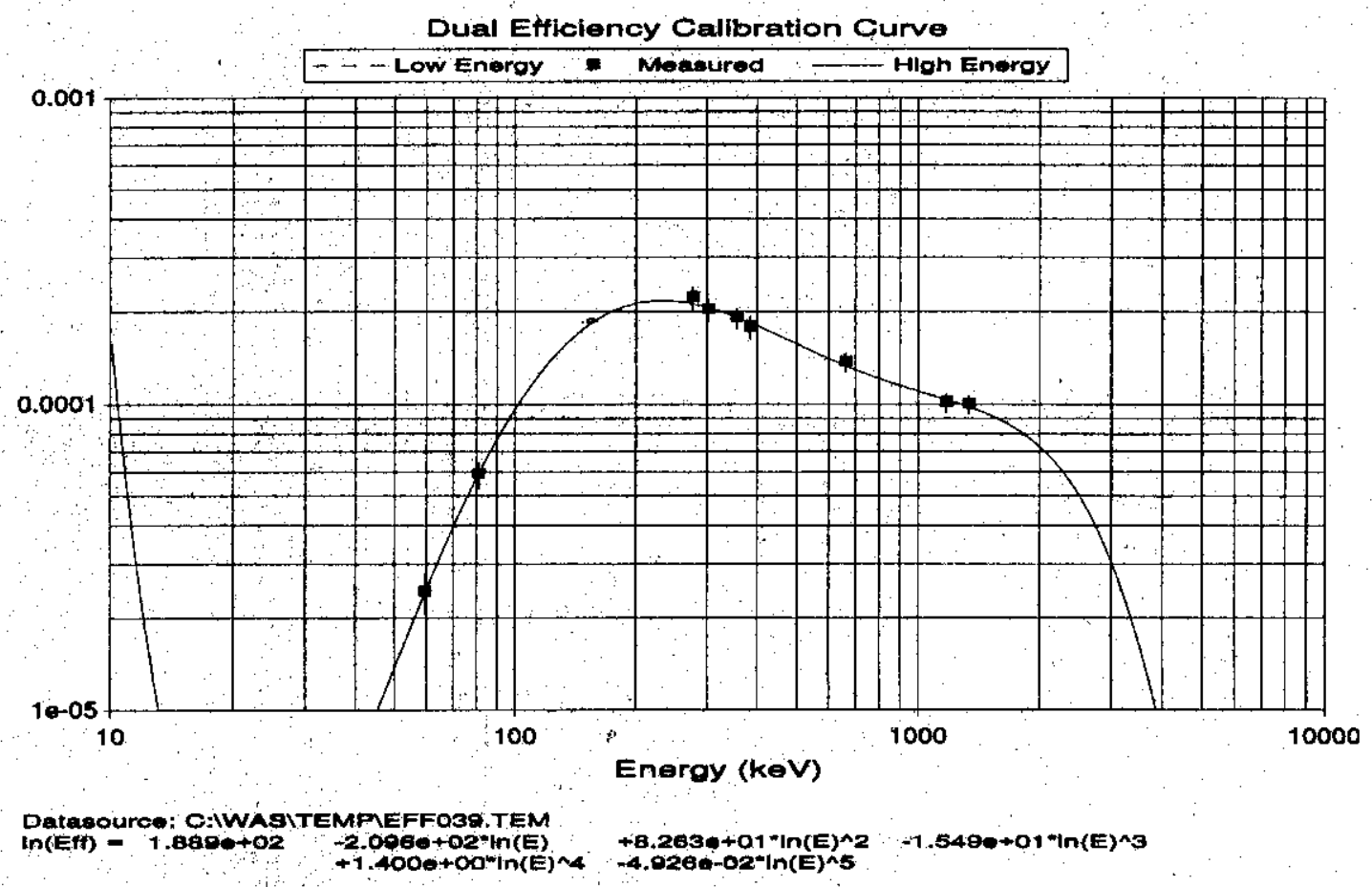

Seg 8 , SEGe 2, Drum position 2.

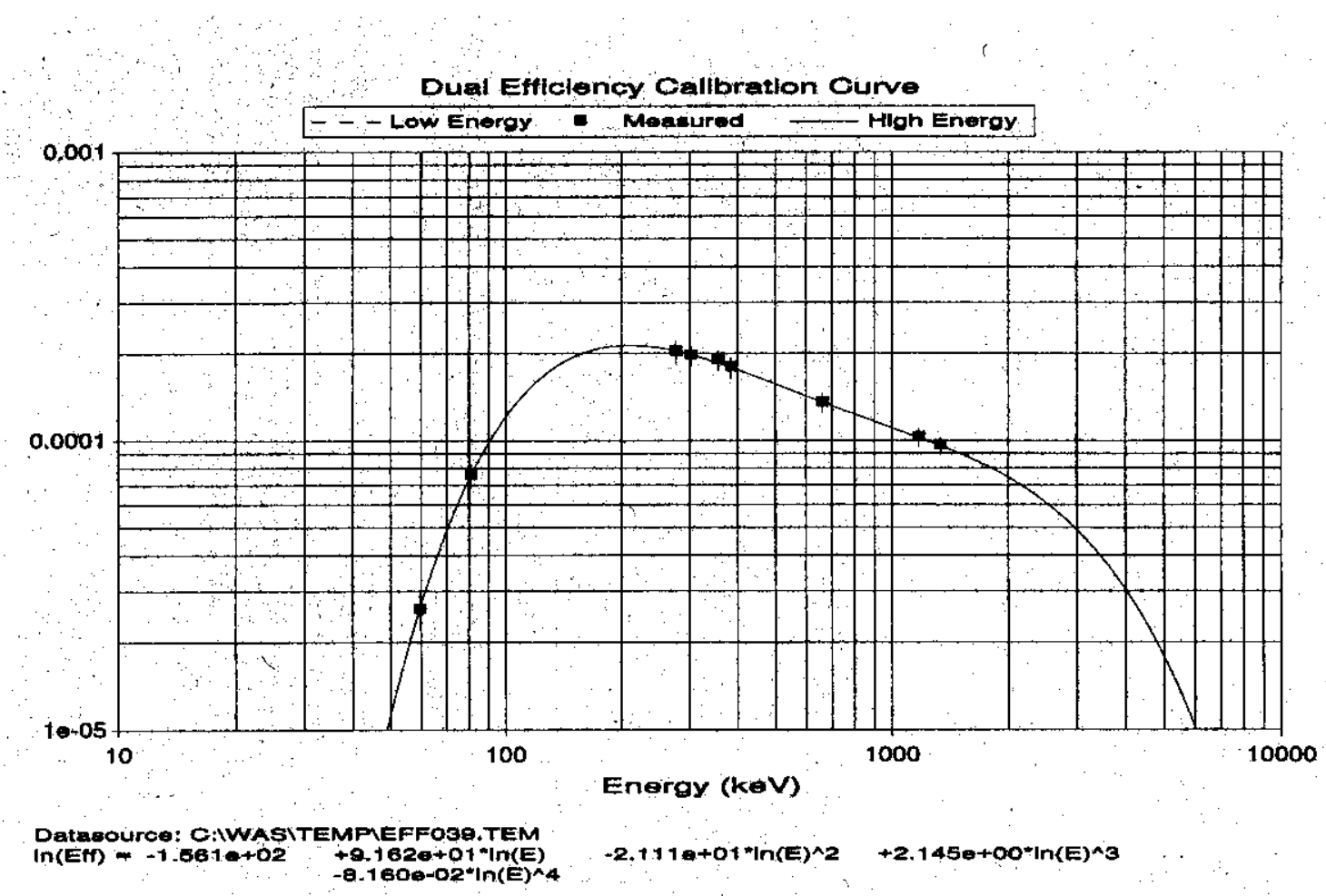

Seg 9, SEGe 2, Drum position 3. 
HNF-5148, Rev. 2

Particle Board Drum, density $=0.65625 \mathrm{gms} / \mathrm{cc}$, No Shield (collimator). Spectrum Seq \# 3992

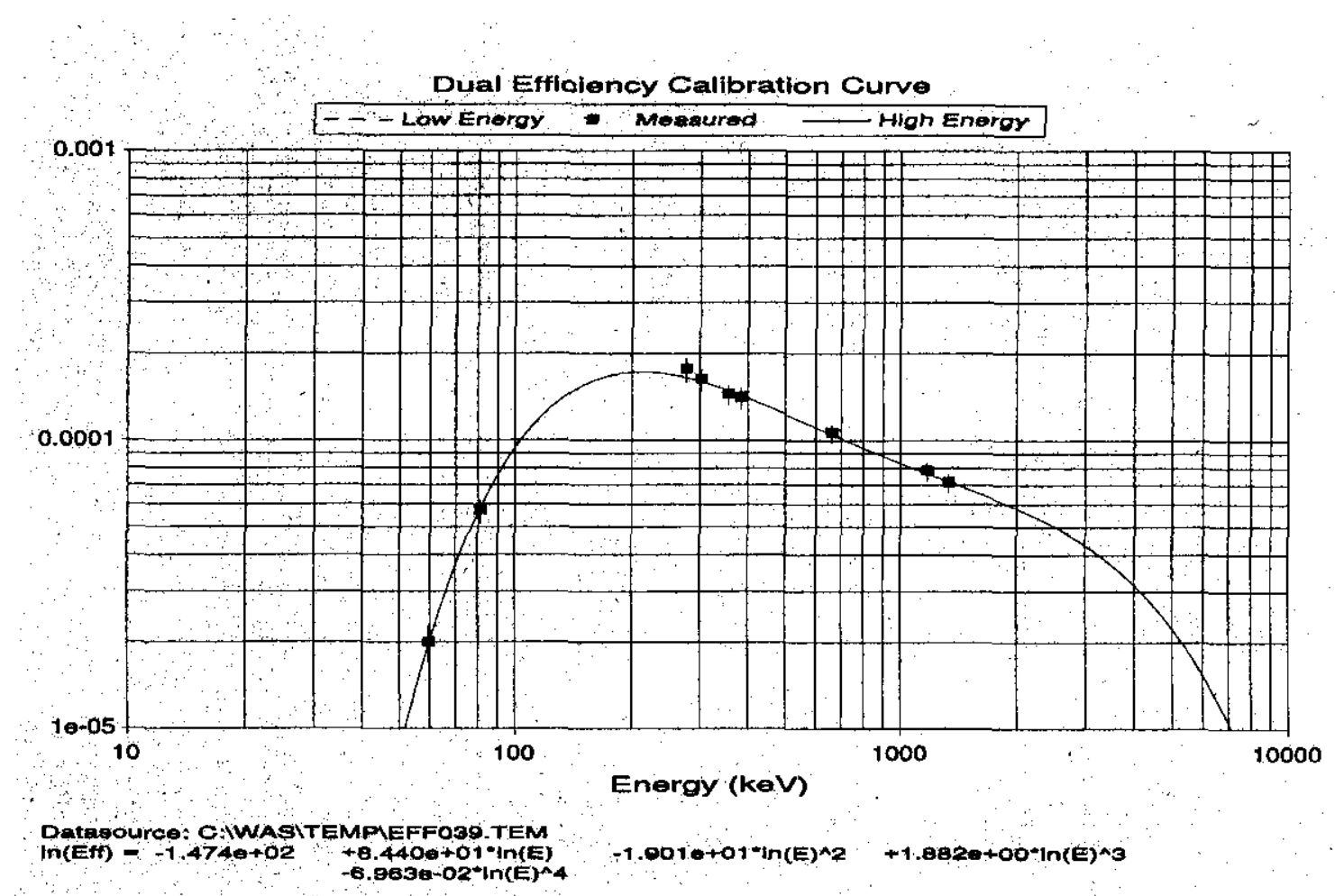

Seg 10, SEGe 1, Drum position 1.

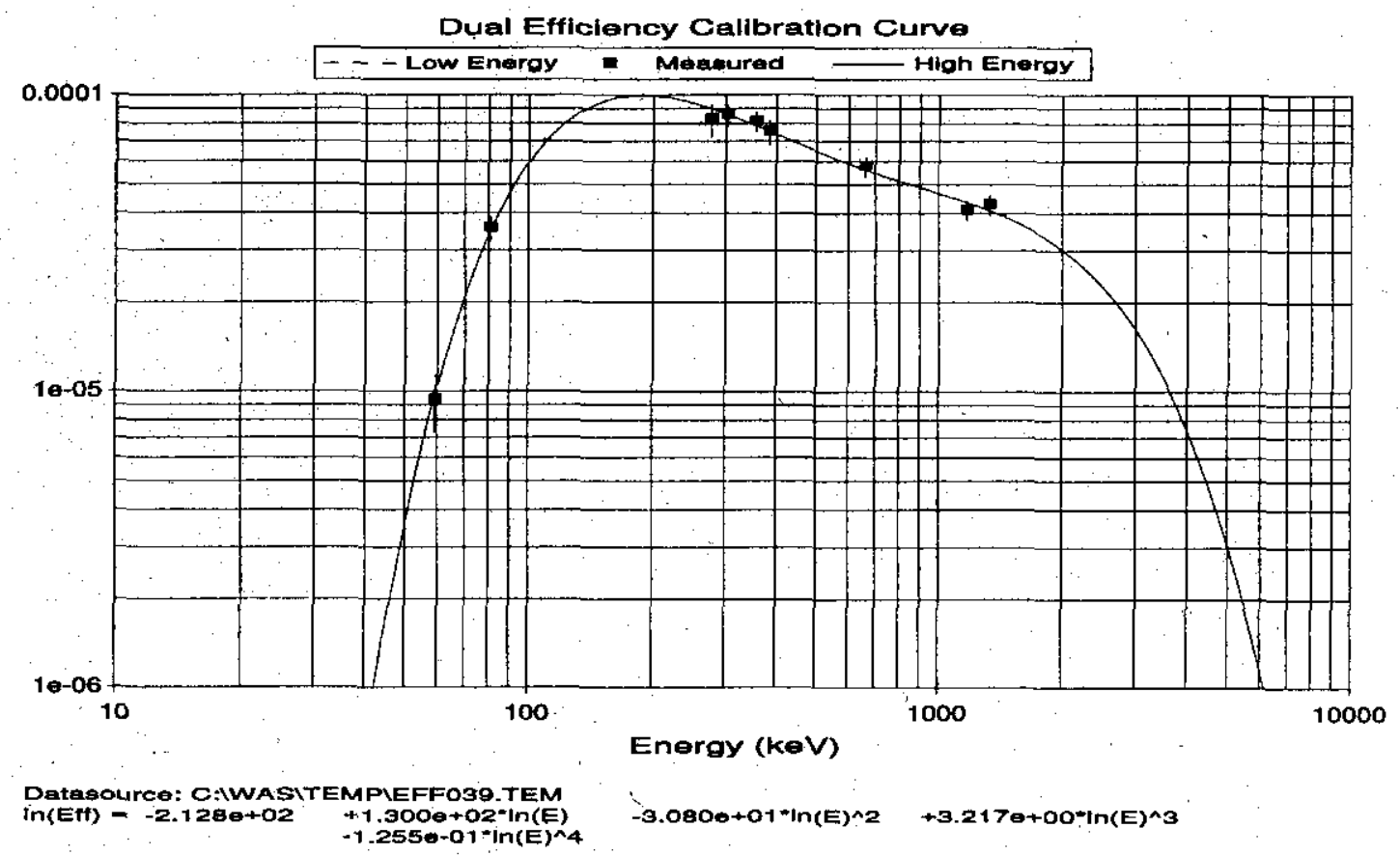

Seg 11, SEGe 1, Drum position 2. 
HNF-5148, Rev. 2

Particle Board Drum, density $=0.65625 \mathrm{gms} / \mathrm{cc}$, No Shield (collimator). Spectrum Seq \# 3992

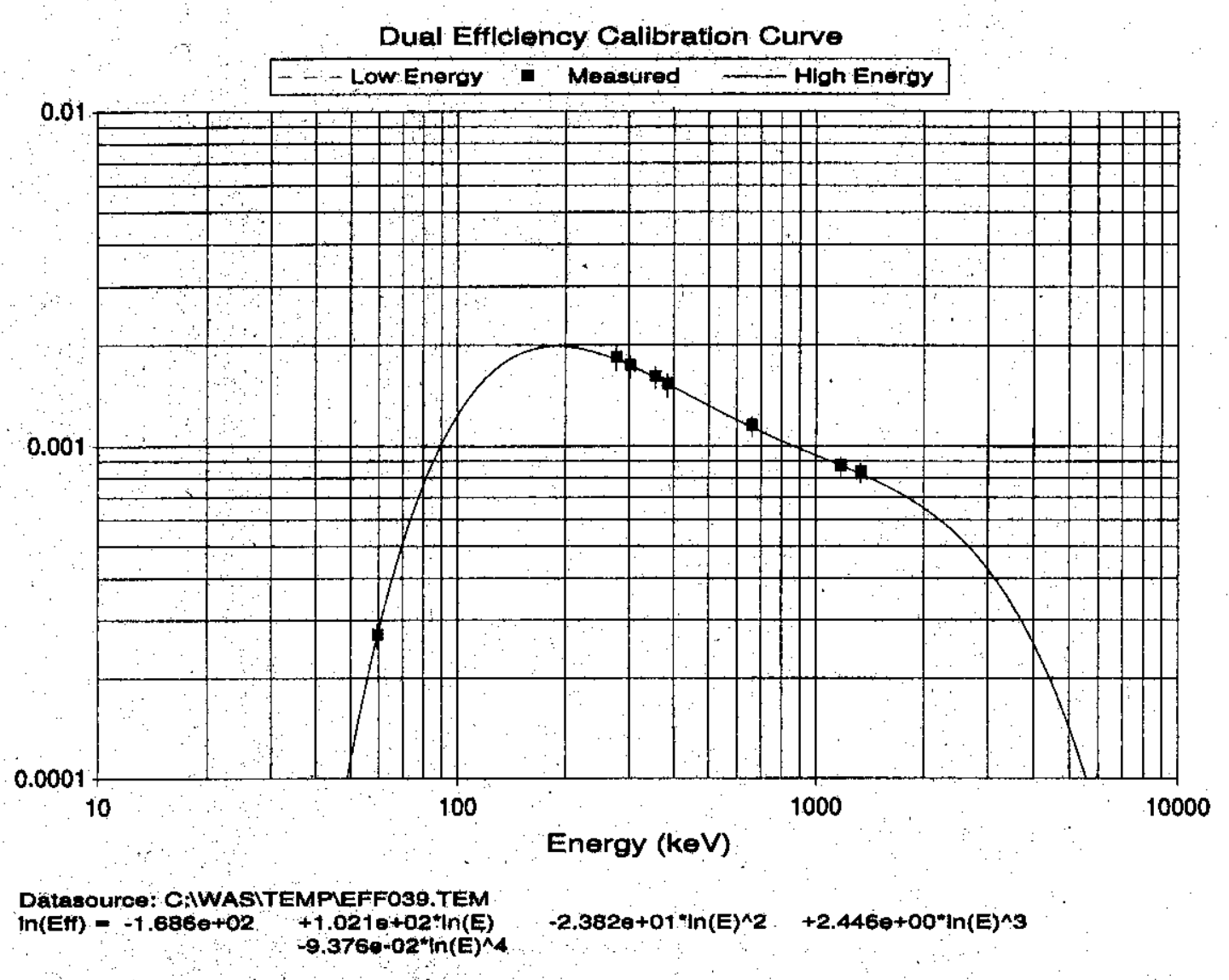


HNF-5148, Rev. 2

Particle Board Drum, density $=0.65625 \mathrm{gms} / \mathrm{cc}$, No Shield (collimator). Spectrum Seq \# 3993

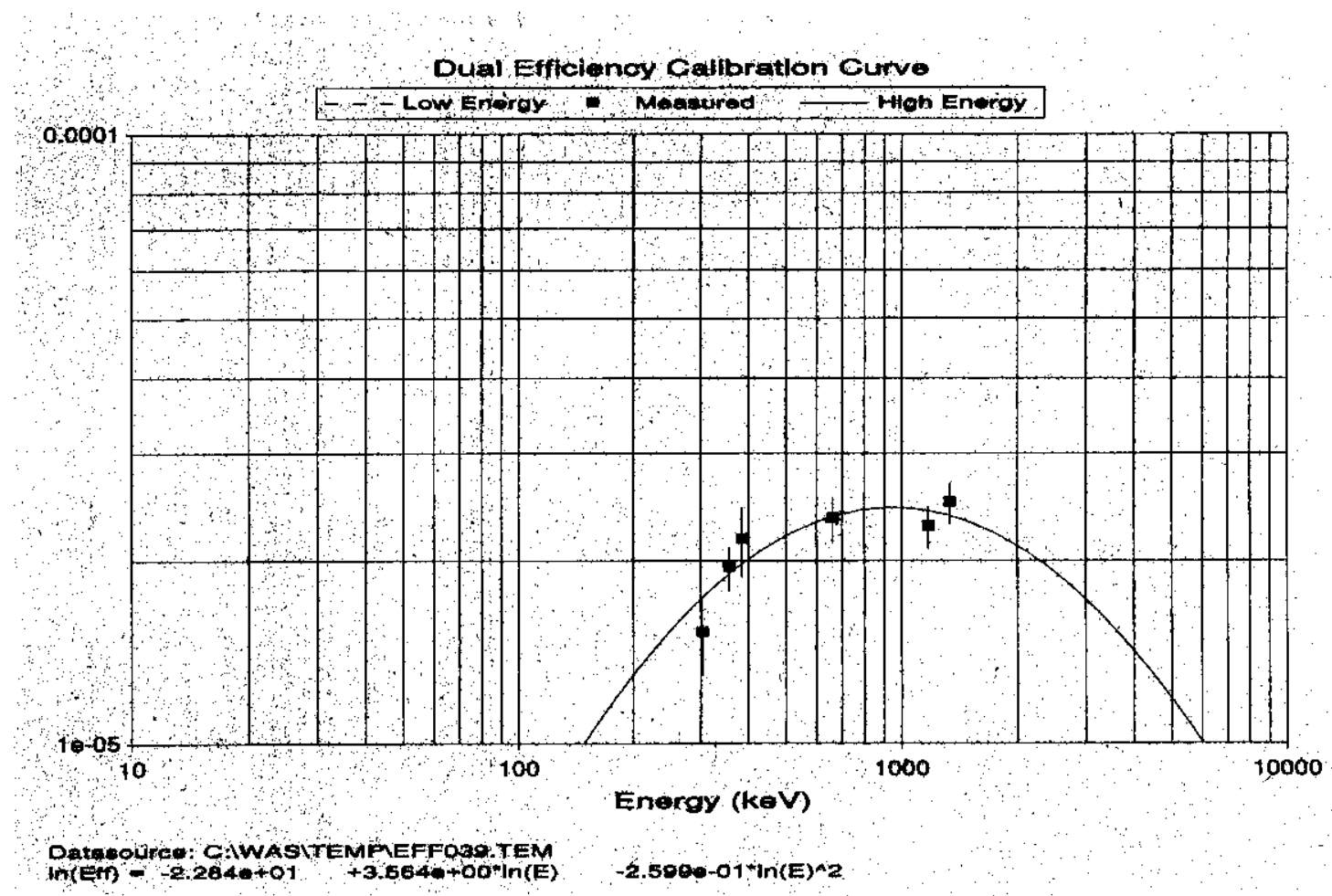

Seg 2, SEGe 4, Drum position 2.

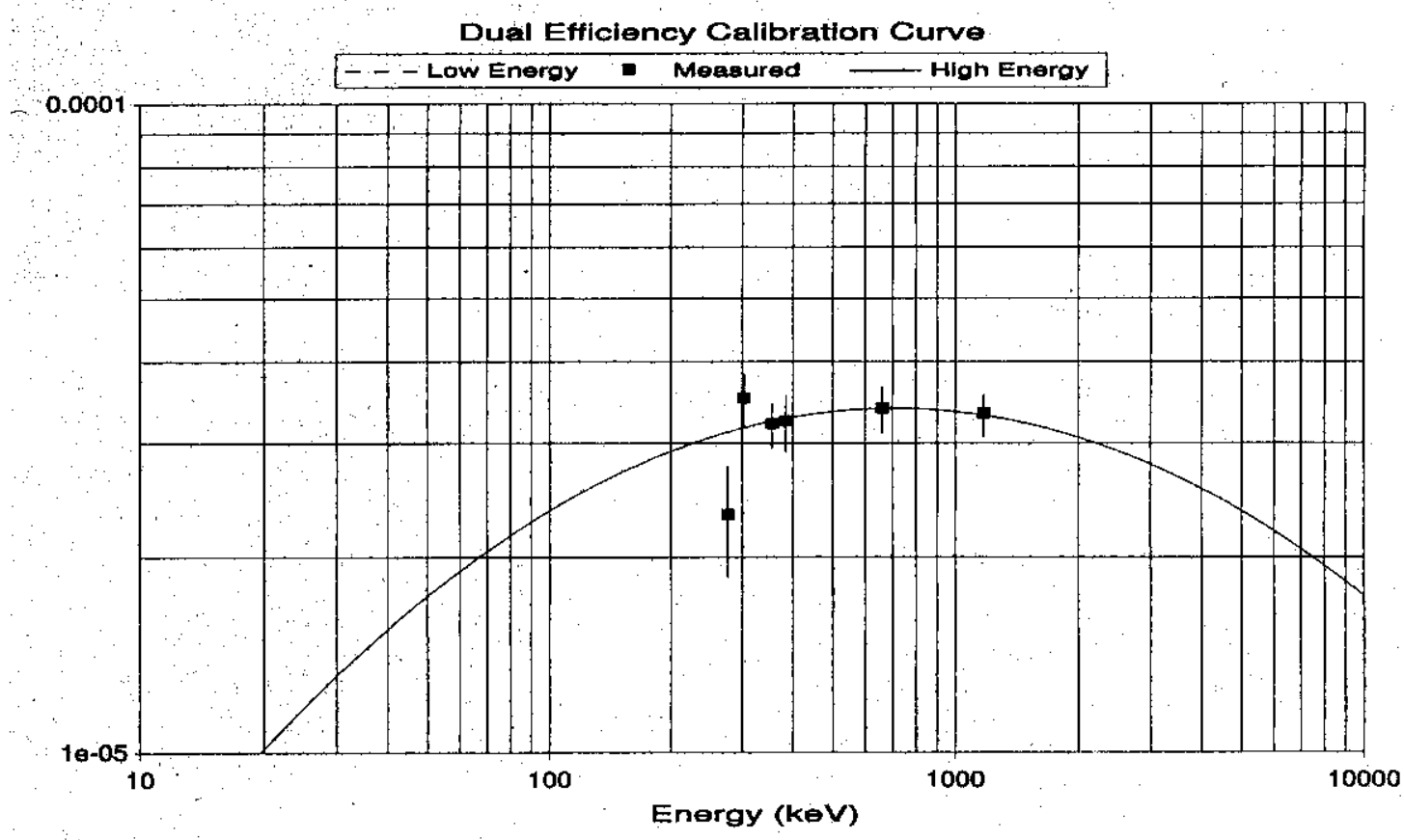

Datasource: CIWASITEMPIEFF039.TEM $\ln (E H)=-1.4390+01+1.249 e+00^{*} \ln (E)$

Seg 3, SEGe 1, Drum position 3. 
Particle Board Drum, density $=0.65625 \mathrm{gms} / \mathrm{cc}$, No Shield (collimator). Spectrum Seq \# 3993

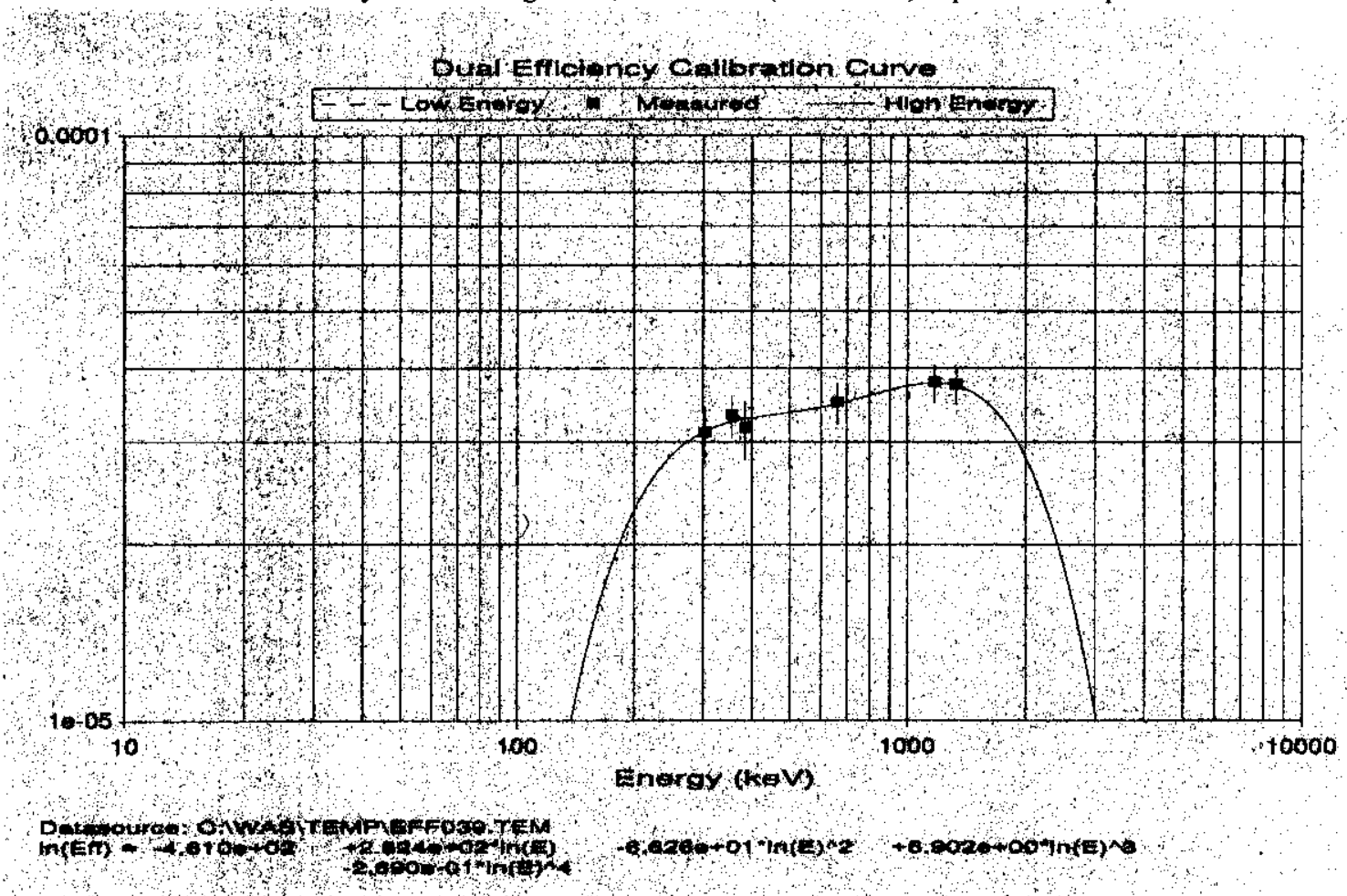

Seg 4, SEGe 3, Drum position 1.

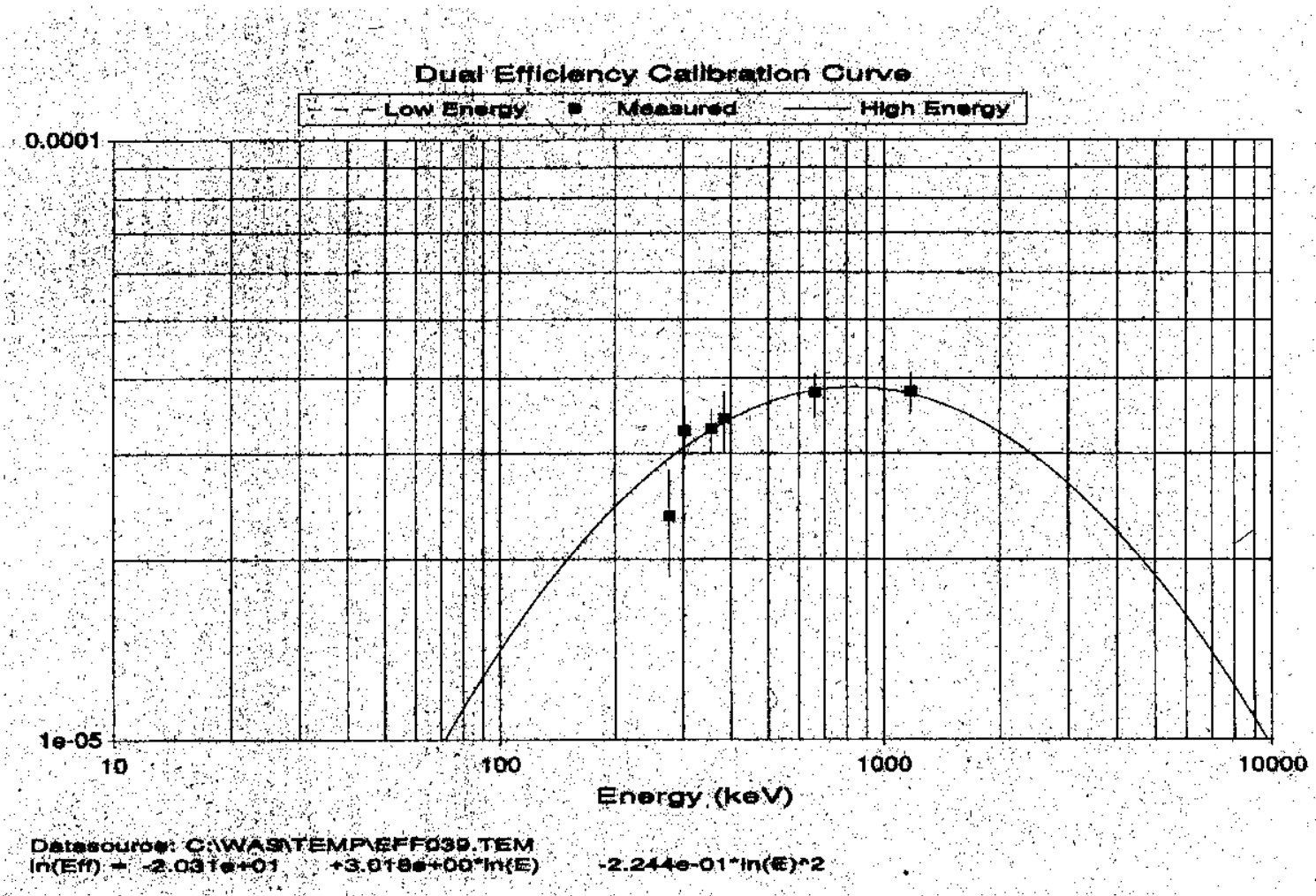

Seg 5, SEGe 3, Drum position 2. 
HNF-5148, Rev. 2

Particle Board Drum, density $=0.65625$ gms $/ \mathrm{cc}$, No Shield (collimator). Spectrum Seq \# 3993

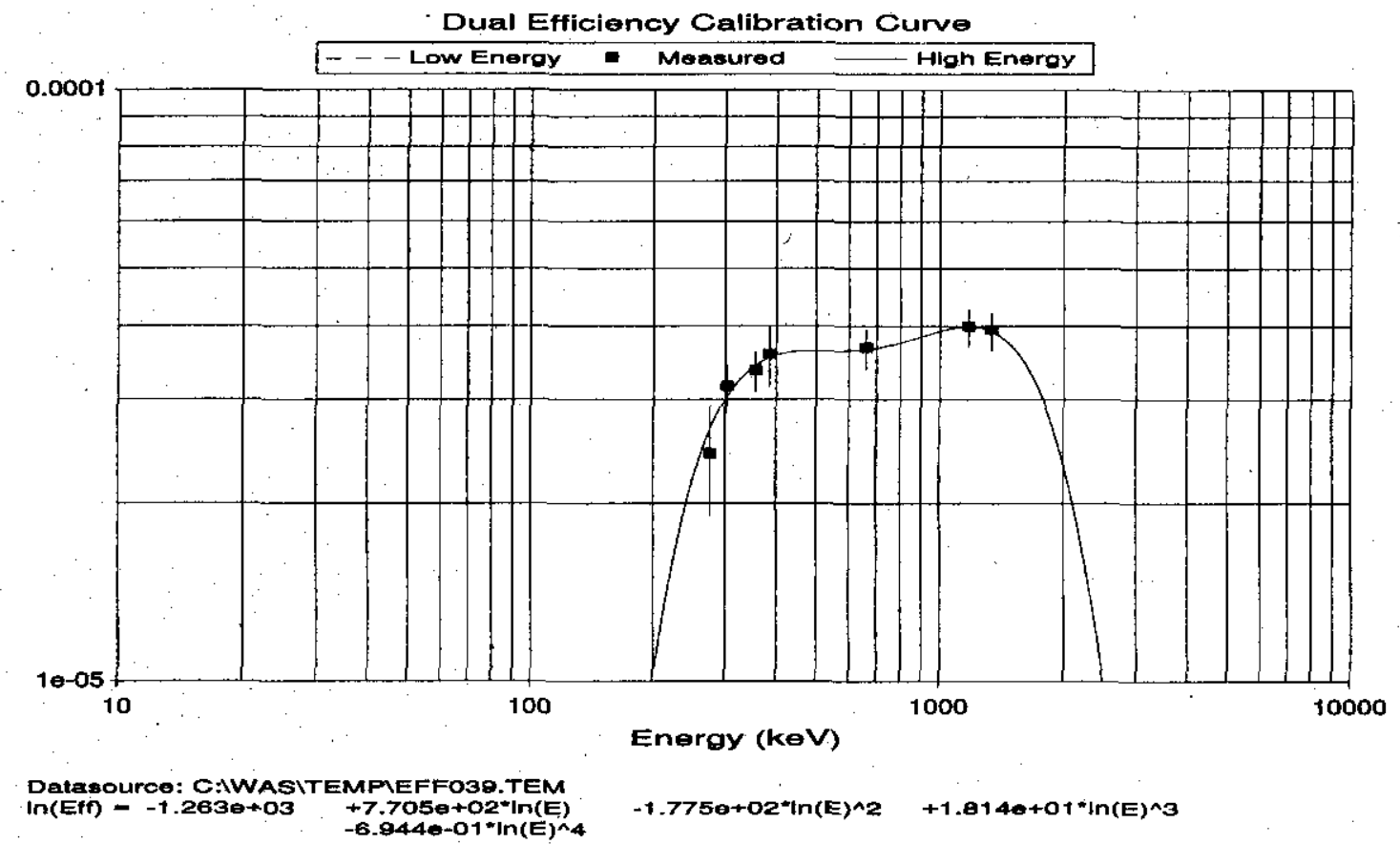

Seg 6, SEGe 3, Drum position 3.



Seg 7, SEGe 2, Drum position 1 . 
HNF-5148, Rev. 2

Particle Board Drum, density $=0.65625$ gms $/ \mathrm{cc}$, No Shield (collimator). Spectrum Seq \# 3993

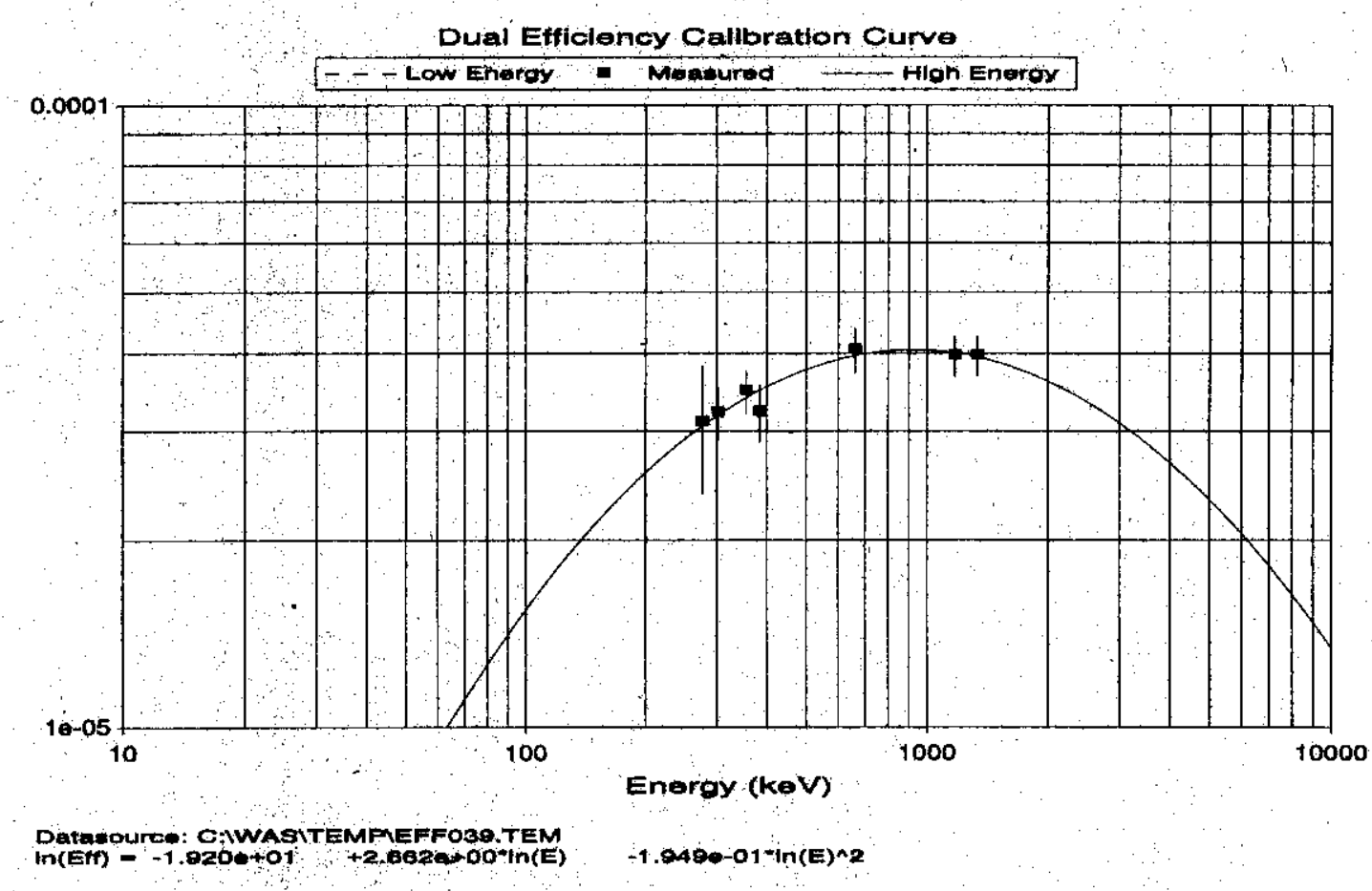

Seg 8, SEGe 2, Drum position 2.

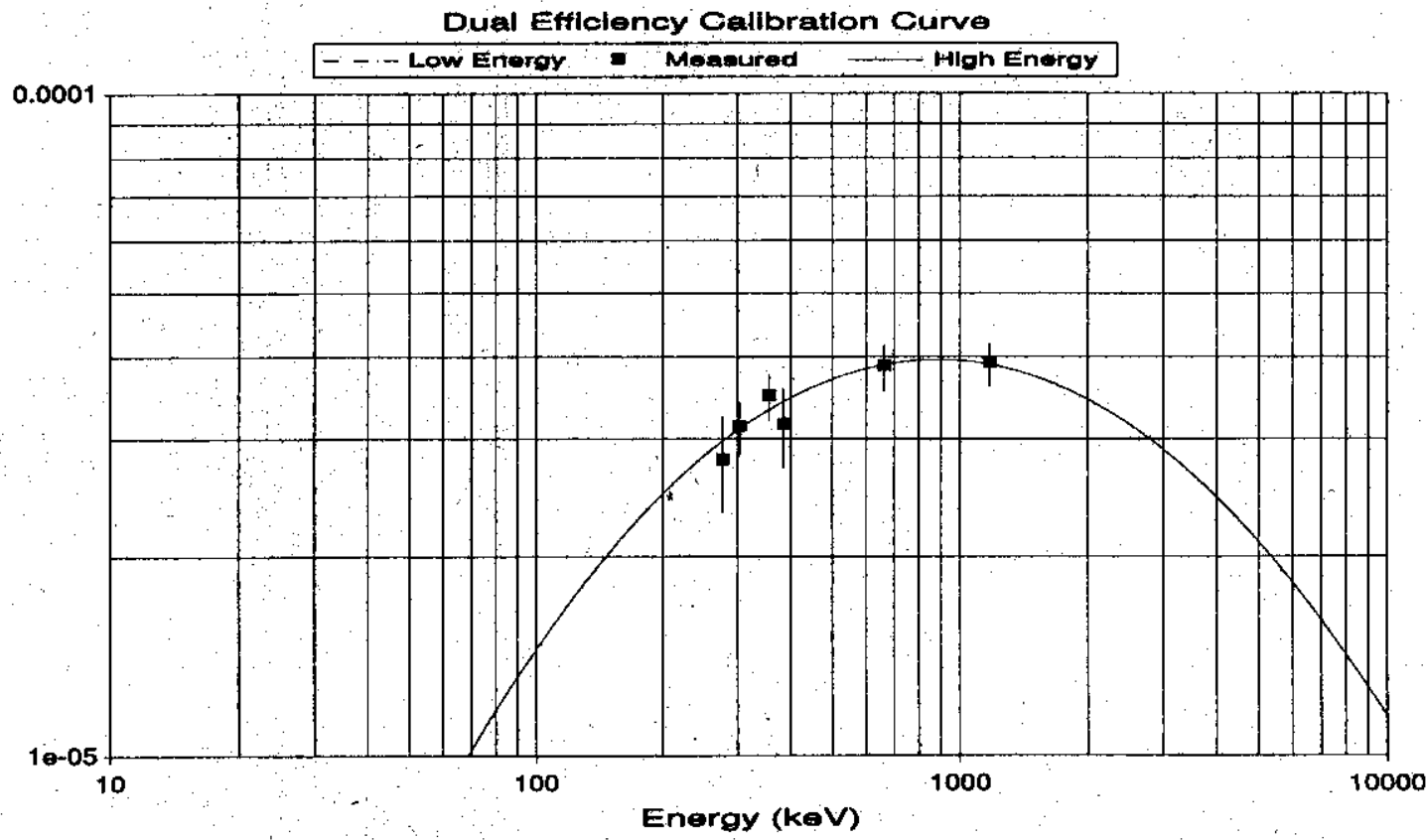

Datasource: C:IWASITEMPIEFFO39.TEM $\ln (E H)=-1.905 \theta+01+2.8610+00 *$ In(E)

Seg 9, SEGe 2, Drum position 3. 
Particle Board Drum, density $=0.65625$ gms $/ \mathrm{cc}$, No Shield (collimator). Spectrum Seq \#3993

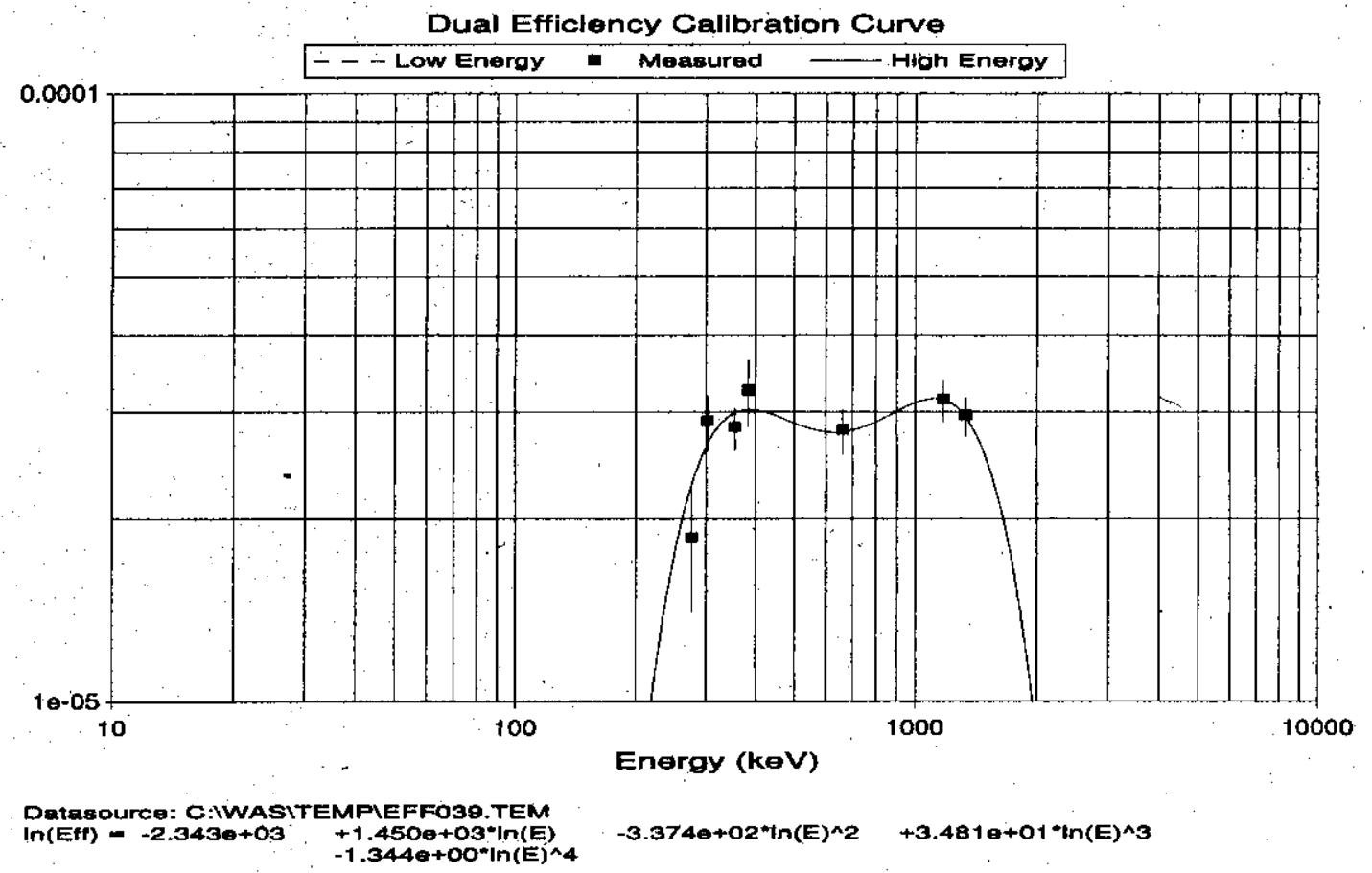

Seg 10, SEGe 1, Drum position 1.

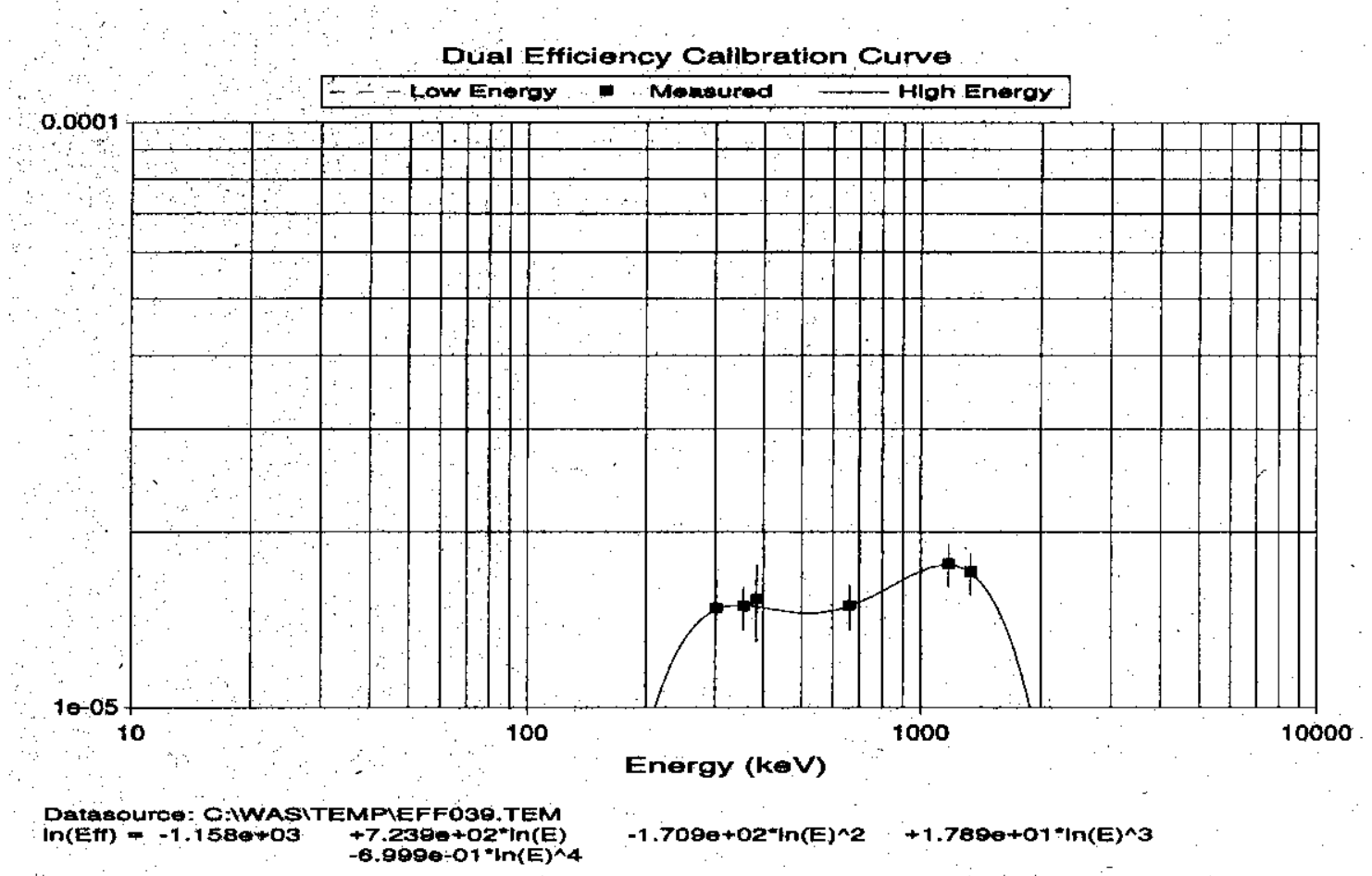

Seg 11, SEGe 1, Drum position 2. 
HNF-5148, Rev. 2

Particle Board Drum, density $=0.65625$ gms/cc, No Shield (collimator). Spectrum Seq \# 3993

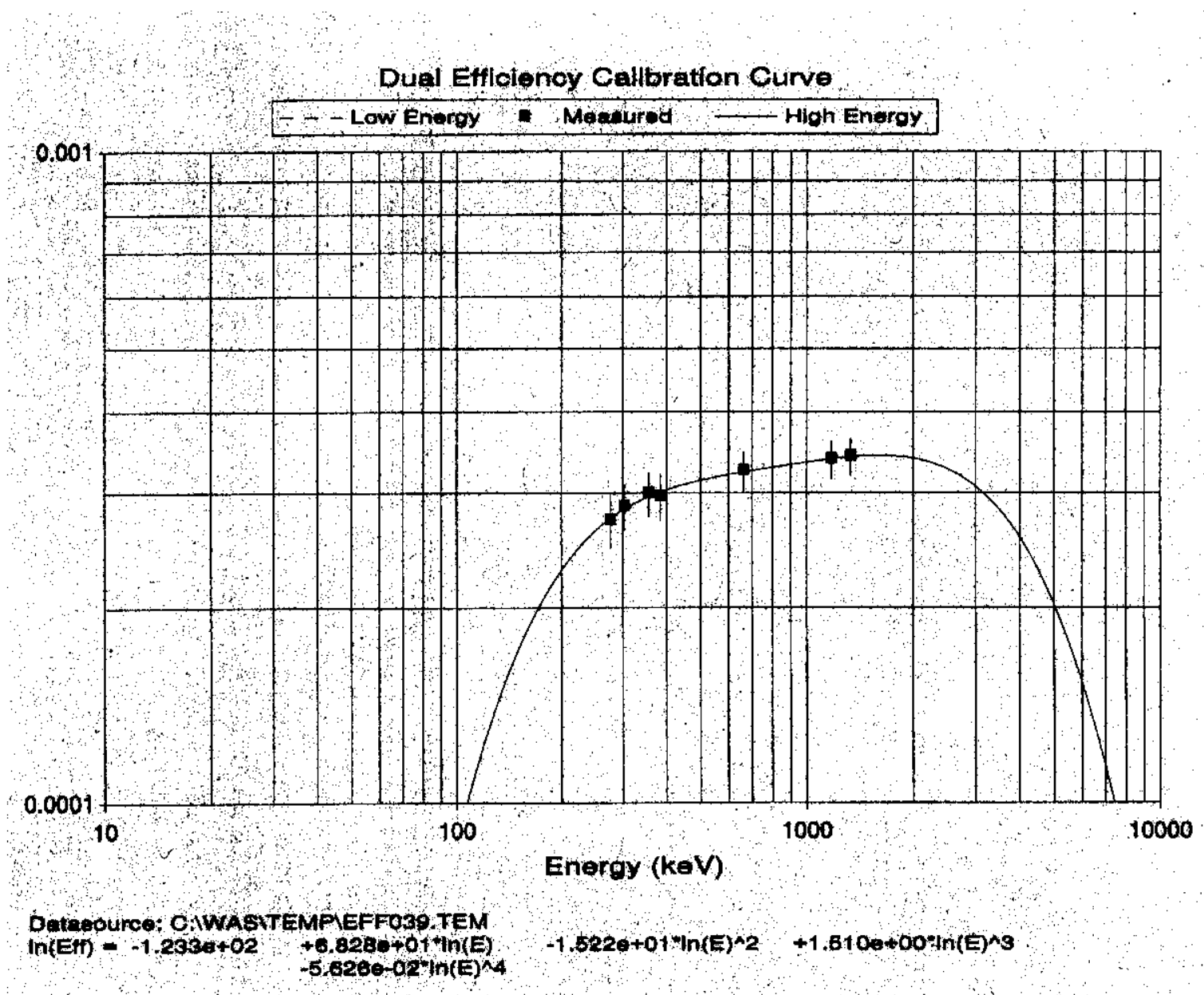


HNF-5 148, Rev. 2

Sand Drum, density $=1.5601 \mathrm{gms} / \mathrm{cc}$, No Shield (collimator). Spectrum Seq \# 3991

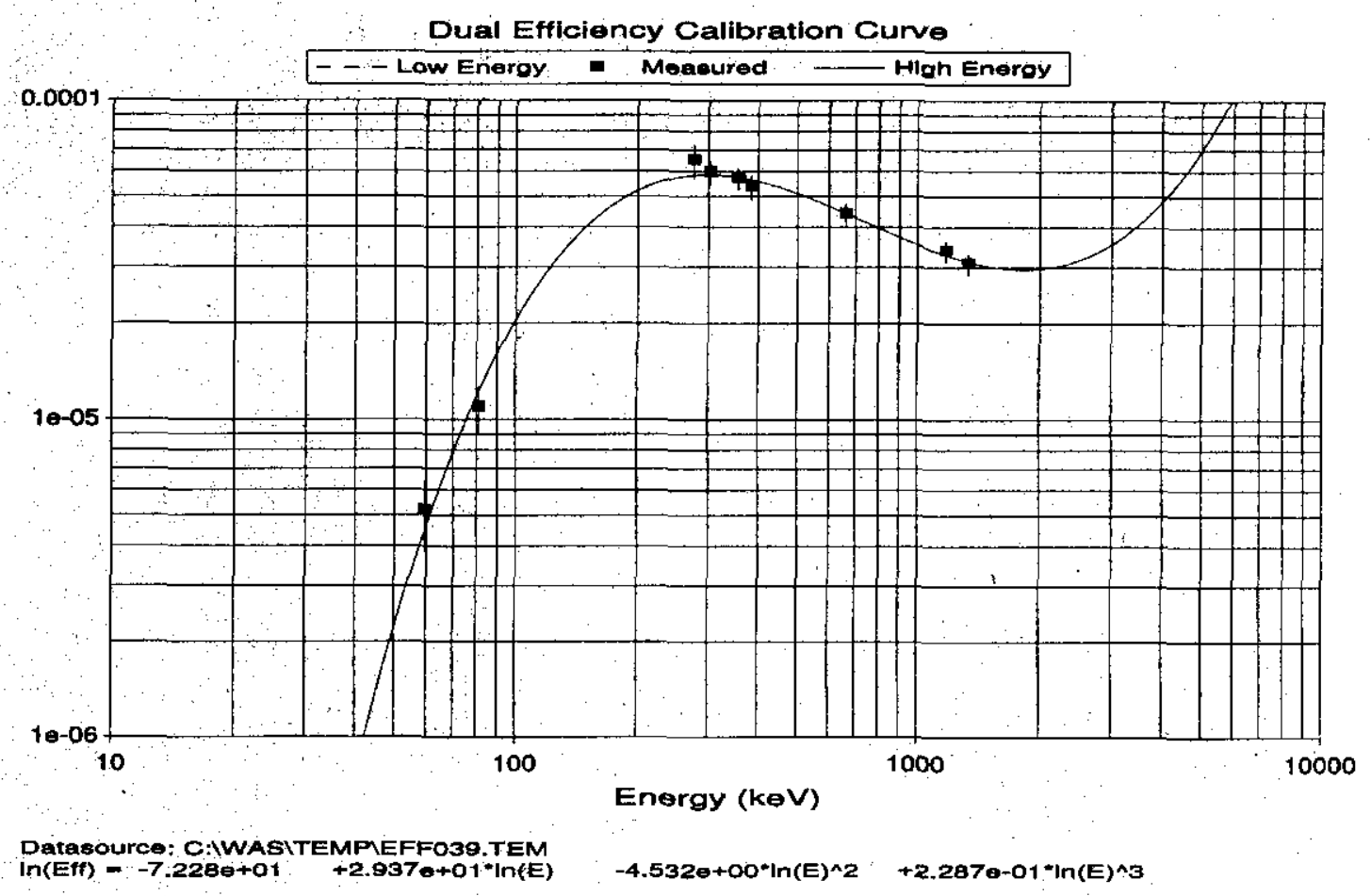

Seg 2, SEGe 4, Drum position 2.

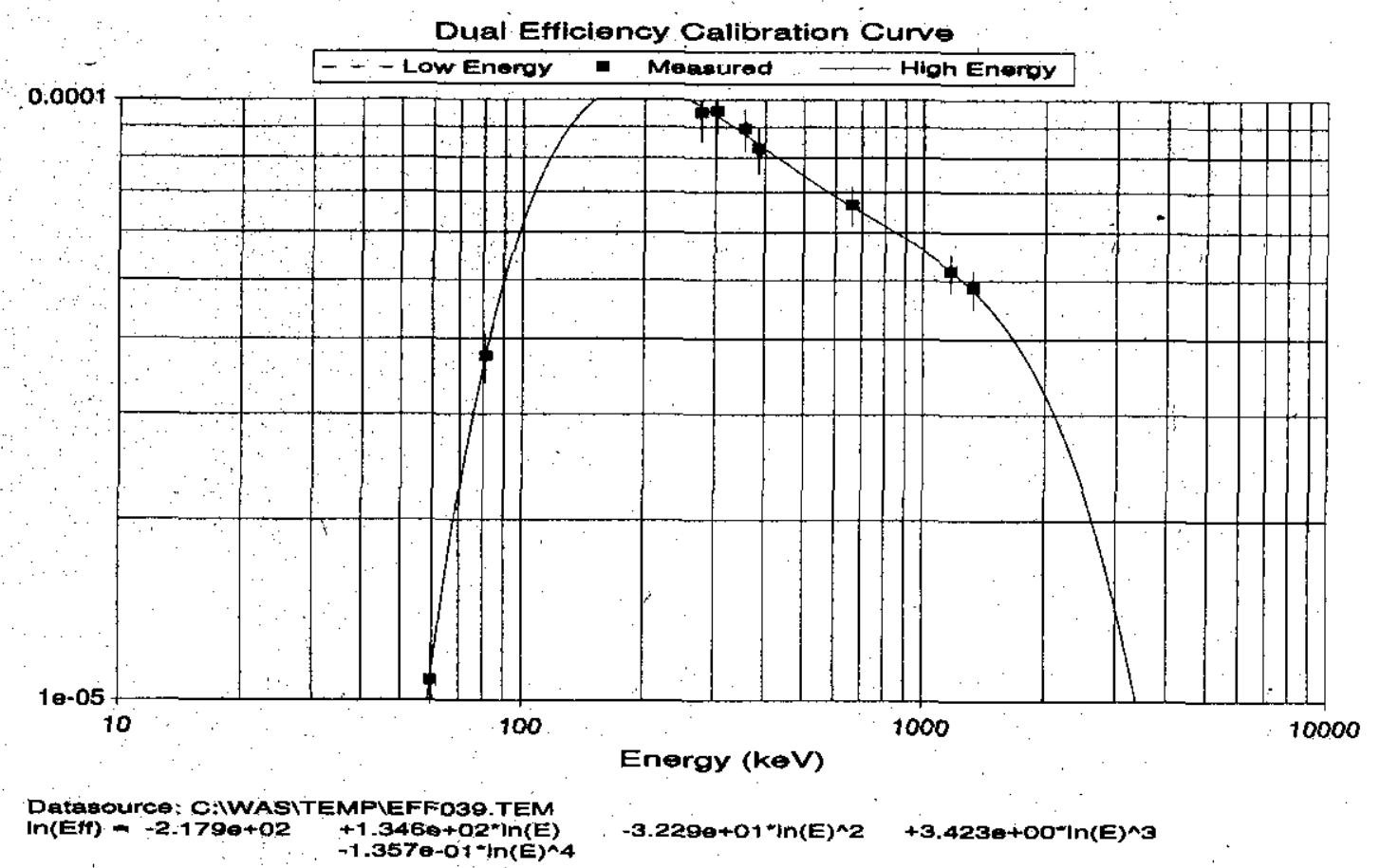

Seg 3, SEGe 4, Drum position 3. 
HNF-5148, Rev. 2

Sand Drum, density $=1.5601 \mathrm{gms} / \mathrm{cc}$, No Shield (collimator). Spectrum Seq \# 3991

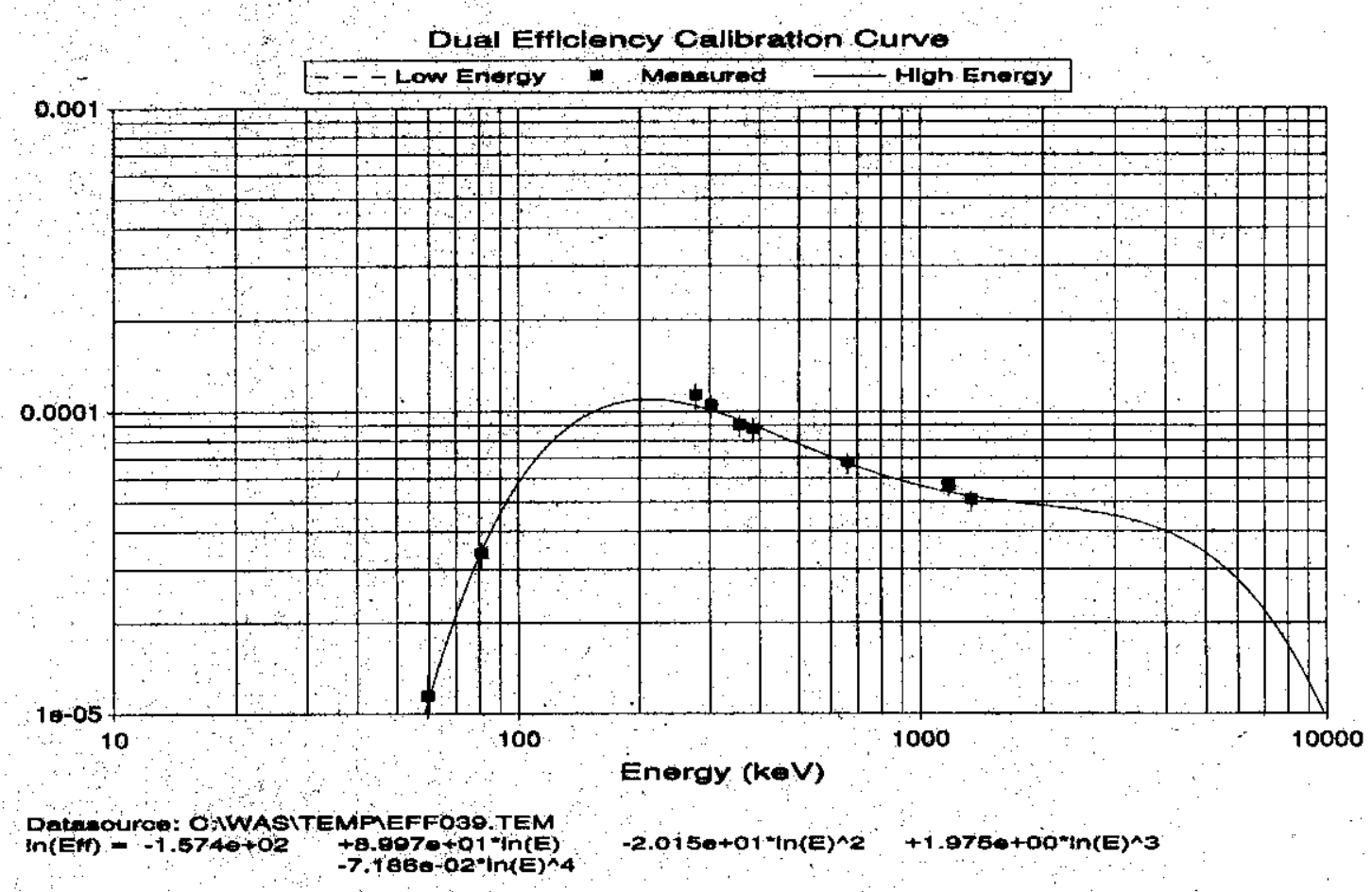

Seg 4, SEGe 3, Drum position 1 .

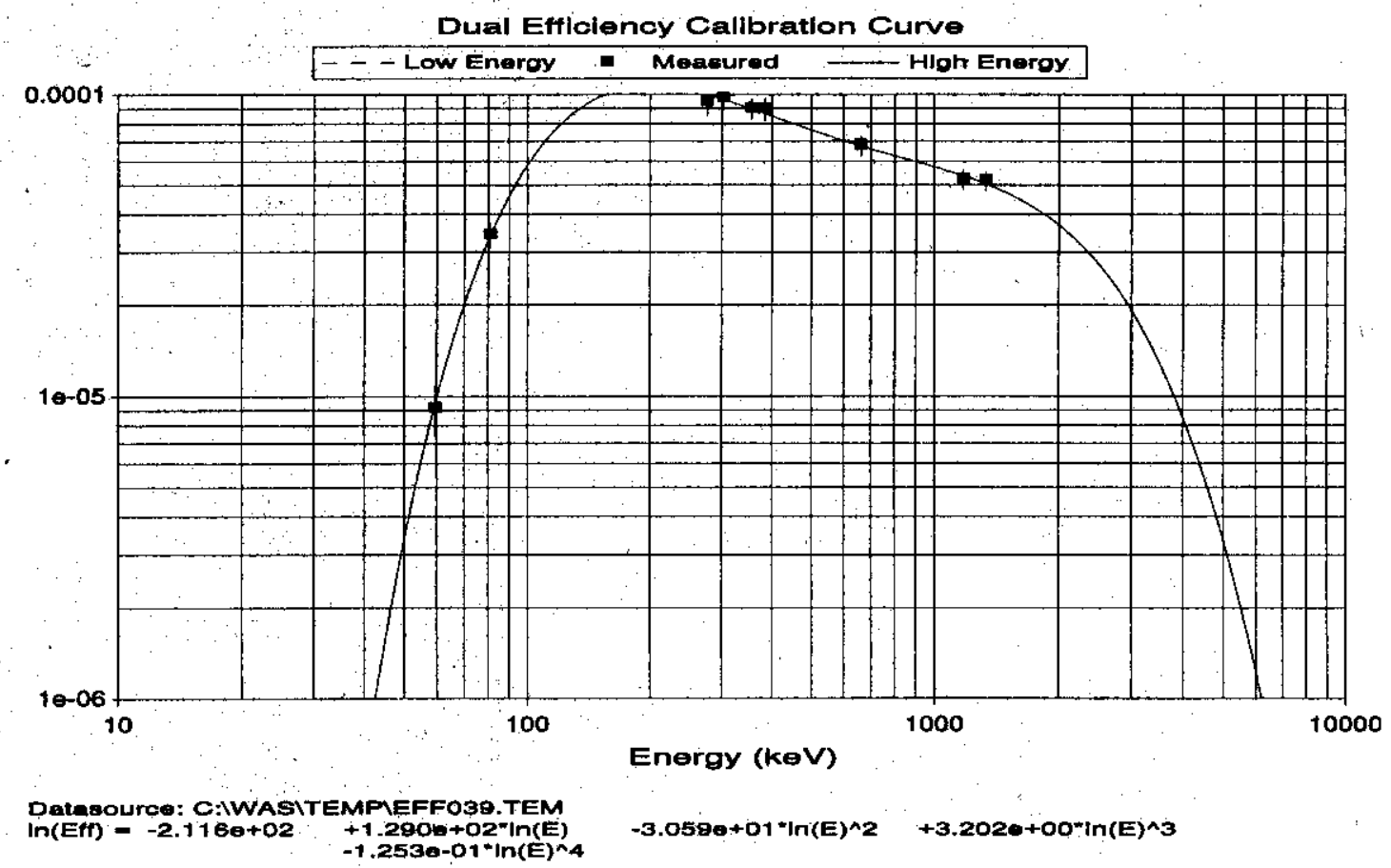

Seg 5, SEGe 3, Drum position 2. 
HNF-5148, Rev. 2

Sand Drum, density $=1.5601 \mathrm{gms} / \mathrm{cc}$, No Shield (collimator). Spectrum Seq \# 3991

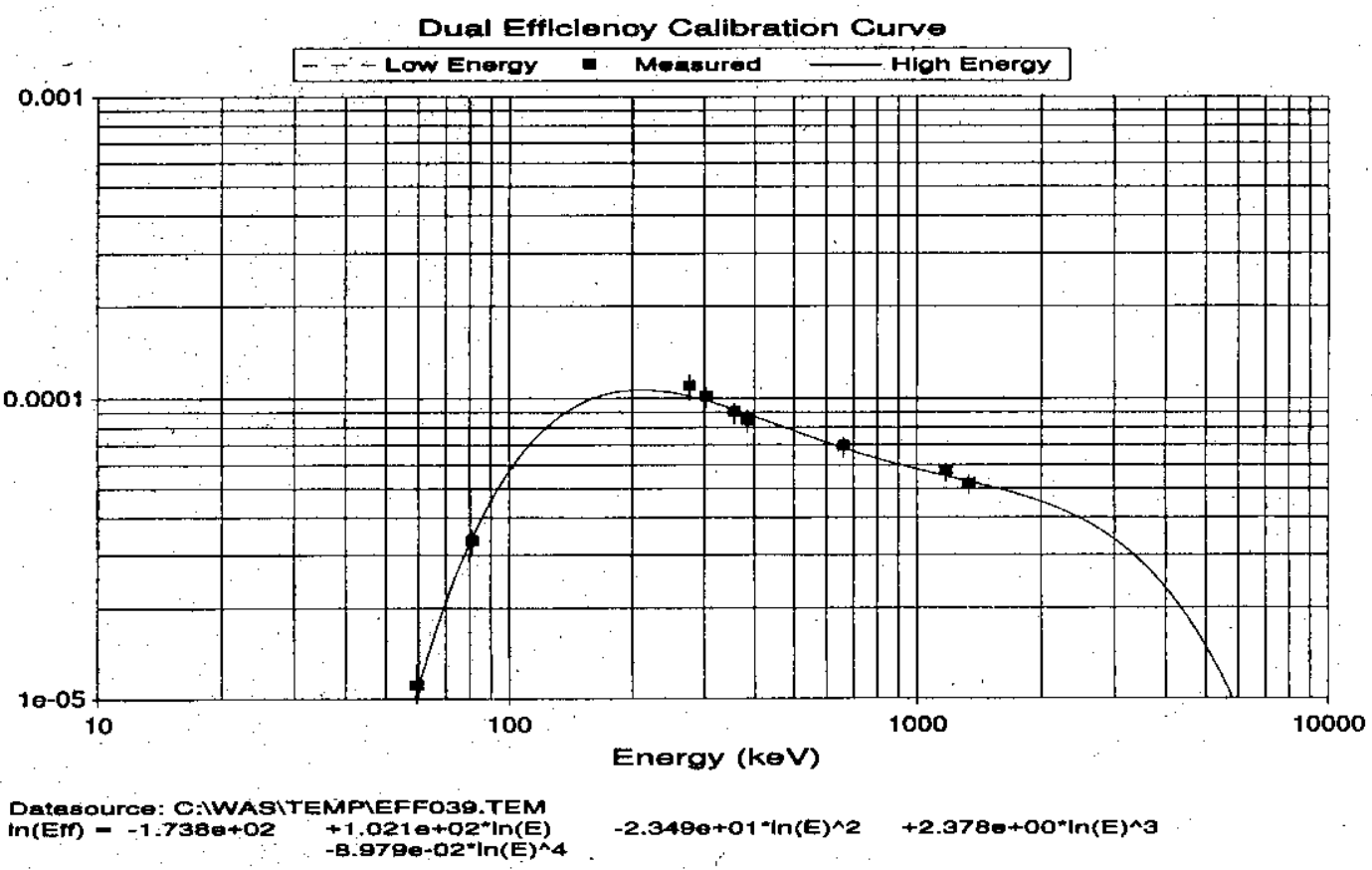

Seg 6, SEGe 3, Drum position 3.

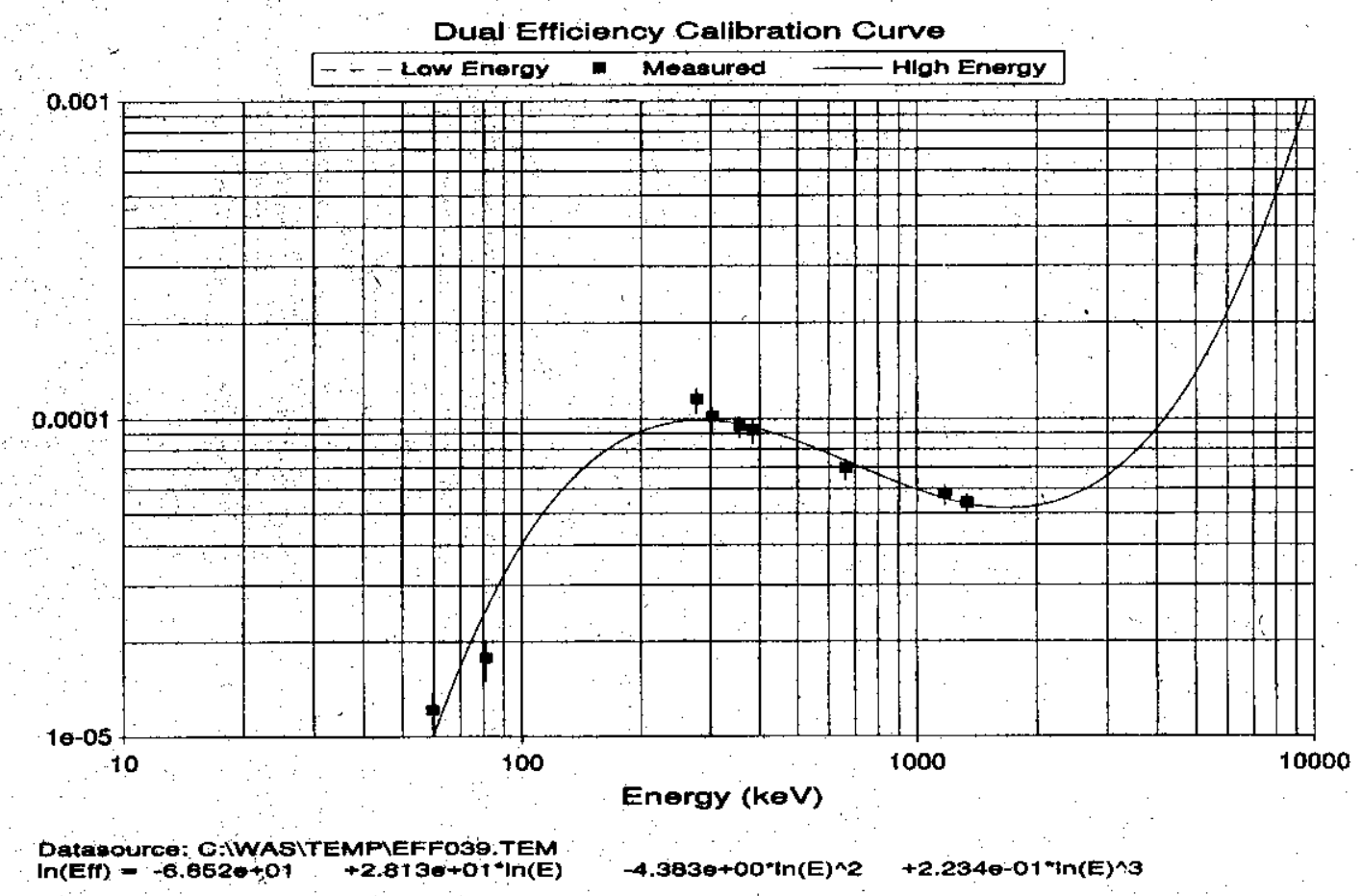

Seg 7, SEGe 2, Drum position 1 . 
HNF-5148, Rev. 2

Sand Drum, density $=1.5601 \mathrm{gms} / \mathrm{cc}$, No Shield (collimator). Spectrum Seq \# 3991

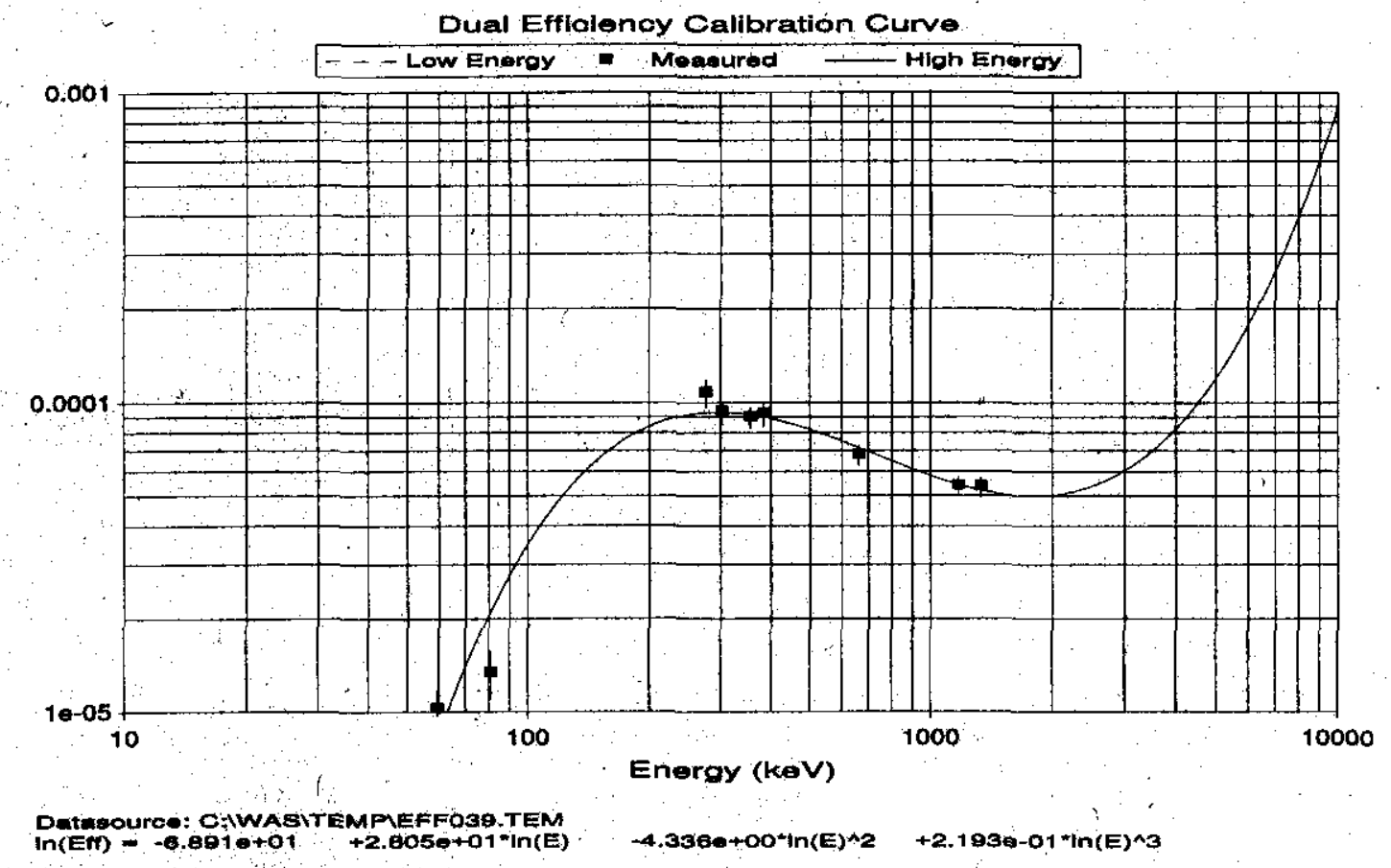

Seg 8, SEGe 2, Drum position 2.

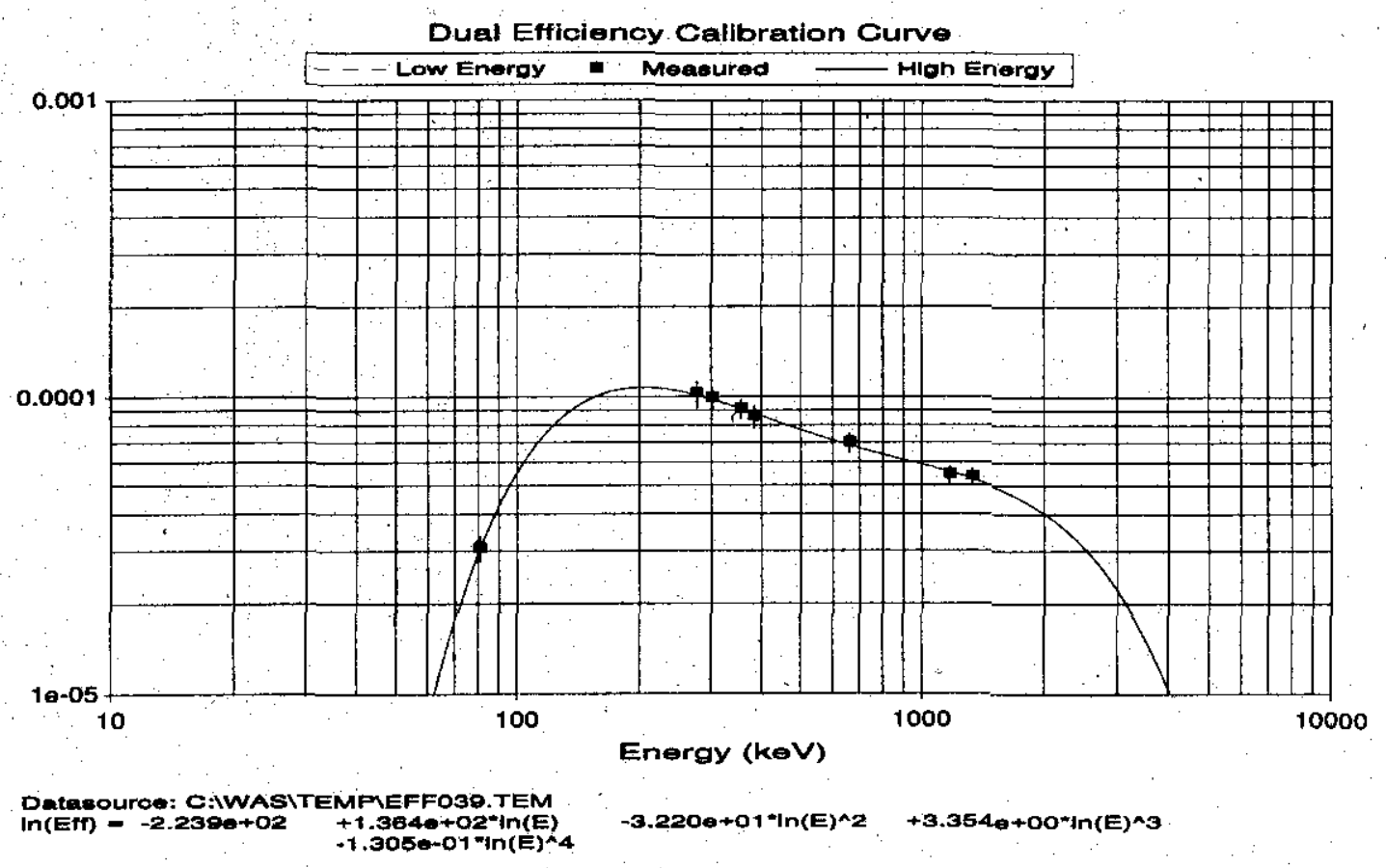

Seg 9, SEGe 2, Drum position 3. 
Sand Drum, density $=1.5601 \mathrm{gms} / \mathrm{cc}$, No Shield (collimator). Spectrum Seq \# 3991

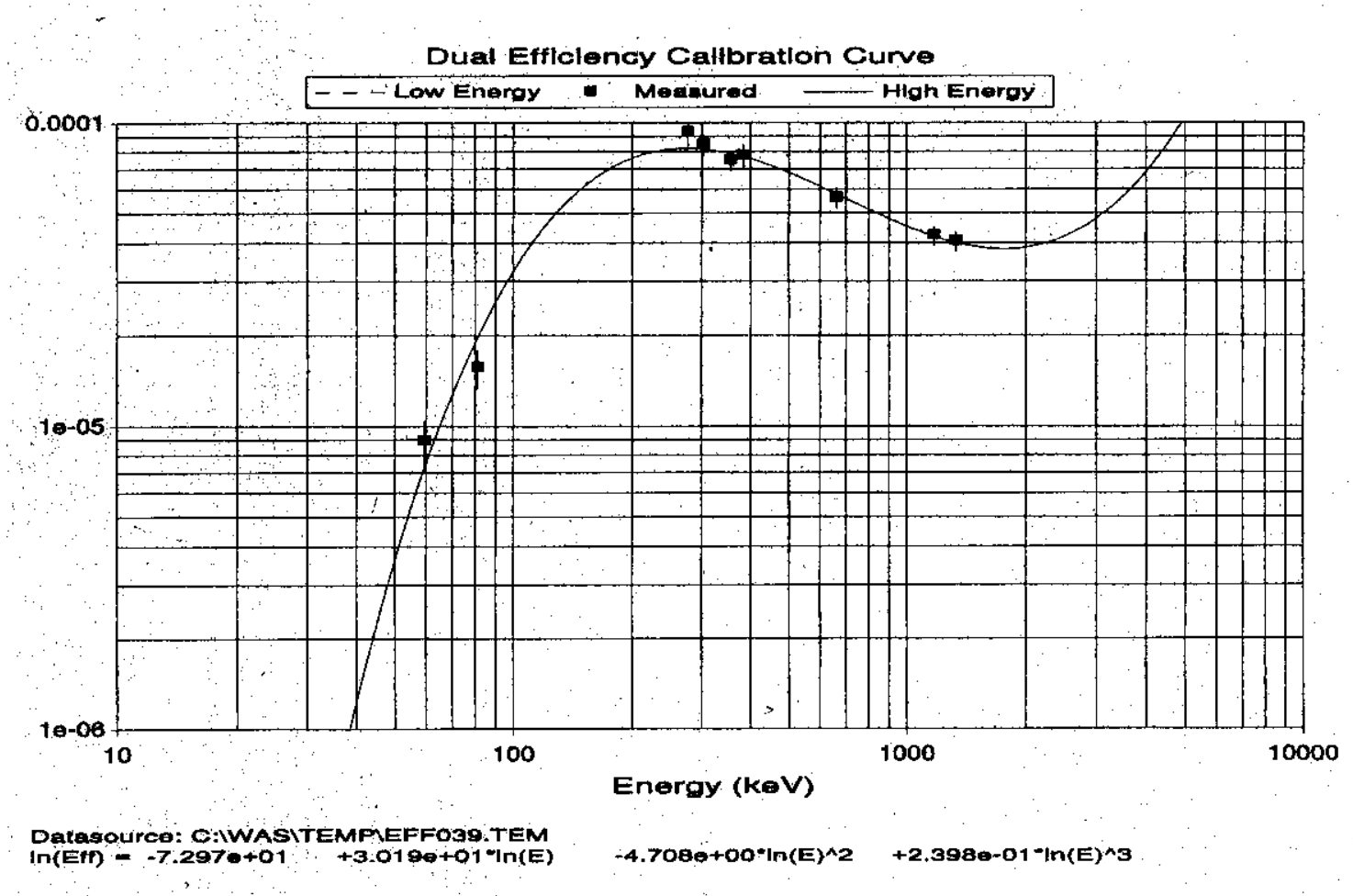

Seg 10, SEGe 1, Drum position 1.

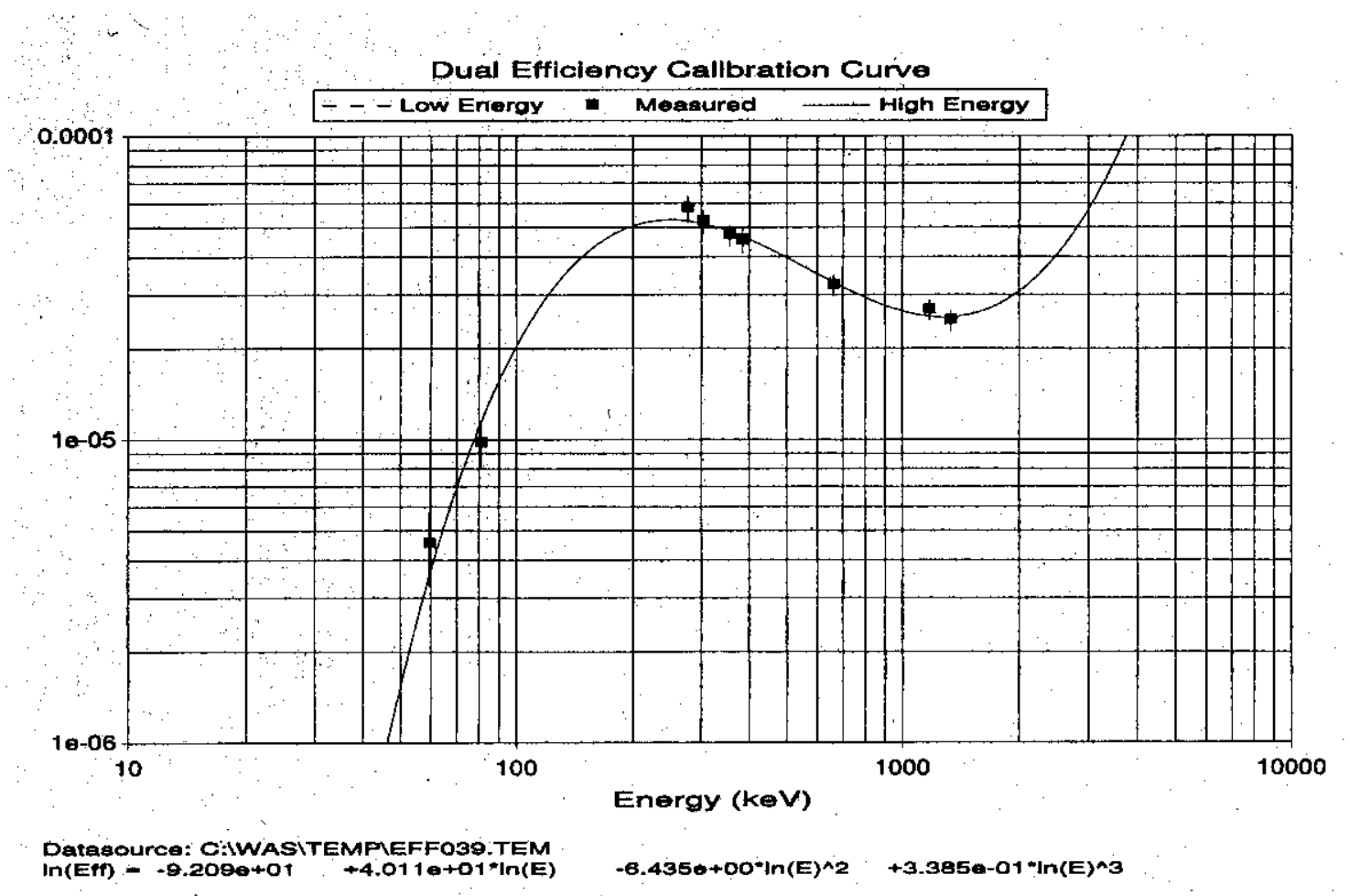

Seg 11, SEGe 1, Drum position 2 
HNF-5148, Rev. 2

Sand Drum, density $=1.5601 \mathrm{gms} / \mathrm{cc}$, No Shield (collimator). Spectrum Seq \# 3991

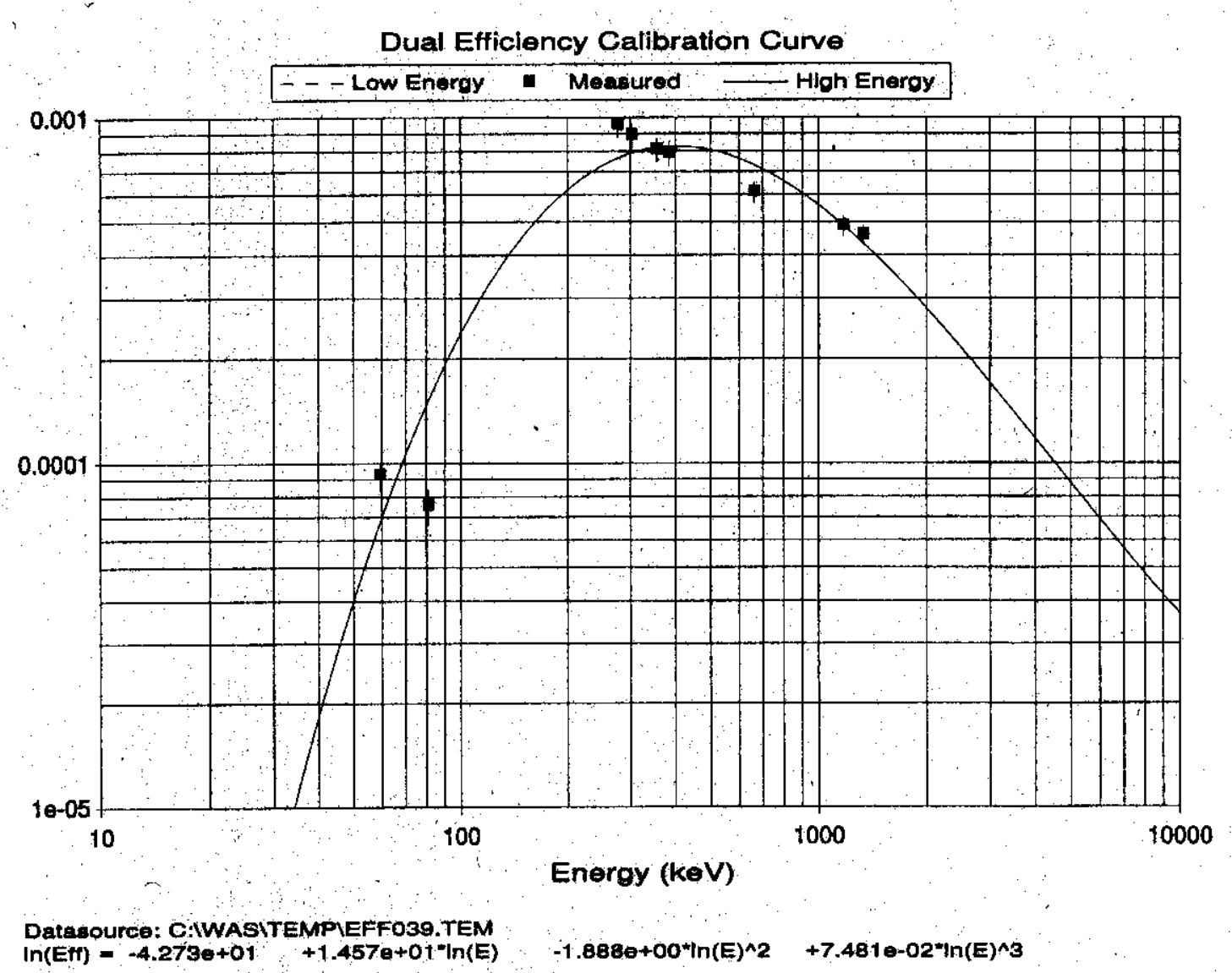

Sum Segments 
HNF-5148, Rev. 2

Sand Drum, density $=1.5601 \mathrm{gms} / \mathrm{cc}$ Shield (collimator). Spectrum Seq \# 3990

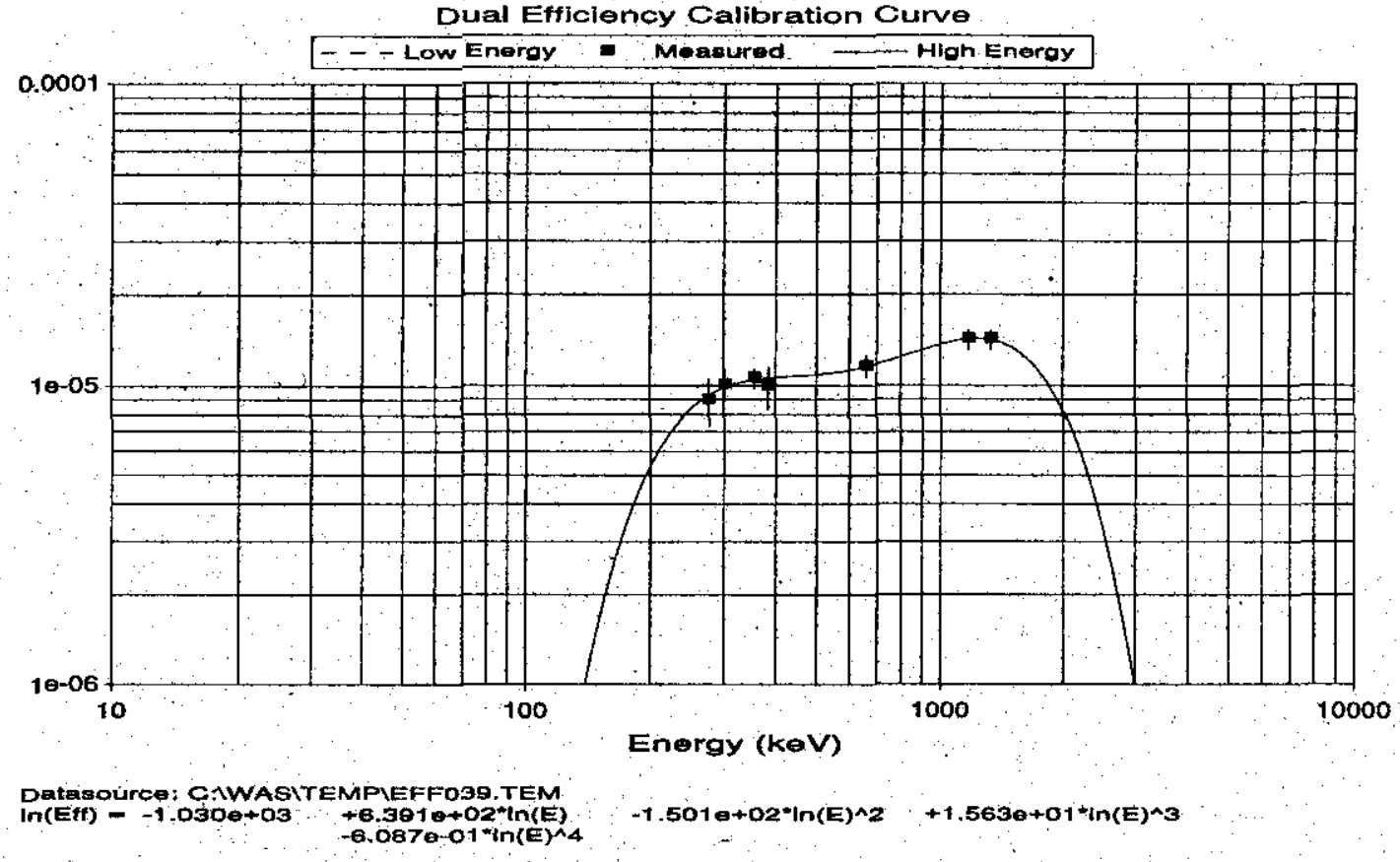

Seg 2, SEGe 4, Drum position 2.

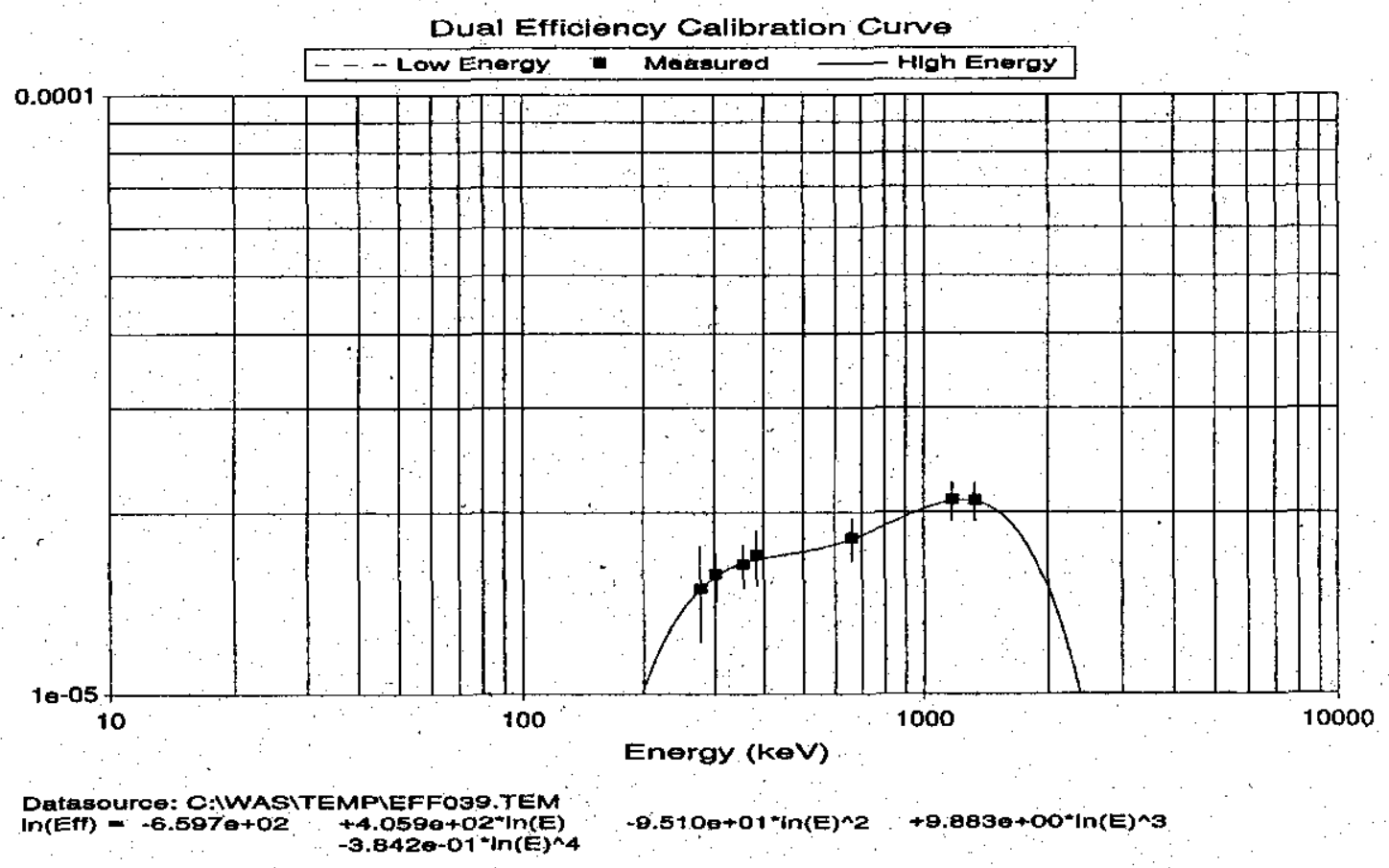

Seg 3, SEGe 4, Drum position 3. 
HNF-5148, Rev. 2

Sand Drum, density $=1.5601 \mathrm{gms} / \mathrm{cc}$ Shield (collimator). Spectrum Seq \# 3990

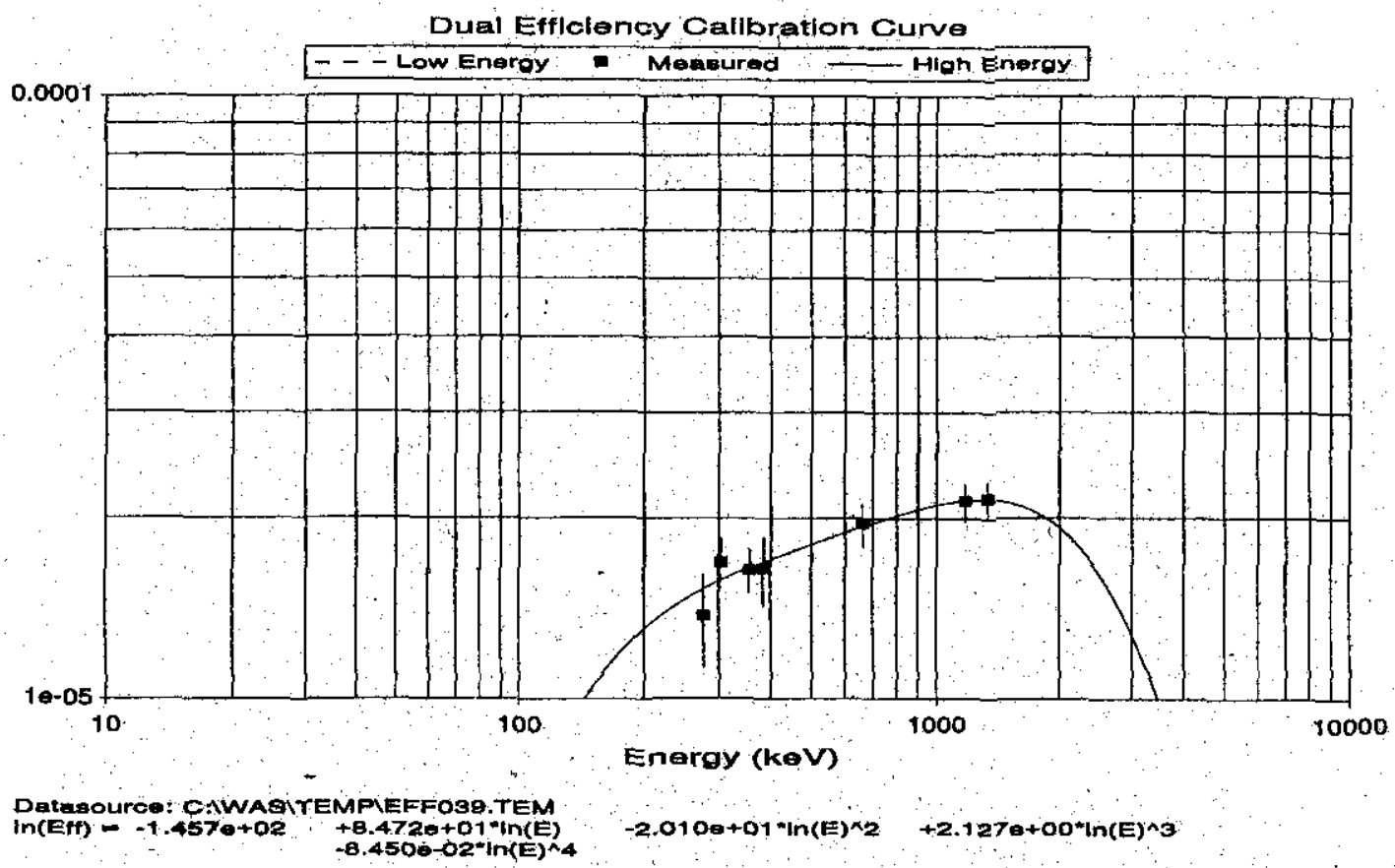

Seg 4, SEGe 3, Drum position 1.

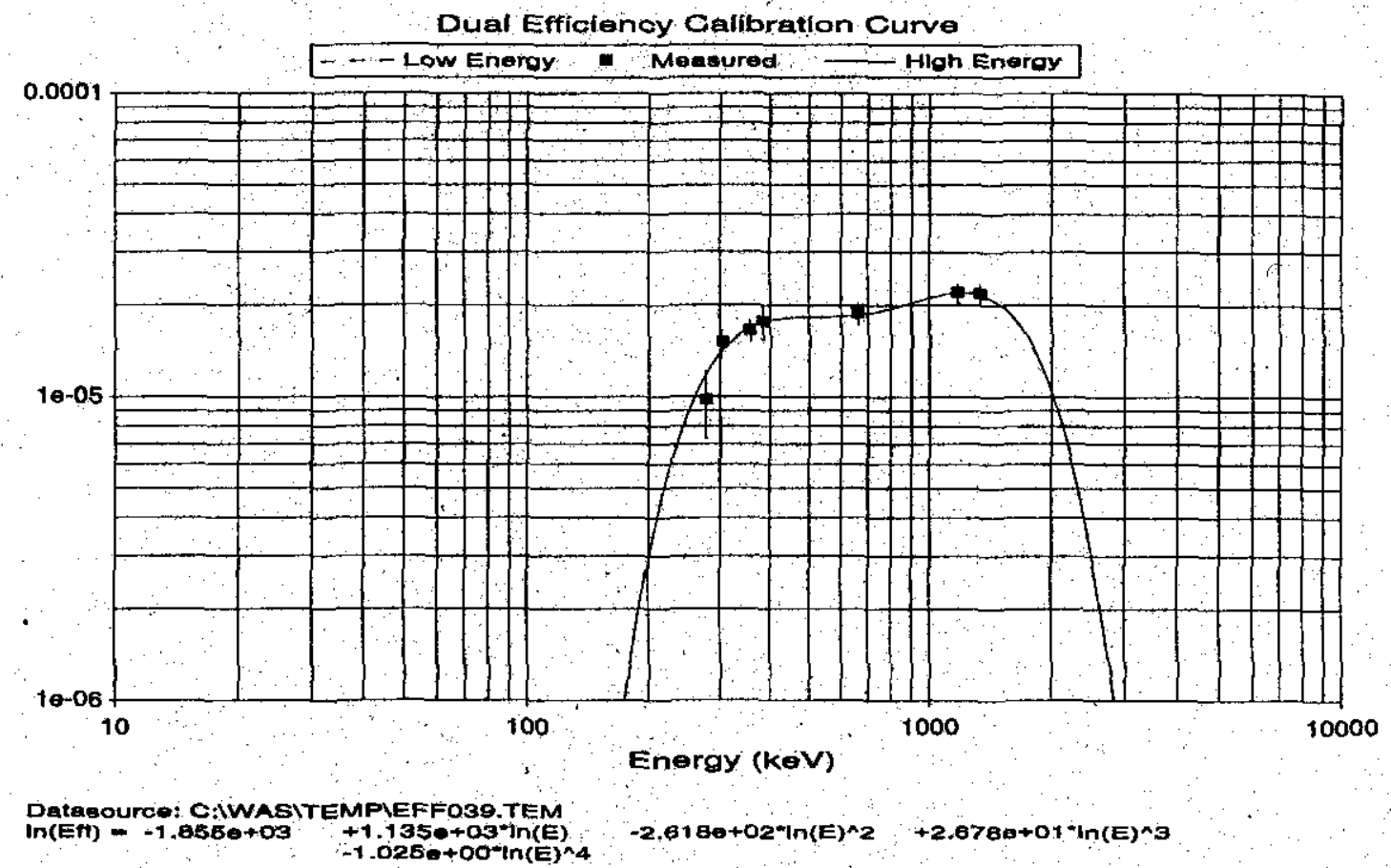

Seg 5, SEGe 3, Drum position 2. 
HNF-5148, Rev. 2

Sand Drum, density $=1.5601 \mathrm{gms} / \mathrm{cc}$ Shield (collimator). Spectrum Seq \#3990

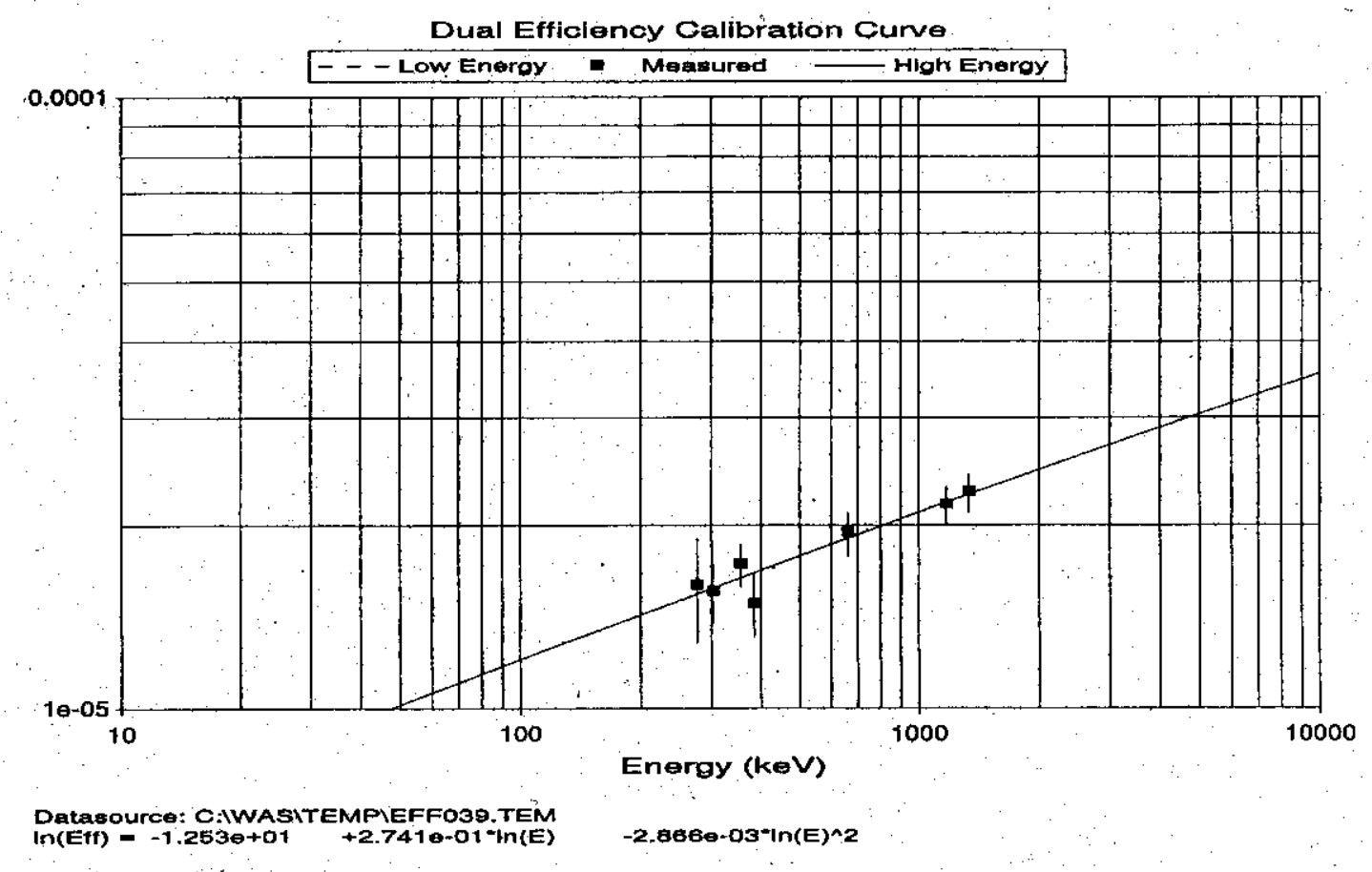

Seg 6, SEGe 3, Drum position 3.

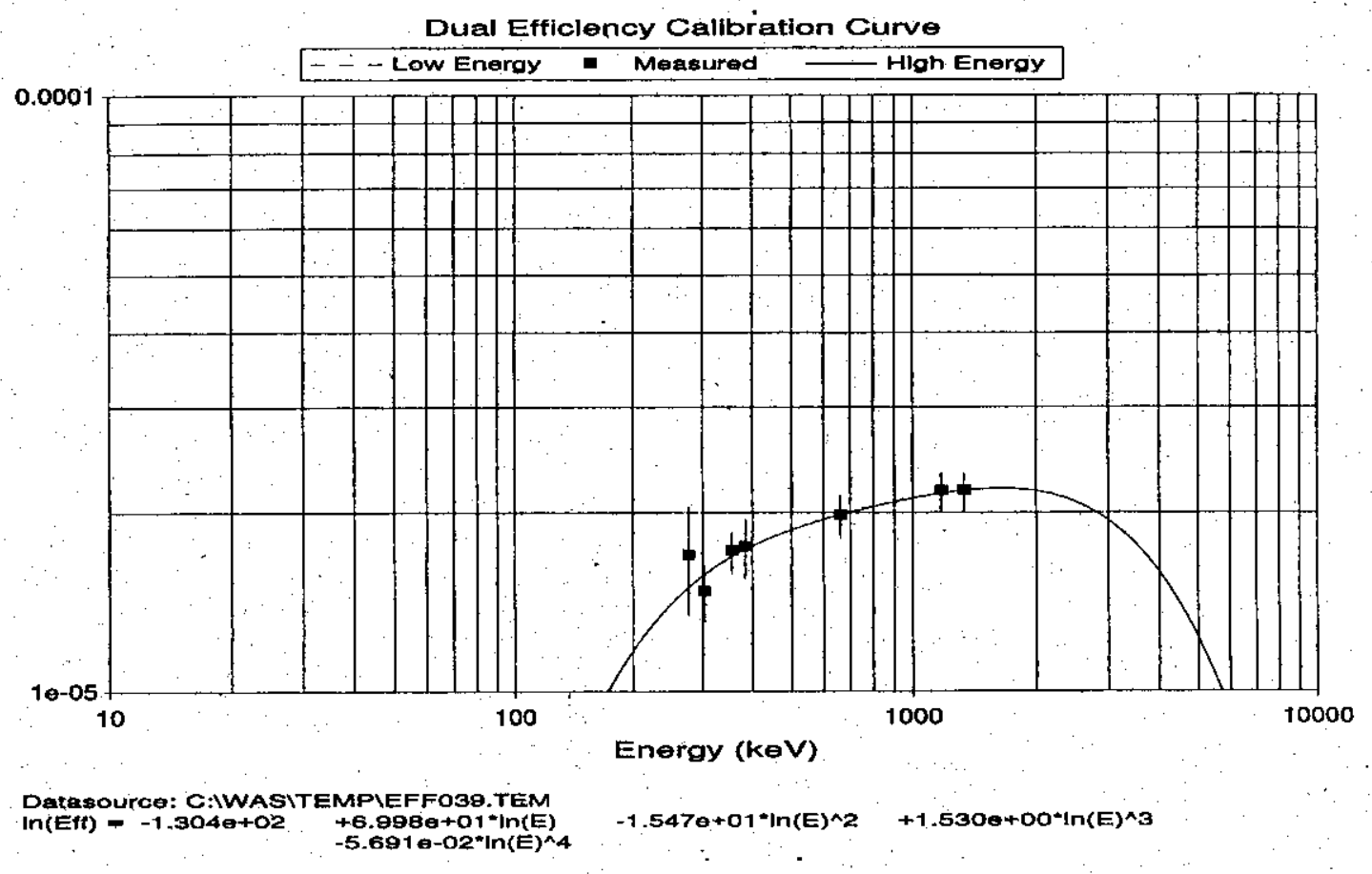

Seg 7, SEGe 2, Drum position 1. 
HNF-5148, Rev. 2

Sand Drum, density $=1.5601 \mathrm{gms} / \mathrm{cc}$ Shield (collimator). Spectrum Seq \# 3990

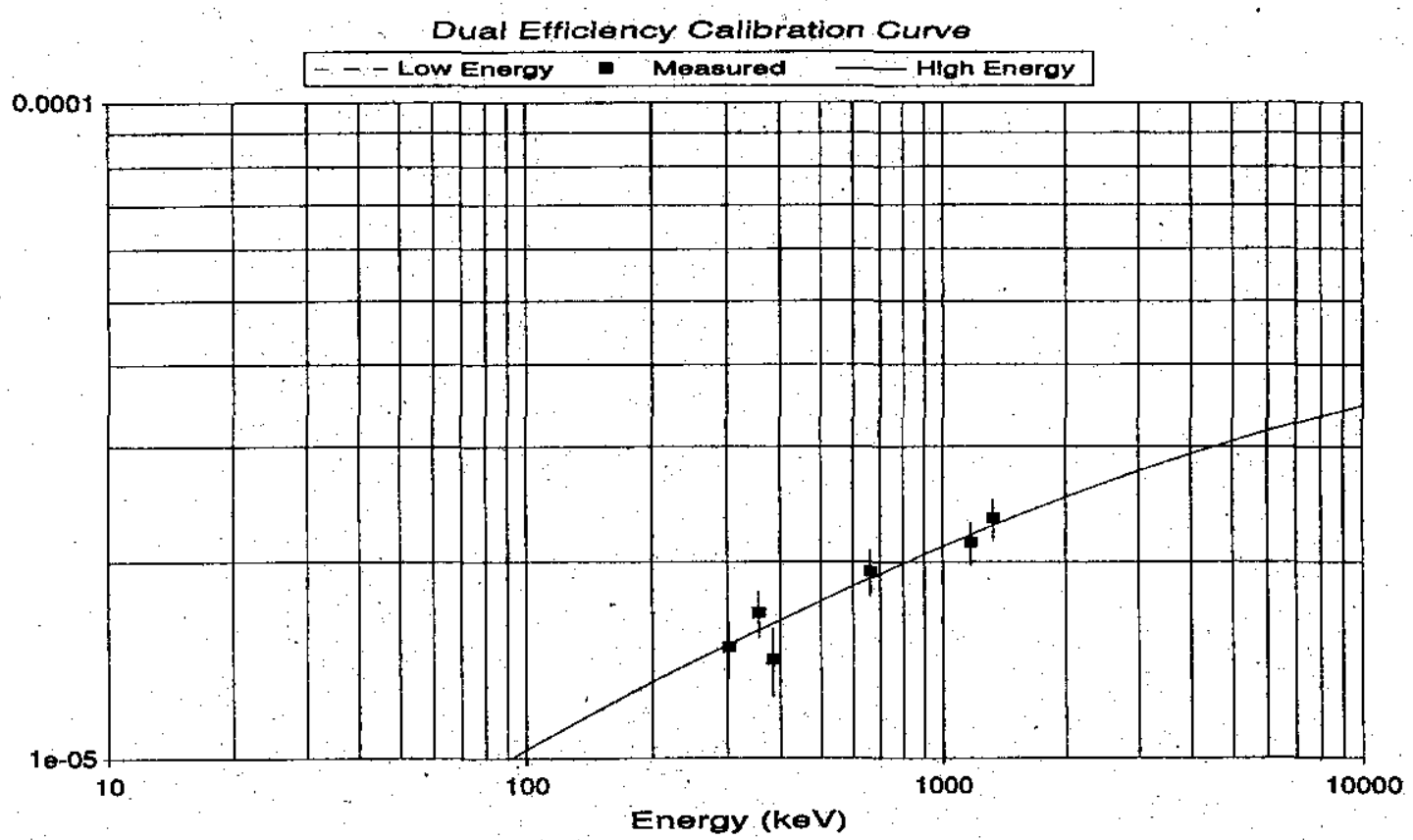

Datasource: C:IWASTTEMPIEFFO39.TEM $\ln (E f f)=-1.3570+01+5.4810-01{ }^{\circ} \ln (E)$

$-2.0639-02=\operatorname{In}(E)^{\wedge} 2$

Seg 8, SEGe 2, Drum position 2.

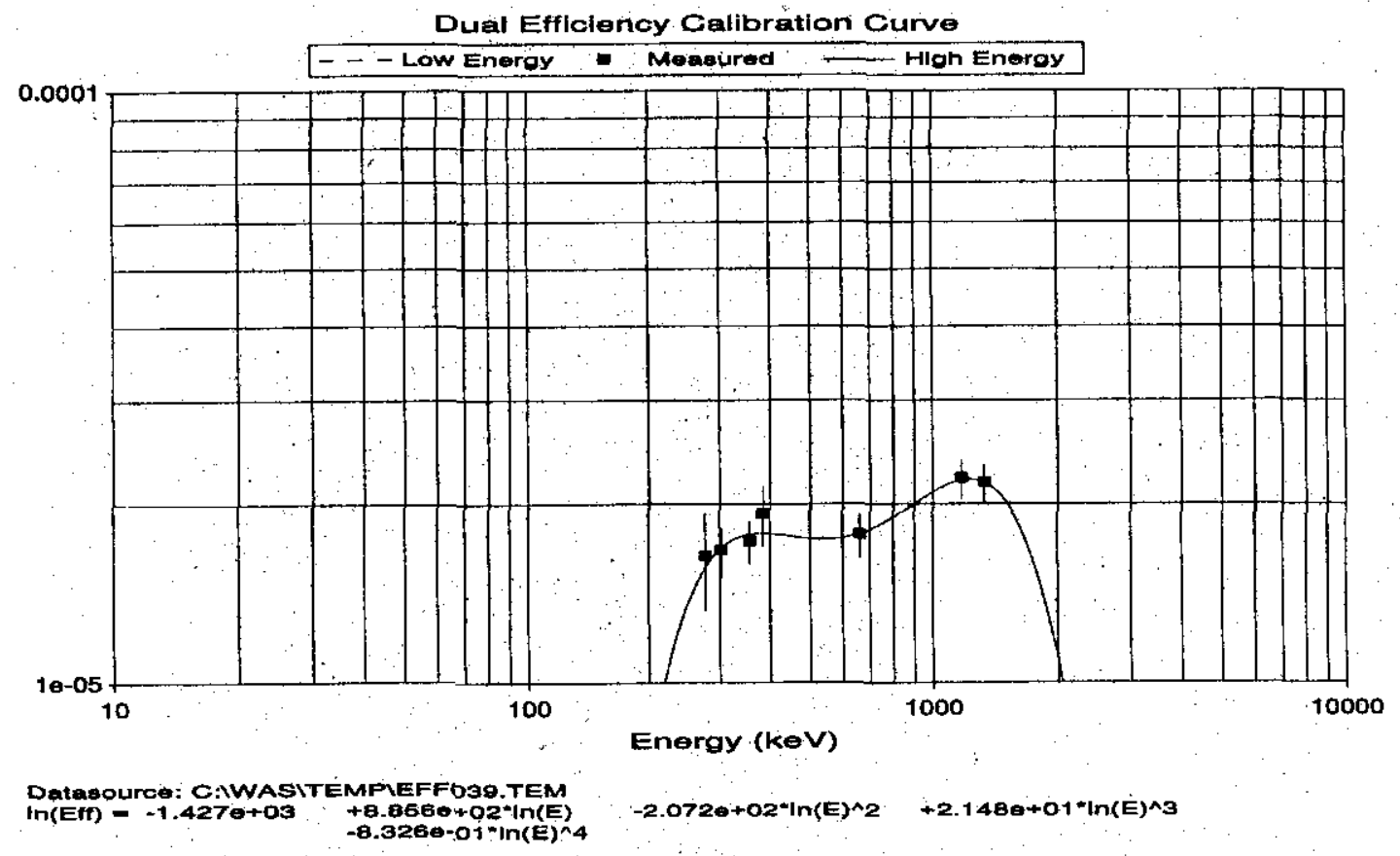

Seg 9, SEGe 2, Drum position 3. 
HNF-5148, Rev. 2

Sand Drum, density $=1.5601$ gms/cc Shield (collimator). Spectrum Seq \# 3990

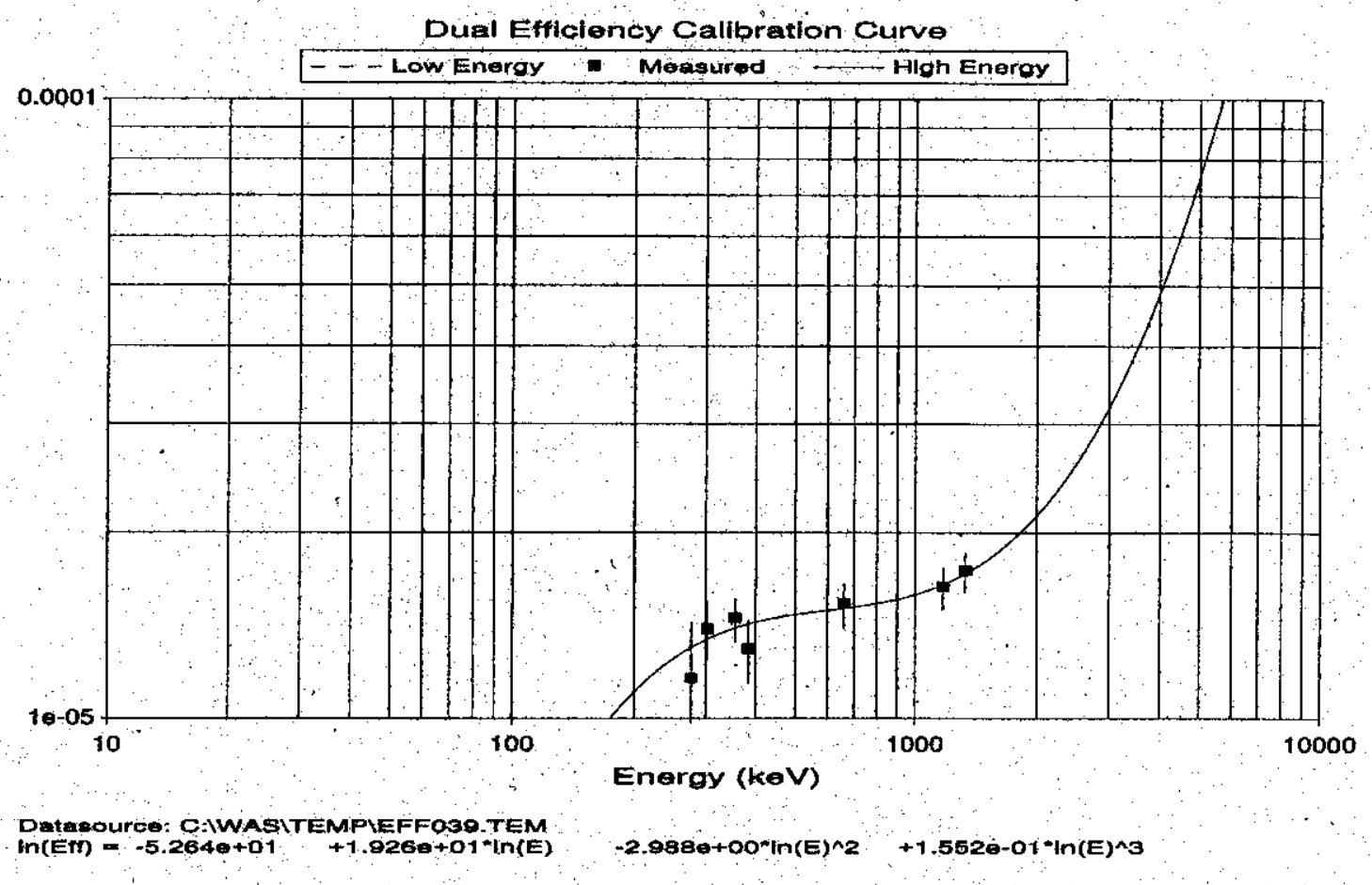

Seg 10, SEGe 1, Drum position 1.

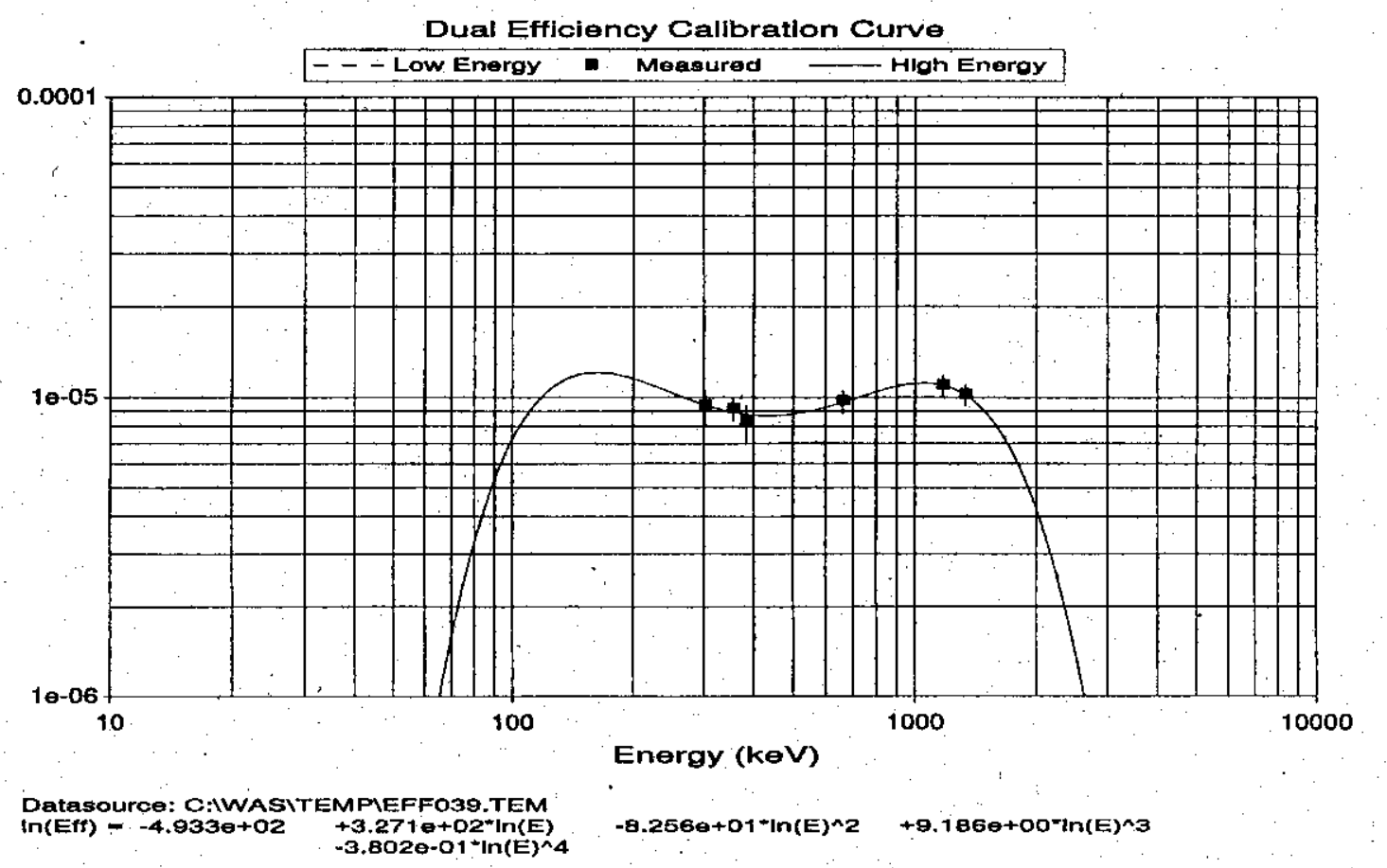

Seg 11, SEGe 1, Drum position 2. 
HNF-5148, Rev. 2

Sand Drum, density $=1.5601 \mathrm{gms} / \mathrm{cc}$ Shield (collimator). Spectrum Seq \# 3990

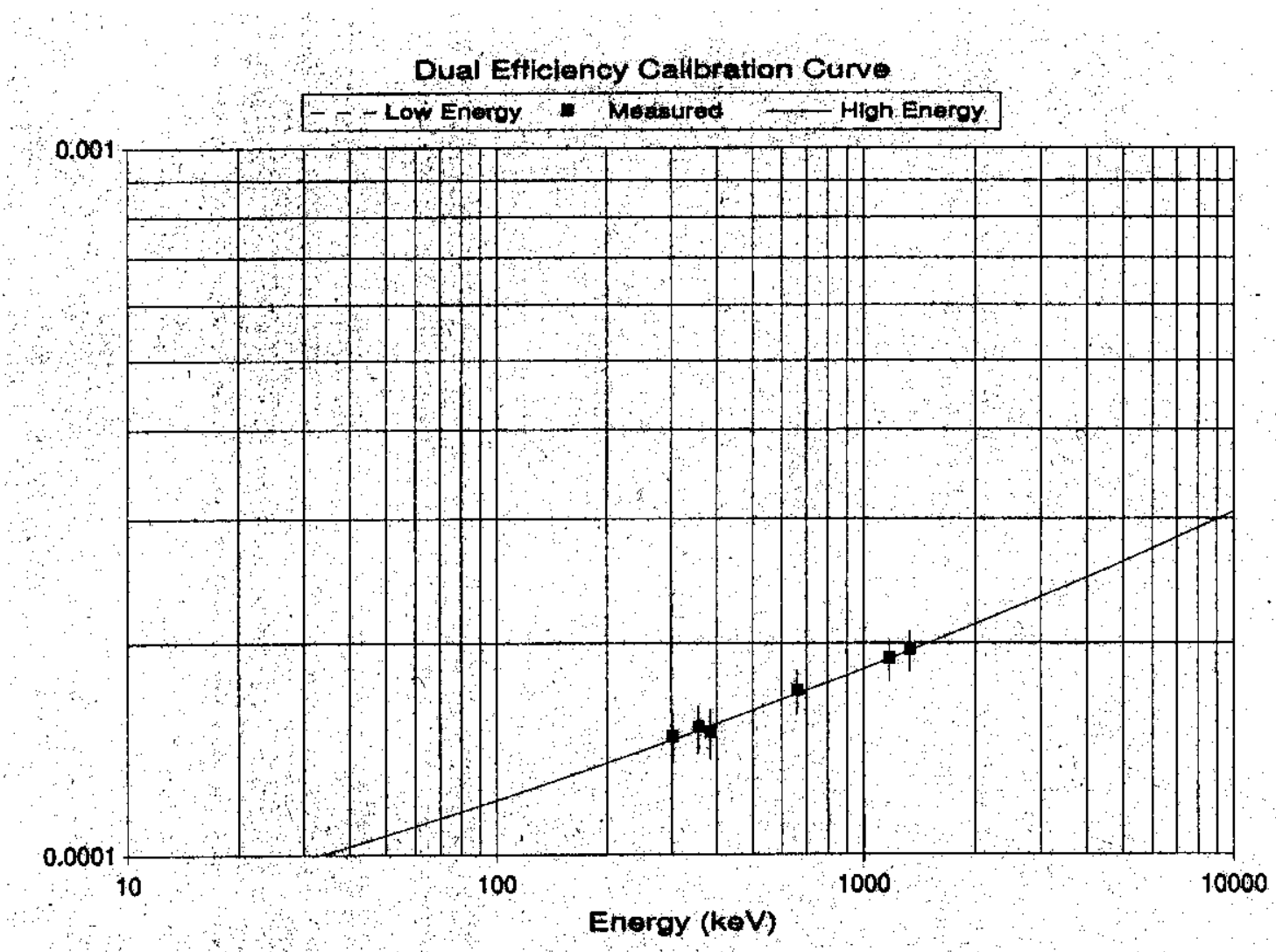

Datasourco: CAWASITENPUEF FOS9 TEM $\ln (E f)=-9.650+00+1.002 \theta-01 \ln (t)$

$+7.5680-03 * \ln (E) \wedge 2$ 
HNF-5148, Rev. 2

Summed Spectra, low density, 0.0135 , no shield.

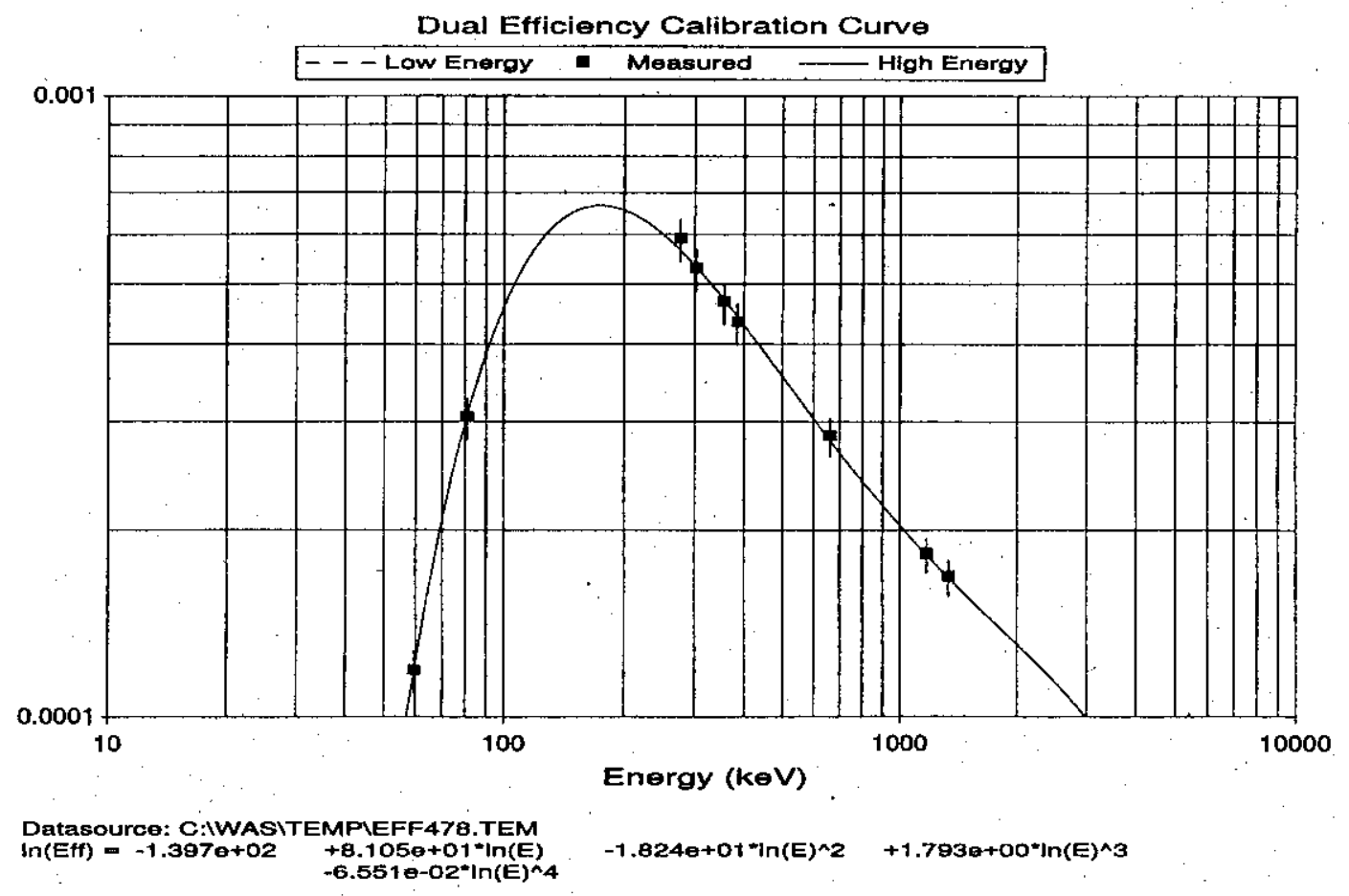

Summed Spectra, $2^{\text {nd }}$ density, 0.430 , no shield.

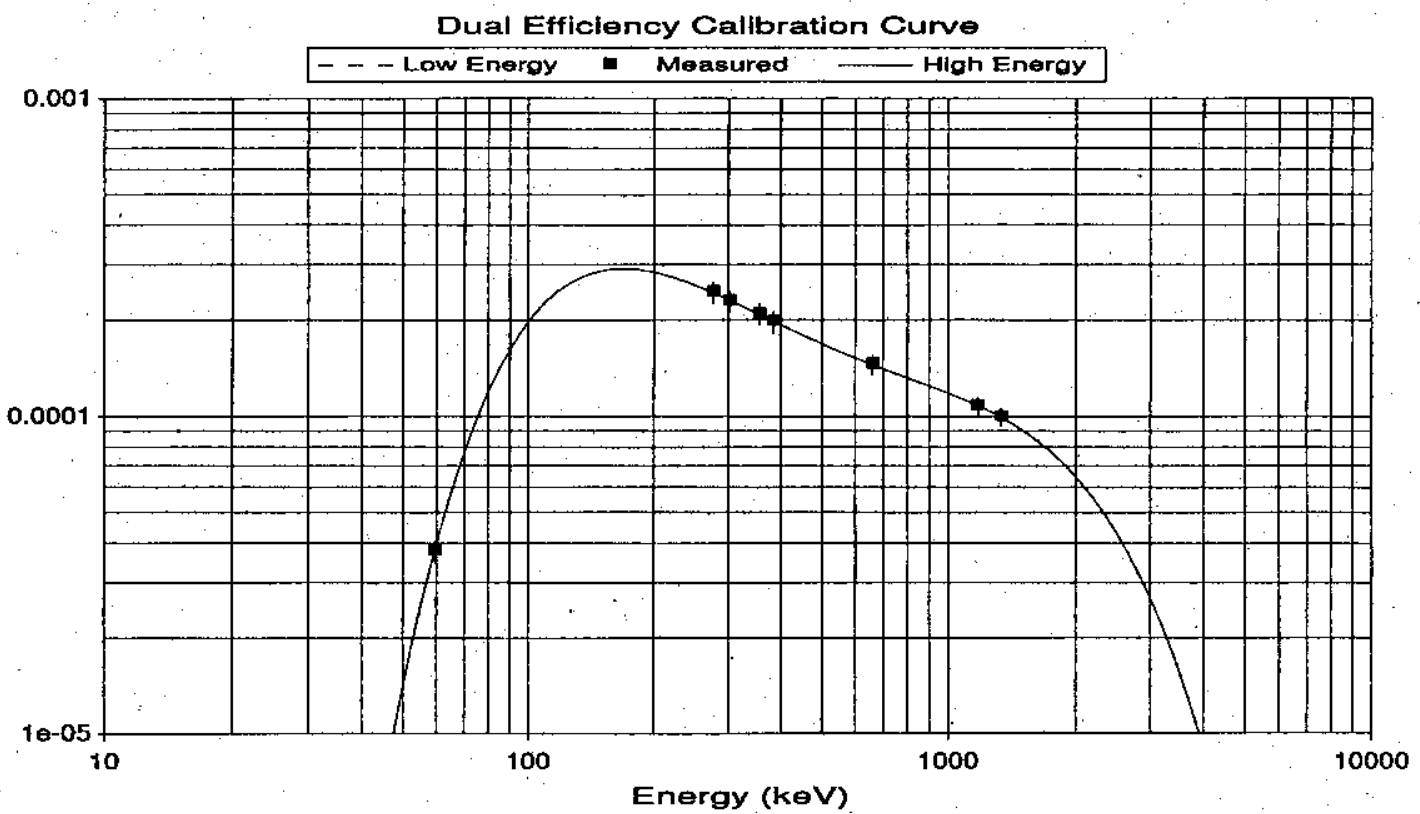

Datasource: C:IWASITEMPIEFF478.TEM $\ln (E f f)=-2.2600+02 \quad+1.4170+02^{*} \ln (E)$

$-3.423 \theta+01 * \ln (E)^{\wedge} 2 \quad+3.644 \theta+00^{*} \ln (E)^{\wedge} 3$ 
Summed Spectra, $3^{\text {rd }}$ density, 0.656 , no shield.

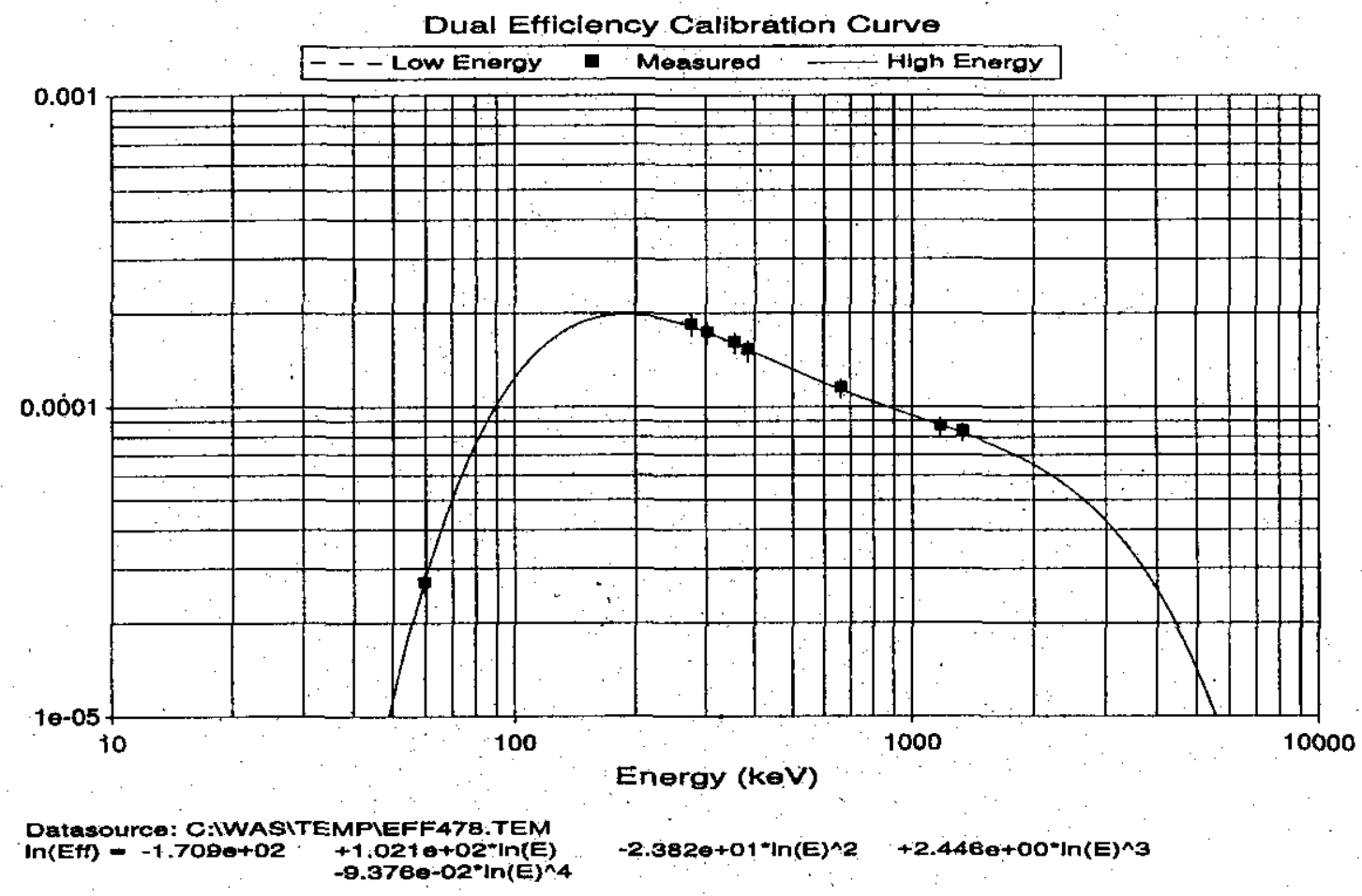

Summed Spectra, heavy density, 1.56 , no shield.

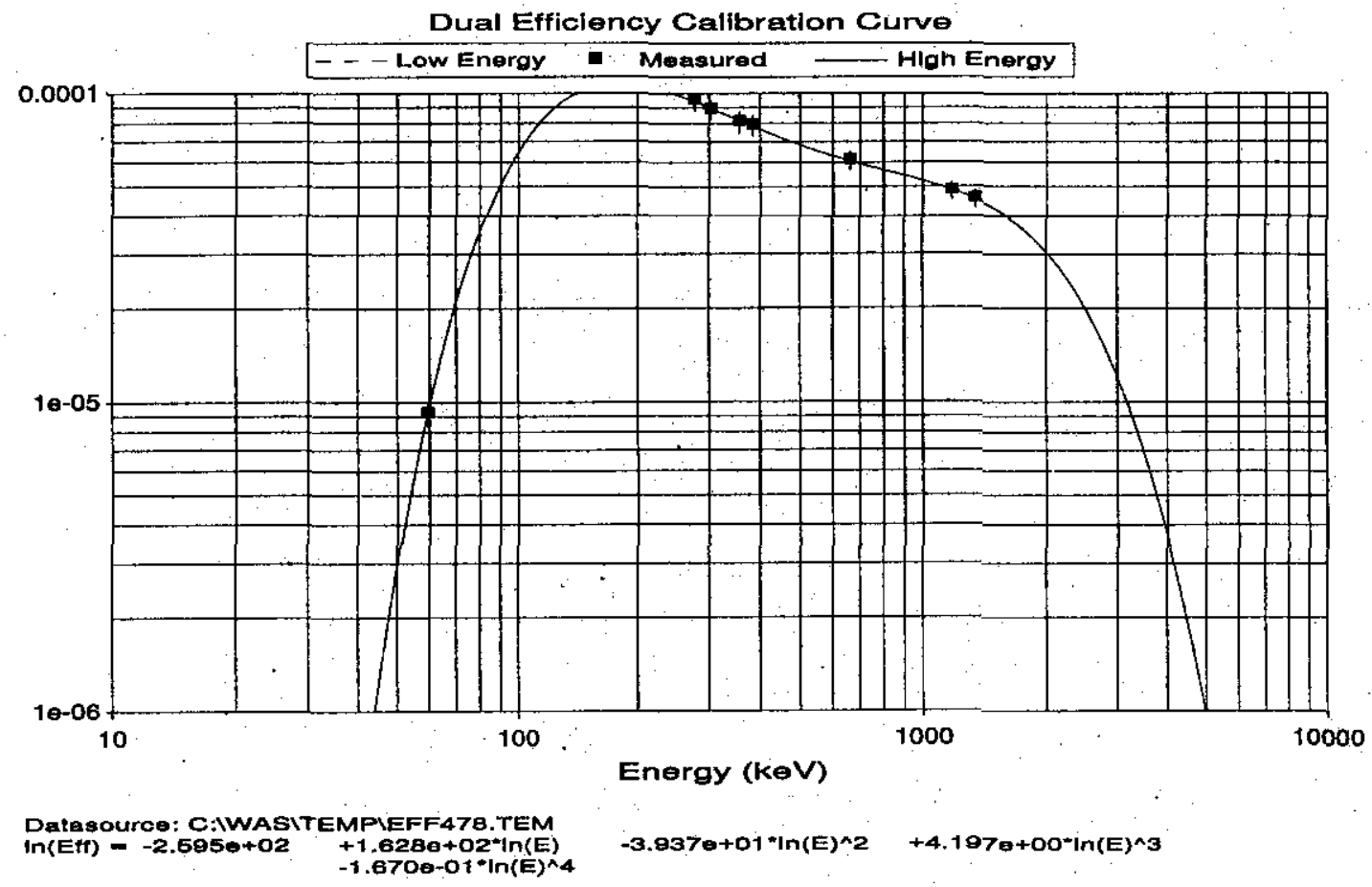


HNF-5148, Rev. 2

\section{APPENDIX F}

\section{Spreadsheets}


HNF-5148, Rev. 2

\section{Spreadsheet for Figure 2}

\begin{tabular}{|c|c|c|c|c|c|c|c|c|c|}
\hline \multirow[b]{2}{*}{ Seg\# } & \multicolumn{9}{|c|}{ COUNTS } \\
\hline & Seg & 4106 & 4107 & 4108 & 4109 & 4110 & AVG & Dev & $\%$ err \\
\hline 11-Top & $\mathrm{S} 12$ & 4542 & 4583 & 4537 & 4331 & 4617 & 4522.0 & 111.64 & 2.47 \\
\hline 10 & $\mathrm{~S} 13$ & 6777 & 6588 & 6669 & 9834 & 6678 & 7309.2 & 1413.00 & 19.33 \\
\hline 9 & S21 & 7964 & 8149 & 8377 & 8470 & 8370 & 8266.0 & 205.94 & 2.49 \\
\hline 8 & $\mathrm{~S} 22$ & 7992 & 8244 & 7991 & 8124 & 8320 & 8134.2 & 147.82 & 1.82 \\
\hline 7 & $\mathrm{~S} 23$ & 8686 & 8591 & 8359 & 8416 & 8572 & 8524.8 & 134.09 & 1.57 \\
\hline 6 & S31 & 7949 & 8185 & 8197 & 8296 & 8269 & 8179.2 & 136.98 & 1.67 \\
\hline 5 & $\mathrm{~S} 32$ & 7504 & 7763 & 7784 & 7625 & 7416 & 7618.4 & 160.02 & 2.10 \\
\hline 4 & S33 & 7134 & 7406 & 7283 & 6855 & 7064 & 7148.4 & 210.88 & 2.95 \\
\hline 3 & $\mathrm{~S} 41$ & 5330 & 5732 & 5591 & 5716 & 5701 & 5614.0 & 168.14 & 2.99 \\
\hline 2 & $\mathrm{~S} 42$ & 3138 & 3322 & 3358 & 3273 & 3209 & 3260.0 & 88.18 & 2.70 \\
\hline A04 & & 69025 & 69620 & 70322 & 70768 & 70642 & 70075.4 & 736.93 & 1.05 \\
\hline Sum & & 67016 & 68563 & 68146 & 70940 & 68216 & 68576.2 & & \\
\hline$\%$ Diff & & 2.91 & 1.52 & 3.09 & -0.24 & 3.43 & 2.14 & & \\
\hline
\end{tabular}

\section{ACTIVITY}

\begin{tabular}{|c|c|c|c|c|c|c|c|c|c|}
\hline \multirow[b]{2}{*}{ Seg \# } & \multicolumn{2}{|c|}{$59 \mathrm{k}^{+} \mathrm{eV}$} & \multicolumn{3}{|c|}{ Sequence number } & \multirow[b]{2}{*}{4110} & \multirow[b]{2}{*}{ AVG } & \multirow[b]{2}{*}{ Dev } & \multirow[b]{2}{*}{$\%$ еп } \\
\hline & Seg & 4106 & 4107 & 4108 & 4109 & & & & \\
\hline 11 & $\mathrm{~S} 12$ & 4.034 & 4.076 & 4.036 & 3.853 & 4.106 & 4.021 & 0.10 & 2.46 \\
\hline 10 & $\mathrm{~S} 13$ & 3.765 & 3.660 & 3.705 & 3.797 & 3.711 & 3.728 & 0.05 & 1.44 \\
\hline 9 & $\mathrm{~S} 21$ & 3.634 & 3.717 & 3.821 & 3.864 & 3.819 & 3.771 & 0.09 & 2.49 \\
\hline 8 & S22 & 3.831 & 3.952 & 3.831 & 3.895 & 3.988 & 3.899 & 0.07 & 1.82 \\
\hline 7 & S23 & 3.564 & 3.525 & 3.430 & 3.453 & 3.517 & 3.498 & 0.06 & 1.58 \\
\hline 6 & S31 & 3.512 & 3.616 & 3.621 & 3.665 & 3.653 & 3.613 & 0.06 & 1.67 \\
\hline 5 & S32 & 3.761 & 3.891 & 3.901 & 3.822 & 3.717 & 3.818 & 0.08 & 2.10 \\
\hline 4 & S33 & 3.794 & 3.938 & 3.873 & 3.645 & 3.756 & 3.801 & 0.11 & 2.95 \\
\hline 3 & S41 & 3.275 & 3.522 & 3.436 & 3.512 & 3.503 & 3.449 & 0.10 & 3.00 \\
\hline 2 & $\mathrm{~S} 42$ & 3.404 & 3.603 & 3.642 & 3.550 & 3.481 & 3.536 & 0.10 & 2.70 \\
\hline A04 & & 36.707 & 37.024 & 37.398 & 37.635 & 37.568 & 37.266 & 0.39 & 1.05 \\
\hline Sum & & 36.573 & 37.501 & 37.297 & 37.055 & 37.251 & 37.135 & & \\
\hline$\%$ Diff & & 0.37 & -1.29 & 0.27 & 1.54 & 0.84 & 0.35 & & \\
\hline
\end{tabular}


HNF-5148, Rev. 2

Activity and Count response for $1-2000 \mathrm{cal}$

Daily Source Drum

COUNTS

\begin{tabular}{|c|c|c|c|c|c|c|c|c|c|}
\hline \multirow[b]{2}{*}{ Seg \# } & \multicolumn{2}{|c|}{$81 \mathrm{keV}$} & \multicolumn{3}{|c|}{ Sequence number } & \multirow[b]{2}{*}{4110} & \multirow[b]{2}{*}{ AVG } & \multirow[b]{2}{*}{ Dev } & \multirow[b]{2}{*}{$\%$ err } \\
\hline & Seg & 4106 & 4107 & 4108 & 4109 & & & & \\
\hline 11-Top & S12 & 12013 & 11293 & 12379 & 12377 & 11693 & 11951.0 & 465.84 & 3.90 \\
\hline 10 & $\mathrm{~S} 13$ & 18923 & 18848 & 18870 & 18727 & 19251 & 18923.8 & 196.49 & 1.04 \\
\hline 9 & $\mathrm{~S} 21$ & 19042 & 22199 & 18865 & 20424 & 18564 & 19818.8 & 1509.91 & 7.62 \\
\hline 8 & $\mathrm{~S} 22$ & 19992 & 20528 & 19281 & 21952 & 22377 & 20826.0 & 1308.13 & 6.28 \\
\hline 7 & $\mathrm{~S} 23$ & 18957 & 20505 & 20621 & 20572 & 19577 & 20046.4 & 745.63 & 3.72 \\
\hline 6 & S31 & 19310 & 19039 & 19336 & 18760 & 19429 & · $\quad 19174.8$ & 273.58 & 1.43 \\
\hline 5 & $\mathbf{S} 32$ & 18497 & 18676 & 18039 & 18786 & 18423 & 18484.2 & 287.22 & 1.55 \\
\hline 4 & $\$ 33$ & 16774 & 17488 & 17278 & 17679 & 17312 & 17306.2 & 337.67 & 1.95 \\
\hline 3 & $\mathrm{~S} 41$ & 13183 & 11923 & 15999 & 16188 & 11539 & 13766.4 & 2210.68 & 16.06 \\
\hline 2 & $\mathrm{~S} 42$ & 7167 & 9236 & 9220 & 9042 & 7973 & 8527.6 & 922.59 & 10.82 \\
\hline A04 & & 149800 & 115291 & 150812 & 151217 & 151793 & 143782.6 & 15943.88 & 11.09 \\
\hline Sum & & 163858 & 169735 & 169888 & 174507 & 166138 & 168825.2 & & \\
\hline$\%$ Diff & & -9.38 & -47.22 & -12.65 & -15.40 & -9.45 & -17.42 & & \\
\hline
\end{tabular}

ACTIVITY

\begin{tabular}{|c|c|c|c|c|c|c|c|c|c|}
\hline \multirow[b]{2}{*}{ Seg \# } & \multicolumn{2}{|c|}{$81 \mathrm{keV}$} & \multicolumn{3}{|c|}{ Sequence number } & \multirow[b]{2}{*}{4110} & \multirow[b]{2}{*}{ AVG } & \multirow[b]{2}{*}{ Dev } & \multirow[b]{2}{*}{$\%$ err } \\
\hline & Seg & 4106 & 4107 & 4108 & 4109 & & & & \\
\hline 11 & $\mathrm{~S} \perp 2$ & 4.483 & 4.214 & 4.620 & 4.619 & 4.363 & 4.460 & 0.17 & 3.90 \\
\hline 10 & $\mathrm{~S} 13$ & 3.579 & 3.565 & 3.569 & 3.542 & 3.641 & 3.579 & 0.04 & 1.04 \\
\hline 9 & $\mathrm{~S} 21$ & 2.899 & 3.380 & 2.872 & 3.109 & 2.827 & 3.017 & 0.23 & 7.61 \\
\hline 8 & $\mathrm{~S} 22$ & 3.395 & 3.486 & 3.274 & 3.728 & 3.800 & 3.537 & 0.22 & 6.28 \\
\hline 7 & $\mathrm{~S} 23$ & 3.152 & 3.410 & 3.429 & 3.412 & 3.256 & 3.332 & 0.12 & 3.68 \\
\hline 6 & S31 & 3.476 & 3.427 & 3.480 & 3.376 & 3.497 & 3.451 & 0.05 & 1.43 \\
\hline 5 & $\mathrm{~S} 32$ & 3.522 & 3.556 & 3.435 & 3.577 & 3.508 & 3.520 & 0.05 & 1.55 \\
\hline 4 & $\mathrm{~S} 33$ & 3.196 & 3.332 & 3.292 & 3.368 & 3.298 & 3.297 & 0.06 & 1.95 \\
\hline 3 & S41 & 2.996 & 2.710 & 3.637 & 3.680 & 2.623 & 3.129 & 0.50 & 16.06 \\
\hline 2 & $\mathrm{~S} 42$ & 3.019 & 3.891 & 3.884 & 3.809 & 3.359 & 3.592 & 0.39 & 10.82 \\
\hline A04 & & 34.010 & 34.349 & 34.240 & 34.332 & 34.463 & 34.279 & 0.17 & 0.50 \\
\hline Sum & & 33.717 & 34.970 & 35.492 & 36.220 & 34.171 & 34.914 & & \\
\hline$\%$ Diff & & 0.86 & -1.81 & -3.66 & -5.50 & 0.85 & -1.85 & & \\
\hline
\end{tabular}


HNF-5148, Rev. 2

Activity and Count response for 1-2000 cal

Daily Source Drum

\begin{tabular}{|c|c|c|c|c|c|c|c|c|c|}
\hline \multirow[b]{3}{*}{ Seg \# } & \multicolumn{9}{|c|}{ COUNTS } \\
\hline & & $356 \mathrm{keV}$ & & Sequence & number & & & & \\
\hline & Seg & 4106 & 4107 & 4108 & 4109 & 4110 & $\mathrm{AVG}$ & Dev & $\%$ err \\
\hline 11-Top & $\mathrm{S} 12$ & 25224 & 25856 & 25486 & 25891 & 25730 & 25637.4 & 280.4 & 1.09 \\
\hline 10 & $\mathrm{~S} 13$ & 38324 & 39185 & 38780 & 38893 & 38746 & 38785.6 & 310.5 & 0.80 \\
\hline 9 & $\mathrm{~S} 21$ & 43236 & 42259 & 43578 & 43350 & 43331 & 43150.8 & 514.1 & 1.19 \\
\hline 8 & $\mathrm{~S} 22$ & 43600 & 43748 & 43871 & 44066 & 44089 & 43874.8 & 208.6 & 0.48 \\
\hline 7 & $\mathrm{~S} 23$ & 44396 & 43356 & 44099 & 44096 & 43949 & 43979.2 & 384.4 & 0.87 \\
\hline 6 & $\mathrm{~S} 31$ & 46295 & 46896 & 46348 & 46799 & 47071 & 46681.8 & 343.6 & 0.74 \\
\hline 5 & $\mathrm{~S} 32$ & 46082 & 45829 & 45734 & 46506 & 45967 & 46023.6 & 300.4 & 0.65 \\
\hline 4 & S33 & 43308 & 43777 & 43397 & 43272 & 43427 & 43436.2 & 200.7 & 0.46 \\
\hline 3 & $\mathrm{~S} 41$ & 32772 & 33185 & 32852 & 32872 & 32803 & 32896.8 & 165.9 & 0.50 \\
\hline 2 & $\mathrm{~S} 42$ & 19447 & 19879 & 19622 & 19376 & 19497 & 19564.2 & 197.6 & 1.01 \\
\hline A04 & & 382713 & 385298 & 383730 & 385822 & 386017 & 384716 & 1435.2 & 0.37 \\
\hline Sum & & 382684 & 383970 & 383767 & 385121 & 384610 & 384030.4 & & \\
\hline Diff & & 0.01 & 0.34 & -0.01 & 0.18 & 0.36 & 0.18 & & \\
\hline
\end{tabular}

\section{ACTIVITY}

\begin{tabular}{|c|c|c|c|c|c|c|c|c|c|}
\hline \multirow[b]{2}{*}{ Seg \# } & \multicolumn{2}{|r|}{$356 \mathrm{keV}$} & \multicolumn{3}{|c|}{ Sequence number } & \multirow[b]{2}{*}{4110} & \multirow[b]{2}{*}{ AVG } & \multirow[b]{2}{*}{ Dev } & \multirow[b]{2}{*}{$\%$ err } \\
\hline & Seg & 4106 & 4107 & 4108 & 4109 & & & & \\
\hline 11 & $\mathrm{~S} 12$ & 3.080 & 3.157 & 3.113 & 3.162 & 3.142 & 3.131 & 0.034 & 1.09 \\
\hline 10 & $\mathrm{~S} 13$ & 3.045 & 3.113 & 3.081 & 3.090 & 3.078 & 3.082 & 0.025 & 0.80 \\
\hline 9 & $\mathrm{~S} 21$ & 3.139 & 3.141 & 3.164 & 3.148 & 3.146 & 3.148 & 0.010 & 0.31 \\
\hline 8 & $\mathrm{~S} 22$ & 3.104 & 3.114 & 3.124 & 3.137 & 3.139 & 3.124 & 0.015 & 0.48 \\
\hline 7 & S23 & 3.161 & 3.087 & 3.140 & 3.140 & 3.130 & 3.132 & 0.027 & 0.87 \\
\hline 6 & S31 & 3.118 & 3.159 & 3.122 & 3.152 & 3.171 & 3.144 & 0.023 & 0.73 \\
\hline 5 & $\mathrm{~S} 32$ & 3.186 & 3.168 & 3.162 & 3.215 & 3.178 & 3.182 & 0.021 & 0.65 \\
\hline 4 & $\mathrm{~S} 33$ & 3.099 & 3.133 & 3.106 & 3.097 & 3.108 & 3.108 & 0.014 & 0.46 \\
\hline 3 & S41 & 3.149 & 3.189 & 3.157 & 3.159 & 3.152 & 3.161 & 0.016 & 0.51 \\
\hline 2 & $\mathrm{~S} 42$ & 3.206 & 3.277 & 3.235 & 3.193 & 3.214 & 3.225 & 0.033 & 1.02 \\
\hline A04 & & 31.944 & 32.160 & 32.030 & 32.204 & 32.221 & 32.112 & 0.120 & 0.37 \\
\hline Sum & & 31.288 & 31.540 & 31.404 & 31.492 & 31.458 & 31.436 & & \\
\hline$\%$ Diff & & 2.05 & 1.93 & 1.95 & 2.21 & 2.37 & 2.10 & & \\
\hline
\end{tabular}


HNF-5148, Rev. 2

Activity and Count response for $1-2000 \mathrm{cal}$

Daily Source Drum

\begin{tabular}{|c|c|c|c|c|c|c|c|c|c|}
\hline \multirow[b]{3}{*}{ Seg \# } & \multicolumn{9}{|c|}{ COUNTS } \\
\hline & \multicolumn{2}{|c|}{$661 \mathrm{keV}$} & \multicolumn{3}{|c|}{ Sequence number } & \multirow[b]{2}{*}{4110} & \multirow[b]{2}{*}{ AVG } & \multirow[b]{2}{*}{ Dev } & \multirow[b]{2}{*}{$\%$ err } \\
\hline & Seg & 4106 & 4107 & 4108 & 4109 & & & & \\
\hline 11 -Top & $\mathrm{S} 12$ & 4062 & 4026 & 3939 & 3922 & 3983 & 3986.4 & 58.50 & 1.47 \\
\hline 10 & $\mathrm{~S} 13$ & 5767 & 5929 & 6034 & 6082 & 5894 & 5941.2 & 123.65 & 2.08 \\
\hline 9 & $\mathrm{~S} 21$ & 6856 & 6646 & 6685 & 6695 & 6719 & 6720.2 & 80.35 & 1.20 \\
\hline 8 & $\mathrm{~S} 22$ & 6873 & 6657 & 6908 & 6733 & 6641 & 6762.4 & 122.62 & 1.81 \\
\hline 7 & $\mathrm{~S} 23$ & 6936 & 6945 & 6769 & 6850 & 6845 & 6869.0 & 72.80 & 1.06 \\
\hline 6 & S31 & 7308 & 7204 & 7178 & 7225 & 7250 & 7233.0 & 49.61 & 0.69 \\
\hline 5 & $\mathrm{~S} 32$ & 7323 & 7143 & 7162 & 7121 & 7291 & 7208.0 & 92.23 & 1.28 \\
\hline 4 & S33 & 6624 & 6741 & 6815 & 6914 & 6799 & 6778.6 & 106.52 & 1.57 \\
\hline 3 & $S 41$ & 4957 & 5035 & 4980 & 5032 & 5024 & 5005.6 & 35.06 & 0.70 \\
\hline 2 & $\mathrm{~S} 42$ & 2991 & 2943 & 3046 & 3061 & 3021 & 3012.4 & 47.01 & 1.56 \\
\hline A04 & & 59842 & 59656 & 59766 & 59750 & 59553 & 59713.4 & 111.43 & 0.19 \\
\hline Sum & & 59697 & 59269 & 59516 & 59635 & 59467 & 59516.8 & & \\
\hline$\%$ Diff & & 0.24 & 0.65 & 0.42 & 0.19 & 0.14 & 0.33 & & \\
\hline
\end{tabular}

ACTIVITY

\begin{tabular}{|c|c|c|c|c|c|c|c|c|c|}
\hline \multirow[b]{2}{*}{ Seg \# } & \multicolumn{2}{|c|}{$661 \mathrm{keV}$} & \multicolumn{3}{|c|}{ Sequence number } & \multirow[b]{2}{*}{4110} & \multirow[b]{2}{*}{$A \vee G$} & \multirow[b]{2}{*}{ Dev } & \multirow[b]{2}{*}{$\%$ err } \\
\hline & Seg & 4106 & 4107 & 4108 & 4109 & & & & \\
\hline 11 & $\mathrm{~S} 12$ & 0.589 & 0.584 & 0.572 & 0.562 & 0.578 & 0.577 & 0.011 & 1.89 \\
\hline 10 & $\mathrm{~S} 13$ & 0.531 & 0.546 & 0.556 & 0.560 & 0.543 & 0.547 & 0.011 & 2.08 \\
\hline 9 & $\mathrm{~S} 21$ & 0.575 & 0.557 & 0.560 & 0.561 & 0.563 & 0.563 & 0.007 & 1.20 \\
\hline 8 & $\mathrm{~S} 22$ & 0.589 & 0.570 & 0.592 & 0.577 & 0.569 & 0.579 & 0.010 & 1.81 \\
\hline 7 & $\mathrm{~S} 23$ & 0.575 & 0.575 & 0.561 & 0.567 & 0.567 & 0.569 & 0.006 & 1.06 \\
\hline 6 & S31 & 0.608 & 0.599 & 0.597 & 0.601 & 0.603 & 0.601 & 0.004 & 0.69 \\
\hline 5 & $\mathrm{~S} 32$ & 0.597 & 0.582 & 0.584 & 0.580 & 0.594 & 0.588 & 0.008 & 1.28 \\
\hline 4 & S33 & 0.544 & 0.553 & 0.560 & 0.568 & 0.558 & 0.557 & 0.009 & 1.57 \\
\hline 3 & $\$ 41$ & 0.557 & 0.566 & 0.560 & 0.566 & 0.565 & 0.562 & 0.004 & 0.70 \\
\hline 2 & $\mathrm{~S} 42$ & 0.562 & 0.553 & 0.573 & 0.575 & 0.568 & 0.566 & 0.009 & 1.56 \\
\hline A04 & & 5.948 & 5.929 & 5.940 & 5.939 & 5.919 & 5.935 & 0.011 & 0.19 \\
\hline Sum & & 5.726 & 5.687 & 5.713 & 5.717 & 5.708 & 5.710 & & \\
\hline$\%$ Diff & & 3.72 & 4.09 & 3.83 & 3.73 & 3.57 & 3.79 & & \\
\hline
\end{tabular}


HNF-5148, Rev. 2

Activity and Count response for 1-2000 cal

Daily Source Drum

\begin{tabular}{|c|c|c|c|c|c|c|c|c|c|}
\hline \multirow[b]{2}{*}{ Seg\# } & \multicolumn{9}{|c|}{ COUNTS } \\
\hline & Seg & 4106 & 4107 & 4108 & 4109 & 4110 & . AVG & Dev & $\%$ err \\
\hline 11-Top & $\mathrm{S} 12$ & 1966 & 1903 & 1921 & 1952 & 1894 & 1927.2 & 31.01 & 1.61 \\
\hline 10 & $\mathrm{~S} 13$ & 2780 & 2894 & 2854 & 2823 & 2879 & 2846.0 & 45.67 & 1.60 \\
\hline 9 & $\$ 21$ & 3219 & 3150 & 3196 & 3222 & 3271 & 3211.6 & 43.96 & 1.37 \\
\hline 8 & S22 & 3244 & 3263 & 3297 & 3346 & 3177 & 3265.4 & 62.80 & 1.92 \\
\hline 7 & $\mathrm{~S} 23$ & 3388 & 3339 & 3362 & 3343 & 3360 & 3358.4 & 19.40 & 0.58 \\
\hline 6 & $\mathrm{~S} 31$ & 3493 & 3448 & 3520 & 3544 & 3428 & 3486.6 & 48.41 & 1.39 \\
\hline 5 & $\mathrm{~S} 32$ & 3438 & 3356 & 3443 & 3472 & 3490 & 3439.8 & 51.46 & 1.50 \\
\hline 4 & $\$ 33$ & 3241 & 3263 & 3295 & 3197 & 3147 & 3228.6 & 57.89 & 1.79 \\
\hline 3 & $\$ 41$ & 2411 & 2310 & 2364 & 2368 & 2401 & 2370.8 & 39.62 & 1.67 \\
\hline 2 & $\mathrm{~S} 42$ & 1426 & 1449 & 1439 & 1359 & 1449 & 1424.4 & 37.76 & 2.65 \\
\hline A04 & & 28645 & 28393 & 28746 & 28562 & 28554 & 28580.0 & 130.14 & 0.46 \\
\hline Sum & & 28606 & 28375 & 28691 & 28626 & 28496 & 28558.8 & & \\
\hline$\%$ Diff & & 0.14 & 0.06 & 0.19 & -0.22 & 0.20 & 0.07 & & \\
\hline
\end{tabular}

ACTIVITY

\begin{tabular}{|c|c|c|c|c|c|c|c|c|c|}
\hline \multirow[b]{2}{*}{ Seg \# } & \multicolumn{2}{|c|}{$1332.5 \mathrm{keV}$} & \multicolumn{3}{|c|}{ Sequence number } & \multirow[b]{2}{*}{4110} & \multirow[b]{2}{*}{ AVG } & \multirow[b]{2}{*}{ Dev } & \multirow[b]{2}{*}{$\%$ err } \\
\hline & Seg & 4106 & 4107 & 4108 & 4109 & & & & \\
\hline 11 & $\mathrm{~S} 12$ & 0.4158 & 0.4024 & 0.4063 & 0.4130 & 0.4007 & 0.4076 & 0.0066 & 1.61 \\
\hline 10 & $\mathrm{~S} 13$ & 0.3647 & 0.3797 & 0.3745 & 0.3703 & 0.3777 & 0.3734 & 0.0060 & 1.61 \\
\hline 9 & $\mathrm{~S} 21$ & 0.3964 & 0.3879 & 0.3936 & 0.3968 & 0.4027 & 0.3955 & 0.0054 & 1.37 \\
\hline 8 & S22 & 0.3916 & 0.3940 & 0.3980 & 0.4040 & 0.3835 & 0.3942 & 0.0076 & 1.93 \\
\hline 7 & $\mathrm{~S} 23$ & 0.4115 & 0.4055 & 0.4083 & 0.4060 & 0.4081 & 0.4079 & 0.0024 & 0.58 \\
\hline 6 & S31 & 0.3845 & 0.3795 & 0.3874 & 0.3900 & 0.3772 & 0.3837 & 0.0053 & 1.39 \\
\hline 5 & $\mathrm{~S} 32$ & 0.4103 & 0.4006 & 0.4109 & 0.4143 & 0.4165 & 0.4105 & 0.0061 & 1.49 \\
\hline 4 & $\mathrm{~S} 33$ & 0.3899 & 0.3926 & 0.3963 & 0.3845 & 0.3786 & 0.3884 & 0.0070 & 1.79 \\
\hline 3 & $\mathrm{~S} 41$ & 0.4070 & 0.3901 & 0.3993 & 0.3998 & 0.4055 & 0.4003 & 0.0067 & 1.66 \\
\hline 2 & $\mathrm{~S} 42$ & 0.3665 & 0.3723 & 0.3699 & 0.3494 & 0.3724 & 0.3661 & 0.0096 & 2.64 \\
\hline A04 & & 4.0484 & 4.0128 & 4.0627 & 4.0366 & 4.0356 & 4.0392 & 0.0184 & 0.45 \\
\hline Sum & & 3.9382 & 3.9046 & 3.9445 & 3.9281 & 3.9231 & 3.9277 & & \\
\hline$\%$ Diff & & 2.72 & 2.70 & 2.91 & 2.69 & 2.79 & 2.76 & & \\
\hline
\end{tabular}




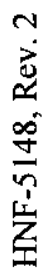

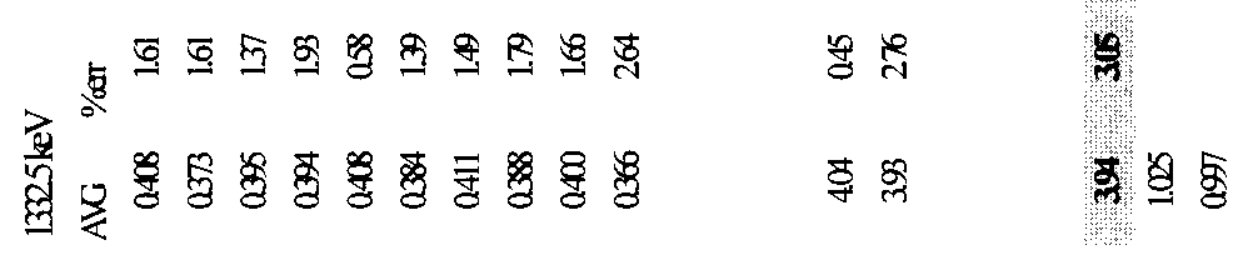

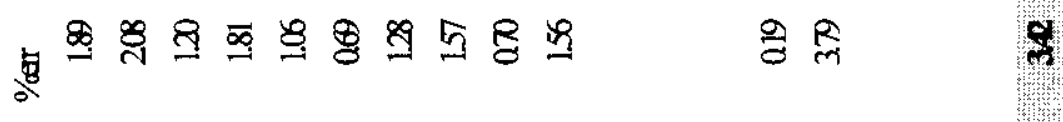

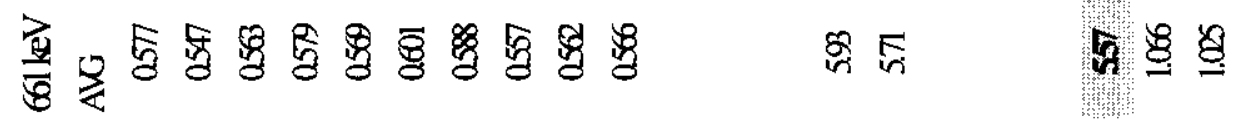

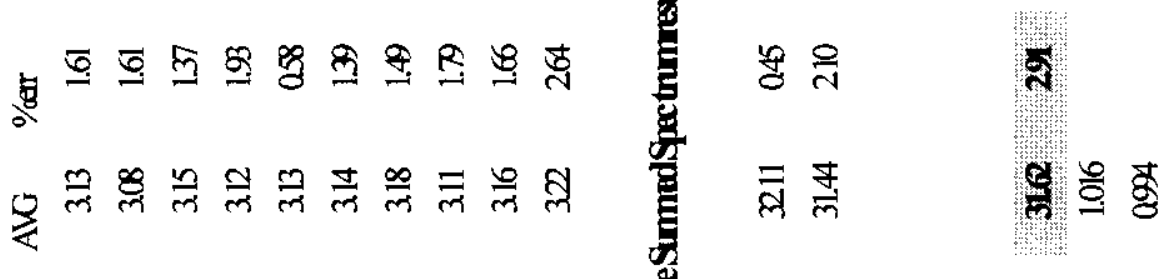

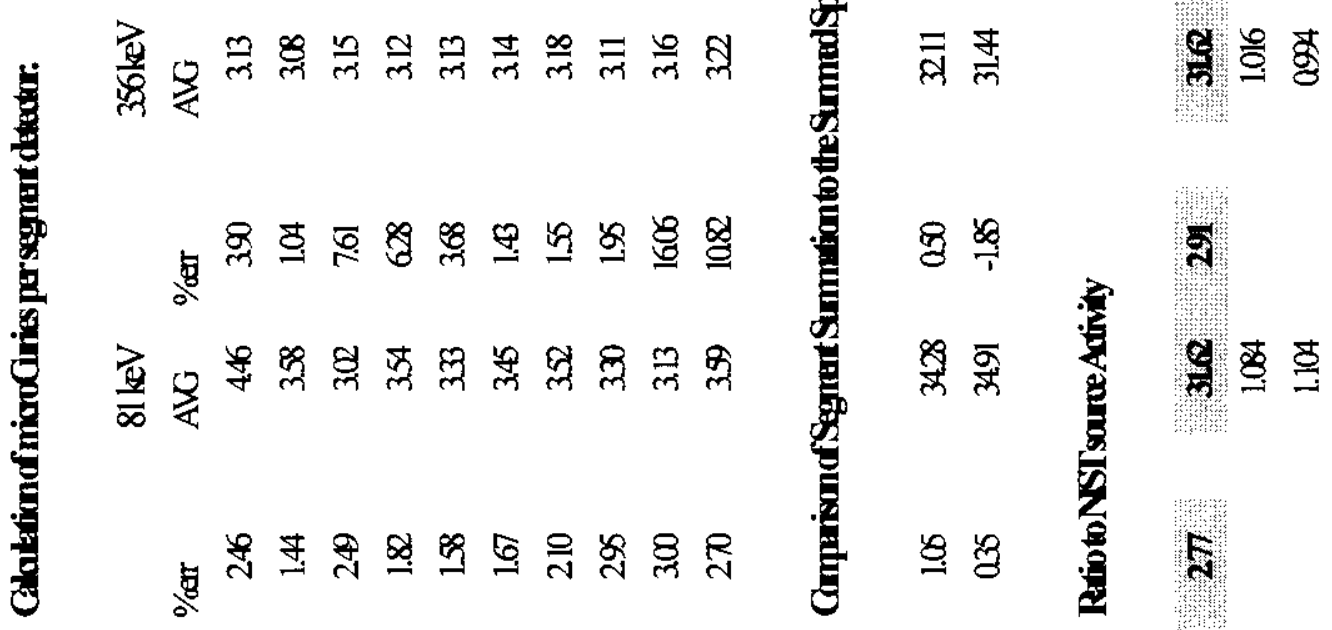

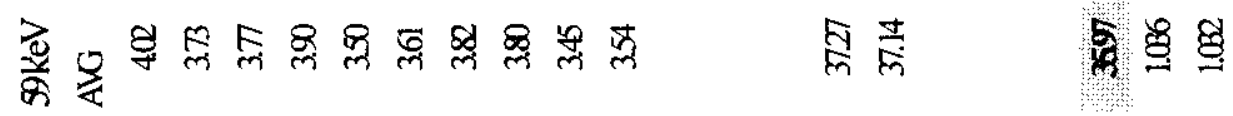

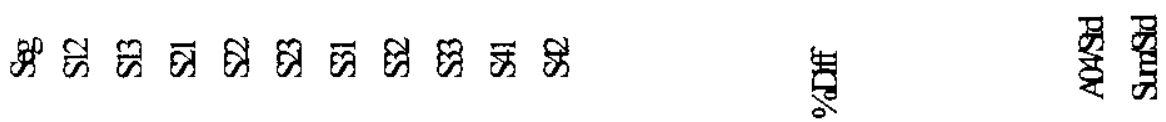

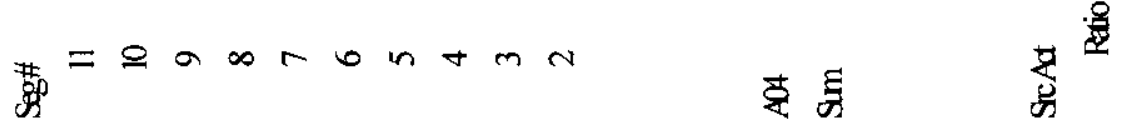


HNF-5148, Rev. 2

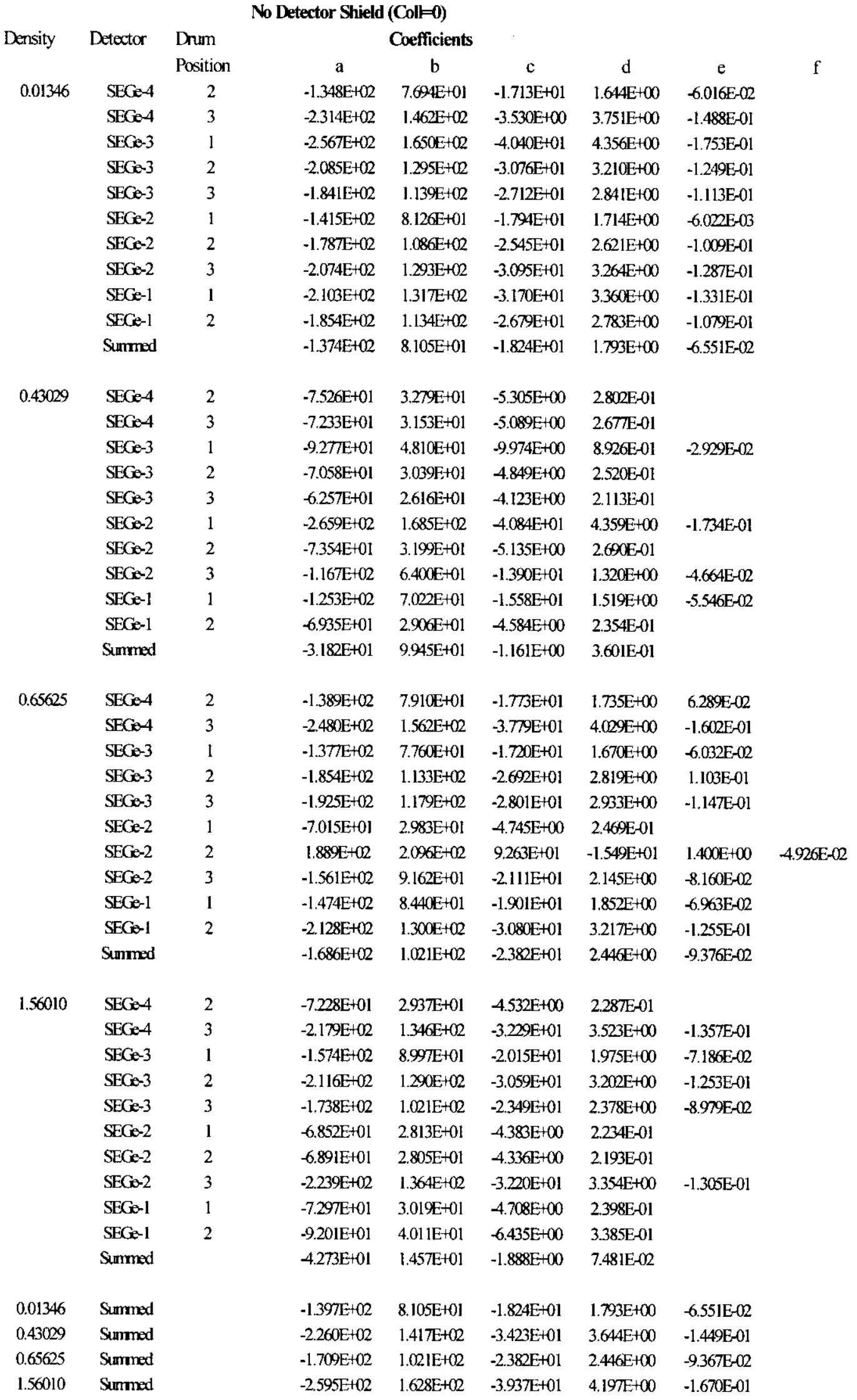


HNF-5148, Rev. 2

\begin{tabular}{|c|c|c|c|c|c|c|c|}
\hline \multirow[t]{2}{*}{ Density } & \multirow[t]{2}{*}{ Detector } & Drum & \multicolumn{3}{|c|}{ Coefficients } & \multirow[b]{2}{*}{$\mathrm{d}$} & \multirow[b]{2}{*}{$\mathrm{e}$} \\
\hline & & Position & $\mathrm{a}$ & $b$ & $\mathrm{c}$ & & \\
\hline \multirow[t]{11}{*}{0.01346} & SEGe-4 & 2 & $-6.420 \mathrm{E}+01$ & $2.566 \mathrm{E}+01$ & $-4.001 E+00$ & $2.061 \mathrm{E}-01$ & \\
\hline & SEGe-4 & 3 & $-9.956 \mathrm{E}+01$ & $4.232 \mathrm{E}+01$ & $-6.565 E+00$ & $3.365 \mathrm{E}-01$ & \\
\hline & SEGe-3 & 1 & $-5.473 \mathrm{E}+01$ & $2.092 E+01$ & $-3.175 \mathrm{E}+00$ & $1.589 \mathrm{E}-01$ & \\
\hline & SEGe-3 & 2 & $-8.927 E+01$ & $3.665 \mathrm{E}+01$ & $-5.556 \mathrm{E}+00$ & $2.786 \mathrm{E}-01$ & \\
\hline & SEGe-3 & 3 & $-2.638 \mathrm{E}+02$ & $-1.657 \mathrm{E}+02$ & $-4.030 \mathrm{E}+01$ & $4.346 \mathrm{E}+00$ & $-1.754 \mathrm{E}-01$ \\
\hline & SEGe-2 & 1 & $-5.764 \mathrm{E}+01$ & $2.261 \mathrm{E}+01$ & $-3.490 \mathrm{E}+00$ & $1.779 \mathrm{E}-01$ & \\
\hline & SEGe-2 & 2 & $-5.166 \mathrm{E}+02$ & $3.223 E+02$ & $-7.662 E+01$ & $8.080 \mathrm{E}+00$ & $-3.190 \mathrm{E}-01$ \\
\hline & SEGe-2 & 3 & $-1.893 E+01$ & $3.569 \mathrm{E}+00$ & $-3.903 \mathrm{E}-01$ & $1.070 \mathrm{E}-02$ & \\
\hline & SEGe-1 & 1 & $-4.623 \mathrm{E}+01$ & $1.693 \mathrm{E}+01$ & $-2.573 E+00$ & $1.284 \mathrm{E}-01$ & \\
\hline & SEGe-1 & 2 & $-5.738 \mathrm{E}+01$ & $3.434 \mathrm{E}+01$ & $-9.082 \mathrm{E}+00$ & $1.046 \mathrm{E}+00$ & $-4.452 \mathrm{E}-02$ \\
\hline & Summed & & $-4.043 E+01$ & $1.530 \mathrm{E}+01$ & $-2.311 \mathrm{E}+00$ & $1.147 \mathrm{E}-01$ & \\
\hline \multirow[t]{11}{*}{0.43029} & SEGe-4 & 2 & $-5.468 \mathrm{E}+0 \mathrm{l}$ & $1.913 \mathrm{E}+01$ & $-2.751 \mathrm{E}+00$ & $1.314 \mathrm{E}-01$ & \\
\hline & SEGe-4 & 3 & $-1.110 E+03$ & $6.916 \mathrm{E}+02$ & $-1.626 \mathrm{E}+02$ & $1.695 \mathrm{E}+01$ & $-6.613 E-01$ \\
\hline & SEGe-3 & 1 & $-1.527 \mathrm{E}+01$ & $1.589 \mathrm{E}+00$ & $-1.182 \mathrm{E}-01$ & & \\
\hline & SEGe-3 & 2 & $-3.973 E+02$ & $2.539 E+02$ & $-6.238 \mathrm{E}+01$ & $6.797 \mathrm{E}+00$ & $-2.770 \mathrm{E}-01$ \\
\hline & SEGe-3 & 3 & $-1.234 \mathrm{E}+02$ & $7.655 \mathrm{E}+02$ & $-1.792 \mathrm{E}+02$ & $1.861 \mathrm{E}+01$ & $-7.232 \mathrm{E}-01$ \\
\hline & SEGe-2 & 1 & $-1.959 \mathrm{E}+01$ & $2.939 \mathrm{E}+00$ & $-2.223 \mathrm{E}-01$ & & \\
\hline & SEGe-2 & 2 & $-1.993 \mathrm{E}+01$ & $3.047 \mathrm{E}+00$ & $-2.318 \mathrm{E}-01$ & & \\
\hline & SEGe-2 & 3 & $-1.602 E+01$ & $1.747 \mathrm{E}+00$ & $-1.250 \mathrm{E}-01$ & & \\
\hline & SEGe-1 & 1 & $-7.623 \mathrm{E}+02$ & $4.539 E+02$ & $-1.025 E+02$ & $1.026 \mathrm{E}+01$ & $-3.843 E-01$ \\
\hline & SEGe-1 & 2 & $-1.740 \mathrm{E}+01$ & $1.851 \mathrm{E}+00$ & $-1.279 \mathrm{E}-01$ & & \\
\hline & Summed & & $-1.259 E+01$ & $1.391 \mathrm{E}+00$ & $-1.002 \mathrm{E}-01$ & & \\
\hline \multirow[t]{11}{*}{0.65625} & SEGe-4 & 2 & $-2.284 \mathrm{E}+01$ & $3.564 \mathrm{E}+00$ & $-2.599 \mathrm{E}-01$ & & \\
\hline & SEGe-4 & 3 & $-1.439 \mathrm{E}+0 \mathrm{I}$ & $1.249 \mathrm{E}+00$ & $-9.517 \mathrm{E}-02$ & & \\
\hline & SEGe-3 & 1 & $-4.610 \mathrm{E}+02$ & $2.824 \mathrm{E}+02$ & $-6.626 \mathrm{E}+01$ & $6.902 \mathrm{E}+00$ & $-2.690 \mathrm{E}-01$ \\
\hline & SEGe-3 & 2 & $-2.031 E+01$ & $3.018 \mathrm{E}+00$ & $-2.244 \mathrm{E}-01$ & & \\
\hline & SEGe-3 & 3 & $-1.263 \mathrm{E}+03$ & $7.705 \mathrm{E}+02$ & $-1.775 \mathrm{E}+02$ & $1.814 \mathrm{E}+01$ & $-6.944 \mathrm{E}-01$ \\
\hline & SEGe-2 & 1 & $-9.370 \mathrm{E}+01$ & $5.363 \mathrm{E}+01$ & $-1.302 \mathrm{E}+01$ & $1.413 \mathrm{E}+00$ & $-5.762 \mathrm{E}-02$ \\
\hline & SEGe-2 & 2 & $-1.920 \mathrm{E}+0 \mathrm{I}$ & $2.662 \mathrm{E}+00$ & $-1.949 \mathrm{E}-01$ & & \\
\hline & SEGe-2 & 3 & $-1.985 \mathrm{E}+01$ & $2861 \mathrm{E}+00$ & $-2.108 \mathrm{E}-01$ & & \\
\hline & SEGe-I & 1 & $-2.343 \mathrm{E}+03$ & $1.450 \mathrm{E}+03$ & $-3.374 \mathrm{E}+02$ & $3.481 \mathrm{E}+0 \mathrm{I}$ & $-1.344 E+00$ \\
\hline & SEGe-1 & 2 & $-1.158 \mathrm{E}+03$ & $7.239 \mathrm{E}+02$ & $-1.709 \mathrm{E}+02$ & $1.789 \mathrm{E}+01$ & $-6.999 \mathrm{E}-01$ \\
\hline & Summed & & $-1.233 \mathrm{E}+02$ & $6.828 \mathrm{E}+01$ & $-1.522 \mathrm{E}+01$ & $1.5] 0 \mathrm{E}+00$ & $-5.626 \mathrm{E}-02$ \\
\hline \multirow[t]{11}{*}{1.56010} & SEGe-4 & 2 & $-2.284 \mathrm{E}+01$ & $3.564 \mathrm{E}+00$ & $-2.599 \mathrm{E}-01$ & & \\
\hline & SEGe-4 & 3 & $-1.439 \mathrm{E}+01$ & $1.249 \mathrm{E}+00$ & $-9.517 \mathrm{E}-02$ & & \\
\hline & SEGe-3 & 1 & $-4.610 \mathrm{E}+02$ & $2.824 \mathrm{E}+02$ & $-6.626 \mathrm{E}+01$ & $6.902 \mathrm{E}+00$ & $-2.690 \mathrm{E}-01$ \\
\hline & SEGe-3 & 2 & $-2.031 E+01$ & $3.018 \mathrm{E}+00$ & $-2.244 \mathrm{E}-01$ & & \\
\hline & SEGe-3 & 3 & $-1.263 \mathrm{E}+01$ & $7.705 \mathrm{E}+02$ & $-1.775 \mathrm{E}+02$ & $1.814 \mathrm{E}+01$ & $-6.944 \mathrm{E}-01$ \\
\hline & SEGe-2 & 1 & $-9.370 \mathrm{E}+01$ & $5.363 \mathrm{E}+01$ & $-1.302 \mathrm{E}+01$ & $1.413 \mathrm{E}+00$ & $-5.762 \mathrm{E}-02$ \\
\hline & SEGe-2 & 2 & $-1.920 \mathrm{E}+01$ & $2.660 \mathrm{E}+00$ & $-1.949 \mathrm{E}-01$ & & \\
\hline & SEGe-2 & 3 & $-1.985 \mathrm{E}+01$ & $2.861 \mathrm{E}+00$ & $-2.108 \mathrm{E}-01$ & & \\
\hline & SEGe-1 & 1 & $-2.343 \mathrm{E}+03$ & $1.450 \mathrm{E}+03$ & $-3.374 \mathrm{E}+02$ & $3.481 \mathrm{E}+01$ & $-1.344 \mathrm{E}+00$ \\
\hline & SEGe-1 & 2 & $-1.158 \mathrm{E}+03$ & $7.239 \mathrm{E}+02$ & $-1.709 \mathrm{E}+02$ & $1.789 \mathrm{E}+01$ & $-6.999 \mathrm{E}-01$ \\
\hline & Summed & & $-1.233 \mathrm{E}+02$ & $6.828 E+01$ & $-1.522 \mathrm{E}+01$ & $1.510 \mathrm{E}+00$ & $-5.626 E-02$ \\
\hline
\end{tabular}

